\title{
Articles
}

\section{The Revolutionary Martyrdom of Jonathan Robbins}

Ruth Wedgwood $\uparrow$

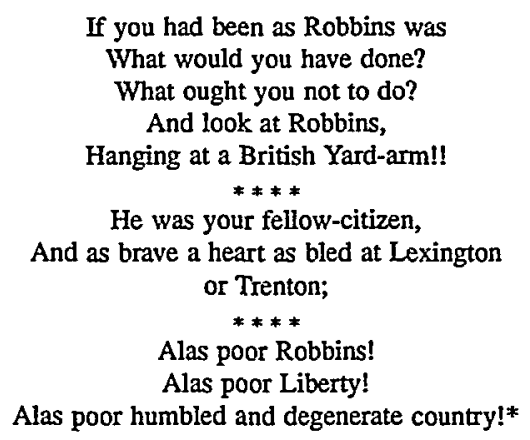

The last scene is the hardest to write, in drama and in revolution. Once political actors spurn existing allegiances, anxiety must attend. How is the revolution to close, consolidate itself and begin the normal tasks of governance? What regime of law can succeed pure politics? One way to examine these problems is in our own past, in the attitudes of our founding revolutionaries toward continuing insurgency. When the American War for Independence was completed and peace restored, did we see ourselves still as a revolutionary people, favoring structures of governance that would amplify popular voice and

$\dagger$ Associate Professor of Law, Yale Law School.

* Aurora (Philadelphia, Pa.), Sept. 3, 1799, at 2, col. 1. 
sustain resistance against authority, championing rebellion abroad and at home against any undemocratic form? Or did we regard ourselves in a more conservative mien, aloof from continuing challenge, seeing the revolution as one round only and returning to a classical ideal of government in which balance should quell upheaval, seeking our place in a settled family of nations and favoring forms of domestic governance that would enforce our commercial and public obligations under the law of nations?

This Article proposes to examine our early self-conception, as revolutionary beacon or conservative actor, through the lens of the law concerning political extradition, in particular, the case of Jonathan Robbins in 1799 and 1800, leader of a rebellion on an English ship in the midst of the Napoleonic wars. Hung in chains for his part in the shipboard mutiny, surrendered to British military justice despite his last moment claim that he was an American impressed into the British navy, Jonathan Robbins provoked a pitched battle among Americans. Attitudes toward revolution and resistance may be set by varying judgment whether rebellion's violence and disorder can be controlled and contained. By that measure, Robbins gave stridor and alarm. He was the American regaining his freedom by force used in self-defense. He was also the seaborne Jacobin, claiming liberty as excuse for the pointless slaughter of a wardroom of ship's officers.

All seemed unhinged by the fears of the 1790's. Though independence was confirmed by the peace of 1783 , and Massachusetts agrarian unrest met by the strengthened Constitution of 1787 , ratification of the infant text was succeeded by ideological innuendo and dread of seditious faction. Anglo-Federalists and Francophile Republicans worried in suspicion that European violence and ideological fever might sweep over America, and unsettle tentative constitutional compromise with leveling or monarchial extremes. The crescendo of the Jonathan Robbins affair was built upon the fears attending a decade's dissidence-citizen Genêt appealing to the people to resist Washington's declaration of neutrality, western Pennsylvania farmer-soldiers marching in resistance to federal taxation in the Whiskey Rebellion, eastern Pennsylvania farmers violently disputing taxes in Fries Rebellion, the blandishment of Republican voices seeking alliance with revolutionary France in war against the European powers, High Federalists seeking alliance with England in war against the French.

A reconstruction of the battle waged in 1799 and 1800 over Jonathan Robbins should dispel any notion that the Great Compromise of the Constitutional Convention settled the proper balance of forms of government. Some have suggested that a constitution's line of march is set in a few grand moments which recast its order and direction. We may instead conclude that a constitution, established so little by text, must be seen as constantly re-created by practice and politics, with unwritten amendments threatened at frequent junctures. A renewed choice between classical and democratic forms lay at the heart of the action. Robbins' delivery challenged American relation to the 
excesses of revolutionary violence and asked what form of government could reconcile resistance and law.

The matter at stake in Robbins was a treaty undertaking made to Great Britain to return fugitives charged with murder, promised as part of an overall settlement of British claims against the United States in the Jay Treaty of 1794. The role of the jury and the House of Representatives, as organs of popular government, was seen as crucially challenged. The treaty article might have been construed to exclude rendition when the United States had concurrent jurisdiction over the crime, preserving a jury trial and a popular political defense to the defendant. It might have been read to require implementing legislation, or to require a full jury hearing of any political defenses before rendition was ever granted. But the opposite result was reached, permitting disappointment that the revolution was forgotten and the exemplary purpose of the Bill of Rights not understood, whose luminous statements caution interpretation even when a prohibitory rule is not breached.

One might not suppose quarrels over the foreign affairs power would be central to setting domestic political structure in the aftermath of America's revolution. But at least three factors conjoined to make it so in the last decade of eighteenth century America. The treaty power allotted to President and Senate served as reminder of an alternative model of government, in which the deliberative virtues of a small collegial body are valued above immediate representation of popular political interests. The treaty power reminded that government need not be directly democratic. Too, ideological polarization in Europe was at its height; alliance or "weighted" neutrality was seen as choice of philosophy and tenor of government. With so little of American government settled by rule, with only practice and philosophy to harmonize rival powers, a foreign orbit seemed likely to distort domestic debate. The dangers seemed all the more acute when the orbit could be chosen by an aristocratic Senate and monocrat President.

The third magnifier was history. In the English constitutional history available to American debaters, and in their own revolutionary experience, the foreign affairs power had posed a continuing danger to domestic entitlements-the urgent claims of foreign safety used as reason to assess new taxes or demands of supply without the consent of directly elected representatives. In the memory of Republicans and Federalists, conflicts between prerogative claims in foreign affairs and the popular control of government were what ripened into revolutions. In the Robbins case, the matter would be posed in its most acute form, with treaty power disposing of very liberty.

We will see two models of governance competing for American allegiance. In the Republican model, the power of the Executive and its privy Senate must always be restrained. The popular voice of the House of Representatives must be allowed to check foreign undertakings. Faithful execution of "the law" is a narrow constitutional power, limiting the Presidency to the law as given by 
Congress, excluding Presidential execution of treaty undertakings or of the unwritten law of nations where they affect domestic enjoyments, unless the House has acceded. Restrictions on the exercise of personal liberty or use of property must always be apnroved by immediate legislative authorization and the assaying check of a jury.

The competing model of Federalists takes heed of popular weaknesses. With the Constitution's new resolve to cure earlier incapacities, sovereign America's position in foreign affairs should drive constitutional construction. Executive power must be permitted to act efficaciously. Treaties made by the President and Senate must be counted fully as law. The Presidency must have authority to act upon treaty promises, and perhaps even upon the rules of the unwritten law of nations - even when the Presidential action occurs on-shore and affects citizens. "Law" is constituted from several sources, legislation only one among them, and the President's constitutional duty of faithful execution endows him with a large reserve for action. Though the Congress, acting by supermajority, may be able to forbid Presidential action that affects domestic entitlements, silence and inactivity is not a bar. The President may even seek to act through executive warrants and commissioners, spurning the ordinary jurisdiction of courts and juries, to implement international undertakings in domestic settings unchecked by any other branch.

Though the mixture of substance and process will be troubling to formalist lawyers, the quarrel of century's close on the balance of power among constitutional branches interleaved the debate on America's revolutionary role in the world. In Jeffersonian eyes, how to distribute American foreign affairs power depended at least in part on political purpose, whether to enter into the settled legal relations of commercially ambitious nations, or to advance France's march to freedom. Ideological posture helped to seat the foreign affairs power through the belief that each branch of government had its own natural temper. Can the Executive act unilaterally to fulfill treaty obligations or to serve the law of nations even where domestic liberty is affected? Can federal judges act in aid of the Executive's Article II powers as a magistracy out of doors or with jurisdiction created by treaty or Article III directly, even without Congressional authorization? And crucially, may the United States extend the treaty power to consign its own citizens to the criminal system of a foreign state that lacks the protection of jury trials? In Republican gaze, efficacy of action in foreign affairs was ill-sought if the native pitch of a strong Executive was to ally with monarchial power. The constitutional claims advanced in the Robbins case were more than coincidentally connected to a decision that aided the maintenance of British naval discipline in her fight against revolutionary France. Strong Executive power seemed the cousin of the ancien régime, and domestic governance favoring popular voice, the homologue of liberal revolution.

Through new emigrants and outward gaze, a country that traces its identity to an act of violent resistance is bound to define and redefine itself against 
other conflicts in the world. With eyes fixed on Philadelphia, we have not examined how the continuing French upheaval altered American politics and constitutionalism - taking too lightly the once vivant ideas of classical thought, in which well-tempered government meant balancing capacities or estates of men as much as separating technical functions, misunderstanding the limits of democracy familiar to the founders, not seeing how the French example might cause Americans to measure their constitution anew against French égalité, skimming past how our founding generation in the second blush of national youth came to understand the problems of violence and change. The trajectory of American Constitutionalism cannot be mapped in isolation.

The Robbins affair will offer understanding of the degrees of freedom left by the written constitution to American political actors: radically different regimes of power and authority could be fit to the document's few rules. In its unexampled fear of the President's power to execute law (and sailors), the Robbins affair also may yield an important clue to the source of our majoritarian positivism, to our bluntly narrowed understanding of possible sources of law. One might associate natural law with revolutionary self-conception, for natural law allows one to measure the justice of existing institutions. Why, then, does the law of nature and nations meet a hard death in the nineteenth century as a source of entitlement to act? ${ }^{1}$ Why even revolutionaries may become public positivists, looking for law only in the will of the legislator, is answered in the Robbins affair. If it is once admitted that law consists of more than legislative edict, the power of mediately elected Presidents and unelected judges is many times magnified. The seventeenth century battle of English parliamentarians to confine the Crown's prerogative finds counterpart in the caution of American democratic-republicans-who drew confidently on the law of nature and nations to justify revolution and to provide rules of decision in nascent independence, but who came to realize that counting these rules as domestic law could shift power from the more popular branches of government. American judges are sometimes shy to admit they make law, or find law in sources other than legislation; rules of reception are acted upon in quiet voice, with fictive talk about intent. It is not only institutional courtesy restraining judicial speech, for legislators fully understand many of the rules of construction and assimilation in courts' law-making. Rather, judicial tact may rellect the fear that a rhetoric broadly construing the sources of "law" would unacceptably (to some) enhance Presidential power. The power of faithful execution may uneasily border prerogative. ${ }^{2}$

1. The unwritten law of nature and nations will supply rules of decision where a matter is already committed for action, but it will not often be a separate head of power.

2. Courts may be tamed by requiring affirmative legislative grants of jurisdiction, but Presidential power is not so easily conditioned. The constitutional critic might conclude that Congress' twentieth century strategy toward the Presidency has mimicked Congress' treatment of the courts. Congress expressly delegates authority to each coordinate branch in avoidance of the question of original constitutional vesting. The nearly 
Constitutional reproof in the Robbins affair was to be delivered by Adams' close escape from censure and impeachment, and the Federalists' defeat in the 1800 election. John Adams' misbegotten personal fortune-the unlikable man denounced for pomposity, monarchialism, and designs on the American demos, taken to task for attitudes often shared by the inviolable Washington, stricken by the success of Republican attacks that bore little relation to his actual part in the Robbins matter-was Atropos' warning that any assertion of Executive prerogative, any Executive action lacking the warrant of House approval, might excite popular resistance. The few truncated accountings of the Robbins affair have not discerned what were Adams' actual demerits and extenuations in this case of alleged interference with the independence of the judiciary and disregard of the domain of the House, nor have they measured Adams' involvement against his own revolutionary youth, when he defended American sailors charged for resisting British impressment. Nor have constitutional historians paid any mind to the extraordinary theory of Executive power endorsed by Congressman John Marshall, in his rescue of Adàms from the hands of House Republicans. Marshall placed a law-making faculty in the Presidency startling to modern ears, allowing the President to act without the filtration of courts even in matters of domestic liberty. ${ }^{3}$ Marshall's bravura was to be celebrated over the course of the nineteenth century.

The dispute of Executive power in foreign affairs in our own century looks back without remembrance. That the President is "the sole organ of the nation in its external relations," famous as the nostrum of United States v. CurtissWright Export Co., ${ }^{4}$ was plucked by Justice Sutherland from Congressman Marshall's defense in the Robbins affair. A reconstruction of the occasion for Marshall's address will discomfit, no matter one's contemporary views. Executive power's critics have lethely overlooked the ambitious, even radical, charac-

complete assignment of Article III power by the modern Judiciary Acts has tabled the question looming in the early nineteenth century-whether the federal courts have the right to exercise full Article III power even without authorizing legislation. So too, many twentieth century statutes delegate foreign affairs powers to the Presidency that Presidents may have thought they already had under Article II. It is as if Congress has to concede some decisions are by nature fitted to Executive discretion, unsuited to the broader categorizing of legislation, yet wishes to reserve a potential veto on Presidential action, to be overcome only should the President summon all of his Article II courage.

3. John Marshall's strong nationalism, his rule of efficacy for the Constitution, with implied powers necessary for government in a fractious world, finds precursor in his work as a new-minted Federalist Congressman. Representative Marshall's defense of Presidential power in foreign affairs and of John Adams' role in the Robbins case immediately precedes his elevation to the Cabinet and to the Supreme Court, and one may indulge a nonviolent presumption that the two events were connected. Marshall's later encomium in McCulloch v. Maryland, 17 U.S. (4 Wheat.) 316 (1819), to the full flush of necessary and proper legislative powers, lest important federal ends be frustrated by crabbed means, has its executive counterpart in Jonathan Robbins. Means of implementation must be deduced from the necessities of the case, and the ends of power are not to be frustrated by "defects" and gaps in the law. Marshall's defense of effective Executive power in the Robbins affair, though delivered by a Congressman, was to be awarded constitutional place in the Appendix of Wheaton's Supreme Court opinions, see 18 U.S. (5 Wheat.) app. (1820), in lapidary pairing with $\mathrm{McC}$ ulloch.

4. 299 U.S. 304, 319 (1936). 
ter of John Marshall's claim for the Presidency. Yet Executive power's friends must view uneasily the aftermath of the Robbins affair, its constitutional high winds helping to topple Adams from power. The Robbins affair remains signal of danger and overreaching, evidence of our indecision about the Executive's capacity for action. For true emergency we fear its absence, even as we are jealous democrats. How Robbins turned out, and why, will justify the caution of some other Presidents in pursuing Article II to its limits.

\section{THE HERMIONE AND JONATHAN ROBBINS}

The Robbins imbroglio began with a rebellion on His Majesty's armed frigate Hermione..$^{5}$ The mutiny of September 22, 1797, was notorious to later British naval historians for the tyranny of the captain whose command was overthrown, and the excessive violence of the mutineers. ${ }^{6}$ British naval historians are not inclined to endorse a right of revolution in the governance of ships, yet the abject condition of the Hermione sailors led one chronicler to suggest the uprising was near excusable, had the rebels not consumed so many helpless victims. $^{7}$

The Hermione was a 32 gun frigate assigned to the British West Indies command under Vice Admiral Hyde Parker, fighting revolutionary France and her Spanish ally Charles IV. Hugh Pigot, captain of the Hermione since February 1797, had some virtues of a daring commander. In one foray on April 20, 1797, Pigot commanded five British ships to Port-au-Paix, Haiti, ran manned

5. In classical mythology also, Hermione's fate was bound with violence. Hermione was daughter of Menelaus and Helen, offered by her father to Orestes. The Greeks could succeed in the war against Troy only after Achilles' son Neoptolemus maneuvered the Trojan Horse, and for this victory, Menelaus retrothed Hermione to Neoptolemus. At Delphi, Orestes killed Neoptolemus in revenge-inciting a crowd with the slander that Neoptolemus had come to rob the shrine. THE ODYSSEY 3.188-89, 4.5, 11.508-09; SOPHOCLES, PHILOCTETES .114, .345; EURIPIDES, ANDROMACHE .964-70, .1085-1165.

6. See 3 I. SCHOMBERG, THE NAVAL CHRONOLOGY; OR, AN HISTORICAL SUMMARY OF NAVAL AND MARITME EVENTS 75-77, 340-41, 510, 520 (London 1815); 2 E. BRENTON, NAVAL HISTORY OF GREAT BRTtAIN 435-37 (London 1st ed. 1823); 1 id. at 428 (London 2d ed. 1837); 1 C. YONGE, THE HISTORY OF THE BRITISH NAVY 536-42 (London 1863); 2 W. JAMES, THE NAVAL HISTORY OF GREAT BRTTAIN 102-04, $360-66$ (1837). Modern popular accounts of the shipboard events are given in D. POPE, THE BLACK SHIP (1964); J. DUGAN, THE GREAT MUTINY 393-96 (1965); and Thompson, Saga of a Mutineer, 53 MARINER's MIRROR 171 (1967). Pope includes a useful bibliography of British Public Record Office materials.

There are skeletal accounts of the Robbins incident in F. WHARTON, STATE TRIALS OF THE UNTED STATES DURING THE ADMINISTRATIONS OF WASHINGTON AND ADAMS (Philadelphia 1849); D. STEWART, THE OPPOSITION PRESS OF THE FEDERALIST PERIOD 242-47 (1969); and Cress, The Jonathan Robbins Incident: Extradition and the Separation of Powers in the Adams Administration, 16 ESSEX HIST. COLL. 99 (1975).

7. "If the Ali Pacha of the ship had been the sole victim of their rage," commented naval historian William James, "the public indignation might have been appeased, the instant the daily practices of the tyrant became known; but the indiscriminate slaughter of their officers, even to the young clerk and midshipman, gave a shock to public feeling, which vibrates even yet when the subject is touched upon." 2 W. JAMES, .supra note 6, at 103. Writing as a Captain in service in the Royal Navy, even Edward Pelham Brenton softened his denunciation of the mutineers in his 1837 edition: "Let our officers be warned by the fatal beacon! Let them recollect that seamen have the feelings of men . . . Excessive zeal often ends in tyranny, and tyranny is the parent of rebellion." 1 E. BRENTON, supra note 6 , at 428 (2d ed. 1837). 
boats into the harbor under darkness while continuing with his squadron offshore to distract the French, and successfully seized nine French vessels-one ship, three brigs, three schooners, and two sloops. In his official letter to the Admiralty describing this success, Pigot omitted the names of the officers and men present on the adventure, an omission regretted by later naval commentators and harbinger of his disregard for his crew. ${ }^{8}$

Pigot's shipboard discipline was seen as harsh and highly arbitrary. In a prior command he went so far as to flog the captain of an American merchantman, William Jessup, for disputing his right to visit and search, for which Pigot

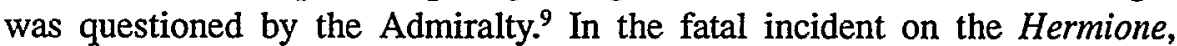
according to Brenton, Pigot ordered his sailors down from the mizzen-topsailyard and threatened to flog the slowest.

The poor fellows well knowing that he would keep his word (and though the lot would naturally fall on the outermost, and consequently the most active), each resolved at any risk to escape from punishment[.] [T] wo of them, who from their position could not reach the top-mastrigging, made a spring to get over their comrades within them; they missed their hold, fell on the quarter-deck, and were both killed. This being reported to the Captain, he is said to have made answer, "Throw the lubbers overboard."10

The day after the lubbers were dispatched, the crew mutinied, wounding Captain Pigot on deck with a tomahawk and following him below in a foursome. Pigot was bayoneted in his cabin and flung through a porthole into the sea. The crew also killed three lieutenants, the purser, the ship's doctor, a clerk, a midshipman, the boatswain, and a lieutenant of marines, some of whom were unlikely opponents lacking involvement in Pigot's excesses as captain. The mutineers, said a nineteenth century commentator, acted "in a most cruel and savage manner, dragging [victims] from their beds, cutting and hacking them with tomahawks and other weapons, and thrusting many overboard whilst yet alive."11 The sailors took the Hermione into the port of La Guaira, in the Spanish Main, now Venezuela, and turned her over to Spanish officials in exchange for a pledge not to return them to the British. In a report of the local Spanish governor, the mutineers were said to have declared they rebelled from the "Necessity of liberating themselves from the severe treatment and chastise-

8. Pigot's report is preserved at the British Public Record Office. See Letter of Hugh Pigot to Sir Hyde Parker (Apr. 21, 1797), in "IN-LETTERS," ADMIRAL's DisPaTCHES, JAMAICA (British Public Record Office, Adm. 1/248).

9. See Instruction of Lord Grenville to British Minister Robert Liston (Oct. 7, 1796), in INSTRUCTIONS TO THE BRTISH MINISTERS TO THE UNTTED STATES 1791-1812, 3 ANN. REP. AM. HIST. ASS'N 122 \& n.56 (B. Mayo ed. 1936), reprinted as H.R. Doc. No. 13, 75th Cong., 1st Sess. (1941). The American Minister in London, Rufus King, was instructed to protest "the tyrannical and inhuman conduct of Captain Pigot." Id. at 122 n. 56 .

10. 2 E. BRENTON, supra note 6 , at 436 (1st ed. 1823).

11. 3 I. SCHOMBERG, supra note 6 , at 76 . 
ment which they met with from the Captain and certain of the Officers."12

The British fleet was already unsettled, with other recent mutinies in the fleets at Spithead and the Nore. ${ }^{13}$ Loss of the Hermione to the Spanish antagonist was especially galling to the British, yet more so when she was renamed Santa Cecilia and became a highly successful privateer, attacking British merchant shipping throughout the Caribbean. For the next two years Britain tried to recover the ship and finally did so in a chancy harbor assault by the frigate Surprise, for which Edward Hamilton was knighted and painted into a mural in Greenwich Hospital, London. ${ }^{14}$ The violence of the Hermione mutiny, wished-for deterrence against further unrest, and the disloyal surrender of the ship to the Spanish enemy led the British Admiralty to hunt down Hermione sailors without remission. Brenton reports that "Justice speedily overtook them; many were captured in Spanish vessels, or recognized in English ones, and brought to trial. The Author witnessed the execution of some at Portsmouth, others were hanged in the ports of St. Domingo, and the remains of many are suspended on gibbets erected on the sandy keep at the entrance of Port Royal harbour in the island of Jamaica."15 Upon her recapture, the Hermione became the Retribution. ${ }^{16}$

The United States was drawn into the Hermione affair by the wanderings of the crew into United States ports, ${ }^{17}$ and this is the subject of our essay. In March 1798, three crew members from the Hermione, including one William Brigstock, were to be arrested in Perth Amboy harbor in New Jersey, tried for piracy in an American federal circuit court before Justice Samuel Chase, and acquitted. Partisanship and national self-regard did not weigh so heavily on this first incident, perhaps because it was over quickly and dispatched liberally by the jury. In February 1799 another man alleged to be a Hermione sailor was arrested in Charleston, South Carolina (the largest American port in the South) from on board an American ship, the Tanner's Delight. He used the name of Nathan or Jonathan Robbins, but was alleged to be Thomas Nash, the bosun's mate of the Hermione.

The decision to return Robbins to British military justice led to a legal and political contretemps in which Republicans denounced the monarchial tendencies of Federalists and overweening Executive power, while Federalists saw proof of the dangerous zeal of democratic Republicans. Jefferson would com-

12. Letter from Don Pedro Carbonell, Captain General of Caracas, to Sir Hyde Parker (Dec. 7, 1797), translation sent as Attachment to Letter from Sir Hyde Parker to the Admiraity (Feb. 4, 1798), in "IN-LETTERS," ADMIRAL's DISPATCHES, JAMAICA (British Public Record Office, Adm. 1/248).

13. In this matter of timing, as in things anagogical, the Robbins incident recalls Melville's story.

14. 1 E. BRENTON, supra note 6, at 463-64 (2d ed. 1837); C. YONGE, supra note 6, at 538-42.

15. 2 E. BRENTON, supra note 6, at 437 (1st ed. 1823).

16. 1 E. BRENTON, supra note 6 , at $463-64$ (2d ed. 1837).

17. Vice Admiral Sir Hyde Parker fretted: "those atrocious Villains . . . are dispersing themselves to different parts, and unless sound Policy, induces the United States of America to assert their powers in apprehending these Criminals, I much fear they will escape." See Letter from Sir Hyde Parker to the Admiralty (Feb. 4, 1798), supra note 12. 
ment to Charles Pinckney, "I think no one circumstance since the establishment of our government has affected the popular mind more."18 Adams, in turn, would later speak bitterly of the terrorism afoot in the 1790's-in domestic events such as the Whiskey and Fries Rebellions-and in the attempt to impeach him over the Jonathan Robbins affair. ${ }^{19}$

Before reconstructing operatic history, it is well to allow a mise-en-scène. In particular, for the story of Jonathan Robbins to be viewed with larger vision than was immediately available to its partisan participants, and because we wish to see it as lawyers and constitutional historians, we should look briefly at the law's treatment of piracy and uprisings at sea, and the early constitutional debate on how to reconcile treaty power with domestic liberties and democratic legislature.

\section{THE High SEAS AND UNIVERSAL JURISDICTION}

How the law would treat a shipboard mutiny concerns the basis of jurisdiction to prescribe, apprehend, adjudicate, and enforce. The independence of nations was classically seen as giving authority to each state to prescribe for those present within its territory, and for those who were its subjects or citizens. Ideally this division of prescriptive jurisdiction would allow each political community to regulate the conduct of those most immediately affecting its welfare, and would present each human actor with a consistent set of obligations. (Consistency and possibility, as Lon Fuller has reiterated in our age, are prerequisite to conceiving of a set of commands as legal.) Limiting prescriptive jurisdiction also was to serve the purpose of social peace, an anti-barratry rule to keep states from intermeddling where their own interests were not at stake.

Fitting a jurisdictional system to the sea depends on how the sea is regarded. Hugo Grotius and John Selden fought their seventeenth century duel over the idea of territory in the sea, Grotius arguing for open seas in Mare Liberum to ease navigation for the Dutch East India Company en route to the East through waters claimed by the Spanish and Portuguese, and Selden arguing for closed seas, Mare Clausum, in support of Britain's claim to the "narrow seas" desired for fishing and security. ${ }^{20} \mathrm{By}$ the eighteenth century, it was widely

18. Letter from Thomas Jefferson to Charles Pinckney (Oct. 29, 1799), in JEFFERSON PAPERS, SERIES 1 (Library of Congress microfilm edition, roll 21, frames 18078-79); also in 7 THE WRITINGS OF THOMAS JEFFERSON 397 (P. Ford ed. 1896).

19. See Letter from John Adams to Thomas Jefferson (June 30, 1813), in 2 THE ADAMS-JEFFERSON LETTERS 346-48 (L. Cappon ed. 1959 \& reprint 1988).

20. H. GROTIUS, MARE LIBERUM [THE FREEDOM OF THE SEAS] (Amsterdam 1609; R. Magoffin trans. Carnegie Endowment for Int'1 Peace 1916); J. SELDEN, MARE ClAUSUM [OF THE DOMINION, OR, OWNERSHIP OF THE SEA] (London 1635; M. Nedham trans. London 1652 \& reprint 1972). Selden's theory of exclusion was continued by Sir Philip Medows in OBSERVATIONS CONCERNING THE DOMINION AND SOVEREIGNTY OF THE SEAS (London 1689). England's territorial claim at its greatest included the Irish Sea, the North Sea, St. George's Channel, and soi-disant the English Channel. See W.E. HaLL, A TREATISE ON INTERNATIONAL LAW 144-47 (4th ed. Oxford 1895). 
accepted that nations could not have exclusive territory in the sea other than the confined limits of a coastal band ${ }^{21}$ or in enclosed waters. With the high seas accepted as a tenancy in common, prescriptive and other forms of jurisdiction remained uncertain. Jurisdiction to regulate shipboard conduct could be singular or concurrent, determined by the nationality of the ship, the actor, or the victim, or by the internationality of the sea beneath the hull. Nor was nationality clear; the basis for ascribing human nationality may be birthplace, genealogical descent, prior oath-taking, or current profession of allegiance. Ships also can change (and feign) nationality by conveyance of title or by hoisted flag, ${ }^{22}$ complicating any claim of exclusive jurisdiction. Concurrent jurisdiction had the considerable virtue of permitting any nation catching an offender to act upon his wrongs - without resolving the fine points of a theory of exclusive jurisdiction, and without facing the political, moral, and legal concerns of aiding a foreign system of justice.

The most feared act at sea was piracy, troubling because of its indiscriminate violence, and its commission far beyond any nation's effective reach. Piracy, instructed Lord Coke, was robbery on the sea. ${ }^{23}$ It bore some resemblance to the permitted practice of privateering. ${ }^{24}$ But privateers were closely limited by the law of nations. A privateer had to have a recognized nation-state sponsor whose martial purpose was advanced by depriving an enemy of supplies and revenue from shipping, ${ }^{25}$ and could use force only for capture; hostages could not be taken, nor noncombatants slain. A privateer had to discriminate between contraband and permissible cargo, and neutral and belligerent ships, and had to submit captures to the "neutral and detached magistracy" of the prize courts before property could be sold. Much of America's early foreign policy dwelt upon our rights as a neutral under this lex non scripta. ${ }^{26}$

21. The range of cannon shot as a limit for coastal waters was advocated by Cornelius van Bynkershoek in DE DOMIINIO MARIS DISSERTATIO (2d ed. Leyden 1744); see also C. BYNKERSHOEK, TREATISE ON THE LAW OF WAR 59 (P. Du Ponceau ed. Philadelphia 1810). The United States accepted this limit in 1793. See Letter from Thomas Jefferson to French Minister Charles Genêt (Nov. 8, 1793), in 6 THE WRITINGS OF THOMAS JEFFERSON, supra note 18, at 440; Letter from Thomas Jefferson to British Minister George Hammond (Nov. 8, 1793), in 6 id. at 441.

22. In later slave trade and prize cases, courts would sometimes look behind the form of documents and attempt to find the "real" nationality of the ship to determine application of national laws on slave trade and rules of neutrality.

23. 3 E. COKE, INSTITUTES OF THE LAWS OF ENGLAND, ch. 49, at 113 (London 1644).

24. In an early harnessing of private motive for public purpose, privateers were permitted to take merchant quarry in time of war, seeking to prevent belligerent states from gaining revenue through carriage of goods and to prevent neutrals from shipping war matériel to belligerents.

25. There was long debate whether non-contraband enemy goods were subject to seizure on board neutral vessels, and whether supplies such as food should count as contraband.

26. Caseload may influence jurisprudential view. The nineteenth century American Supreme Court's docket of prize cases likely helped sustain the Court's belief in an unwritten law of nations proceeding from reason as well as custom and consent-and pace The Paquete Habana, 175 U.S. 677 (1900), to bolster the Supreme Court's resistance to any casual violation of the law of nations by American executive officials or legislators. Quite unlike Brainerd Currie's modern conflicts forum, a prize court was not to favor local policy interests of the forum state, rather to function almost as if it were a chamber of an international tribunal. A prize court sat as a "court of the law of nations," as Justice Story reminded in La Jeune Eugenie, 
Though privateering would be challenged as a practice close to piracy, ${ }^{27}$ it was not blemished in the public mind by the ruthlessness and indiscriminacy of pirates who used violence for private purpose without rules or restriction.

The difficulty of tracking piratical vessels through the oceans gave rise to one of the Enlightenment's few working doctrines of universal jurisdiction. Though territory and nationality fixed the general limits of a state's jurisdiction to proscribe or adjudicate crimes, pirates were deemed hostes humani generis, the enemy of all. The law of nations permitted punishment of any pirate by any country even if the particular piratical acts had not injured its ships or citizens. ${ }^{28}$ With the Barbary pirates of the 1790's, this doctrine was of keen interest to American masters.

Beyond piracy as hostes humani generis, there was the possibility of a second category of universal crime. A lingering view saw the law of nations as jus gentium as well as jus inter gentes, a law governing domestic life as much as international relations. Municipal law could be seen as mere publication and specification of penalty for a code of conduct common to nations. ${ }^{29}$ In such a view, it would not subject a person to inconsistent obligations nor

26F. Cas. 832, 841 (C.C.D. Mass. 1822) (No. 15,551); see also The Maria, 1 Robinson's English Admiralty Reports 340, 350 (High Court of Admiralty 1799) (Scott, J.) ("It is the duty of the person who sits here to determine this question exactly as he would . . . if sitting at Stockholm.") (emphasis in original); H. WHEATON, ElEMENTS OF INTERNATIONAL LAW, pt. 4, ch. 2, \& 15, at 261-62 (Philadelphia 1836); H. HALLECK, INTERNATIONAL LAW, ch. 31, $\S 19$, at 766-58 (San Francisco 1861). The sense that a universal law of nations was real and compelling also may be seen in the nineteenth century Supreme Court's early regard for lex mercatoria, see Swift v. Tyson, 41 U.S. (16 Pet.) 1 (1842), and infra note 426, and in its flirtation with a federal common law of crime, see infra note 33. (Diversity jurisdiction enforced a substantive commercial law conforming to the law of nations. The federal common law of crimes enforced international rules such as the inviolability of ambassadors.)

The decline of a prize docket came with changing maritime rules and the professionalization of American naval warfare. Though prizes could be taken by government naval vessels, most of the early prize docket arose from seizures by privateers, whose crewmen found the prospective share of prize money a major incentive for performance. But, following the Crimean War, the 1856 Declaration of Paris forbade privateering among the signatory nations, see T. BOWLES, THE DECLARATION OF PARIS OF 1856 (1900); $7 \mathrm{~J}$. MOORE, A DIGEST OF INTERNATTONAL LAW 561 (1906); 2 L. OPPENHEIM, INTERNATIONAL LAW 583 (2d ed. 1912). The United States initially resisted the Paris rule because it lacked a large navy and depended on private seizures to enforce the rules of neutrality, but the United States concurred in the substance of the Paris ban by the late nineteenth century. With the loss of this naval form of posse comitatus, the Supreme Court's prize docket declined and the Supreme Court had less occasion to see itself as an international fiduciary.

27. See Dispute XXXV, Question: Is Privateering Justifiable?, in PRESIDENT DWIGHT's DECISIONS OF QUESTIONS DISCUSSED BY THE SENIOR CLASS IN YALE COLLEGE IN 1813 AND 1814, at 289 (T. Dwight, Jr. ed. 1823).

28. 3 E. COKE, supra note 23, ch. 49, at 113; cf. C. BYNKERSHOEK, QUAESTIONUM JURIS PUBLICI LIBRI DUO, bk. 1, ch. 17 (Leyden 1737); T. RUTHERFORTH, INSTTTUTES OF NATURAL LAW, bk. 2, ch. 9 (Cambridge, England 1756).

29. This hope of a universal jurisprudence lingers from Enlightenment optimism: that reason might succeed to the place once held by revelation, and universal Christendom yield to a common rationality. Augustine had the last laugh, of course, when willfulness reasserted itself in nineteenth century positivism. But in the interim, the cosmopolitan writers on the law of nature and nations addressed questions of domestic governance as well as inter-state relations. See, e.g., S. PUFENDORF, DE JURE NATURAE ET GENTIUM LIBRI OCTO [ON THE LAW OF NATURE AND NATIONS] (Lund 1684; B. Kennett trans. Oxford 1703); J. BURLAMAQUI, PRINCIPES DU DROTT NATUREL ET POLITIQUE [ON NATURAL LAW] (Geneva 1747; T. Nugent trans. Oxford 1748). 
surprise him in his primary conduct were any nation to punish even land-locked crime under the common standards of this law of nations. ${ }^{30}$ We will see a view (in men so diverse as James Wilson and Charles Lee) that any nation might be able to punish common crimes at sea-even where the conduct did not occur on a flag vessel nor involve nationals as offenders or victims, and had no immediate impact on the interests of the nation.

One could also see ordinary crimes at sea as part of an international lex mercatoria or lex maritima, a law merchant or law maritime designed to provide consistent rules of conduct for men who sailed with shipmates of many nationalities. If this lex mercatoria or maritima is recognized by all nations, the individual would not lack notice of applicable standards. The crimes can be punished by any government, not because the offender poses a universal danger, but for mere convenience.

Revolution at sea was a puzzling fit. Acts of rebellion against shipboard discipline and a crew's seizure of a ship from its officers can be piracy in the special sense of a country's national law. But it was not clear that shipboard revolution constituted piracy within the traditional theory of universal jurisdiction under the law of nations. Common interest may obtain; the example of rebellion against shipboard hierarchy may endanger other captains; a former mutineer can sow the seeds of resistance wherever he is mustered. Yet a mutinous sailor may revert to customary obedience in a better-managed crew; ${ }^{31}$ he may have acted from a public rather than private meretricious motive; the stability of ships, like nations, can depend on wise government. How to regard mutinous sailors also exposed a new fault line of world law. Should one regard the law of nations as a code to conserve existing regimes and governments and enforce obligations among them? Or should there instead be a transforming law of nations that favors the overthrow of unjust regimes? The debates of our own time are anticipated in the 1790's, when France's National Convention declared universal war on the ancien régime, proclaiming a new international law of violence and liberation. ${ }^{32}$

30. As late as 1840, Chief Justice Taney would suggest in Holmes v. Jennison, 39 U.S. (14 Pet.) 540, 568-69, that American states were free to punish crimes committed abroad by offenders who had "com[e] among them," even when the fugitive had no relation to the United States at the time of the crime.

31. In the British fleet, mutinies were sometimes akin to job actions or wildcat strikes. The crews of 113 ships at Spithead and the Nore declined to work in 1797, asking for greater pay and provisions, "more equal distribution of prize money; and the displacement of several obnoxious officers." The demands "created the most alarming apprehension in the British ministry," reported the Philadelphia Aurora, but "were complied with in their fullest extent" and a pardon for the mutineers issued by the King. Aurora (Philadelphia, Pa.), June 13, 1797, at 2, col. 4; see id., June 17, 1797, at 2, cols. 3-4 (reprinting sailors' petition to Lord Commissioners of Admiralty). The pardon was allowed despite the threatened use of violence against officers, even after the crews' display of "ropes, in terrorem, at the fore yard arm." Id., June 20, 1797, at 2, col. 2.

32. Decree of the National Convention (Nov. 19, 1792), in Le Patriote François (Paris), Nov. 20, 1792, at 581 , col. 2 ('La convention nationale déclare, au nom de la nation française, qu'elle accordera fraternité et secours à tous les peuples qui voudront recouvrer leur liberté, et charge le pouvoir exécutif de donner aux généraux les ordres nécessaires pour porter secours à ces peuples, et défendre les citoyens qui auroient 
In American law, the view persisted until surprisingly late, that acts against the law of nations and common crimes on the high seas could be punished even without specific Congressional enactment. ${ }^{33}$ But the punishment of piracy and

été vexés, ou qui pourroient l'être pour la cause de la liberte."); also in 53 ARCHIVES PARLEMENTAIRES DE 1787 À 1860, at 474 (Paris 1898) (with minor textual variations), and in National Gazette (Philadelphia, Pa.), Feb. 16, 1793, at 125, col. 2 ("The national convention declare, in the name of the French nation, that they will grant fraternity and assistance to every people who wish to procure liberty and they charge the executive power to send orders to the generals to give assistance to such people, and to defend citizens who have suffered or are now suffering in the cause of liberty."). Robbins' nautical blow to Pigotian tyranny, disrupting the naval maneuvers of the counter-revolution, showed a universal law of nations under siege, favored for the sake of commerce, riven on the claim of freedom.

33. It is frequently supposed that the federal common law of crimes expired without testament in United States v. Hudson \& Goodwin, 11 U.S. (7 Cranch) 32 (1812). But this disguises a more complicated story. In the late eighteenth century, individuals were prosecuted in federal court for nonstatutory offenses under several different theories: criminal acts could be defined and sanctioned by the law of nations, American treaty law, the Constitution, a common law adapted to protect federal functions, or a common law adapted to govern exclusive federal preserves such as the high seas. Charges often relied, in duplicitous profusion, on more than one nonstatutory source of law. See Henfield's Case, 11 F. Cas. 1099 (C.C.D. Pa. 1793) (No. 6,360 ) (privateering violated neutrality under the law of nations, treaties with Great Britain, Netherlands, and Prussia, the Constitution and "the peace and dignity of the said United States"); United States v. Ravara, 2 U.S. (2 Dall.) 297, 27 F. Cas. 713 (C.C.D. Pa. 1793) (No. 16,122) (extortion of British minister by Genoa consul violated common law, apparently cognizable in federal court because of status of defendant or victim); United States v. Smith, 27 F. Cas. 1147 (C.C.D. Mass. 179[7]) (No. 16,323) (counterfeiting bills of the Bank of the United States was case "arising under" the laws of United States "for those bills were made in virtue thereof, though there was no statute describing or punishing the offense of counterfeiting them"; counterfeiting punishable as "a contempt of and misdemeanor against the United States"); United States v. Worrall, 2 U.S. (2 Dall.) 384, 395, 28 F. Cas. 774, 779 (C.C.D. Pa. 1798) (No. 16,766) (offering bribe to Commissioner of Revenue, though not prohibited by 1790 Crimes Act, was indicted as "contempt of the laws and constitution of the said United States . . . and against the peace and dignity of the said United States" [emphasis omitted]; found by Justice Peters to be common law offense "cognizable under the[ ] authority" of the United States); Williams' Case, 29 F. Cas. 1330 (C.C.D. Conn. 1799) (No. 17,708) (privateer indicted for violating Jay Treaty, and, perhaps, 1794 Neutrality Act); see also Letter of Charles Lee to Timothy Pickering (Jan. 26, 1797), in 1 OP. ATT'Y GEN. 68 (Benjamin Hall ed. 1852) (of William Jones who violated territorial rights of Spain by seizing fugitive slaves in Florida: "The constitution gives to Congress, in express words, the power of passing a law for punishing a violation of territorial rights, it being an offence against the law of nations .... Congress has passed no act yet upon the subject, and Jones and his associates are liable to be prosecuted in our courts at common law for the misdemeanor; and if convicted, to be fined and imprisoned. The common law has adopted the law of nations in its fullest extent, and made it a part of the law of the land.").

Hudson \& Goodwin polished off the category of "federal function" common law offenses, in the continuing worry over seditious libel prosecutions. (Republicans had proved as prideful and retributive as Federalists, bringing common law libel prosecutions in federal court long after the 1798 seditious libel statute expired.) Even after Hudson \& Goodwin, Justice Story suggested on circuit that admiralty and maritime jurisdiction should be regarded differently, see United States v. Coolidge, 25 F. Cas. 619 (C.C.D. Mass. 1813) (No. 14,857) (Story, J.). Attorney General Richard Rush and Chief Justice Marshall declined Story's invitation, see United States v. Coolidge, 14 U.S. (1 Wheat.) 415 (1816); cf. United States v. Bevans, 16 U.S. (3 Wheat.) 336 (1818); United States v. Wiltberger, 18 U.S. (5 Wheat.) 76 (1820), yet constitutional publicists continued to offer the view that nonstatutory offenses under the law of nations were a salvageable category. If foreign affairs power was peculiarly reserved to the federal government, the federal courts' lawmaking in this category did no violence to states' reserved powers. See P. DU PONCEAU, A DISSERTATION ON THE NATURE AND EXTENT OF THE JURISDICTION OF THE COURTS OF THE UNITED STATES 3 (Philadelphia 1824) ("The law of nations ... . defines offences and affixes punishments, and acts everywhere proprio vigore .... . Whether there is or not a national common law in other respects this universal common law can never cease to be the rule of executive and judicial proceedings until mankind shall return to the savage state.") (emphasis in original); W. RAWLE, A VIEW OF THE CONSTITUTION OF THE UNITED STATES OF AMERICA 104-05 (Philadelphia 1825) ("power to define and punish offences against the law of nations" is "with great propriety given to congress," "but if rnses arise for which no such statutory provision has 
murder at sea did not chance to depend only on this source of law. In 1790, in its first statute defining federal crimes, Congress legislated that piracy included any robbery on the high seas, or on rivers or bays outside the jurisdiction of a particular state, and was punishable by death. ${ }^{34}$ Stepping beyond the law of nations, Congress also extended the definition of piracy to include murder on the high seas, running away with a ship or vessel or with goods or merchandise of the value of fifty dollars, or any other offense punishable by death on land. Revolution against maritime governance was also transformed into statutory piracy: "any seaman [who] shall lay violent hands upon his commander, thereby to hinder and prevent his fighting in defence of his ship or goods committed to his trust, or [who] shall make a revolt in the ship" was deemed a pirate and felon. ${ }^{35}$ An "endeavor to make a revolt in [a] ship"36 was a lesser statutory offense, carrying up to three years imprisonment and a one thousand dollar fine, in the same class as manslaughter on the high seas and attempts to corrupt a mariner to commit piracy.

Shortly after the passage of the 1790 act, Supreme Court Justice James Wilson expressed his doubt that the full reach of this statute could be addressed to the conduct of non-Americans without injuring the jurisdictional precepts of the law of nations. Wilson's extraordinary charge to a Virginia grand jury ${ }^{37}$ suggests an early notion of judicial review that measured legislative legitimacy against the Constitution and the law of nations alike, declining to enforce a Congressional statute in excess of national prescriptive jurisdiction as allocated by international law. Wilson doubted the competence of the United States to vary from the substance of the law of nations when treating the conduct of noncitizens. Piracy under the law of nations was limited to "robbery and depredation on the high seas," and did not include homicide. ${ }^{38}$ Murder on the

been made, [state and federal] courts are thrown upon those general principles, which being enforced by other nations, those nations have a right to require us to apply and enforce in their favour, or for the benefit of their citizens and subjects."); F. WHARTON, supra note 6, at 87 n.* (1849) ("as congress has power to 'define and punish certain offenses against the law of nations,' the jurisdiction of the states is thereby divested of the particular subject matter; and that consequently as the jurisdiction exists somewhere, it exists in the federal courts ready to be executed ... when no legislation has taken place, through the agency of the common law."). Contra 4 ST. GEORGE TUCKER'S BLACKSTONE app. 10 (1803). The literature on federal common law crimes has proliferated. See Jay, Origins of Federal Common Law, 133 U. PA. L. REV. 1003, 1231 (1985); Preyer, Palmer \& Presser, Symposium: Federal Common Law of Crime, 4 LAW \& HIST. REV. 223 (1986).

34. Act of Apr. $30,1790, \S 8,1$ Stat. 112, 113-14.

35. Id.

36. Id. $\S 12,1$ Stat. at 115.

37. J. Wilson, Charge to the Grand Jury of the Circuit Court for the District of Virginia, May 23, 1791, Richmond, Virginia, in 2 THE DOCUMENTARY HISTORY OF THE SUPREME COURT OF THE UNITED STATES, 1789-1800: THE JUSTICES ON CIRCUTT, 1790-1794, at 166, 178-80 (Maeva Marcus ed. 1989); also in 2 THE WORKS OF JAMES WISSON 803, 812-14 (Robert G. McCloskey ed. 1967). In a practice common at the time, when Grand Jury charges were also political events, the charge was reprinted as a pamphlet. Justice Wilson delivered the same address to Grand Juries for the District of Maryland (Nov. 7, 1791) and the District of New York (Sept. 5, 1792), reprinted in newspapers in Philadelphia. See Dunlap's American Daily Advertiser, Dec. 5, 1791; Feb. 5, 6, \& 9, 1793.

38. J. Wilson, Charge to the Grand Jury of the Circuit Court for the District of Virginia, May 23, 1791, 
high seas was forbidden by maritime rules of "the general Law of Nations," but unlike the 1790 American statute, international maritime law recognized degrees of guilt in murder, depending on participation. ${ }^{39}$ Those who gave a wound were principals, and the rest were accessories. One country's legislation could depart from the law of nations "in cases affecting only its own citizens," and treaties could vary "so far as the alteration shall affect only the contracting parties." ${ }^{.40}$ But legislation could not vary from the law of nations when governing noncitizens and nontreaty nationals who acted on a foreign ship outside territorial waters. ${ }^{41}$ Justice Wilson carried his doubts to the extent of intimating that the Grand Jury should not indict under the 1790 statute if a noncitizen were to be presented. The law of nations was "universal in its authority over the civilized part of the world; and is supported by the consideration of its general utility, as well as that of its obligatory force." Political democracy's will was to be resisted by judges if it deviated from the impartial code of nations. ${ }^{42}$

Richmond, Virginia, supra note 37, at 178 (emphasis omitted).

39. Id. at 179 (emphasis omitted).

40. Id. (emphasis in original).

41. Municipal prescriptive jurisdiction was thus limited even where adjudicative and enforcement jurisdiction could be exercised to enforce the law of nations.

42. Id. (emphasis in original). Under the 1790 Crimes Act, the statutory language punishing murder on the high seas included any "person," Act of Apr. 30, 1790, $\$ \$ 8,12,1$ Stat. 112, 113-14, 115, rather than any "citizen," id. $\S 9,1$ Stat. at 114. Famous to our generation for his celebration of popular sovereignty, Wilson is uneasy in thwarting the legislature elected by the people:

Placed in the high and responsable office of a Judge of the United States, I feel myself under an official obligation to state some doubts, which arise in my mind, upon this part of the law. Impressed, as I ought to be, both as a citizen and a Judge, with the strongest regard for the legislative authority of the United States, I propose those doubts most respectfully, and with the greatest degree of diffidence.

J. Wilson, Charge to the Grand Jury of the Circuit Court for the District of Virginia, May 23. 1791, Richmond, Virginia, supra note 37 , at 178 . Yet his advice to the grand jury is clear enough, suggesting that even deliberate Congressional purpose to violate the law of nations might be resisted by a court:

On the supposition, that the [statutory] law was designed to extend, in its operation, to persons not citizens of the United States; can this design be carried into effect, consistently with the predominant authority of the law of nations, and of the universal law of society?

The case may very probably happen, and come before a Grand Jury for their official investigation. It was proper to suggest my doubts concerning it.

Id. at 180 (emphasis in original). In a Shelley $v$. Kraemer hue, a court may have its own immediate relationship to the law of nations, and be unwilling to carry out an international delict. See also P. DU PONCEAU, supra note 33, at $3 \mathrm{n}$. "The law of nations, being the common law of the civilised world, may be said, indeed, to be a part of the law of every civilised nation; but it stands on other and higher grounds than municipal customs, statutes, edicts, or ordinances. It is binding on every people and on every government. ... Every branch of the national administration, each within its district and its particular jurisdiction is bound to administer it."). Wilson stands in high contrast to the twentieth century view that domestic courts cannot use international law to test the legitimacy of federal legislation; compare L. HENKIN, FOREIGN AFFAIRS AND THE CONSTITUTION 221-22 (1972) ("courts will give effect to acts within the constitutional powers of the political branches without regard to international law").

In his Law Lectures at the University of Pennsylvania in 1790-1791, Wilson celebrated judicial execution of the law of nations as the seed of a new concord.

Hitherto that great law has been applied and administered by the force or by the pleasure of the parties in controversy: in the United States, it can now be applied and administered by impartiai, independent, and efficient, though peaceful authority. . . . [t]he exalted power of administering judicially the law of nations. . . . To every citizen of the United States, this law is not only a rule of conduct, but may be a rule of decision. As judges and as jurors, the administration of this law 
By early 1798, American authorities who found a British mutineer from a British ship within American territory had six possible choices, with (5) and (6) as the entrées that gave fullest deference to the powers of the House and Senate. The choices were:

(1) do nothing;

(2) expel the mutineer, as an alien, under an inherent right of sovereignty; 43

(3) indict and try the mutineer under the law of nations for murder or piracy, in an American court;

(4) extradite him to Great Britain by authority of the law of nations; ${ }^{44}$

(5) indict and try the mutineer under the 1790 federal statute for murder or piracy (subject to the difficulties suggested by Wilson); or

(6) extradite him to Great Britain under Article 27 of the Jay Treaty of 1794, which provided for "deliver[y] up to justice" of persons charged with "murder." 45

If the mutineer was American, the choices were much the same, though trial under American law posed less challenge to the limits of national prescriptive jurisdiction, and summary expulsion was excluded.

Even by 1798, the American Executive likely understood there was no wisdom in disdaining acts of the Congress or Senate that provided for the problem at hand. Hence, though (4) will also figure, (5) and (6) were to be regarded as the most serious courses of action in the Hermione aftergame.

is, in many important instances, committed to their care. What a beautiful and magnificent prospect of government is now opened before you! The sluices of discord, devastation, and war are shut: those of harmony, improvement, and happiness are opened!

J. WILSON, Of Man, as a Member of the Great Commonwealth of Nations, in 1 THE WORKS OF JAMES WILSON, supra note 37 , at 282 (paragraphing omitted).

43. Later in 1798, the controversial Alien Act would authorize the President to expel any alien judged by the President to be "dangerous to the peace and safety of the United States." An Act concerning Aliens, $\S 1,1$ Stat. 570,571 (June 25, 1798).

44. Grotius, Rutherforth, and Vattel held there was a mandatory duty under the law of nations to punish or extradite aliens and subjects guilty of heinous offences abroad, lest a cause for war be presented. Zouche, Pufendorf, and Von Martens held to a more positivist view, that the obligation arose only by the express agreement of contracting states.

For variations in these broad characterizations, see $H$. GROTIUS, DE JURE BELLI AC PACIS LIBRI TRES [THE RIGHTS OF WAR \& PEACE], bk. 2, ch. 21, I 4 (Paris 1625; W. Evats trans. London 1682); T. RUTHERFORTH, INSTITUTES OF NATURAL LAW, supra note 28 , bk. 2, ch. 9, § 12; E. VATTEL, LE DROIT DES GENS, OU PRINCIPES DE LA LOI NATURELLE, APPLIQUE A LA CONDUTTE ET AUX AFFAIRES DES NATIONS ET DES SOUVERAINS [THE LAW OF NATIONS], bk. 2, ch. 6, \$ 76 (London 1758; trans. London 1760); R. ZOUCHE, JURIS ET JUDICII FECIALIS, SIVE, JURIS INTER GENTES, ET QUAESTIONUM DE EODEM EXPLICATIO [AN EXPOSITION OF FECIAL LAW AND PROCEDURE, OR OF LAW BETWEEN NATIONS, AND QUESTIONS CONCERNING THE SAME], pt. 21 § 5, q. 2, 3, at 106-07 (Oxford 1650; J. Brierly trans. 1911); S. PUFENDORF, ELEMENTORUM JURISPRUDENTIAE UNIVERSALIS LIBRI DUO [THE ELEMENTS OF UNIVERSAL JURISPRUDENCE], bk. I, def. 12, at 206 (Cambridge 1672; W. Oldfather trans. 1931); G.F. VON MARTENS, PRÉCIS DU DROIT DES GENS MODERNES DE L'EUROPE [THE LAW OF NATIONS, FOUNDED ON THE TREATIES AND CUSTOMS OF THE MODERN NATIONS OF EUROPE], bk. 3, ch. 3, § 22, at 108-09 (Göttingen 1788; W. Cobbett trans. Philadelphia 1795).

45. Treaty of Amity, Commerce and Navigation, signed at London, Nov. 19, 1794, United States-Great Britain, art. 27, 8 Stat. 116, 129, T.S. No. 105. 
Because it was central in the political debate, the language of entree (6), the Jay Treaty article, bears attention and is reproduced in the margin. ${ }^{46}$ Construction of the treaty article would require several interpretive choices. What was "murder" under the treaty? Should murder be judged by the national law of each treaty partner, by a definition peculiar to the treaty regime, or alternatively, by the law of nations, a universalized standard for homicidal acts? In each, the clash between a revolutionary and nonrevolutionary law was only too evident. Was it "murder" to kill tyrants? Who would judge of tyranny? ${ }^{47}$ We will not see any simple answer to these, especially in the setting of maritime governance. Republicans too believed in facilitating commerce and carriage, as the lifeblood for an agricultural republic; few sought commercial isolation; shipboard discipline was a problem for all maritime powers. Yet the treaty interpretations that might be offered by the President, Senate, or courts were prey to the challenge that a democratic assembly would have answered the questions differently. As organ of popular voice, the House of Representatives might feel a particular jealousy in pronouncing on the right of revolution, in distinguishing tyrannicide and crime. A treaty-wielding President and Senate could trammel the Constitution's delegation to the Congress of special powers over crime and punishment: the guarantee of House power to set venue for the trial of crimes "not committed within any State." 48 The House might register all the more pique in a maritime setting in light of its constitutional power "to define and punish Piracies and Felonies committed on the high Seas, and Offences against the Law of Nations."49

One other complication was created by the Jay Treaty. Though piracy was not included among extraditable offenses, in Article 20 the United States had pledged itself to give no reception or assistance to "any pirates," and to "bring to condign punishment" any "inhabitants" assisting piracy. ${ }^{50}$ One could take

46. In Article 27 of the Jay Treaty, the treaty parties of the United States and Great Britain had agreed that his Majesty and the United States, on mutual requisitions, by them respectively, or by their respective ministers or officers authorized to make the same, will deliver up to justice all persons, who, being charged with murder or forgery, committed within the jurisdiction of either, shall seek an asylum within any of the countries of the other, provided that this shall only be done on such evidence of criminality, as, according to the laws of the place, where the fugitive or person so charged shall be found, would justify his apprehension and commitment for trial, if the offence had there been committed. The expence of such apprehension and delivery shall be borne and defrayed, by those who make the requisition and receive the fugitive.

\section{Stat. at 129.}

47. The questions were not clarified by the treaty proviso, that said extradition could proceed only upon "such evidence of criminality, as, according to the laws of the place, where the fugitive or person so charged shall be found, would justify his apprehension and commitment for trial, if the offence had there been committed." Was this a choice of laws provision to govern the underlying conduct, or only a standard for quantum of evidence?

48. U.S. CONST. art. III, $\S 2, \mathrm{cl} .3$ "The Trial of all Crimes, except in Cases of Impeachment, shall be by Jury; and such Trial shall be held in the State where the said Crimes shall have been committed; but when not committed within any State, the Trial shall be at such Place or Places as the Congress may by Law have directed.").

49. U.S. CONST. art. I, \& \&, cl. 10.

50. Article 20 of the Jay Treaty read in pertinent part: 
this treaty article as reaching only classical pirates, or, at the other extreme, as consenting to full application of the 1790 American law of piracy to British nationals. Either way, who was a pirate in lingua pacta posed conundrums for a country fresh from revolution. ${ }^{51}$

How to act upon the treaty was the other puzzle. The British Constitution had no rule automatically incorporating treaties into domestic law, and so Parliament acted to implement the extradition article of the Jay Treaty. ${ }^{52}$ Parliament authorized His Majesty's principal secretaries of state to warrant receipt of an American request for a fugitive, and to require any Justice of the Peace to give aid in apprehending and committing the offender. The JP's were to "examine upon oath any Persons or Person touching the Truth of such Charge," and to commit the fugitive for surrender to American pursuers "upon such Evidence as, according to the Laws of this Kingdom, would justify the Apprehension and Commitment for Trial." 53

No implementing legislation was passed in the United States, under constitu-

It is further agreed that both the said contracting parties, shall not only refuse to receive any pirates into any of their ports, havens, or towns, or permit any of their inhabitants to receive, protect, harbor, conceal or assist them in any manner, but will bring to condign punishment all such inhabitants as shall be guilty of such acts or offences.

And all their ships with the goods or merchandizes taken by them and brought into the port of either of the said parties, shall be seized as far as they can be discovered, and shall be restored to the owners, or their factors or agents, duly deputed and authorized in writing by them (proper evidence being first given in the court of admiraity for proving the property) even in case such effects should have passed into other hands by sale, if it be proved that the buyers knew or had good reason to believe, or suspect that they had been piratically taken.

8 Stat. at $126-27$.

51. The classical definition of piracy might fit some of the Hermione mutineers. For beyond displacing the captain's command and ending his life, they had looted the ship of silver plate and silverware, and accepted money from the Spanish governor for the ship's surrender.

52. An Act for Carrying into Execution the Treaty of Amity, Commerce, and Navigation, Concluded Between His Majesty and the United States of America, 37 Geo. 3, ch. 97, \& 26 (1797). Confirming legislation was especially prudent because in the famous Habeas Corpus Act a century earlier, Parliament had acted to restrict the King's power to send any "subject" as "[p]risoner . . . into Parts, Garrisons, Islands, or Places beyond the Seas, which are ... within or without the Dominions of his Majesty." See An Act for the Better Securing the Liberty of the Subject, and for Prevention of Imprisonments Beyond the Seas (Habeas Corpus Act), 31 Car. 2, ch. 2, § 12 (1679).

53. An Act for Carrying into Execution the Treaty of Amity, Commerce, and Navigation, Concluded Between His Majesty and the United States of America, 37 Geo. 3, ch. 97, § 26 (1797). The Act provided: in case Requisition shall at any Time be made . . . it shall be lawful for one of his Majesty's Principal Secretaries of State, by Warrant under his Hand and Seal, to signify that such Requisition has been so made, and to require all Justices of the Peace, and other Magistrates and Officers of Justice, to govern themselves accordingly, and to be aiding and assisting in apprehending the Person so charged, and committing such Person, for the Purpose of being delivered up to Justice, according to the Provisions in the said Article, and thereupon it shall be lawful for any Justice of the Peace, or other Person having Power to commit for Trial Persons charged with Offences against the Laws of this Kingdom, to examine upon Oath any Persons or Person touching the Truth of such Charge, and upon such Evidence as, according to the Laws of this Kingdom, would justify the Apprehension and Commitment for Trial of the Person so charged, if the Offence wherewith he shall be so charged had been committed in this Kingdom, it shall be lawful for such Justice of the Peace, or other Person having Power to commit as aforesaid, to commit the Person so charged to his Majesty's Gaol .... 
tional circumstances we will soon examine. No federal court had clear authority to aid in the treaty article's execution. Only the Indian tribes had treaties with the United States concerning fugitive offenders when the 1789 Judiciary Act was passed, and these did not promise delivery of offenders to Indian jurisdiction. ${ }^{54}$ It remained an open question whether the jurisdictional reach of the 1789 Judiciary Act could be stretched to cover extradition matters. ${ }^{55}$

\section{ForEIGN AFFAIRS AND POPULAR VOICE: THE HOUSE OF REPRESENTATIVES AND THE TREATY POWER}

Substance and form, result and procedure, were linked from the first in the Robbins affair. In Republican eyes, the moral error in returning a sailor to British discipline against a claim of impressment - a result deemed unfaithful to revolutionary origin-was committed because of the use of undemocratic forms of decision. A right of rebellion that should have been decided in the last resort by jury or grand jury, would instead be spurned by a judge sitting in uncertain jurisdiction. And an extradition arrangement that, in Republican view, supplied unwarranted aid to the British, was acted on at all because of the Federalist pretension that treaty provisions were self-executing-that a pact blessed by President and Senate could be applied in domestic affairs without approval and legislative implementation from the House of Representatives.

A gnostic reading of early constitutional law reveals the hidden key of treaty power. Nowadays we center our constitutional law courses on issues of unenumerated heads of legislation, the scope of interstate commerce, and the consolidation of judicial review of constitutionality. But these are not central to the first two decades of the instruments of union. Rather, the crisis of the Articles of Confederation pivoted on our inability to enforce the treaty terms of the 1783 peace, in particular, the treaty promise that British debts would not be obstructed. ${ }^{56}$ The matter threatened the stark independence of the country.

54. The early Indian treaties are collected in 7 Stat. (1861). Indians accused of capital crimes against United States citizens were to be surrendered to United States jurisdiction. Citizens of the United States were to be tried within ordinary United States domestic jurisdiction for crimes against Indians.

55. By section 33 of the 1789 Judiciary Act, any federal judge, or state justice of the peace or magistrate, could arrest and imprison or bail offenders, but only "for trial before [a] court of the United States" and for a "crime or offence against the United States." See An Act to establish the Judicial Courts of the United States, $\S 33,1$ Stat. 73, 91 (Sept. 24, 1789) (emphasis added). By section 9 of the 1789 Act, district courts had "cognizance" of any crimes "cognizable under the authority of the United States" carrying punishments up to six months imprisonment, one hundred dollars, or thirty stripes, including crimes on the high seas, id. $\$ 9,1$ Stat. at 76-77; by the severity of punishment, murder was beyond the district court's ken. Section 11 of the 1789 Judiciary Act allowed federal circuit courts to take "cognizance" of all crimes "cognizable under the authority of the United States," id. \$ 11, 1 Stat. at 78-79; the reach of "cognizable under the authority" might be taken as limited to crimes punishable by the United States, or crimes actually being prosecuted by the United States. These assignments tacity combined the criminal jurisdictions of common law, admiralty and maritime. Federal district courts also had exclusive original jurisdiction of civil causes of admiralty and maritime law, see id. $\$ 9,1$ Stat. at 77 . The 1789 Judiciary Act placed no "federal question" jurisdiction in federal trial courts for cases arising under treaties.

56. Article 4 of the 1783 Treaty provided that "creditors on either side, shall meet with no lawful 
Ominous occupation of the forts on the Northwest border and denial of navigation on the St. Lawrence and Great Lakes were used by the British as bargaining levers to retaliate for the American states' reluctance to restore sequestered property or to permit commercial suits in state court by British and Loyalist creditors for recovery of debts.

In his Vices of the Political System of the United States, ${ }^{57}$ prepared just before the Annapolis Convention, Madison complained prominently of the continuing violation of American treaty obligations by the popular governments of the states. Inexorable temptations were created by popular election. State legislation was driven by citizens' aggregate status as debtors or creditors. Paper money, installment payment of debts, and "occlusion of Courts" constituted dangerous "aggressions on the rights of other states." These were frauds "which might . . . involve the Union in foreign contests." The structure of state government could not be fitted to treaty observance. "From the number of Legislatures, the sphere of life from which most of their members are taken, and the circumstances under which their legislative business is carried on, irregularities of this kind must frequently happen." A part of the Union should not be able to bring "the greatest of public calamities" upon the whole. ${ }^{58}$

The new Constitution's Article VI supremacy clause, Article III extension of federal judicial power to cases arising under treaties, and creation of foreign diversity jurisdiction, looked to the fulfillment of American treaty and international obligations, serving the peremptory rule of the law of nations that promises must be kept, pacta sunt servanda. But even after Madison's concerns were addressed by the innocent text, fitting the working parts remained a contest. The Supreme Court's first crisis of legitimacy under the Constitution hazarded foreign commercial and treaty obligations. The Court's cosmopolitan reading of Article III in Chisholm v. Georgia, ${ }^{59}$ dashing state sovereign immunity and permitting federal court suits against state governments by out-of-state claimants, was seen by many as an invitation to British and Loyalist creditors to recover from the states debts confiscated in the Revolution. ${ }^{60}$ The Supreme

impediment to the recovery of the full value in sterling money, of all bona fide debts heretofore contracted." Definitive Treaty of Peace, signed Sept. 3, 1783, United States-Great Britain, art. 4, 8 Stat. 80, 82, T.S. No. 104. Congress also pledged to "earnestly recommend" state restitution of confiscated British and Loyalist estates. Id., art. 5, 8 Stat. at 82-83. Identical promises were made in the Preliminary Articles of Peace, signed Nov. 30, 1782, United States-Great Britain, arts. 4 \& 5, 8 Stat. 54, 56, T.S. No. 102 (also called the "Provisional Articles Between the United States of America and his Britannic Majesty").

57. J. Madison, Vices of the Political System of the United States (April 1787), in 9 THE PAPERS OF JAMES MADISON 345 (R. Rutland ed. 1975).

58. Id. at $349-50$.

59. 2 U.S. (2 Dall.) 419 (Feb. 18, 1793).

60. For example, in Ware v. Hylton, 3 U.S. ( 3 Dall.) 199, 214 (1796), attorney John Marshall argued that where a Virginia debtor had paid the amount of the debt into the Virginia state treasury and now was asked to pay the debt again, "upon every principle of equity and law, it ought to be presumed, that the recovery, which [the framers of 1783 treaty article 4] contemplated, was intended against the receiving state, not against the paying debtor." See also Vassal v. Massachusetts (unreported case in 1793 Term brought by British Loyalist to recover confiscated properties), discussed in 1 J. GOEBEL, JR., HISTORY OF THE 
Court was placed under siege by the Eleventh Amendment, which reversed Chisholm's result. ${ }^{61}$ This rebuff by the Congress and the States, restoring state fiscal immunity by limiting the federal judicial power, ${ }^{62}$ was a warning shot announcing that Article III was not inviolable, and that treaty power was not a welcome intrusion into areas of popular concern such as land ownership and the relations of debtors and creditors. The Eleventh Amendment would be followed in turn by the Republican repeal of the short-lived 1801 federal question jurisdiction in the 1802 Judiciary Act, ${ }^{63}$ limiting the ability to resort to federal court in the first instance for cases arising under treaties.

The Court may be seen responding to these events in a manner designed to preserve the effective supremacy of American treaty understandings against state interference. Ware $v$. Hylton ${ }^{64}$ works a harsh result, retrospectively reviving a debt owed by a Virginian to a British creditor even though the debtor already had paid the amount to the state government pursuant to a wartime sequestration statute. The Justices are crafting a remedy against an available defendant in the face of the threatened procedural immunity of the states. Justice Story's insistence in Martin v. Hunter's Lessee ${ }^{65}$ that the Jay Treaty

SUPREME COURT OF THE UNTED STATES: ANTECEDENTS AND BEGINNINGS TO 1801, at 734-37 (1971); Independent Chronicle (Boston, Mass.), July 18, 1793, at 2, col. 3 ("prospects of numerous fictitious actions being soon commenced by refugees against every State in the Union, are circumstances truly alarming ... . [they will] drain the Treasury of every State by constant demands from TORIES") (emphasis in original); id., Sept. 13, 1793, at 3, col. 2 ("If it is admitted that the State may be sued in all cases, ... nothing remains but to give the key of our treasury to the agents of the Refugees, Tories and men who were inimical to our Revolution, to distribute the hard money now deposited in that office to persons of this description.") (emphasis in original). See $1 \mathrm{~J}$. GOEBEL, JR., supra, at 741-42; C. JACOBS, THE ELEVENTH AMENDMENT AND SOVEREIGN IMMUNTY 70-71 (1972).

61. Congress approved the Eleventh Amendment in 1794; President Adams deemed the necessary ratifications to have been received by January 8,1798 . In fact the needed state ratifications were accomplished by early 1795 , but notification was not promptly received from several of the states. See UNTED STATES CONSTITUTION SESQUICENTENNIAL COMM., HISTORY OF THE FORMATION OF THE UNON UNDER THE CONSTITUTION 63 (S. Bloom ed. 1935); Mathis, The Eleventh Amendment: Adoption and Interpretation, 2 GA. L. REV. 207, 227-28 \& n.77 (1968); C. JACOBS, supra note 60, at 67, 180 nn. 95 \& 96; Joint Resolution of Mar. 2, 1797, 1 Stat. 519 (President is "requested to adopt some speedy and effectual means of obtaining information from the states of Connecticut, New Jersey, Pennsylvania, Maryland, Virginia, Kentucky, Tennessee, and South Carolina, whether they have ratified the amendment proposed by Congress to the Constitution concerning the suability of states; if they have, to obtain the proper evidences thereof."); Message of John Adams to the Congress (Jan. 8, 1798), 1 MESSAGES AND PAPERS OF THE PRESDENTS 260 (J. Richardson ed. 1896). See also 1 THE DEBATES IN THE SEVERAL STATE CONVENTIONS ON THE ADOPTION OF THE FEDERAL CONSTITUTION . . . TOGETHER WITH . . . OTHER ILLUSTRATIONS OF THE CONSTITUTION [ELLIOT's DEBATES] at 340-41 (J. Elliot 2d ed. Philadelphia 1836) (initial returns from state legislatures on Eleventh Amendment reflected in House Journal).

62. It has been suggested recently that the Eleventh Amendment meant to preclude only party-based jurisdiction (suits brought in federal court under diversity or foreign diversity jurisdiction), still preserving the possibility of trial court federal question jurisdiction. See Gibbons, The Eleventh Amendment and State Sovereign Immunity: A Reinterpretation, 83 COLUM. L. REV. 1889 (1983); Fletcher, A Historical Interpretation of the Eleventh Amendment, 35 STAN. L. REV. 1033 (1983). Without legislative assignment of federal question jurisdiction or Article III self-execution, the issue was not immediately at hand for review. But it is clear that the exercise of any federal jurisdiction to enforce commercial and treaty obligations against state defendants would have evoked great hostility in some quarters.

63. Act of Mar. 8, 1802, § 1, 2 Stat. 132 (repealing Act of Feb. 13, 1801, 2 Stat. 89).

64. 3 U.S. (3 Dall.) 199 (1796).

65. 14 U.S. (1 Wheat.) 304 (1816). Martin enforces the holding of Fairfax's Devisee v. Hunter's Lessee, 
could confirm the land title of a British alien, even though the claimant had earlier been made ineligible by state statute, may be taken as another lesson to the states to yield to the wedge of the treaty power. ${ }^{66}$ The hints of selfexecuting federal court jurisdiction in Marbury v. Madison ${ }^{67}$ and Martin $v$. Hunter's Lessee may be read as Federalist warning that popular intrusion into Article III might not be forever suffered-that the Founding's investiture of jurisdiction in the judicial branch might be found immune from Congressional restriction or inaction. ${ }^{68}$ The crucial role of federal courts in fulfilling international obligations underlies much of this.

The use of treaty power in Jonathan Robbins concerned personal liberty, ever more acute for Republican sentries than the property at stake in creditors' claims. Before we enter the course of the Robbins debate, we should remind ourselves of the range of Republican scruples concerning treaty power and its competition with Congress' legislative power.

Some have suggested that with the Constitution's supremacy clause ${ }^{69}$ the question whether treaties should have bite as enforceable domestic law was

11 U.S. (7 Cranch) 603 (1813).

66. One might even read Calder v. Bull, 3 U.S. (3 Dall.) 386 (1798), in this light. Limiting the ban on ex post facto laws to criminal statutes would quash any argument that United States treaties could not be applied, retrospectively, to revive the enforceability of British debts already discharged under state law.

67. 5 U.S. (1 Cranch) 137 (1803).

68. The possibility of a self-executing Article $\mathrm{m}$ may be discerned in Marbury's argument that a remedy for violation of a federally created right must be found somewhere within federal judicial power. See also Martin v. Hunter's Lessee, 14 U.S. (1 Wheat.) at 328-33; 3 J. STORY, COMMENTARIES ON THE ConstTruTION 449 (1833); Eisentrager v. Forrestal, 174 F.2d 961, $965-66$ (D.C. Cir. 1949) (jurisdiction to issue the writ of habeas corpus), rev'd on other grounds sub nom. Sohnson v. Eisentrager, 339 U.S. 763 (1950); cf. United States v. Torres, 751 F.2d 875 (7th Cir. 1984), cert. denied, 470 U.S. 1087 (1985) (court has inherent power to issue Fourth Amendment warrant for search technique unanticipated by FED. R. CRIM. P. 4l(a)).

Article III instructs that the judicial power is vested in the Supreme Court and such inferior courts as Congress may create. If one accepts the natural law reading of vestedness offered by Justice Johnson in Fletcher v. Peck, 10 U.S. (6 Cranch) 87, 143 (1810), one might even argue that vested judicial power is immune from constitutional amendment. Recall that the Constitution was supposed to create a perpetual union. Seeking to persuade the people to redistribute powers from state to central government and to suffer changes of position that practicably may be irreversible, it is not beyond reason to place the fundamental safeguards of the new government outside the reach of change by amendment-for amendment requires only a few votes beyond three-eighths of state legislators or convention delegates (a simple majority of legislators/delegates in three-quarters of the states) once Congress has approved.

The Article $V$ proviso excepting two specific matters from constitutional amendment does not forbid such a reading; a proviso would have seemed superfluous for acts of amendment deemed beyond the pale of reasonable men. Rights inalienable in 1776 would not likely be thought subject to positivist "amendment" in 1787; the fundamental safeguards of rights might be similarly placed beyond any legal invasion. For a view arguably looking in the same direction, see Speech of Senator Plumer (Dec. 1, 1803), in WILLIAM PLUMER'S MEMORANDUM OF PROCEEDINGS IN THE UNTTED STATES SENATE, 1803-1807, at 54 (E. Brown ed. 1923) (Constitution's "forms \& modes of proceeding ... may be amended" but "its principles cannot be changed or its substance impaired without the consent \& express approbation of each state." Article $V$ procedure could not be used to "materially ... change" Article IV's guarantee of republican government or to alter requirement that a state's consent be obtained for any cession of its territory to form a new state) (emphasis omitted).

69. U.S. CoNST. art. VI ("This Constitution, and the Laws of the United States which shall be made in Pursuance thereof; and all Treaties made, or which shall be made, under the Authority of the United States, shall be the supreme Law of the Land ...."). 
answered with authority once and for all. ${ }^{70}$ But if one approaches the Convention and ratification in a less argumentative stance, one hears voices of deep concern, wondering how the treaty power and legislative powers could be reconciled. Nascent republicans argued tenably that treaties should not operate directly in any case placed by Article I within the legislative competence of the Congress. Treaties are made the supreme law of the land in the same Constitutional breath with the supremacy of statutes and of the Constitution, and no text gives treaties top billing. One could imagine a doctrine, similar to commerce clause pre-emption of burdensome state legislation, that treaty provisions trenching on subjects at the core of federal legislative competence are preempted in their effect on domestic law-that such treaties will not be deemed self-executing but rather depend for their implementation and observance on House concurrence. Though this would pose difficulties for the good faith of the United States in international engagements, it could simply mean the President and Senate should refrain from making unconditional promises without first assuring themselves of House consent. The short elective term of the House makes assurance hard to come by, but a constitutional stoic could reply easily, that is the price of democracy. If confirming legislation is required, then delay the deposit of ratification until the legislation is passed. Of course the stoic would have to differ with Chief Justice John Jay, who believed the law of nations creates a positive duty to ratify a pact following signature if instructions and powers have been observed. ${ }^{71}$

The Founders' views of the roles of the President, Senate, and House in treaty implementation depended first upon the basic structure of government. The Constitution's frame of a bicameral legislature with independently elected President is too easily taken as destined. With our minds engaged by Montesquieu, we tend to forget that until quite late in the Constitutional Convention there was support for a semi-parliamentary form of government, in which the Executive would have been chosen by the Congress for a fixed term. This was true of the New Jersey Plan (Paterson Resolutions), the Virginia Plan (Randolph Resolutions), the Amended Virginia Plan (as adopted by the Committee of the Whole on June 19 and as committed by the Convention to the Committee on Detail on July 24), and the reconstructed version of the Pinckney Plan. ${ }^{72}$ Independent election of the President, though part of

70. E.g., Paust, Self-Executing Treaties, 82 AM. J. INT'L L. 760, 781 (1988) (implementing legislation required only where treaty language eschews direct judicial enforcement of the treaty or where Congress' power to declare war is at stake).

71. See Report of John Jay, as Secretary for the Department of Foreign Affairs (July 4, 1785), in 29 JOURNALS OF THE CONTINENTAL CONGRESS 500, 508, 509, 513 (J. Fitzpatrick ed. 1933).

72. To be sure, the plans varied in the relative independence of the Executive. The Amended Virginia Plan provided the most independence, with a seven-year term for an Executive and ineligibility for a second term. The New Jersey Plan made the members of its collective Executive ineligible for a second term but allowed them to be removed by Congress, on application by a majority of the Governors of the several states. The Pinckney Plan, if one credits the draft found among James Wilson's papers, required annual election of the Executive by the Congress, and permitted re-election. See 1 THE RECORDS OF THE FEDERAL 
Hamilton's plan, was twice defeated in the Constitutional Convention. ${ }^{73}$ Yet fears were expressed consistently that Congressional election of the Executive would give undue play to the cabals and intrigues of a popular body, that the judgment and vigor of the Executive would be eroded by dependence upon legislators' particular favor. Direct attachment to the legislature was seen as enfeebling and corrupting.

In the fourth month of the Constitutional Convention, on September 4, 1787, an independently selected President was agreed upon. ${ }^{74}$ Populous states gained the advantage of more Presidential electors, since electors were chosen in the same number as Representatives and Senators. Yet the factions of Congress might be thwarted through the decentralized choice of electors by each state legislature. Even then, the power remaining in the House to resolve tied Presidential elections caused great unease.

In light of the late move to an independent President, it should not surprise us that early debates conceived of treaty-making as a function for the Senate. The Committee on Detail's draft Constitution, reported on August 6, 1797, placed the power to make treaties entirely in the Senate. ${ }^{75}$ Only in the September 10 amended draft, submitted to the Committee on Style, was the power to make treaties finally divided between the independently elected President and the Senate. ${ }^{76}$

From the first there was the concerted view that treaty-making was unsuitable for the popular temper of the House. Though the Senate might have aristocratical tendencies, its longer term of office allowed a broad view of national interests and a patience for gradual results. Small numbers permitted

CONVENTION OF 1787, at 21, 23, 244 (M. Farrand ed. 1937); 3 id. at 593-616; 1 THE DocUMENTARY HISTORY OF THE RATIFICATION OF THE CONSTITUTION: CONSTITUTIONAL DOCUMENTS AND RECOROS, 17761787 , at 244, 246, 249, 252, 258-59 (State Historical Society of Wisconsin, M. Jensen ed. 1976). Building upon the work of J. Franklin Jameson, Farrand doubts the authenticity of Pinckney's own 1818 reconstruction of his $1787 \mathrm{draft}$ with an independently elected Executive, looking instead at the positions taken by Pinckney in debate, reflected in the draft found in Wilson's hand among the papers of the Committee of Detail. Farrand doubts as well whether the pamphlet published by Pinckney after the Convention fully reflected Pinckney's original plan. Merrill Jensen also credits the account of the Pinckney Plan recorded by James Wilson.

73. The proposals were made and defeated on June 2 and July 17, 1787. 1 THE RECORDS OF THE FEDERAL CONVENTION OF 1787, supra note 72 , at 77, 80-81, 230; 2 id. at 22,32 .

74. $2 \mathrm{id}$. at 497-500. The parallel to a parliamentary form could not work in American government, so long as one took seriously the role of the Senate in dampening legislative passions. Modern English Parliamentary government is based upon effective unicameral control of the executive; the victorious party in the English Commons forms a government, and Lords has little voice in the matter. In the eighteenth century, Lords maintained a weightier voice, but the responsibility for appointing a Government rested finally and decisively with the Crown. In the American system, with no Crown anchor and the American Senate as a second representative body, stalemate and swamping are two unattractive possibilities, were a President to be chosen by the federal legislature. If the Senate and House voted separately for President, they might fail to agree on a choice: potential stalemate. If the Senate and House voted in a single joint ballot, the senatorial voice of the small states would be swamped by the predominance of large states in the House.

75. 1 THE DOCUMENTARY HISTORY OF THE RATIFICATION OF THE CONSTITUTION: CONSTITUTIONAL DOCUMENTS AND RECORDS, 1776-1787, supra note 72, at 265.

76. Id. at $277,279$. 
dispatch and secrecy in advising on instructions and reviewing negotiations; the longer term also aided consistency between instructions and advice and consent. Influence for small states was essential, for sovereignty and territory were immediately at stake in treating with foreign powers on crucial matters of war and peace. The uncharted scope of treaty power was seen not as recommendation for numerical representation, rather as reason for assuring effective voice to each state, placing the competence in the Senate with two-thirds of a quorum to consent to ratification, investing veto power in a minority. The indirect election of the Senate and President was recommendation too, thought John Jay in Federalist No. 64; this mode "has . . . vastly the advantage of elections by the people in their collective capacity" where one need fear "the activity of party zeal, taking advantage of the supineness, the ignorance, and the hopes and fears of the unwary and interested."

The House's defects redoubled the Senate's virtues. In the House, secrecy was at risk. ${ }^{77}$ Popular passions and short-sighted fevers might hold sway. The rapid turn-over of members imperiled consistency: the instructions acted upon by negotiators might be repudiated by a new round of Representatives. Much as Madison had castigated popular government in the states, the House was assailed as peculiarly ill-suited for the exercise of treaty power because of its close control by a self-interested electorate. The popular interest represented by House members would have to be vindicated through the President's role as partner to the Senate in treaty-making.

But the uncertain range of treaty power, its status as domestic law, and even the prospect that treaties might take precedence over later-in-time federal legislation ${ }^{78}$ left many uneasy. James Wilson moved in the Philadelphia Convention that the House should be asked for its advice and consent in making treaties. "As treaties," he said, "are to have the operation of laws, they ought

77. See, e.g., DAVID RAMSAY, AN ADDRESS TO THE FREEMEN OF SOUTH CAROLINA, ON THE SUBJECT OF THE FEDERAL CONSTITUTION (Charleston 1788), in PAMPHLETS ON THE CONSTITUTION OF THE UNTTED STATES, PUBLISHED DURING ITS DISCUSSION BY THE PEOPLE, 1787-1788, at 376 (P. Ford ed. 1888 \& reprint 1971) ("who can be more properly trusted with the power of making [treaties] . . . Can the Continental House of Representatives? When sixty-five men can keep a secret, they may.").

78. Twentieth-century ears may prickle at the Federalist claim that a ratified treaty can limit Congress' freedom to legislate in areas of concurrent competence. But this was, clearly, the view of Jay, Hamilton, and others. See J. JAY, THE FEDERALIST No. 64 (1787) ("The proposed Constitution ... has not in the least extended the obligation of treaties. They are just as binding, and just as far beyond the lawful reach of legislative acts now, as they will be at any future period, or under any form of government."); Speech of William Davie in the North Carolina Convention (July 28, 1788), in 3 THE RECORDS OF THE FEDERAL CONVENTION OF 1787, supra note 72, at 347 ("All civilized nations have concurred in considering [treaties] as paramount to an ordinary act of legislation"); A. HAMITON, The Defence No. 38 (1795), in 20 THE PAPERS OF AlEXANDER HAMILTON 22, 25 n.* (H. Syrett ed. 1974) (treaty power was "understood by all" at Philadelphia to be "competent ... to controul \& bind the legislative power of Congress"; "no objection was made to the idea of its controuling future exercises of the legislative power.") (emphasis omitted); $c f$. 1 W. BLACKSTONE, COMMENTARIES ON THE LAWS OF ENGLAND 249 (2d ed. Oxford 1766, 1st Am. ed. Philadelphia 1771) ("Whatever [foreign] contracts therefore [the king] engages in, no other power in the kingdom can legally delay, resist, or annul."). 
to have the sanction of laws also."79 The benefits of secrecy and dispatch did not outweigh the need for democratic voice. Wilson's proposal lost ten to one in the Convention, with only his state of Pennsylvania in favor, ${ }^{80}$ but other voices were heard. Some delegates to the Convention wished to make it easier to ratify peace treaties, lest a self-interested Executive or Senatorial minority profit by prolonged war. ${ }^{81}$ Madison wondered whether "a distinction might not be made between different sorts of Treaties," requiring House concurrence in treaties other than those of alliance. ${ }^{82}$

In the state ratifying conventions extraordinary fears were aired that the treaty power could become a form of aristocratic prerogative; the Senate, after all, was at remove from the people; state legislators could select Senators by any means they might prefer. The House had many competencies in foreign affairs among its powers of legislation, and it seemed likely that treaties would press on some of these. ${ }^{83}$ Though promise-making is different from unilateral action, one could not consistently argue that the House should be excluded from foreign affairs for want of expertise without radically altering Article I, section 8. The Crown's prerogative power in foreign affairs, exercised through the Privy Council, lent an unsettling parallel to the Senate and President's control of treaty power. Said the "Sentiments of Many":

We have hitherto been taught that all laws binding on the community, ought to be made with the consent of the people, or by that of their representatives, in their legislative capacity. But under the new constitution, Congress is to enact some laws, others to be enacted by a part of Congress, or one branch of the legislature, and these to be made supreme... . Would a sensible and free people, covet to have the supreme laws of their land, impressed with such "lovely features"[?] ${ }^{84}$

79. Debate of Sept. 7, 1787, 2 THE RECORDS OF THE FEDERAL CONVENTION OF 1787, supra note 72, at 538 .

80. Id. An earlier proposal by Gouverneur Morris of New York, that "no Treaty shall be binding on the U.S. which is not ratified by a law," was also defeated, with only Pennsylvania in favor and North Carolina divided. See Debate of Aug. 23, 1787, 2 id. at 392-94.

81. Madison's proposal to permit the Senate to ratify peace treaties without the President's assent, was defeated. He also moved to allow a simple majority of the Senate, concurring with the President, to approve a treaty of peace. Other delegates countered that in peace treaties the "dearest interests" were likely to be compromised, such as fisheries and territory, with unusual hazard to border states, requiring peace treaties to remain under minority check. Debate of Sept. 7, 1787, 2 id. at 540-41.

82. Debate of Aug. 23, 1787, 2 id. at 394. Madison would have excluded the House from "Treaties eventual and of Alliance for limited terms." Id. Madison also recorded a suggestion that the concurrence of the House should be required where "the territorial boundaries of the U.S. may be contracted" or fishing rights abridged. Debate of Sept. 7, 1787, $4 \mathrm{id}$. at 58 . This suggestion was not formally moved or voted upon. Id.

83. See GEORGE MASON, Objections to this Constitution of Government (1787), in 3 THE PAPERS OF GEORGE MASON 991, 992 (R. Rutland ed. 1970) ("By declaring all treaties supreme laws of the land, the Executive and the Senate have in many cases, an exclusive power of legislation; which might have been avoided, by proper distinctions with respect to treaties, and requiring the assent of the House of Representatives, where it could be done with safety."); also in PAMPHLETS ON THE CONSTITUTION OF THE UNITED STATES, supra note 77, and in $2 \mathrm{H}$. STORNG, THE COMPLETE ANTI-FEDERALIST 2.2 (1981).

84. Sentiments of Many, Virginia Independent Chronicle (Richmond, Va.), June 18, 1788 (emphasis 
Complained William Symmes of Massachusetts,

The Senate. Who are the Senate? Look back and you will see that a majority is a quorum. This is fourteen, and two-thirds of fourteen are ten. The President and ten Senators may make treaties ....

Where in God's name did they get this? From reason or from history? I fear, not from the former; and as to the latter, it has not come within my reading in any constitution where a republican form is guarantied. Are we then a commonwealth, and shall we have no voice in treaties? but our own President, or elected King? In four years' time (with good hope of another election,) cannot he pack a sufficient force to enable him to gratify his favorites, or sell his country? If this be not a servile adherence to the pattern of the King's privy Council of Great Britain, I confess I know not what is. ${ }^{85}$

Congress' legislative powers were enumerated, but the treaty power had no specified objects. Opponents in the Pennsylvania Convention objected that the President and Senators could supersede any "power, privilege or liberty of the state governments, or of the people." ${ }^{166}$ Asked the Countryman from Dutchess County, "what security [can we] have for any one right, however sacred or essential, when there is no explicit proviso, that the laws and treaties which may be made, shall not be repugnant to the constitution?"87 A safeguard available in Great Britain was lacking. There, if the King's councillors recommended a treaty that was imprudent or corrupt, or encroached upon legislative powers or liberties, they might be impeached by the Parliament. ${ }^{88}$ But here, the power to advise and consent to the ratification of treaties and "the sole Power to try all Impeachments"89 reposed in the same body. Cried Virginia's Brutus, if a treaty "should be found prejudicial to the interest and honor of the

in original), in 5 H. STORING, supra note 83, at 5.20.3.

85. Letter from William Symmes to Capt. Peter Osgood, Jí. (Nov. 15, 1787) (emphasis added), in 4 HISTORICAL COLLECTIONS OF THE ESSEX INSTITUTE No. 5, at 211-17 (Oct. 1862); also in 4 H. STORING, supra note 83 , at 4.5.2.

86. The Address and Reasons of Dissent of the Minority of the Convention of Pennsylvania To Their Constituents, Pennsylvania Packet and Daily Advertiser (Philadelphia, Pa.), Dec. 18, 1787, in 3 H. STORING, supra note 83, at 3.11.42. Complained the Pennsylvanians, "It is the unvaried usage of all free states, whenever treaties interfere with the positive laws of the land, to make the intervention of the legislature necessary to give them operation. This became necessary, and was afforded by the parliament of GreatBritain." Id. at 3.11.43.

87. Letters from a Countryman from Dutchess County, New York Journal (New York, N.Y.), Dec. 15,1787 , in $6 \mathrm{H}$. STORING, supra note 83 , at 6.6.27.

88. See 1 W. BLACKSTONE, supra note 78, at 249 (2d ed. Oxford 1766, 1st Am. ed. Philadelphia 1771): It is also the king's prerogative to make treaties, leagues, and alliances with foreign states and princes. ... And yet, lest this plenitude of authority should be abused to the detriment of the public, the constitution . . . hath here interposed a check, by the means of parliamentary impeachment, for the punishment of such ministers as from criminal motives advise or conclude any treaty, which shall afterwards be judged to derogate from the honour and interest of the nation.

In the first English edition, Blackstone did not include the qualifying phrase "from criminal motives." Maladministration and misadvice might suffice.

89. U.S. CONST. art. I, $\$ 3, \mathrm{cl} .6$. 
United States, how is punishment to be applied? By impeaching the senate before the senate ...?"90 The treaty power was a part made greater than the whole. "[T] $]$ hough three branches must make the law, two may destroy it." 11 Even freedom of the press was endangered, scathed Cincinnatus; the President and the Senate might chose to make a treaty restricting press attacks on the conduct of governments. ${ }^{92}$

Now these, to be sure, were the voices of opposition, ${ }^{93}$ and they failed to stop the anointment of the new instrument of Union. But the failure of their vote in opposition should not still their voices as an aid to interpretation. Proponents of the Constitution may well have based affirmative votes on the premise that these fears were hysteric, that a President, Senate, and Supreme Court sensitive to constitutional concerns would not allow treaty power to be used in overbearing fashion, that the danger of aristocratic aggrandizement was small and outweighed by the need for effective treaty implementation by the United States to secure our boundaries and position in international commerce.

To take the dissenters at their worst fears and most pessimistic view of the constitutional machinery, to declare by their failure to block ratification that the majority is free to march through with abandon, is to despair ever of the construction of a constitutional consensus. A wise Representative from Georgia-one Abraham Baldwin-later remarked that a constitutional agreement must leave some things unsettled, to be made certain by practice, or else by amendment:

90. Reply to Cassius By Brutus, Virginia Independent Chronicle (Richmond, Va.), May 14, 1788, in 5 H. STORING, supra note 83, at 5.15.1.

American constitutionalists even yet do not agree whether acts not punishable by criminal prosecution can constitute the "high Crimes and Misdemeanors" for impeachment under the Constitution. The issue can be clarified only when one first takes account of the eighteenth century view of federal common law crimes, see supra note 33. The twentieth century's normative disdain for criminal lex non scripta, preferring to restrain prosecutors' power and enlarge citizens' liberty by requiring clear notice of prohibited conduct, may camouflage the eighteenth century's sense that criminality could be measured by moral depravity and harm caused to the commonweal. An act could be criminal and prosecuted even without statutory definition or penalty. See generally P. HOFFER \& N. HULL, IMPEACHMENT IN AMERICA, 1635-1805 (1984); C. BLACK, IMPEACHMIENT: A HANDBOOK 27-33 (1974).

Nor is it established, as might concern critics of treaty power, that Senators are subject to impeachment as "civil Officers of the United States," U.S. CONST. art. II, § 4, or otherwise. Compare J. JAY, FEDERALIST No. 64 (The Senate and the Treaty Power) (Senators' "motive to good behavior is amply afforded by the article on the subject of impeachments") and A. HAMILTON, FEDERALIST No. 66 (The Senate: Further Consideration of the Impeachment Power) (convention "might . . . have had in view the punishment of a few leading individuals in the Senate," if any "prostituted their influence in that body as the necessary instruments of foreign corruption") with F. WHARTON, supra note 6, at 315-16 (Senate's refusal of jurisdiction in impeachment of former Senator William Blount) and P. HOFFER \& N. HULL, supra, at 151-63.

91. Reply to Cassius By Brutus, Virginia Independent Chronicle (Richmond, Va.), May 14, 1788, in 5 H. STORING, supra note 83, at 5.15.1.

92. Essays by Cincinnatus (To James Wilson), Essay I, New York Journal (New York, N.Y.), Nov. 11,1787 , in $6 \mathrm{H}$. STORNG, supra note 83 , at 6.1.5.

93. William Symmes of Massachusetts was later persuaded to vote in favor in the Massachusetts Convention. See 2 THE DEBATES IN THE SEVERAL STATE CONVENTIONS ON THE ADOPTION OF THE FEDERAL CONSTITUTION, supra note 61 , at 174. 
[I] $t$ was not supposed by the makers of it at the time, but that some subjects were left a little ambiguous and uncertain. ... If they could all be agreed in, it would compact the Government. The few that were left a little unsettled might, without any great risk, be settled by practice or by amendments in the progress of the Government. He believed this subject of the rival powers of legislation and Treaty was one of them $\ldots 9^{94}$

Some would conclude this was a necessary uncertainty-forebearing immediate settlement of all points in the Constitution in the interests of reaching a working agreement. As businessmen know better than lawyers, few deals can survive anticipation of every dire hazard and chance of discord; over-anticipation is a fault of pedantry and of distrust. When parties are of relatively equal power, unsettled terms can act to sustain a relationship, by warning each party that much else could be lost by pressing immediate advantage. Mutual acceptance of the hazards of uncertainty argues in favor of a spirit of accommodation in constitutional dispute. The birthgem of Philadelphia should not be assayed by gimlet-eyed partisans seeking victory, else the jewel might fracture.

Foreign affairs power was soon the center of critical national events, in two incidents of state which arrayed the Executive as potential rival to the Congress-in Washington's statement of neutrality and in ratification of the Jay Treaty. Congress' power to declare war and to define and punish offenses against the law of nations, and Congress' claim to have voice in foreign policy were seen at risk in Washington's Neutrality Proclamation of 1793.95 The Proclamation declared that the United States would take no part in the naval and land war between revolutionary France and the First Coalition of European powers. Washington's act was sullied by some as a breach of our 1778 Treaties of Amity and Alliance with France; ${ }^{96}$ in the midst of the American Revolution, we had entered a pact of mutual aid with France, and now were disregarding the same guarantee. The Proclamation was also challenged as invasion of the Congress' power to declare war, ${ }^{97}$ by deciding on war or peace. Washington's action seemed to claim that the President, not the Congress, had the right to set the nation's course in international politics.

The defense given by Alexander Hamilton in the Pacificus essays ${ }^{98}$

94. 5 ANNALS OF CONG., 4th Cong., 1st Sess. 537 (Mar. 14, 1796).

95. Proclamation of Neutrality (Apr. 22, 1793), in 32 THE WRTINGS OF GEORGE WASHINGTON 430 (J. Fitzpatrick ed. 1939).

96. Treaty of Amity and Commerce, signed Feb. 6, 1778, United States-France, 8 Stat. 12, T.S. No. 83; Treaty of Alliance, signed Feb. 6, 1778, United States-France, 8 Stat. 6, T.S. No. 82.

97. U.S. CONST. art. I, \& 8, cl. 11.

98. See A. HAMILTON, Pacificus Nos. I-VII, in 15 The PAPERS OF AleXANDER HaMILTON, supra note 78. Hamilton's writings on foreign affairs power, so infrequently read nowadays, make clear he was at least an intellectual match for John Marshall. He combines Marshall's lucid style with a great erudition in common law and the law of nations-Marshall's logic and Story's authorities in one voice. The Pacificus essays originally appeared in the Gazette of the United States (Philadelphia, $\mathrm{Pa}$.) between June 29 and July 27,1793 . Hamilton was answered by James Madison in the Helvidius essays which appeared in the Gazette 
enlivened Republican fears, for Hamilton reconciled the 1778 treaties with America's neutrality by adopting a sharply counter-revolutionary posture. There was no breach of the 1778 promise because the guarantee of aid by America applied only to defensive wars and only to just wars. France's manifesto in the 1792 National Convention to aid all European wars of rebellion ${ }^{99}$ was a tortious interference, seeking to stir up internal disputes, and deprived France's war of justice and defensive character. ${ }^{100}$

Hamilton also made famous a Federalist theory of broad Executive power. The President was not limited to the particular functions qualified in Article II, section 2 of the Constitution. Rather, the opening lines of Article II, section 1 , vested "the EXECUTTVE POWER" in the President, ${ }^{101}$ and this was a "comprehensive grant." 102 The construction of public treaty obligations in international politics was not the province of the legislature ${ }^{103}$ nor of the judiciary. ${ }^{104}$ Rather it fell to the Executive in its various capacities,

as the organ of intercourse between the Nation and foreign Nations-as the interpreter of the National Treaties in those cases in which the Judiciary is not competent, that is in the cases between Government and Government-as that Power, which is charged with the Execution of the Laws, of which Treaties form a part-as that Power which is charged with the command and application of the Public Force. ${ }^{105}$

Presidential power included transforming international obligations into domestic rules. The President's Proclamation informed foreign countries of American neutrality, disclaimed responsibility for any citizens' acts in aid of a belligerent, and proclaimed citizens' obligation to conform their conduct to American neutrality. In the Neutrality Proclamation, Washington embraced a theory of federal common law crimes or, more properly, of federal crimes under the law

of the United States between August 24 and September 18, 1793; also in 15 THE PAPERS OF JAMES MADISON, supra note 57, at 66-74, 80-87, 95-103, 106-10, 113-20.

99. See Decree of the National Convention (Nov. 19, 1792), supra note 32.

100. See A. Hamlton, Pacificus No. II, in 15 The PAPERS of AleXANDER Hamilton, supra note 78 , at 55-63.

101. A. Hammton, Pacificus No. $I$, in id. at 39 (emphasis in original).

102. Id. Said Hamilton, "[T]he difficulty of a complete and perfect specification of all the cases of Executive authority would naturally dictate the use of general terms-and would render it improbable that a specification of certain particulars was designed as a substitute for those terms ...." Id.

103. For Hamilton:

The Legislative Department is not the organ of intercourse between the UStates and foreign Nations. It is charged neither with making nor interpreting Treaties. It is therefore not naturally that Organ of the Government which is to pronounce the existing condition of the Nation, with regard to foreign Powers, or to admonish the Citizens of their obligations and duties as founded upon that condition of things.

Id. (emphasis in original).

104. Pronouncing on neutrality "is foreign to the Judiciary Department of the Government. The province of that Department is to decide litigations in particular cases. ... It has no concem with pronouncing upon the external political relations of Treaties between Government and Government." Id. at 38.

105. Id. (emphasis in original). 
of nations. Any American violating neutrality was to be prosecuted, ${ }^{106}$ though Congress had passed no statute defining neutrality or creating such a criminal offense. Hence the President assumed a power to interpret treaty obligations and the law of nations-in deciding upon the Executive's own actions in American foreign policy and in setting out and enforcing prohibitions for citizens' conduct. ${ }^{107}$

Even if one held a modest theory of Executive power, limited to the enumerated duties of Article II, section 2, warned Hamilton, the same competence would flow. The President has the duty to "take care that the laws be faithfully executed," and "to execute the laws must first judge for himself of their meaning." 108 The law of the land includes "Treaties and the laws of Nations," and so the President was obliged to set out his construction of their requirements. ${ }^{109}$ The Proclamation of Neutrality did not trespass on the Congress' power to declare war, for the President acted merely to execute the country's obligations under the law of nations.

To our modern ears, Hamilton's defense does not explain whether or when the President's interpretation of treaties and the law of nations should be final. It does not explain what the role of the Senate might be in interpreting treaties; though the Senate does not share in the power of execution, the Senate's part in future pact-making may seem to give an especial interest in monitoring current observance. ${ }^{110} \mathrm{But}$ a doctrine of Presidentially-determined "political questions" in public law interpretation may have seemed additionally to beckon when the Supreme Court Justices told Washington a few weeks later that they could not give him advice on questions under the law of nations concerning the use of American ports by French privateers. ${ }^{111}$ That event is normally celebrated as a protection of independence for Article III courts, and so it is,

106. Said Washington's Proclamation, "I have given instructions to those officers to whom it belongs, to cause prosecutions to be instituted against all persons, who shall, within the cognizance of the Courts of the United States, violate the law of nations, with respect to the powers at war, or any of them." Proclamation of Neutrality (Apr. 22, 1793), in 32 THE WRITINGS OF GEORGE WASHINGTON, supra note 95, at 430-31.

107. Gideon Henfield was indicted in 1793 for violating the duties of neutrality under the law of nations, and violating American treaties of peace and amity with European powers, following his enlistment on a French privateer. He was acquitted by the jury. See Henfield's Case, 11 F. Cas. 1099 (C.C.D. Pa. 1793) (No. 6,360); also in F. WHARTON, supra note 6, at 49. Only later, in 1794, did Congress pass a Neutrality Act that forbade Americans from foreign privateering. See An Act in addition to the act for the punishment of certain crimes against the United States, 1 Stat. 381 (June 5, 1794).

108. A. HAMIITON, Pacificus No. I, supra note 78 , at 43.

109. Id.

110. And insofar as the Executive's understanding of a treaty is given deference in judicial interpretation because the President 'knows what he meant to accomplish' in ratifying a pact, the same reason would give weight to Senate understanding.

111. Letter from Chief Justice John Jay and Associate Justices to President George Washington (Aug. 8, 1793), in 3 THE CORRESPONDENCE AND PUBLIC PAPERS OF JOHN JAY 488 (H. Johnston ed. 1890 \& reprint 1970); see also Letter from Secretary of State Thomas Jefferson to Chief Justice John Jay and Associate Justices (July 18, 1793), in 6 THE WRTINGS OF THOMAS JEFFERSON, supra note 18, at 351; A. Hamilton, Draft of Questions to Be Submitted to Justices of the Supreme Court, in 15 THE PAPERS OF ALEXANDER HAMLTON, supra note 78, at 111. 
in one sense. But it also enormously magnified the law-making ability of the Executive. For it allowed the President to claim necessity in acting on his own understanding in execution of international law, and, whenever divergent voices would embarrass national interest, left the courts to follow the President's suit or abstain. ${ }^{112}$ In delay, the courts lost the role of law interpreter. So, too, when critics complained that the President's Proclamation of Neutrality constrained the Congress' power to declare war, Hamilton countered that the President had a duty to execute the law and to set forth the country's obligations under the law of nations. It did not matter that the action might constrict the House and Senate in the later exercise of the war power; the President "may establish an antecedent state of things which ought to weigh in legislative determinations."113 This may seem a solipsistic view of the President's duties. Where Presidential action may overlap Congressional powers, a President prudently would consult with the House and Senate before embarking. But Hamilton will argue only what he must do. We will see Hamilton's theory of broad Executive power revived in the Robbins affair, especially in John Marshall's apologia.

The second great crisis concerning treaty power followed ratification of the Jay Treaty ${ }^{114}$ - an unpopular document which ultimately buried John Jay's ambition to be President. The treaty was denounced from the start as an unwise British concoction, and even the method of its birth seemed to mimic aristocratic government. The text of the Jay Treaty was not disclosed to the public until July 1,1795 , a week after the Senate voted in executive session to consent to ratification. ${ }^{115}$ The text was obtained and published by the Republican newspaper editor Benjamin Franklin Bache in the Philadelphia Aurora. Clamorous public meetings and newspaper polemics followed throughout the summer of

112. It is the province of the judiciary to say what the law is, and so we have struggled endlessly with the doctrine of "political questions." Some writers have tried to explain the limits of judicial power to find law in constitutional settings as a matter of the textual commitment of particular decisions to a non-judicial branch, see Wechsler, Toward Neutral Principles of Constitutional Law, 73 HARV. L. REV. 1, 7-9 (1959); cf. Henkin, Is There A "Political Question" Doctrine?, 85 YALE L.J. 597 (1976). One genus of political questions in international law may beckon when the only textual commitment is highly general: the President's duty to execute the law, to receive ambassadors and other public ministers, and to serve as commander-in-chief. Through exercise of these powers, the President may establish "an antecedent state of things" and courts are left to the damnifying choice of raising divergent national voices, remaining still, or following the President's lead. We may even understand the rule of The Paquete Habana, 175 U.S. 677 (1900), in light of this. Though the law of nations be paramount, a "controlling Executive act" limits a court's faculty to act upon the law of nations in its judicial decisions; the President is silently taken to have a law-finding faculty of his own in questions of public international law; the President's action is not followed despite illegality; rather it is assumed to be legal where there must be only one standard.

113. A. HAMIILTON, Pacificus No. I, supra note 78, at 42 .

114. Treaty of Amity, Commerce and Navigation, United States-Great Britain, 8 Stat. 116, T.S. No. 105 (signed at London, Nov. 19, 1794; submitted to Senate, June 8, 1795; resolution of advice and consent voted by Senate on condition, June 24, 1795; ratified by United States, Aug. 14, 1795; ratifications exchanged at London, Oct. 28, 1795; proclaimed, Feb. 29, 1796).

115. The handiwork of Grenville and Jay received Senate approval by the barest margin. The vote on the Jay Treaty was 20 to 10. See 4 ANNALS OF CONG., 3d Cong., 2d Sess. 862 (June 24, 1795). 
1795 , seeking to dissuade Washington from ratifying the treaty. ${ }^{116}$ Upon Washington's ratification, treaty opponents turned to the House of Representatives.

The Jay Treaty failed to accomplish many of the objects desired by Federalists and Republicans. ${ }^{117}$ It did not enact the maxim of armed neutrality, that "free ships make free goods," and hence suffered British seizures of French merchandise under American carriage. ${ }^{118}$ The treaty did not address Great Britain's claimed right of impressment under the doctrine of perpetual allegiance, which held a British-born seaman was liable to military service even though he claimed new American nationality. ${ }^{119}$ It failed to compensate for slaves taken by the British in the 1782 evacuation. The treaty also affronted the House's sense of legislative scope by its extensive regulation of foreign commerce and tariff policy, with terms for foreign commerce and shipping that Republicans denounced as lacking reciprocity.

116. The resolutions of town meetings and the newspaper essays of Republicans such as Cato (Robert Livingston), Cinna, and Decius attacking the Jay Treaty are collected in THE AMERICAN REMEMBRANCER (Mathew Carey ed. Philadelphia 1795), available in the American Antiquarian Society's extraordinary microfiche series, EARLY AMERICAN IMPRINTS, 1639-1800, indexed as Evans No. 28389, see 10 C. EVANS, AMERICAN BIBLIOGRAPHY (American Antiquarian Society 1929). The essays of Alexander James Dallas assailing Features of Mr. Jay's Treaty, and the Federalist defense by Curtius (Noah Webster, Jr., and James Kent), are also reprinted in pamphlet form, see TREATY OF AMTTY, COMMERCE, AND NAVIGATION (Mathew Carey ed. Philadelphia 1795), available in EARLY AMERICAN IMPRINTS, 1639-1800, supra (Evans No. 29752). These constitutional essays remain an important source for understanding Republican suspicions of treaty power, and for placing the debate of our own time concerning the possible limits of treaty power. (For example, the issue in Edwards v. Carter, 580 F.2d 1055 (D.C. Cir.), cert. denied, 436 U.S. 907 (1978) - whether United States' claims to territory in the Canal Zone could be conceded by treaty, despite Congress' power to make regulations for the disposition of United States property, U.S. CONST. art. IV, $\S 3$, cl. 2-is anticipated in the Jay Treaty debate over settling the northern border.)

117. Standard accounts of the Jay Treaty debate include J. COMBS, THE JAY TREATY: POLITICAL BATTLEGROUND OF THE FOUNDING FATHERS (1970); S. BEMIS, JAY'S TREATY: A STUDY IN COMMERCE AND DIPLOMACY (1962); J. CHARLES, THE ORIGINS OF THE AMERICAN PARTY SYSTEM 91-140 (1956).

118. Armed neutrality was proposed by Catherine of Russia in 1780 , with an increased sense of territoriality toward vessels of national flag, disputing Britain's claim of a right to search a neutral vessel in wartime for contraband and for goods belonging to the enemy. In Anglo-American relations, Article 17 of the Jay Treaty guaranteed neutral shipowners that carriage of noncontraband enemy goods would not lead to forfeiture of the vessel or other cargo, but acknowledged that neutral vessels could be detained on "just suspicion" of carrying any enemy property. See 18 THE PAPERS OF ALEXANDER HAMIITON, supra note 78, at 437 \& n.60; THE ARMED NEUTRALITIES OF 1780 AND 1800, at 273-74, 281 (J. Scott ed. 1918). Hamilton counseled Washington that the maxim of armed neutrality was not yet part of the law of nations, and could become so only "by common consent or by long and general usage." See A. Hamilton, Remarks on the Treaty of Amity Commerce and Navigation lately made Between the United States and Great Britain (July 9-11, 1795), in 18 THE PAPERS OF ALEXANDER HAMLTON, supra note 78, at 438.

119. Allegiance was seen by Britain as a natural relationship between king and subject, and as a political contract exchanging allegiance for protection, enforceable by the disappointed national party. See Calvin's Case, 7 Co. Rep. 1 (1609); 1 W. BLACKSTONE, supra note 78, at 357-58 (2d ed. 1766) ("Natural allegiance is such as is due from all men born within the king's dominions . . . . For, immediately upon their birth, they are under the king's protection; ... during their infancy[ ] they are incapable of protecting themselves. Natural allegiance is therefore a debt of gratitude; which cannot be . . cancelled, or altered, by any change of time, place, or circumstance, nor by any thing but the united concurrence of the legislature"). The law's reluctance to constrain personal liberty in contractual performance is still more than a half century away, even in ordinary settings. 
John Jay's 1794 Treaty of Amity, Commerce, and Navigation engaged the sensibilities of the House by pledging the United States would fund any British debts obstructed by state legislation or state judicial action. ${ }^{120}$ The treaty's pledge challenged the House of Representatives in the one competence reserved to the House alone, other than initiating impeachment-the origination of bills of revenue. Article I, section 7, clause 1 of the Constitution provides that "All Bills for raising Revenue shall originate in the House of Representatives." Article I, section 9, clause 7 of the Constitution provides that "No Money shall be drawn from the Treasury, but in Consequence of Appropriations made by Law."

A Very High Federalist could seek to side-step the House in both these rules. Treaties are a form of "Law" by Article VI, and if so considered, could appropriate monies with only spiritual violence to the terms of Article I, section 9, clause 7. "Bills" for raising Revenue belong to the House, but appropriations could be made from revenue already on hand. And, the Very High Federalist might dare, perhaps "Bills" are only one method for raising revenue: treaties which do not originate by bill also might settle tariffs and taxes. Republicans anticipated both theories in their criticism of the Jay Treaty. Federalists in the Jay Treaty debate confined themselves to the tamer argument that the House had a constitutional duty to vote appropriations for the treaty following ratification. ${ }^{121}$ But some Republicans saw these other High Federalist theories as the real underpinning. The ground for the Jay pledge - that states' obstruction of debt recovery violated the earlier peace treaties and the law of nations ${ }^{122}$ - symbolized the repudiation of popular authority in foreign policy. The fiscal burden of the debt guarantee was greatly feared.

The reaction to the Jay Treaty in the House of Representatives demonstrated the rift, never to be cured, over the House's role in foreign affairs. When the treaty was taken up by the House to consider Washington's request for appropriations, the first riposte was a motion by Congressman Edward Livingston of New York demanding the instructions given to Plenipotentiary John Jay and the record of negotiations. Hamilton and Washington might believe the House of Representatives was bound, as the United States was honor-bound, to implement the ratified treaty terms. Pacta sunt servanda. But Livingston, Jefferson, and other Republicans insisted that the power to decide upon appropriations allowed the House to re-examine the constitutionality and even wisdom of treaty undertakings. Jefferson wrote to Republican James Monroe:

120. Treaty of Amity, Commerce and Navigation, Nov, 19, 1794, United States-Great Britain, art. 6, supra note 114.

121. See, e.g., A. HAMIIION, The Defence No. 38, in 20 THE PAPERs OF ALEXANDER HAMIITON, supra note 78 , at 21 .

122. See Preliminary Articles of Peace, signed Nov. 30, 1782, United States-Great Britain, arts. 4 \& 5, 8 Stat. 54, 56, T.S. No. 102; Definitive Treaty of Peace, signed Sept. 13, 1783, United States-Great Britain, arts. 4 \& 5, 8 Stat. 80, 82, T.S. No. 104 . 
we concieve the constitutional doctrine to be that tho' the P[resident] $\&$ Senate have the general power of making treaties yet whenever they include in a treaty matters confided by the constitution to the three branches of legislature, an act of legislation will be requisite to confirm these articles, and that the $\mathrm{H}$. of Repr. as one branch of the legislature are perfectly free to pass the act or to refuse it, governing themselves by their own judgment whether it is for the good of their constituents to let the treaty go into effect or not. [O]n the precedent now to be set will depend the future construction of our constitution; and whether the powers of legislation shall be transferred from the P[resident,] Senate \& H. of R. to the P[resident, ] Senate \& Piamingo ${ }^{123}$ or any other Indian, Algerine or other chief. [I]t is important that the first decision is to be in a case so palpably atrocious as to have been predetermined by all America. ${ }^{124}$

Washington refused to turn over the record of negotiation, arguing that secrecy in treaty-making forbade such a precedent. The House had never before controverted the binding effect of treaties, put Washington; the Constitutional Convention had clearly settled House exclusion from treaty-making, and the only other possible pertinence of the papers was for impeachment. ${ }^{125}$ Washington's claim inspired angry retort from Madison and other Republicans. Complaining of Washington's reliance on a Convention record all had agreed would remain secret, ${ }^{126}$ Madison also disputed Washington's interpretation. James Wilson's proposal in the Philadelphia Convention to include the House in treaty-making had been defeated because of its overbreadth. Its defeat still permitted the conclusion that some selected treaties required legislative concurrence. Even assuming

the record of the Convention to be the oracle that ought to decide the true meaning of the Constitution, what did this abstract vote amount to?

123. Piamingo was leader of the Chickasaw Nation. A treaty signed by Virginia commissioners with Piamingo in 1783 removed Chickasaw claims to lands in the southern watershed of the Cumberland River. The treaty helped to advance the Iand speculations of William Blount's North Carolina land company, in which two of the Virginia commissioners privately had invested. Perhaps inadvertently, Jefferson thus gave allusion to Republican fears of corruption in any form of government by a small number of men. See T. ABERNETHY, WESTERN LANDS AND THE AMERICAN REVOLUTION 259-62 (1937); The Chickasaw Treaty, 1 DICTIONARY OF AMERICAN HISTORY 361 (James Truslow Adams ed. 1961). Piamingo also signed a treaty with the United States in 1786, 7 Stat. 24, and visited Philadelphia in 1794 to meet with President Washington. See 33 THE WRITINGS OF GEORGE WASHINGTON, supra note 95 , at $423 \mathrm{n}$.

124. Letter from Thomas Jefferson to James Monroe (Mar. 21, 1796), in JEFFERSON PAPERS, SERIES 1, supra note 18, roll 20, frame 17092; also in 7 THE WRITINGS OF THOMAS JEFFERSON, supra note 18, at $67-68$ (with minor textual variations).

125. See Message to the House of Representatives (Mar. 30, 1796), in 13 THE WRITINGs OF GEORGE WASHINGTON 177 (W. Ford ed. 1892).

126. Madison's notes of the debate at Philadelphia were not published until after his death. The Journal kept by Convention secretary William Jackson was published only in 1819. See JOURNAL, ACTS AND PROCEEDINGS OF THE CONVENTION, AsSEMBLED AT PHILADELPHIA, MONDAY, MAY 14, AND DisSOLVED MONDAY, SEPTEMBER 17, 1787, WHICH FORMED THE CONSTITUTION OF THE UNITED STATES (Boston 1819); see also The Sources, 1 THE DOCUMENTARY HISTORY OF THE RATIFICATION OF THE CONSTITUTION, supra note 72 , at $30-38$. 
... [F]or [the treaty power critics] do not contend that no Treaty shall be operative without a law to sanction it; on the contrary, they admit that some Treaties will operate without this sanction; and that it is no further applicable in any case than where Legislative objects are embraced by Treaties. ${ }^{127}$

Madison argued in favor of accommodation of the House, a prospect less attractive to those who feared that America's true interests in the world would be overlooked by men distracted by domestic political purpose. Still Madison might suggest:

if the spirit of amity and mutual concession from which the Constitution resulted was to be consulted on expounding it, that construction ought to be favored which would preserve the mutual control between the Senate and House of Representatives, rather than that which gave powers to the Senate not controllable by, and paramount over those of the House of Representatives, whilst the House of Representatives could in no instance exercise their powers without the participation and control of the Senate. ${ }^{128}$

When the windstorm was over, the House debated the merits of the Jay Treaty without the record of diplomatic negotiations, and narrowly voted an appropriation for the treaty, by a three vote margin, 51 to $48 .{ }^{129}$

As an incident of state practice, ${ }^{130}$ the Jay Treaty debate is not tractable. Each side staked its constitutional claim, and denied the other's. The House exhaustively debated the merits of the Jay Treaty-a debate that Washington and Hamilton regarded as extraordinary arrogation-and claimed a right to refuse appropriations. ${ }^{131}$ Yet the House did vote the funds. The House may only have concluded the Treaty was prudent after all, retaining full faculty to refuse funds in another case. Yet the Representatives may also have been swayed by the need to preserve good faith and reputation in treaty negotiations, an argument that comes close to Washington and Hamilton's constitutional

127. 5 anNals OF CONG., 4th Cong., 1st Sess. 776 (Apr. 6, 1796).

128. Id. at 780 .

129. Id. at 1291 (Apr. 30, 1796); Act of May 6, 1796, 1 Stat. 459.

130. Among nations, long-standing practice may give rise to rules of customary international law, where practice is accompanied by a sense of obligation. Between coordinate branches of government, we may wish to conclude, institutional practice accompanied by a sense of obligation can create a "customary" constitutional law.

131. A House resolution, approved 57 to 35 , staked the right to refuse execution of treaties trenching on legislative powers:

[T] he House of Representatives do not claim any agency in making Treaties; but, that when a Treaty stipulates regulations on any of the subjects submitted by the Constitution to the power of Congress, it must depend, for its execution, as to such stipulations, on a law or laws to be passed by Congress. And it is the Constitutional right and duty of the House of Representatives, in all such cases, to deliberate on the expediency or inexpediency of carrying such Treaty into effect, and to determine and act thereon, as, in their judgment, may be most conducive to the public good.

5 ANNALS OF CONG., 4th Cong., 1st Sess. 771, 782 (Apr. 6-7, 1796). 
claim. International breach of promise would not be excused by domestic difference. The very proponent of House participation in treaty-making, James Wilson, taught in his Pennsylvania law lectures that democratic polities have an obligation to conform their free will to the law of nature and nations, ${ }^{132}$ and pacta sunt servanda was the first maxim of natural society and the community of nations. ${ }^{133}$ As individuals we may be tempted to deviate from rule as if to announce our freedom, and so too legislative bodies may seek to demonstrate their liberty, but in Wilson's eyes, democracy's first calling is to quell arrogance of will, in favor of natural rules of justice.

Strange to say, in the boxing over the Jay Treaty, few blows landed on Article 27 and its provision for the foreign delivery of murderers and forgers. Representative William Giles, who was a consistent critic of the Treaty, only remarked: "The 27th article provides for reciprocally giving up certain fugitives from justice; which was not objectionable."134 Jefferson made no immediate comment, so far as his published writings reveal. ${ }^{135}$ Hamilton reviewed the Jay Treaty for President Washington, ${ }^{136}$ who was wary of the public reaction and wavered whether to ratify the Treaty following the Senate's approval; $; 137$ Hamilton commented on Article 27, "These articles [26 \& 27] need no particular comment. They are liberal and equitable and interfere with no interest or duty." ${ }^{138}$ In the "Camillus" essays-Alexander Hamilton and Rufus King's

132. Perhaps especially democratic polities, since the people claim their sovereignty by virtue of the law of nature. See J. WILSON, Of the Law of Nations, in 1 THE WORKS OF JAMES WILSON, supra note 37, at 153:

The law of nations is the law of sovereigns. In free states, such as ours, the sovereign or supreme power resides in the people. In free states, therefore, such as ours, the law of nations is the law of the people. ... I mean not that it is a law made by the people, or by virtue of their delegated authority .... I mean that, as the law of nature, in other words, as the will of nature's God, it is indispensably binding upon the people, in whom the sovereign power resides; and who are, consequently, under the most sacred obligations to exercise that power . . . in a manner agreeable to those rules and maxims, which the law of nature prescribes to every state, for the happiness of each, and for the happiness of all.... But, unfortunately, as there have been and there are, in arbitrary governments, flatterers of princes; so there have been and there are, in free governments, flatterers of the people.

133. Id. at 166: "A state, which violates the sacred faith of treaties, violates not only the voluntary, but also the natural and necessary law of nations; for ... by the law of nature, the fulfillment of promises is a duty as much incumbent upon states as upon men."

134. 5 ANNALS OF CONG., 4th Cong., 1st Sess. 1044 (Apr. 18, 1796).

135. Jefferson's early views on the judicial isolation necessary to a republican government, described more fully at page 321 infra, were not tendered publicly against the Jay Treaty during the Senate ratification debate or the House debate on appropriations.

136. A. Hamilton, Remarks on the Treaty of Amity Commerce and Navigation lately made Between the United States and Great Britain (July 9-11, 1795), in 18 THE PAPERS OF ALEXANDER HAMIITN, supra note 78 , at 404 .

137. See Letter from George Washington to Alexander Hamilton (July 3, 1795), in 18 THE PAPERS OF ALEXANDER HAMLTON, supra note 78, at 398 ("my wishes are, to have the favorable, and unfavorable side of each article stated, and compared together; that I may see the bearing and tendency of them: and ultimately, on which side the balance is to be found.") (emphasis in original). The Senate gave its advice and consent on June 24, 1795; Washington ratified the treaty on August 14, 1795. See 2 TREATIES AND OTHER INTERNATIONAL ACTS OF THE UNITED STATES OF AMERICA 245 (H. Miller ed. 1931).

138. A. Hamilton, Remarks on the Treaty of Amity Commerce and Navigation lately made Between 
long and rather brilliant Defence of the Jay Treaty in newspaper polemics ${ }^{139}$ -Article 27 was lauded as a rule of "peculiar worth between nations whose territories are contiguous," preventing the escape of "the perpetrators . . of atrocious crimes." Said Camillus, the Article evidenced "a caution due to the rights of individuals." ${ }^{140}$ The American Minerva praised Article 27 as "a regulation that humanity and commerce demand to be established between all nations, since by the ref[u]sal of Refuge to murderers and forgers, we add security to life and property." 141 A "temperate enquir[er]" praised the purpose of Article 27, even while admitting constitutional doubt; sending murderers back for trial was the "prevention of moral evil"; the Article was "founded in perfect reciprocity and equality" and "if it can be reconciled to the federal constitution ... must receive our cordial approbation."142 Following Senate ratification, the Congress did not pass implementing legislation for Article 27, but it appears they were not asked to.

But one Republican gave brash notice of politics or principle. Revolutionary poet become Republican editor, Philip Freneau saw invasion of the province of popular government. In a "Letter from a gentleman in Virginia, to his friend in Baltimore," Freneau alarmed of Article 27:

Do we not see in the proposed treaty ... the very constitution itself in the most fundamental parts torn to pieces! The trial by jury given up! and even the place of trial of our citizens surrendered to Great Britain !! ! Contrary to the declaration of the constitution, which expressly says, of crimes not committed within any state, that "the trial shall be at such place or places as the Congress may by law have directed."143

the United States and Great Britain (July 9-11, 1795), in 18 THE PAPERS OF ALEXANDER HAMILTON, supra note 78 , at 450 .

139. Hamilton's twenty-eight Camillus essays, entitled The Defence, are reproduced in $18,19 \& 20$ THE PAPERS OF AleXANDER HAMmTON, supra note 78. Rufus King drafted an additional ten Camillus essays which were edited by Hamilton. The King essays are indexed but not reproduced in Syrett's otherwise magnificent edition of THE PAPERS OF ALEXANDER HAMILTON. However, the King essays are available in the Library of Congress Hamilton Papers (manuscripts), and were published in The Herald: A Gazette for the Country (New York, N.Y.), Nov. 14, 18, 25, 28, Dec. 2, 5, 9, 23, 26, 1795. King's essays also were reprinted in THE AMERICAN REMEMBRANCER (Mathew Carey ed. Philadelphia 1795), available in EARLY AMERICAN IMPRINTS 1639-1800, supra note 116 (Evans No. 28389).

140. The Defence No. 35, in 3 THE AMERICAN REMEMBRANCER, supra note 139, at 251-52; originally published in The Herald: A Gazette for the Country (New York, N.Y.), Dec. 26, 1795; attributed to Rufus King in 19 THE PAPERS OF ALEXANDER HAMILTON, supra note 78, at 516. The Article 20 provision, that no asylum should be given to pirates, also appears to have been largely unchallenged; no comment from Hamilton, Jefferson, or any member of the House or Senate. Hamilton adverted only to criticism of Article 21 which permitted each country to punish as a pirate any citizen or subject of the other who accepted a foreign commission to act as a privateer. See The Defence No. 37, in 20 THE PAPERS OF ALEXANDER HAMILTON, supra note 78, at 14.

141. American Minerva (New York, N.Y.), July 4, 1795, at 3, col. 5; also in New Jersey State Gazette (Trenton, N.J.), July 28,1795 , at 1 , col 3 (with slight textual variations).

142. Remarks on the Treaty of Amity, Commerce and Navigation, 3 THE AMERICAN REMEMBRANCER, supra note 139 , at 302 .

143. Jersey Chronicle (Mount Pleasant, N.J.), Aug. 22, 1795, at 144, cols. 2-3 (emphasis in original) (citing U.S. CoNST. art. III, $\S 2$, cl. 3). 
One should not fear the President's act of ratification, for popular remedies lay elsewhere.

[W] hy so much dread of a ratification by the President? Why so much petitioning of him? Can any citizen enlightened by the constitution of the United States imagine that his signature will finish the business[?] $]^{144}$

The citizen's recourse lay first in Congress, especially in the House.

That Congress will approve of the treaty and grant such supply [of appropriations], we need not fear, for "going immediately from the people they will carry with them a full knowledge of the existing temper and sensibility of their constituents, and will thus be taught to vindicate their rights with firmness." 145

If Congress lacked resolve, Freneau assayed, resistance could still be mobilized through the immediate democracy of the public press. ${ }^{146}$

\section{WILLIAM BRIGSTOCK AND A NEW JERSEY JURY}

It is the occasion to return to our immediate drama, reducing insurrection and asylum to the fate of real men, and revolutionary self-conception to the test of decision. We will see two publicly-watched arrests that end at opposite poles. In 1798, William Brigstock and two other defendants from the Hermione are tried by a New Jersey jury and acquitted, and extradition to the British is deflected by a "Republican" reading of the treaty. In the second, in 1799, Jonathan Robbins is examined by a South Carolina judge, and, under a new reading of the treaty by the same Presidential Administration, is sent back to British justice and a sudden death. Why these two episodes unfold so differently-whether it was accident, cynical foreign politics by Federalists seeking

144. Id. (emphasis in original).

145. Id. (emphasis in original).

146. We will see Philip Freneau bobbing to the surface throughout the Robbins affair. Madison's college classmate and lifelong friend, Jefferson's protegé in the early 1790's in editorship of the Republican National Gazette, proprietor of the short-lived Jersey Chronicle - from the first Philip Freneau is a vehement critic of any British connection, outraged by impressment and English naval tyranny, see infra page 283. His brother Peter Freneau provides the first newspaper coverage of the Robbins decision in South Carolina, see infra page 323. Philip bursts forth in the Philadelphia press under the pseudonym "Robert Slender," attacking Adams and the Federalists for Robbins' death. The poetic excess of the Robbins affair may be compared to Philip Freneau's patriotic verse. See PHILIP FRENEAU, POEMS ON SEVERAL OCCASIONS (Monmouth, N.J. 1795).

See also THE PROSE OF PHIIIP FRENEAU (P. Marsh ed. 1955); M. AUSTIN, PHILIP FRENEAU, THE POET OF THE ReVOlution (1901); L. LEARY, THAT RASCAL FRENEAU (1941); J. AXELROD, PHILIP FRENEAU, CHAMPION OF DEMOCRACY (1967); E. EllioTT, Philip Freneau: Poetry of Social Commitment, in REVOLUTIONARY WRITERS 128-70 (1982); Marsh, Philip Freneau and His Circle, [1939] PA. MAG. HIST. \& BIOGR. 37; Editorial Note, Jefferson, Freneau, and the Founding of the "National Gazette," 20 THE PAPERS OF THOMAS JEFFERSON 718 (J. Boyd ed. 1982). 
British favor, sanguinary domestic politics by Federalists setting an example for American sans-culottes, or even principled belief that justice was not served by trials far from the scene of the crime-was the question that fascinated in the eighteenth century. Though Jonathan Robbins is mentioned in passing by most every biography of Adams or Marshall, there has never been a reconstruction of more than the façade of the Robbins affair. With archives no longer guarded by political jealousies, we are in a better position to explore. In these next two sections, our view will change from long lens to close camera. Lawyers and historians share native doubt of legend and repute. Hence, with a warning of nettles and brush, we will venture into the archives.

In the early proceedings raised by the Hermione mutiny, the Adams administration acts on the premise that American criminal process is preferred to foreign, that American juries will decide as justice requires, and (we may conclude) that impressment is a proper cause for shipboard rebellion. Treaty power should preserve broad scope for the premier institution of popular voice, the jury. Yet we will see a split developing even within the Adams administration. While Attorney General Charles Lee of Virginia lauds the voice of the jury, Secretary of State Timothy Pickering of Massachusetts prefers the use of Executive authority to fulfill treaty obligations free from the interposition of American veniremen. Lee will take an "internationalist" view of American criminal law, ${ }_{1}^{147}$ to permit the jury to interpose.

It attracted no notice at the time or since, but the first mutineer from the Hermione found in the United States was seaman Simon Marcus, arrested from the schooner Hannah in Wilmington harbor, Delaware. ${ }^{148}$ These first proceedings turned upon the testimony of Frances Martin, the widow of Hermione bosun William Martin. On February 16, 1798, Mrs. Martin swore before notary William Bleecker in New York City, that she had been on board the Hermione during the mutiny; her husband William Martin, the boatswain, was killed, and she was carried into Caracas "where she had been compelled to go," remaining three weeks before her return to New York on December 26, 1797, on board the Henrietta. ${ }^{149}$

Simon Marcus was one of "seven or eight foreigners who were of the said Frigate's crew," swore Mrs. Martin, and to her "certain knowledge," Marcus "was on board the said Frigate at the time the Officers were murdered." Her full description of Marcus seemed to corroborate her account, the kind of detail that cannot be filled in by the imagination and so lends verisimilitude. ${ }^{150}$ Mrs.

147. See supra pp. 240-241.

148. See Note from British Minister Robert Liston to Secretary of State Timothy Pickering (Feb. 19, 1798), in NOTES FROM THE BRITISH LEGATIONS IN THE UNITED STATES TO THE DEPARTMENT OF STATE, 1791-1906 (National Archives Microfilm Publication M50, roll 3).

149. Affidavit of Frances Martin (Feb. 16, 1798), Attachment to Note from Robert Liston to Timothy Pickering (Feb. 19, 1798), in NOTES FROM THE BRTISH LEGATIONS IN THE UNTTED STATES TO THE DEPARTMENT OF STATE, 1791-1906, supra note 148.

150. See F. KERMODE, What Precisely Are the Facts?, in THE GENESIS OF SECRECY 102 (1979). Marcus 
Martin did not have more to say of Simon Marcus' involvement beyond his mere presence shipboard at the time of the murders. She added, and the reader is requested to note the date of this affidavit, long before Thomas Nash or Jonathan Robbins was a ray in any American judge's eye, that

those Men who were particularly active in murdering the Officers got Possession of the greater part of their Property such as Clothes, Spoons, \& etc., excepting their uniforms, which together with the Tables and Chairs were thrown overboard. That Dick Redman, a West Country man, assisted. Thomas Nash, an Irishman, Jack Smith, a young Man with a fair Complexion, marked with the Small Pox and one [H]arry Croker Gunner's Mate murdered the Husband of Prosecut[rix]. ${ }^{151}$

On February 19, 1798, British Minister Robert Liston wrote Secretary of State Timothy Pickering of Simon Marcus' presence at Wilmington on the Hannah and requested "the American Government will without delay give the necessary orders that he be apprehended and kept in secure custody till an opportunity occur of sending him home for trial."152 Pickering's reply suggests that Adams was early involved in Hermione deliberations, and that the treaty requirement of adequate evidence of guilt was not taken lightly. Liston's note had been "laid before the President," but the accompanying affidavit did not measure up. Mere presence on board during the mutiny was not sufficient for rendition, said Pickering in his February 21 response to Liston. ${ }^{153}$ Liston registered "much regret" at what he chose to call "hesitation on the subject on the part of the American Government"-arguing that the proof was made ample by Marcus' false exculpatory statement denying membership in the Hermione crew, which "should give rise to a suspicion of his criminality strong enough to justify his commitment for trial."154 But Adams' "hesitation" became a final refusal. ${ }^{155}$

was "about five feet, nine or ten Inches in height, slender made, swarthy Complexion, a little marked with the small Pox, with remarkably long and thick black Hair." Affidavit of Frances Martin (Feb. 16, 1798), supra note 149 .

151. Affidavit of Frances Martin (Feb. 16, 1798) (emphasis added), supra note 149.

152. Note from Robert Liston to Timothy Pickering (Feb. 19, 1798), in NOTES FROM THE BRITISH LEGATIONS IN THE UNITED STATES TO THE DEPARTMENT OF STATE, 1791-1906, supra note 148.

153. Note from Timothy Pickering to Robert Liston (Feb. 21, 1798), in DOMESTIC LETTERS OF THE DEPARTMENT OF STATE, 1784-1861 (National Archives Microfilm Publication M40, roll 10). Said Pickering: Your note of the 19th which you handed to me yesterday, with the affidavit accompanying it, I have laid before the President of the United States, by whom I am directed to assure you, that with promptitude he would cause the person named in your note to be apprehended \& delivered up to justice, if the affidavit contained, agreeable to the 27th article of the treaty of amity \&c. "such evidence of criminality, as according to the laws, - would justify his apprehension \& commitment for trial, if the offence had been here committed." But the affidavit states merely that Simon Marcus was on board the Hermione, when the captain \& officers were murdered. Id. (emphasis in original).

154. Note from Robert Liston to Timothy Pickering (Mar. 29, 1798), in NOTES FROM THE BRITISH LEGATIONS IN THE UNITED STATES TO THE DEPARTMENT OF STATE, 1791-1906, supra note 148.

155. On March 29, 1798, Pickering requested Judge Robert Morris to "examine" the three additional men arrested in New Jersey concerning Simon Marcus' part in the "shocking affair" of the Hermione, but 
On March 10, 1798, three more seamen from the Hermione appeared on the brigantine Relief in Perth Amboy harbor, New Jersey. William Brigstock, John Evans, and Joannes Williams were committed to the New Brunswick jail, each sailor using an alias when first arrested. William Brigstock was John Johnston or Johnson, John Evans used the name Michael Campbell, and Joannes Williams was only slightly prolonged to Joannes Williamson. The order of commitment by the New Jersey town recorder and alderman recited the three were arrested "for suspicion of felony"-_"feloniously murdering on the high seas, the captain and other officers of his Britannic Majesty's ship the Hermione" and "piratically delivering up the said ship Hermione to the officers of the king of Spain, now at war with his said Britannic Majesty."156 The commitment relied on the provision of the Jay Treaty's Article 27 that promised the "deliver[y] up to justice" of persons charged with murder "committed within the jurisdiction of either" country, and Article 20, which promised that any pirate "will [be] br[ought] to condign punishment."

On March 13, Pickering asked Attorney General Charles Lee for a legal opinion: Was the available evidence against the Brigstock trio enough to support commitment on murder or piracy? If the proof met the domestic standard for binding a defendant over to stand trial, then extradition should follow, suggested Pickering; the treaty called for the same standard of evidence. ${ }^{157}$

The Brigstock defendants were to cause a deep split in the Cabinet, between High Federalist Pickering and the moderate Federalist Lee. Attorney General

there is no indication that any examination of the Brigstock defendants aided the record against Simon Marcus. See Letter of Timothy Pickering to Judge Robert Morris (Mar. 29, 1798), in DOMESTIC LETTERS OF THE DEPARTMENT OF STATE, 1784-1861, supra note 153.

156. See Order of Commitment (Mar. 10, 1798), reprinted in untitled pamphlet (headed "Circuit Court of the United States, Middle Circuit of the New-Jersey District. The United States (a.) William Brigstock"), available in EARLY AMERICAN IMPRINTS, 1639-1800, supra note 116, Evans No. 38723. The origin of this imprint of the Brigstock record is described at note 401 infra. Brigstock had been "Yeoman of the Sheets" on the Hermione. See D. POPE, supra note 6, at 93; HERMIONE MUSTER BOOK (APR. 7-JULY 7, 1797) (British Public Record Offfice, Adm. 36/12011) (entry no. 622).

157. See Letter from Timothy Pickering to Charles Lee (Mar. 13, 1798) (emphasis added), in PICKERING PAPERS, roll 8, at 203 (F. Allis ed. Massachusetts Historical Society microfiim edition 1966); also in DOMESTIC LETTERS OF THE DEPARTMENT OF STATE, 1784-1861, supra note 153, roll 10 (with minor textual variations):

Will the evidence in the inclosed papers authorize a commitment of the Sailors for murder or piracy committed on board the Hermione British frigate? If it will authorize the Commitment, they may I presume be delivered up to the British Minister, agreeably to the 27th article of the British Treaty. Or if there be no evidence of the murder against these men, will the circumstance of their receiving 25 dollars each from the Spanish Governor of Laguira, on delivering the frigate to him, warrant a charge of piracy?

The British Minister thinks the men, on the present evidence, should be delivered to him. I therefore pray you to examine the papers once more.

Pickering's "once more" suggests he had already put the matter to Lee, but there is no surviving record of an earlier interchange. The evidence relied upon by Pickering in his request is not to be found in the Pickering papers. From the preface of Charles Lee's opinion, see infra note 158, we know it included an affidavit from Yellis Mandeville, master of the brigantine Relief, and an affidavit from William Brigstock. 
Lee chose to narrow the treaty's reach. ${ }^{158}$ In his formal reply, Lee did not laud House legislative powers nor voice concern whether one could arrest citizens or aliens under the treaty without an enabling statute. But he did champion the dignity of American courts and, implicitly, the centrality of the jury. By the 1790 Crimes Act American courts were "fully competent to try and punish persons who commit murder on the high seas, or piracy."159 Brigstock was American, and "it is not to be reasonably expected that his country will not exercise the right of trying him, as he is already in the hands of its officers of justice." 160 The other two defendants, Evans and Williams, might also be Americans, surmised Lee, but even if they were foreign, "I deem it more becoming the justice, honor, and dignity of the United States, that the trial should be in our courts." 161 Lee knew from Pickering's letter that this was a British frigate, a military ship fitted for war, but did not have trouble imagining American criminal jurisdiction extended on board. ${ }^{162}$ The Jay Treaty's promise to deliver murderers who killed "within the jurisdiction of either" nation only "mean[t] their territorial jurisdiction"; the British Minister's requisition was "not authorized by the 27th article." Lee also rejected the possibility of delivery apart from the treaty, citing reasons prescribed by Washington in his Farewell:

158. See Letter from Charles Lee to Timothy Pickering (Mar. 14, 1798), in LETTERS FROM AND OPINIONS OF THE ATTORNEYS GENERAL, 1791-1811 (National Archives Microfilm Publication T326). Lee's opinion was unpublished until 1841, when the House collected and published the Attorney General opinions as an important source of law. See Message from the President of the United States Transmitring Copies of opinions given by the Attorneys General, \&c., which give construction to the public laws not of a temporary character, H. DOC. No. 123, 26th Cong., 2d Sess., at 48-49 (1841). Lee's opinion was republished in 1 OP. ATT'Y GEN. 83-84 (Benjamin Hall ed. 1852).

159. Letter from Charles Lee to Timothy Pickering (Mar. 14, 1798), supra note 158. See Act of Apr. 30, 1790 , §§ 8-10, 1 Stat. 112, 113-14.

160. Letter from Charles Lee to Timothy Pickering (Mar. 14, 1798), supra note 158.

161. Id.

162. Lee's conclusion that the United States might exercise criminal jurisdiction over crimes committed by foreigners on foreign vessels will seem less odd to our modern territorial sensibilities if we recall (1) that foreign ships were made subject by the British to acts of police, even where land-based notions of territory would demand the complete exclusion of foreign sovereigns (e.g., British maritime law claimed the right of a belligerent to visit the merchant and public ships of a neutral to search for contraband); (2) here there was no intrusion by the United States upon the foreign vessel; custody of the offenders was obtained by uncontested means; (3) the rule enforced might be seen as an offense under a universal law of nations, jus gentium as well as jus inter gentes, see supra pp. 240-241; (4) the jurisdiction over foreign nationals might be seen almost as a "pendent jurisdiction," to avoid splitting up the trial of the American and foreign actors in a single criminal transaction. To be sure, Lee did not engage in the painstaking analysis of Wilson, see supra pp. 243-244, concerning the differences between the 1790 Crimes Act and murder and piracy under the law of nations. But the piracy which Pickering asked to have considered was more akin to robbery than to revolution-the act of receiving 25 dollars for turning the ship over to the Spanish, and Brigstock was alleged to be a principal, not an accessory, in the murder of the boatswain. Lee may see American municipal law as implementing a universal law of nations, rather than asserting an aggressive national prescriptive jurisdiction. In this, I disagree with the view of Lee as a "policy-oriented" positivist "flex[ing] the muscles of statehood," to be found in A. RUBIN, THE LAW OF PIRACY, 63 U.S. NAVAL WAR COLLEGE INTERNATIONAL LAW STUDIES 130-31 (1988) ("the full facts are not before us"). 
Suppose it was not the British nation, (whose system of jurisprudence is humane, fair, and just,) but the French, Spanish, or Prussian, that had made the requisition: would it be right to comply with it? I think not; and on a matter of this kind, the same measure should be meted by us to all nations, especially where our own citizens are concerned, and treaties do not require a different rule. ${ }^{163}$

We know from elsewhere that Lee saw a mandatory duty under the unwritten law of nations to deliver heinous offenders, and we have some evidence for his view that a treaty did not displace the unwritten law of nations. Hence the interpretive limits of the Jay Treaty did not exhaust the possibility of delivery of Brigstock and company. But in his earlier views of the subject Lee also had scrupled that the duty to deliver heinous offenders under the law of nations could not be acted upon by the federal government without an enabling statute. Though Lee once apparently acquiesced in Pickering's view that the police powers of state government could be used to make cross-border deliveries, for direct federal action the want of a statute was fatal, over and apart from due regard for the special qualities of American Justice. ${ }^{164}$ There was enough

163. Letter from Charles Lee to Timothy Pickering (Mar. 14, 1798), supra note 158.

164. Lee's views on the conflict between international duty and American constitutional structure were manifest in a 1797 incident. His willingness to use state police powers to fill the gap may be found in a 1796 incident (if we are willing to credit the representations of Mr. Pickering about Lee's views).

In the 1796 foray, the Governor of Canada requested the Governor of Vermont to surrender crossborder fugitives Ephraim Barnes and James Clarkson Freeman, on charges of highway robbery and horsestealing. English Minister Robert Liston and Pickering agreed that the Jay Treaty did not preclude extratreaty deliveries: "[W]hile the reciprocal delivery of murderers \& forgers, is expressly stipulated in the 27th article of our treaty with Great Britain, the two governments are left at liberty to deliver other offenders, as propriety \& mutual advantage shall direct." Letter of Timothy Pickering to President Washington (June 3, 1796) (emphasis added), in PICKERING PAPERS, supra note 157, roll 36, at 86; also in DOMESTIC LETTERS OF THE DEPARTMENT OF STATE, 1784-1861, supra note 153, roll 9 (with minor textual variations). Pickering proposed to "express this opinion to the Governor of Vermont, in order to procure the arrest \& delivery" of offender Barnes, and recorded "The Attorney Gen'l has just called, \& thinks the opinions expressed, to be correct." Id. Pickering capaciously told Liston that "discretion will advise the delivery in cases affecting the great interests of society." Note of "Timothy Pickering to Robert Liston (June 3, 1796) (emphasis added), in PICKERING PAPERS, supra note 157, roll 36, at 84. Washington concurred in the opinion that delivery could be made outside the treaty, Pickering told the Governor of Vermont. See Letter of Timothy Pickering to the Governor of Vermont (June 3, 1796), in PICKERING PAPERS, supra note 157, roll 36, at 85; also in DOMESTIC LETTERS OF THE DEPARTMENT OF STATE, 1784-1861, supra note 153, roll 9.

Pickering also offered what he thought to be the correct procedure for extra-treaty delivery, by common law analogy with the Jay Treaty. "The rule prescribed in the treaty for the delivery of persons charged with murder and forgery will apply to those charged with other offenses-to wit, to be done on such evidence of criminality as by the laws of the place where the fugitive shall be found, would justify his arrest and commitment for trial, if the offence had been there committed." Id. To a Republican observer, Pickering's revelry in the mutual advantages of rendition might suggest the Governor of Vermont was not a necessary actor; perhaps a federal police power could substitute.

In the 1797 incident, Attorney General Lee was skeptical about the solo constitutional capacity of the federal Executive to fulfill even mandatory duties under the law of nations, where they bridged liberty; an extradition under the unwritten law of nations must fail for want of an implementing statute. In January 1797, Pickering put to Lee whether one William Jones, who had entered Spanish Territory and used violence to recover fugitive slaves, could be returned from the United States to Spain. In the temper of Grotius, Rutherforth, and Vattel, see supra note 44, Lee replied that the law of nations placed a mandatory duty on the United States to deliver heinous offenders even without a treaty: 
evidence to commit for trial in New Jersey, in Attorney General Lee's judgment, but extradition under the treaty was not required, and extra-pact delivery should be refused. ${ }^{165}$

Pickering did not tell Liston immediately of Lee's decision, so far as surviving dispatches show. ${ }^{166}$ On March 29, Liston wrote Pickering again, asking for the Brigstock mutineers. Liston rumbled:

[W] hatever may be the ultimate resolution of the President with respect to that man [Marcus], I cannot allow myself to think that there will be a moment's doubt concerning the propriety of delivering up the other three mariners. ... These men have in fact been committed to prison, they have been examined by the magistrates of New Jersey, and they are detained for trial. They have all acknowledged their having been present at the murder of their officers, and I have the honour of enclosing an affidavit of Frances Martin proving that one of them (William Brigstock) took an active part in the atrocious transaction. ${ }^{167}$

In words perhaps too similar to the British Minister's, Mrs. Martin's affidavit recited that Brigstock was "one of the Boatswain's mates" who indeed "took an active part in the Mutiny, and in the murder of the Officers." 163

The next event is quite curious, showing the fracture in the Adams apparat. Despite Attorney General Lee's opinion that the Jay Treaty did not provide for extradition of the Brigstock trio for shipboard offenses and Lee's prior view that one could not deliver fugitives under the law of nations without implementing legislation, Pickering wrote to Judge Robert Morris of the District Court of New Jersey, and requested him "to detain the said William Brigstock until

If a demand were formally made, that William Jones a subject and fugitive from justice, or any one of our own citizens; heinous offenders within the dominion of spain should be delivered to their government for trial and punishment; the United States are in duty bound to comply . . . . See Letter from Charles Lee to Timothy Pickering (Jan. 26, 1797), in LETTERS FROM AND OPINIONS OF THE ATTORNEYS GENERAL, 1791-1811, supra note 158; also in 1 OP. ATT'Y GEN. 68 (Benjamin Hall ed. 1852) (with slight textual variations). The interface between foreign obligation and domestic competence was the problem. One could take a strong view that where there is a mandatory international obligation, the President is bound to assure its fulfiliment under the duty of faithful execution. But Lee preferred to defer to legislative power.

[H]aving omitted to make a law directing the mode of proceeding, I know not how according to the present system, a delivery of such offenders could be effected. To refuse or neglect to comply with such a demand may under certain circumstances afford to the foreign nation, just cause for war, who may not be satisfied, with the excuse that we are not able to take and deliver up the Id. offenders to them. This defect appears to me to require a particular law.

165. The view of Grotius, Rutherforth, and Vattel, that heinous offenders must be delivered or tried in the asylum country, may help account for why Lee was willing to commit the offenders for trial in New Jersey, rather than set them at liberty.

166. See DOMESTIC LETTERS OF THE DEPARTMENT OF STATE, 1784-1861, supra note 153, roll 10 (Mar. 1, 1797-June 29, 1798); PICKERING PAPERS, stupra note 157, roll 8.

167. Note from Robert Liston to Timothy Pickering (Mar. 29, 1798), in NOTES FROM THE BRTISH LEgATIONS IN THE UNITED STATES TO THE DEPARTMENT OF STATE, 1791-1906, supra note 148.

168. Affidavit of Frances Martin (Mar. 26, 1798), enciosed as Attachment to Note from Robert Liston to Timothy Pickering (Mar. 29, 1798), supra note 167. 
the President shall give directions to deliver him to the orders of the British Minister."169 If Adams was drawn into the affair at this stage, ${ }^{170}$ he ruled for Lee, else Pickering lost his nerve, for the Brigstock case proceeded to indictment and trial in Trenton. A grand jury met on Thursday, April 5, 1798, heard Mrs. Martin as the sole witness, and returned indictments the following day in Circuit Court. ${ }^{171}$ Brigstock was charged with murder and piracy in two separate indictments, and the three defendants were charged together with piracy in a third indictment. William Brigstock "not having the fear of God before his eyes, but being moved and seduced by the instigation of the devil," allegedly used "a certain tomahawk of the value of eight pence" to strike a Lieutenant Foreshaw on the right side of the head, inflicting a "mortal bruise" from which he died the next day. Brigstock, Evans, and Williams had "betrayed the trust in them reposed as mariners," "turning pirate," and "run[ning] away with" the vessel, apparel and tackle, worth $\$ 50,000$, a silver tankard worth $\$ 50$, a gold watch worth $\$ 100$, and a silver spoon worth $\$ 2$.

The jurisdictional confusion over acts of violence at sea and agnosticism over sources of law are shown by the pleading of the indictments. Brigstock's piracy and murder were committed "against the peace of the United States, and against the form of the statute in such case made and provided." The legal reference to "the peace of the United States" may only be intended as flourish and surplus, a pleading fiction to ornament a federal offense. Crown offenses were against the king's peace, and early federal indictments may have sought to distinguish public from private injury, or federal and state offenses. But the reference may also have been a charge in the alternative, complaining of conduct that violated both the 1790 Crimes Act and the federal common law or the law of nations. It is startling to suppose that "the peace of the United States" protects the warships of another country upon the high seas, especially an armed British frigate engaged in combat against Spain when the United States has declared neutrality. ${ }^{172}$ Inadvertently, the pleading reminds that one possible motive for enforcement of British naval discipline was to help maintain

169. Secretary of State Timothy Pickering to Judge Robert Morris (Mar. 29, 1798), in DoMESTIC LETTERS OF THE DEPARTMENT OF STATE, 1784-1861, supra note 153. Pickering also advised that the British "made a requisition" of John Evans and Joannes Williams (using their pseudonyms Michael Campbell and Joannes Williamson), and asked Judge Morris "that they may be detained in prison, until the President's final determination concerning them can be had and communicated to you." Id.

170. Adams' papers do not disclose any record of conversation with Lee or Pickering. Adams ceased to keep a diary when he became President in 1797.

171. The filing of the indictment is recounted in the Minutes of the Circuit Court of the United States holden at Trenton in and for the New Jersey District, RECORDS OF THE U.S. DISTRICT COURT FOR NEW JERSEY AND PREDECESSOR COURTS, 1790-1950 (National Archives Microfilm Publication T928, roll 1). The text of the indictments is reproduced in "Circuit Court of the United States, Middle Circuit of the NewJersey District. The United States (a.) William Brigstock," supra note 156.

172. The indictment for piracy charged Brigstock, Evans, and Williams with having run away with an "armed frigate . . . belonging and appertaining to the king of Great Britain . . . against the peace of the United States"-acting "upon the high seas, and out of the jurisdiction of any particular state of the United States, and within the jurisdiction of this court." 
British naval strength, at a time when the depredations of French privateers were so greatly damaging to American shipping. The XYZ affair was then unfolding, and High Federalists and American merchants suggested the United States should rely upon British armed convoys for merchantman protection. ${ }^{173}$

One other sign of jurisdictional anomie came in the description of nationality. Contemporaneous news accounts recite that Brigstock was an American, Evans was an Englishman, and Williams was a Swede. ${ }^{174}$ Yet as if United States citizenship was not yet a fluent phrase, the indictment recorded that Brigstock was "a citizen of the state of New York, one of the United States of America," and "late of the kingdom of Great Britain." Evans and Williams were said to be "late of the kingdom of Great Britain," apparently from the fact of their service on the Hermione. Confusion about nationality and its signs would mark the Jonathan Robbins affair. ${ }^{175}$

With a dispatch more familiar to an age when judges rode circuit, after return of the indictments on Friday, April 6, 1798, trial was had the following Monday, April 9, conducted thirteen hours by Supreme Court Justice Samuel Chase and District Judge Robert Morris. ${ }^{176}$ Mrs. Martin alone appeared for

173. See M. DAUER, THE ADAMS FEDERALISTS 149 \& n.37, 181-82 (1953); Porcupine's Gazette (Philadelphia, Pa), Apr. 3, 1798, at 2, col. 3; Dispatches of British Secretary of State Lord Grenville to Robert Liston (Jan. 27, 1797 \& June 8, 1798), in INSTRUCTIONS TO THE BRIISH MINISTERS TO THE UNITED STATES, 1791-1812, supra note 9, at 128-29, 155 \& n.36.

174. The State Gazette \& New Jersey Advertiser (Trenton, Pa.), Apr. 10, 1798, at 3, col. 2; Gazette of the United States and Philadelphia Daily Advertiser (Philadelphia, Pa.), Apr. 11, 1798, at 3, col. 3.

175. The Hermione's muster books, still preserved in the British Public Record Office (Adm. 36/12009. 12011), record that in the Hermione's five-year cruise out of Chatham, England, fighting the French and Spanish throughout the Caribbean, the crew at times included men born in Norway, Sweden, Denmark, France, Africa, Canada, and (in more than 20 cases) America. Sailors in the Caribbean were, for better or worse, in a common labor pool, transferred from one naval ship to another by momentary order, pressed from merchant to naval service if they were "unprotected" men, even enlisting voluntarily in the naval crews of a foreign sovereign upon the hope of sharing prize money. The Hermione's books show a crew in constant change; during the five-year cruise, 690 men were mustered to fill out a complement of 215 . A high mortality rate (more than 100 men lost to disease, accident, drowning, the bursting of guns, and enemy fire), discharges of several dozen more to hospital or for "unserviceability," and the monthly roster of "Run Men" deserting the ship, added to the Hermione's labor shortage and the necessity of a pick-up crew.

We do not have available the Hermione muster book for the two-and-a-half months before the mutiny of September 22, 1797; the muster books were sent only periodically to England and the Hermione fell sooner into Spanish hands. The last muster book preserved in English archives is for April 7 to July 7, 1797. It records two ordinary seamen named John Evans, one born in Carmarthen, Wales (entry no. 65), and the other with no stated place of birth (entry no. 669). Three John Williamsons are recorded in the crew, but one was discharged (entry no. 28) and another died (entry no. 75) long before the mutiny; the surviving candidate (entry no. 272) has a notation for "Place and County where Born" as Port Royal, a port in Jamaica, though that seems likelier to be a place of embarkation. See HERMIONE MUSTER BOOK (APR. 7, 1797-JulY 7, 1797) (British Public Record Office, Adm. 36/12011). A fourth candidate, John Williams, joined the crew after July 7, but he was first arrested, and then acquitted, in a court-martial in England in March 1799. See Proceedings of a Court Martial of John Williams, et al. (Mar. 13-15, 1799) (British Public Record Office, Adm. 1/5348). Said by American news accounts to be American, Yeoman of the Sheets William Brigstock is recorded in the muster book as a native of Liverpool; he could have emigrated to America after his birth; the muster books have no separate column for "nationality." See HERMIONE MUSTER BOOK (FEB. 10-27, 1797) (British Public Record Office, Adm. 36/12011) (entry no. 622).

176. The case was prosecuted by Lucius H. Stockton, the District Attorney, with William Griffith as counsel. The defense was counselled by Samuel Letre and Aaron D. Woodruff. 
the prosecution; six witnesses appeared for the defense, including one woman. After brief deliberation, the jury acquitted. The circuit court journal records the jury out for an hour; a Philadelphia newspaper said twenty minutes, with a verdict at 1 a.m. ${ }^{177}$

No newspaper account of the trial arguments has come to light. ${ }^{178}$ We can infer something from Pickering's April 13, 1798 draft of a note to the British Minister Liston. Pickering recited that the evidence at trial against Evans and Williams was slender, "prov[ing] only that they were on board, and not that they had any agency in the horrible deed."179 This was the defense theory from the beginning. The defendants already had acknowledged at their bindingover before the Perth Amboy magistrate "that they were on board at the time of the mutiny, but denied being concerned in the horrid acts committed by a part of the crew." 180 Mere presence was the ground on which the Simon Marcus extradition had been refused; one wonders only at the United States District Attorney's decision to allow the case against Evans and Williams to proceed to the jury on the same basis. ${ }^{181}$ Nonetheless, following the acquittals for piracy, Pickering stated that Brigstock would remain in jail for murder as "it is said the proof is strong." 182

It is a familiar belief among trial lawyers that juries may sweep the boards clean of all prosecution claims if any appear overborne. The acquittal of Brigstock for piracy may reflect the jury's dissatisfaction with the proof against Evans and Williams. But one sentence from Pickering's draft of April 13 must be set off by itself in light of what followed; no historian of the Robbins affair has noticed it. After writing that the proof against Brigstock was believed to be strong, Pickering added, "He is a citizen of the United States whose friends live in New York; and probably he was impressed on board the Hermione." 183 It may be that the jury reached the same conclusion, and acquitted in the belief that violence could be used to regain rightful liberty.

In the April 13 note, Pickering finally told Liston of Charles Lee's opinion that extradition could not proceed. Lee and "other law characters whose opin-

177. Minutes of the Circuit Court of the United States holden at Trenton in and for the New Jersey District, supra note 171; Gazette of the United States and Philadelphia Daily Advertiser (Philadelphia, Pa.), Apr. 11, 1798, at 3, col. 3; The Spectator (New York, N.Y.), Apr. 18, 1798, at 3, col. 2.

178. The occasional frustrations of research in eighteenth century history may be illustrated by the lost account of the Brigstock trial. The State Gazette \& New Jersey Advertiser promised its readers on April 17,1798 , at 3, col. 5, that a full account of the trial was received too late for inclusion, but would be published in pamphlet form. The pamphlet has not survived in the available collections of The State Gazette.

179. Note from Timothy Pickering to Robert Liston (Apr. 13, 1798) (emphasis added), in PICKERING PAPERS, supra note 157, roll 8, at 335; also in DOMESTIC LETTERS OF THE DEPARTMENT OF STATE, 1784 1861, supra note 153. (Pickering again referred to John Evans and Joannes Williams by their Relief pseudonyms, Michael Campbell and Joannes Williamson.)

180. Aurora (Philadelphia, Pa.), Mar. 16, 1798, at 3, col. 2.

181. If Charles Lee was skilled at Cabinet backgammon, he may have wished to push the case to acquittal to enlist the jury as his ally against delivery to the British.

182. Note from Timothy Pickering to Robert Liston (Apr. 13, 1798), supra note 179.

183. Id. (emphasis added). 
ions have been received," deemed the case "not comprehended" within the treaty. Jurisdiction on shipboard was not exclusively British, and treaty article 27 was "conceived to intend" only crimes committed in "the dominion of either [country], in which there is an exclusive jurisdiction" and "in which alone a crime committed can be punished." 184 Crimes such as piracy and murder on the high seas, "on board any vessel whatever" were punishable by the laws of the United States "when the offenders are caught within the same." With a profession of faith in American juries not typical of High Federalists, Pickering instructed Liston that "it is to be presumed, that in all such cases justice will be done." Hence, said Pickering's April 13 note, "For these reasons I am directed by the President of the United States to inform you that William Brigstock cannot be delivered up, and that the other two, Joannes Williamson, a Swede, and Michael Campbell, still confined in New Jersey, will be forthwith discharged." 185

A remarkable circumstance surrounds this April 13 note. Sometime after the note was copied into the State Department Domestic Letterbook, Pickering disclaimed its delivery to Liston; Pickering inscribed in the margin in his own hand, "This letter to Mr. Liston was not delivered to him, the original remains in the office."186 We know that Pickering and Liston were in contact with each other in this period, for on April 18 Pickering wrote to yet another Federal District Judge, John Sloss Hobart of New York, requesting the detention of "seven or eight seamen" lately apprehended in New York, who, "Liston has informed," belonged to the Hermione. ${ }^{187}$ Having avoided placing the United States on record as refusing Brigstock's extradition, Pickering wrote District Attorney Lucius Stockton, on June 8, 1798, to report an exculpatory letter received by Liston from British Vice Admiral Sir Hyde Parker which "expressed his [Parker's] opinion, that from the inquiries he had an opportunity of making, William Brigstock . . was not criminal in the shocking affair of murder and piracy." Pickering asked Stockton to take steps for a discharge. ${ }^{188}$ Without further ado, on June 28, District Attorney Stockton issued a nolle prosequi on Brigstock's charge of murder, "in obedience to the special command of the President of the United States."189

184. Id. (emphasis in original).

185. Id.

186. Note from Timothy Pickering to Robert Liston (Apr. 13, 1798), in DOMESTTC LETTERS OF THE DEPARTMENT OF STATE, 1784-1861, supra note 153. This notation is not made on the letterbook copy of the April 13 note among Pickering's personal papers.

187. Letter from Timothy Pickering to Judge Hobart (Apr. 18, 1798), in DOMESTIC LETTERS OF THE DEPARTMENT OF STATE, 1784-1861, supra note 153.

188. Letter from Timothy Pickering to Lucius Stockton (June 8, 1798), in DOMESTIC LETTERS OF THE DEPARTMENT OF STATE, 1784-1861, supra note 153; also in PICKERING PAPERS, supra note 157, roll 8, at 532. "Is there any way to relieve him before the next session of the circuit court?" asked Pickering. Holding court twice a year had its hazards.

189. Notice of Nolle Prosequi (June 28, 1798), in "Circuit Court of the United States, Middle Circuit of the New-Jersey District. The United States (a.) Will:am Brigstock," supra note 156. It appears Brigstock 
One could read these events straightforwardly; perhaps Brigstock was the beneficiary of conscientious inquiry by Vice Admiral Hyde Parker. ${ }^{190}$ But the events also permit the inference that Pickering was reluctant to place the United States on record as refusing extradition, so that Lee's opinion could be challenged on another occasion. Liston and Pickering were congenial, ${ }^{191}$ and it seems tenable that Pickering would informally have told Liston of Lee's opinion, agreeing on the prudence of disposing of the matter without adopting the Attorney General's opinion as the stated position of the United States government.

The nolle prosequi also permits the inference that Adams or Pickering, or both, regarded impressment as a colorable excuse for rebellion, at least an excuse demanded by the public as sufficient. ${ }^{192}$ This would have been fully consistent with Adams' youthful career. Twenty-nine years before, as a lawyer in Boston, Adams championed the right of self-defense against illegal impressment. In 1769, American seaman Michael Corbet killed Lieutenant Panton of the H.M.S. Rose during an impressment on an American merchant vessel, and John Adams and James Otis were engaged for the defense. ${ }^{193}$ Corbet's killing of Panton was not argued by Adams as a passionate act, seeking manslaughter in place of murder, ${ }^{194}$ but rather as innocent. Impressment lacked express

was not actually discharged from jail until August 1, 1798. See Aurora (Philadelphia, Pa.), Aug. 9, 1798, at 2 , col. 3. The nolle prosequi was formally entered at the next term of the Circuit Court before Justice William Cushing and District Judge Robert Morris in October 1798. Minutes of the Circuit Court of the United States holden at Trenton in and for the New Jersey District, supra note 171.

190. Brigstock had, after all, been transferred to the Hermione with Captain Pigot in February 1797 from H.M.S. Success, along with 21 others; whether this indicates any special regard between Pigot and Brigstock is harder to tell. See HeRmione MUSTER BOOK (FEB. 10-27, 1797) (British Public Record Office, Adm. 36/12011) (entry nos. 615-37).

191. Pickering recognized that critics might make use of any evident connection to Liston. Declining an invitation to dine, Pickering complained that the Congress "do not allow persons holding executive offices ... to have any convivial intercourse with foreign ministers. . . . It is deemed . . . indulgence enough to live on mutton, mush and cold water." Note from Timothy Pickering to Robert Liston (Mar. 13, 1798) (emphasis in original), in PICKERING PAPERS, supra note 157, roll 8, at 204.

192. On May 15, 1799, in a formal note, Pickering would remind Adams of the Brigstock matter, "One only was detained some time longer, on a suggestion or expectation of decisive evidence against him: but it appeared afterwards that this man was not involved in the offense; and at Mr. Liston's request he was discharged." Note from Timothy Pickering to President John Adams (May 15, 1799), in ADAMS PAPERS, LETTERS RECEIVED AND OTHER LOOSE PAPERS, roll 394, at 219-219a (Massachusetts Historical Society microfilm edition). If one concludes this correspondence was written with an eye to possible public scrutiny, the reference to insufficient evidence and Mr. Liston's request may be taken as demure diplomacy. The explanation given to the press for Brigstock's discharge was that the "President ... [had] obtain[ed] from the court of Great Britain satisfactory information of his innocency, of the horrid and detestable crimes alleged against him." Aurora (Philadelphia, $\mathrm{Pa}$ ), Aug. 9, 1798, at 2, col. 5. It is also conceivable that Pickering and Liston saw no need to roil Adams with the problem of Brigstock's impressment or the jurisdictional dispute with Lee, by dismissing on the ground of lack of evidence.

193. See J. Adams, Argument and Report, 2 LEGAL PAPERS OF JOHN ADAMS 285-88, 322-35 (L. Wroth \& H. Zobel eds. 1965); also in 2 THE WORKS OF JOHN ADAMS 526-29 app. (C. Adams ed. 1850) (with slight textual variations).

194. This appears to have been wise lawyering by Adams. The penalty for manslaughter was death, and it was not clear that a defendant in admiralty could escape execution by the privilege of benefit of clergy. 
Parliamentary authorization. Impressment was conducted under Admiralty warrants, an uncertain species of Crown prerogative power and, Adams was prepared to argue, a statute of Anne appeared to forbid all impressments in trade with the Americas. ${ }^{195}$ Color of authority did not require submission; the victim did not have to wait for judicial intervention. Corbet could resist Lieutenant Panton's act of arrest as self-defense:

[I]f Impresses are always illegal, and Lt. Panton acted as an Impress Officer, Michael Corb[et] and his Associates had a Right to resist him, and if they could not otherwise preserve their Liberty, to take away his Life. His Blood must lye at his own Door, and they be held guiltless. ${ }^{196}$

Adams and Otis failed to gain a jury trial for Corbet, but more remarkably won a bench acquittal. ${ }^{197}$ Years later Adams speculated that the admiralty judges had "dared not pronounce judgment in favor of impressment .... Such a judgment would, at that time, have been condemned, reprobated, and execrated ... . It would have accelerated the revolution." ${ }^{198}$ As Minister to Great Brit-

195. Act for the Encouragement of the Trade to America, 6 Anne, ch. $37, \S 9$ (1707). This statute was repealed in 1775. See An Act for the Encouragement of the Fisheries carried on from Great Britain, Ireland, and the British Dominions in Europe, and for securing the Return of the Fishermen, Sailors, and others employed in the said Fisheries, to the Ports thereof, at the End of the Fishing Season, 15 Geo. 3, ch. 31, $\S 19$ (1775).

196. J. Adams, Argument and Report, in 2 LEGAL PAPERS OF JOHN ADAMS, supra note 193, at 322.

197. Other sources for the Corbet trial include Adams' Minutes of the Trial, in 2 LEGAL PAPERS OF JOHN ADAMS, supra note 193, at 293-322; and Adams' diary entry for December 23, 1769, in 2 THE WORKS OF JOHN ADAMS, supra note 193, at 224; also in 1 DIARY AND AUTOBIOGRAPHY OF JOHN ADAMS 347 (L. Butterfield ed. 1961). Popular accounts are available in 1 P. CHANDLER, AMERICAN CRMMNAL TRIALs 295 (1844); 3 T. HUTCHINSON, HISTORY OF MASSACHUSETTS BAY 231-33 \& n. (London 1828); and Boston Evening Post, July 24, 1769, at 1, col. 2. Said former British Governor Hutchinson of Massachusetts, "It appeared that neither the lieutenant nor any of his superior officers were authorized to impress, by any warrant or special authority from the lords of the admiralty; and the court (the commanding officer of the king's ships being one of the commissioners) was unanimously of opinion that the prisoners had a good right to defend themselves, and though the fact of killing was fully proved, that they ought to be acquitted of murder, with which they were charged, and that, at common law, the killing would not have amounted to manslaughter."

198. Letter from John Adams to Judge William Tudor (Dec. 30, 1816), in 2 THE WORKS OF JOHN ADAMS, supra note 193, at 224 n.*. The memorable quality of the trial for Adams was shown in his correspondence with William Tudor, disclosing as well Adams' excitable nature, self-dramatization, and, odd for a man mocked as His Rotundity, his likable self-deprecation:

I cannot say whether I ought to laugh, or cry, or scold, in reporting the trial of Michael Corbet and his three comrades. You must remember it. ... The whole burden of responsibility was ... cast upon me. You may easily believe I was anxious; the lives of four honest men in my hands, and a sympathizing world looking to me for exertions to preserve them. . . . It . . . became my turn to speak in defence of the prisoners. I had taken more pains in that case than in any other, before or since; I had appealed to Heaven and earth; I had investigated all laws, human and divine; I had searched all the authorities in the civil law, the law of nature and nations, the common law, history, practice, and every thing that could have any relation to the subject. All my books were on the table before me, and I vainly felt as if I could shake the town and the world. ... I had scarcely risen and said "May it please your Excellencies and your Honors. My defence of the prisoners, is, that the melancholy action for which they stand accused is justifiable homicide, and therefore no crime at all," and produced one authority very plump to that purpose, -when Hutchinson again darted up, and moved that the Court should adjourn to the council 
ain, following the Revolution, Adams again protested the "practice, which has been all too common, of impressing American citizens, and especially with the aggravating circumstances of going on board American vessels, which ought to be protected by the flag of their sovereign," 199 and informed Secretary of Foreign Affairs John Jay that he was demanding British release of all impressed American sailors. ${ }^{200}$

As a young protestant against British imposition, Adams had involved himself in other affairs of resistance. A remonstrance in 1774 from the Continental Congress to the King complained of the overseas trial of criminal offenses, beyond the absolving power of American jurymen. Witnesses could be hard to obtain at a distance, and the sovereign role of the jury administering the rite of last clear chance, would be lost. Massachusetts delegates who approved the remonstrance included cousins John and Samuel Adams. ${ }^{201}$

chamber! No reason was given; not a word was said .... Dismal was the anxiety of the town, dreading a sentence of death the next morning. Alas, for me, my glass bubble was burst! my boule de savon [ball of soap] was dissolved! all the inflammable gas was escaped from my balloon, and down I dropt like Pilâtre des Rosiers.

The Pilatre des Rosiers dampened his career as a French balloonist by plunging in the English Channel. Counsellor Adams saw a like prospect, not foreseeing victory.

Never was a more gloomy assembly of countenances painted with terror and horror, than appeared in the audience next morning. The Court appeared; the prisoners were ordered to the bar. The President arose, and pronounced the unanimous sentence of the court, -that the killing Lieutenant Panton was justifiable homicide in necessary self-defence. . . [T] [rue history, in this case, is the most surprising romance and the keenest satire. But I have not yet explained the secret. First and last, it was FEAR. . . . They dared not pronounce judgment in favor of impressment in any possible case. . . . Such a judgment would, at that time, have been condemned, reprobated, and execrated, not only in New England and all the other Colonies, but throughout the three kingdoms. It would have accelerated the revolution more than even the impeachment of the judges, or Hutchinson's foolish controversy about the omniscience and omnipotence and infinite goodness of Parliament did afterwards. It would have spread a wider flame than Otis's ever did, or could have done.

Letter from John Adams to Judge William Tudor (Dec. 30, 1816), in 2 THE WORKS OF JOHN ADAMS, supra note 193, at 224 n.* (paragraphing omitted, emphasis in original). Adams thought the colonial judges were protecting a Parliamentary agenda as well: controversy over Corbet could thwart plans to repeal the statute of Anne, see Act for the Encouragement of the Trade to America, 6 Anne, ch. 37, § 9 (1707), which limited impressment from American trading vessels. The statute of Anne was in fact repealed in 1775. See supra note 195 .

199. Letter from Minister to Great Britain John Adams to Lord Carmarthen (Oct. 3, 1787), in 8 THE WORKS OF JOHN ADAMS, supra note 193, at 455-56.

200. Letter from John Adams to John Jay (Sept. 22, 1787), in 8 id. at 450-51.

201. Declaration and Resolves of the First Continental Congress, October 14, 1774, 1 JOURNAL OF THE CONTINENTAL CONGRESS, 1774-1789, at 63, 71-72 (W. Ford ed. 1904); 2 THE WORKS OF JOHN ADAMS, supra note 193, at 535. The short-lived Stamp Act, 5 Geo. 3, ch. 12, §§ 56-57 (1765), and an import revenue statute, 4 Geo. 3, ch. 15, $\& 41$ (1763), allowed the Vice-Admiralty to prosecute American violations in England without a jury. A 1772 dockyards statute made attacks on British naval vessels and military stores triable in England even though committed in North America, 12 Geo. 3, ch. 24, and officials accused of committing felonies while enforcing colonial statutes could avoid the angry vicinage by removal of the trial to England or another colony on the demand of the royal governor and Council. 14 Geo. 3, ch. 45 (1774). John Adams claimed authorship of the Declaration and Resolves' fourth article disputing Parliament's right to legislate for the colonies in matters of "taxation and internal polity." See Autobiography of John Adams, in 2 THE WORKS OF JOHN ADAMS, supra note 193, at 374. 
To be sure, the Adams who arrives stage right in the 1798 Hermione tableau is a bit the worse for wear. He has published A Defence of the Constitutions of Government of the United States of America, examining the problems of corruption in classical and renaissance republics and warning of their repetition in the American scene. It was essential that popular interest should be represented in government. Yet property also must be protected, and for this, said Adams, the legislative power should be divided, with separate legislative chambers, and a strong executive to balance the two orders of men. ${ }^{202}$ The English Constitution was the best form of government, and a lifetime monarch the best form of an executive. ${ }^{203}$ Adams strikes one as an innocent reader of Polybius, who wished to apply-with the ahistorical scientism of the eighteenth century - what seemed the lesson of classical history for maintaining a stable polity. Adams never seems to have realized why his candid expression of belief should lessen his repute; voicing these opinions at large might show respect for the generous understanding of ordinary men, but might also be taken to evidence his own constitutional plans, and at the least, lacked tact. Adams repeated these views in Discourses on Davila in 1790, his commentary on France's religious civil wars of the sixteenth century and their Italian chronicler, Enrico Davila, and, in truth, a commentary on the latest events in France. ${ }^{204}$ This is also the Adams who, in his alarm at the excesses of French revolutionary violence, and fear of its spread under the guise of philosophical radicalism

202. See $3 \mathrm{~J}$. ADAMS, A DEFENCE OF THE CONSTITUTIONS OF GOVERNMENT OF THE UNTED STATES OF AMERICA (1788), in 6 THE WORKS OF JOHN ADAMS, supra note 193, at 68-69:

In every society where property exists, there will ever be a struggle between rich and poor. Mixed in one assembly, equal laws can never be expected. They will either be made by numbers, to plunder the few who are rich, or by influence, to fleece the many who are poor. Both rich and poor, then, must be made independent, that equal justice may be done, and equal liberty enjoyed by all.

A French translation of the Defence was published in Paris in 1792. A second edition was published in London in 1794, and a third edition in Philadelphia by William Cobbett in 1797.

203. See 3 J. ADAMS, A DEFENCE OF THE CONSTTTUTIONS OF GOVERNMENT OF THE UNTTED STATES OF AMERICA (1788), in 6 THE WORKS OF JOHN ADAMS, supra note 193, at 57, 117. Monarchy was "less friendly to the monster" of faction than was "a simple popular government"; only "a mixed government, of three independent orders, of the one, the few, and the many, and three separate powers, the legislative, executive, and judicial" could quell factions over time. Id. at 50 . A hereditary monarchy could be "republican" in Adams' lexicon. "Whenever I use the word republic with approbation, I mean a government in which the people have collectively or by representation, an essential share in the sovereignty." Letter from John Adams to Samuel Adams (Oct. 18, 1790) (emphasis in original), in 6 THE WORKS OF JOHN ADAMS, supra note 193, at 415. The danger in the American Constitution was that, lacking an absolute veto, the Presidency could be overcome by the legislature in "cases . . . such as attack his constitutional power." It is "certain [the President] has not equal power to defend himself, or the constitution, or the judicial power." "The legislative power ... will, therefore, encroach, because both aristocratical and democratical passions are insatiable." Letter from John Adams to Roger Sherman (July 18, 1789), in 6 THE WORKS OF JOHN ADAMS, supra note 193 , at 431.

204. The Discourses on Davila were originally published as pseudonymous essays in the Gazette of the United States in 1790 and 1791, but Adams was quickly identified as the author. In retirement Adams collected and republished the essays as DISCOURSES ON DAVILA (Boston 1805); also in 6 THE WORKS OF JOHN ADAMS, supra note 193, at 221. A 1757 French translation of Davila's Historia delle guerre civili di Francia used in preparing the Discourses survives with Adams' marginalia in the Rare Book Department of the Boston Public Library. 


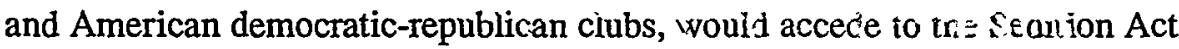
with its invitation to punish disparaging critics, and the Alien Act, with its assignment of authority to expel politically suspect aliens. ${ }^{205}$ In Republican eyes, the summary authority delegated to the President over the literies of aliens was close cousin to the prerogative power of the Crown. Yet, still and all, it seems unlikely that Adams would have lapsed from his earlier fervent condemnation of British impressment. ${ }^{206}$

In all the Cabinet correspondence concerning Brigstock, there is no reference to the Hermione's fame. But the Hermione mutiny and the death of Captain Pigot were already serving for Republican lesson. As Pickering surely understood, juries read newspapers. Ship and master had a past. On July 4, 1795, Philip Freneau's Jersey Chronicle detailed Pigot's early impressments as captain of the frigate Success: in one sweep Pigot had summarily seized twothirds of the American sailors in the port of Jeremie, Santo Domingo. ${ }^{207}$ On the very day of this report, under a different master, the Hermione also visited Jeremie and took Americans en masse. ${ }^{208}$ James Callender, a Republican editor from Scotland, used his History of the United States for 1796 to recirculate these complaints. ${ }^{209}$ Though Secretary of State Pickering protested the impressments, ${ }^{210}$ the public posture of the Federalists, in seeking to avoid a

205. See An Act, in addition to the act, entitled "An act for the punishment of certain crimes against the United States," 1 Stat. 596 (July 14, 1798) (popularly known as the Sedition Act); An Act concerning Aliens, 1 Stat. 570, 571 (June 25, 1798) (popularly known as the Alien Act); J. MILLER, CRISIS IN FREEDOM: THE ALIEN AND SEDITION ACTS (1951); J. SMTTH, FREEDOM'S FETTERS: THE ALIEN AND SEDITION LAWS AND AMERICAN CIVIL LIBERTIES (1956).

206. See, e.g., J. ADAMS, INADMISSIBLE PRINCIPLES OF THE KING's PROClamation (Boston 1809); also in 9 THE WORKS OF JOHN ADAMS, supra note 193, at 312, 330 (1808 embargo was appropriate remedy against British impressment of American seamen; "let them keep their arbitrary powers at home, not practise them upon us, our ships, or seamen").

207. Jersey Chronicle (Mount Pleasant, N.J.), July 4, 1795, at 83, col. 2.

208. Aurora (Philadelphia, Pa), Aug. 8, 1795, at 2, col. 2; New Jersey State Gazette (Trenton, N.J.), Aug. 11, 1795, at 2, col. 4; Jersey Chronicle (Mount Pleasant, N.J.), Aug. 22, 1795, at 145, col. 2.

209. J. CALLENDER, THE HISTORY OF THE UNITED STATES FOR 1796, at 90, 130 (Philadelphia 1797). In March 1796, an American captain arriving from Port-au-Prince allowed that the Hermione had "pressed, from time to time, a vast number of American seamen out of different vessels. On a moderate calculation, two-thirds of [its] crew were Americans." Id. at 130 (emphasis in original).

210. After the Jeremie incident, Pickering instructed the American Minister in London to protest the "cruelty and brutality" of the Hermione captain "who on the 4th of July 1795, . . stripped upwards of twenty American vessels of their crews; impressing all the men, excepting the Captains and Mates." Had Britain "studied to keep up the irritation in the minds of Americans, and wished to prevent the return of our good will, some of her naval commanders appear perfectly qualified for the object."Letter from Timothy Pickering to John Quincy Adams or William Allen Deas (Sept. 12, 1795), in DIPLOMATIC AND CONSULAR INSTRUCTIONS OF THE DEPARTMENT OF STATE, 1791-1801 (National Archives Microfilm Publication M28, roll 3); also in INSTRUCTIONS TO THE BRITISH MINISTERS TO THE UNITED STATES, 1791-1812, supra note 9, at 105 n.11. Pickering acted upon the Jessup incident as well, confidentially instructing the Minister to Great Britain, Rufus King, to make "a solemn remonstrance on the tyrannical and inhuman conduct of Captain Pigot." Pickering continued presciently, "I am only astonished at the quiet submission of Captain Jessup and other American citizens, victims of the frequent tyranny and cruelty of British officers, and that some of them do not take instant vengeance on the ruffians who thus put them to the torture." Letter from Timothy Pickering to Rufus King (Sept. 10, 1796), in 2 LIFE AND CORRESPONDENCE OF RUFUS KING 115-16 (C. King ed. 1895); also in INSTRUCTIONS TO THE BRITISH MINISTERS TO THE UNITED STATES, 1791-1812, supra note 9 , at 122 n.56. 
break with England, left obvious vulnerabilities. How could protests be taken seriously if force was not threatened?

The Philadelphia Aurora, which served as the posterboard for Republican polemics in the national capital, ${ }^{211}$ welcomed the mutinies in the British fleets at Spithead and Nore in April and May 1797, at a time when France and ally Holland were debating invasion of England. ${ }^{212}$ The mutinies were Britain's due pay for impressing American and other neutrals; they proved American virtue would not suffer British tyranny. ${ }^{213}$ With the financial difficulties of England, the sailor rebellions would "go far to relieve the world from the future oppression of the British navy."214 The first Republican reports of the Hermione mutiny offered no praise, ${ }^{215}$ but when Mrs. Martin returned to the

211. On the early history of the Aurora and its first publisher Benjamin Franklin Bache, grandson of the kite-flyer, see J. Tagg, Benjamin Franklin Bache and the Philadelphia Aurora (doctoral thesis, Wayne State Univ., 1973), to be published by Univ. of Pa. Press (1991); B. FAY, THE Two FRANKLINS (1933); ClAUDE-ANNE LOPEZ \& EUGENIA HERBERT, THE PRIVATE FRANKLIN 310-12 (1975); J. SMITH, FRANKLIN \& BACHE: ENVISIONING THE ENLIGHTENED REPUBLIC (1990). Bache catalyzed the public explosion over the Jay Treaty in 1795: proof that leaks are as old as the Republic, the Aurora made public the text of the Jay Treaty before the Senate deigned to release it, see supra page 262.

212. The French Directory had already set in motion an unsuccessful invasion of Ireland in December 1796 and a landing in Wales in February 1797. At the time of England's Channel Fleet mutiny at Spithead in April 1797 and North Sea Fleet mutiny at Nore in May 1797, the Dutch had 42 transports designated for a cross-Channel invasion, a plan interrupted by a two-ship British blockade of the Dutch harbor at Texel. In October 1797 the Directory appointed Napoleon to command an army for invasion of England. Napoleon put aside plans for any immediate invasion only in February 1798 when he reached Dunkirk and found naval preparations were inadequate. In May 1798 Napoleon set out by sail for Malta and Egypt, but the uncertainty about his intention and the slow receipt of news left Federalist observers concerned through the summer of 1798 that Napoleon's Armée d'Angleterre might burst across the Channel. See A LETTER FROM ROBERT GOODLOE HARPER OF SOUTH CAROLINA, TO ONE OF HIS CONSTITUENTS 19 (Philadelphia W. Cobbett publ. Aug. 1798) ("By the latest accounts there appears reason to believe that the invasion of England, so long threatened, is at length given up."), available in EARLY AMERICAN IMPRINT, 1639-1800, supra note 116 (Evans No. 33838). For a brief account of Napoleon's thrusts, see 2 J. FULLER, A MIITARY HISTORY OF THE WESTERN WORLD 370-75 (1955).

213. "It is highly probable that the unjust, slavish and tyrannical practice of impressing not only British citizens, but those of America, Sweden, and other neutrals, has been the cause of the late mutiny in the British navy," offered the Aurora. "The impressed Americans and other neutrals have, no doubt, contributed to shew the British and Irish sailors the cruelty and wickedness of being forced from their country, their homes, their families, and the good and plentiful provisions and high wages in the merchant service." Aurora (Philadelphia, Pa.), June 22, 1797, at 2, col. 3 (emphasis in original).

214. Id. When British marines fired on some of the Channel sailors, Aurora editor Benjamin Franklin Bache supposed that the "hatred . . . encreased by actual violence could complete the destruction of that engine of domestic and foreign tyranny, the British navy." Id., June 26, 1797, at 3, col. 5.

215. The Aurora reprinted the account of the Gazette of the United States, a Federalist paper:

When about 3 days out from Cape Nicola Mole, on a cruise, part of the crew were engaged handing the mizen topsail; the captain speaking sharp to them, two of the men fell from the yards; when the others came down they were reprimanded in harsh terms by the captain, and several of them threatened with punishment-this occasioned much discontent, which continued until the next evening, when the mutiny broke out, by throwing double headed shot \&c. about the ship, and other disorderly behaviour. The first lieutenant went down to enquire what they wanted, and was soon wounded in the arm with a tomahawk; he retired for some time, and when he returned was knocked down with a tomahawk, his throat cut, and thrown overboard-After which the sailors proceeded to the cabin in search of the captain who had locked himself in, but was soon dragged out (after having wounded 2 or 3 in defending himself with his sword) and experienced the fate of his unfortunate lieutenant: they afterwards seized upon and murdered every officer in the ship, except a master's mate, and two midshipmen. 
United States, she gained attention for "assign[ing] as the cause of the mutiny the great severity of Capt. Pigot, who was constantly flogging the men."216 The killing of Captain Pigot gave occasion to discern Federalists' indifference to the hardships of American sailors, "When the American capt. Jessup was flayed alive by PIGOT," complained the Aurora of its editorial opponents, "they could palliate and apologize; but now that Pigot dies by the hands of those over whom he has tyrannized, no terms of execration are strong enough to brand those who have inflicted on him merited punishment."217 Said one Republican correspondent, "They rose upon their officers, killed them, and carried the ship into a Spanish port. For this even we are glad, and John Fenno is sorry. The public are left to decide between us." 218

The Federalist papers responded in kind. Initial coverage of the mutiny was restrained, ${ }^{219}$ and the Brigstock acquittals were covered without comment. ${ }^{220}$ But on July 3, 1798, the Charleston State Gazette and Timothy's Daily Advertiser ran a two column account of the British court-martial of other Hermione mutineers, tried and convicted on the H.M.S. York off Mole Saint Nicholas, Santo Domingo, on March 17, 1798. Timothy's introduced the story to its Charleston readers with a lugubrious moral, noting that these four, and three more besides, had been caught and executed. The "fate of these sanguinary delinquents may prove an example to deter others from the commission of such foul and horrid crimes," hoped the editor. Timothy's gave cautionary instruction to the readership by the court-martial's sentence: "when dead, their bodies be hung in chains upon gibbets on such conspicuous points, or head lands, as the commander in chief shall direct." Wider apprehension of the event might aid detection as well; the "publishing of the sentence may greatly tend to the

They then directed their course for La Guira, where they arrived under Spanish colours, and delivered the ship up to the Spanish government, giving out that they had turned their officers adrift in their jolly boat. The Spaniards have since manned the ship and sent her to sea. Our informant further adds, that the crew of the Hermione were a mixture of several nations. Aurora (Philadelphia, Pa), Nov. 17, 1797, at 3, col. 3 (reprinting Gazette of the United States (Philadelphia, Pa.), Nov. 16, 1797, at 2, col. 5).

216. Aurora (Philadelphia, Pa.), Jan. 22, 1798, at 3, col. 4. Callender's account of the Hermione impressments was recirculated with the first reports of the Brigstock arrests. Id., Mar. 16, 1798, at 3, col. 2. Said the clumsy editorialist,

The Hermione was one of the frigates that did the greatest mischief to American trade by the impressment of American seamen... . When the writer of this article first heard of the extirpation of the officers of this execrable corsair, he felt that intense satisfaction which every man must feel, who wishes for the liberty of American seamen. What business our government have to interfere in apprehending the actors of this most laudable enterprize nobody can guess. . . . These men deserve a gold medal, or a pension rather than imprisonment.

Id., Mar. 16, 1798, at 3, cols. 2-3 (paragraphing omitted).

217. Id., Mar. 21, 1798, at 3, col. 3 . States.

218. Id., Mar. 27, 1798, at 3, col. 3. John Fenno was the editor of the Federalist Gazette of the United

219. See, e.g., Gazette of the United States (Philadelphia, Pa.), Nov. 16, 1797, at 2, col. 5; id., Apr. 11, 1798, at 3, col. 3; The State Gazette \& New Jersey Advertiser (Trenton, N.J.), Nov. 28, 1797, at 3, col. 2.

220. E.g., The Spectator (New York, N.Y.), Apr. 18, 1798, at 3, col. 2. 
discovering anc apprenending [of] several others ... of these atrocious offenders."221

The same story was columned in June 1798 in Porcupine's Gazette in Philadelphia, a Federá'ist paper edited by Englishman William Cobbett. Porcupine's introduction was even spicier than Timothy's. The "horrid crimes," said Porcupine, "strike deeply at the safety of nations and at the security of the commercial worid:- it is devoutly to be wished that the fate of these sanguinary delinquents and the just punishment they have suffered, may prove an example to deter uthers.' 222 Attorney General Lee had disapproved Brigstock's extradition just days before the H.M.S York court-martial proceedings. One may wonder whether the news story of the York originated with Robert Liston, still serving as British minister in Philadelphia, hoping to excite a different result if more niuineers drifted ashore.

No other Hermione mutineers were found in a United States port to test John Adams' mettle in 1798. When a Hermione crew member sailed into Charleston in 1799, Adams' youthful memories and the example of Brigstock would not steer him safely through the course.

\section{JONATHAN ROBBINS AND A CHARLESTON JUDGE}

\section{A. The Capture}

Ten months after the Brigstock acquittals, the sailor Jonathan Robbins lost his liberty due to indiscrete conversation, recalling rebellion within hearing of others, spreading the fame of defiance that other captains might fear. Robbins' ship, Tanner's Delight, arrived in Charleston harbor, South Carolina on February 1,1799 , twenty-three days from Santo Domingo, and remained until February 19 when it sailed for New York. ${ }^{223}$ Tanner's Delight sailor William Portlock of Portsmouth, Virginia apparently did not care for his shipmate Jonathan Robbins, and reported to authorities that on the Christmas past a shipmate "who answered to the name of Nathan Robbins" had been "talking in the harbour of the city of St. Domingo, to some French privateersmen" and admitted in earshot "that he, the said Robbins, was boatswain's mate of his

221. South Carolina State Gazette and Timothy's Daily Advertiser (Charleston, S.C.), July 3, 1798, at 3, cols. 1-2.

222. Porcupine's Gazette (Philadelphia. Pa.), June 8, 1798, at 2, col. 3. The English Admiralty' had importuned the Spanish "how essential it was to their own honour, and to the cause of justice and humanity, to deliver ... the atrocious crew of the Hermione," reported The Spectator (New York, N.Y.), Apr. 21, 1798 , at 1 , col. 4 . The A dmiralty "described the delinquencies that would probably result from a different coraucr it. warts all nations might equally suffer."

A Brusu ol oaasid:, heralding the March 17, 1798 convictions in decorative type, is preserved in "INLeTters," ADMIRAL's Disfatches, Jamaica (British Public Record Office Adm. 1/249).

223. See The City Gazette and Daily Advertiser (Charleston, S.C.), Feb. 2, 1799, at 3, col. I; id., Feb. 19, 1799, at 3, col. 1; South Carolina State Gazette and Timothy's Daily Advertiser (Charleston, S.C.), Feb. 2, 1799, at 3, col. 1; id., Feb. 19, 1799, at 3, col. 1. 
Britannic Majesty's frigate Hermione, when she was carried into the port Cavillia." The French privateersmen "had no occasion to take any notice," but Portlock did. In testimony that would be of questionable weight under modern rules of evidence, Portlock swore further that "sometimes when he was drunk, he, the said Robbins, would mention the name of the Hermione, and say, bad luck to her and clench his fist."224

On this recitation of mere presence and ungallant wish, Robbins was committed to jail in South Carolina. It is not clear, from surviving court records, whether the first warrant for his committal was based upon possible violation of United States laws against piracy and murder, or upon the request of Mr. Moodie, the British consul in Charleston, for possible extradition; ${ }^{225}$ John Marshall would later say it was for extradition. ${ }^{226}$ In any event, two months later, on April 18, 1799, shipmate Portlock's statement was supplemented by the affidavit of John Forbes, a British Navy Lieutenant sent from the West Indies, who swore on "the Holy Evangelists of Almighty God" that he knew Robbins as Thomas Nash for a seven-month period on the Hermione before the mutiny. Forbes, who had been Master's Mate, ${ }^{227}$ transferred from the ship before the uprising, but visited the Hermione on September 19, 1797, three days before the up-ending, and saw Nash/Robbins there. Forbes swore that "Thomas Nash was one of the principals in the commission of the . . . acts of murder and piracy"-but Forbes knew Robbins' immediate actions in the fracas only by reviewing "depositions made and testimony given in courtsmartial where some of the said crew have been tried."22s Forbes' written affidavit said nothing more of Robbins' part in the mutiny, clearly failing our modern standards of specificity for a showing of probable cause.

\section{B. The Executive's "Advice and Request"}

No indictment of Robbins for murder or piracy on the high seas was sought at the May 1799 term of the South Carolina Federal Circuit Court, so far as the Circuit Court Minute Book reflects. ${ }^{229}$ Instead, the decision seems to have

224. The Portlock affidavit was reproduced in contemporaneous newspaper accounts, e.g., Carolina Gazette (Charleston, S.C.), Aug. 1, 1799, at 2, col. 1. See also United States v. Rob[b]ins, 27 F. Cas. 825, 826 (D.C.S.C. 1799) (No. 16,175).

225. There is no entry concerning Robbins' arrest in federal court minute books. See MINUTES, CIRCUTT AND DISTRICT COURTS, DISTRICT OF SOUTH CAROLINA, 1789-1849 (National Archives Microfilm Publication M1181, roll 1).

226. 10 ANNALS OF CONG., 6th Cong., 1st Sess. 615 (Mar. 7, 1800).

227. See HERMIONE MUSTER BOOX (FEB. 10-27, 1797) (British Public Record Office, Adm. 36/12011) (entry no. 616).

228. The Forbes affidavit was also reproduced contemporaneously, e.g., Carolina Gazette (Charleston, S.C.), Aug. 1, 1799, at 2, col. 1. See also United States v. Rob[b]ins, 27 F. Cas. at 826.

229. See MINUTES, CIRCUIT AND DISTRICT COURTS, DISTRICT OF SOUTH CAROLINA, 1789-1849, supra note 225. The spring term was held in Charleston from May 7 to May 15. See City Gazette and Daily Advertiser (Charleston, S.C.), May 15, 1799, at 3, col. 2. For Chief Justice Ellsworth's charge to the grand jury, see 3 THE DOCUMENTARY HISTORY OF THE SUPREME COURT OF THE UNTTED STATES, 1789-1800, 
been taken early or instantly to pursue Robbins' delivery to the British. Thus, the Robbins case reopened the question of the scope of the Jay Treaty, and the relation of the treaty power to the House of Representatives. In the aftermath of the Jay Treaty fight, with no implementing legislation for Article 27, the President was left with the treaty obligation, a supremacy clause that made it the law of the land, but no legislated jurisdiction for federal courts to hear extradition matters. The question of who should make decisions in extradition cases remained a subject Republicans could embrace in asserting a popular voice in foreign affairs. If the President and Senate could use the device of a self-executing treaty, the House's wished-for check on foreign undertakings was weakened. Self-execution of a treaty might be a simpler notion if a court were merely selecting rules of decision for a case already before it. But here, selfexecution meant something quite different, namely, that a President or consul had power to obtain arrest, and judges had authority to hear a case and commit to jail, based upon treaty rather than statute.

In May 1799, the British minister Mr. Liston approached Secretary of State Pickering. The South Carolina federal district judge handling the Robbins matter did not believe he could order foreign delivery of the mutineer under the Jay Treaty unless there had been a prior approval by the President. ${ }^{230}$ Later in the nineteenth century, a number of Justices would agree with Charleston Federal District Judge Thomas Bee that the Executive has to give approval of an extradition request in the first instance..$^{231}$

Secretary Pickering wrote President Adams on May 15, 1799, advising the opposite course from the Brigstock affair. Pickering reminded Adams of the Brigstock trial and the acquittal. On "further consideration," advised Pickering smoothly, the treaty article for delivery of criminal fugitives should be read to include offenses committed on shipboard because "the full evidence" for trial would not be available in the United States. ${ }^{232}$ Pickering advised that the

at 357-59 (Maeva Marcus ed. 1990).

230. See Letter from Timothy Pickering to John Adams (May 15, 1799), in ADAMS PAPERS, LETTERS RECEIVED AND OTHER LOOSE PAPERS, supra note 192, roll 394, at 219-219a:

Mr. Liston informs me, that on information rec'd by Admiral Sir Hyde Parker, of one of the mutineers and murderers of the officers of the British frigate Hermione being at Charleston So. Carolina, the Admiral sent thither a vessel on purpose to receive and carry the culprit to the fleet to be tried: but that the district judge had not deemed it proper to deliver him up.

See also Note of Robert Liston to Timothy Pickering (May 23, 1799), in NOTES FROM THE BRTISH LEGATIONS IN THE UNITED STATES TO THE DEPARTMENT OF STATE, 1791-1906, supra note 148:

[O]n the application of the Consul for the restoration of Nash, in conformity to the Treaty of 1794, Judge Bee and the Federal Attorney were of opinion that he could not with propriety be delivered up without a previous requisition on my part made to the Executive Government of the United States.

231. See In re Kaine, 55 U.S. (14 How.) 103, 137 (1852) (Nelson J., Taney, C.J., \& Daniel, J., dissenting); Ex parte Kaine, 14 F. Cas. 78, 82 (C.C.S.D.N.Y. 1853) (No. 7,597).

232. Letter from Timothy Pickering to John Adams (May 15, 1799), supra note 230. Unlike Lee, Pickering read the treaty article as covering maritime jurisdiction as well as dry land. The confusion that surrounded maritime jurisdiction and crimes under the law of nations is evident in the contradiction between Pickering's letter and John Marshall's later opinion. Pickering argues that Robbins' crimes included piracy 
South Carolina federal judge "should be directed to deliver up the offender in question, on the demand of the British Government by its Minister."233 Though Charles Lee was still Attorney General, Pickering gives no sign of consulting Lee on this second round of the Hermione's men. Pickering's advice to Adams on Jonathan Robbins was casuistically reconcilable with the Brigstock events-an offense might be triable within the United States and yet amenable to extradition ${ }^{234}$-but not with Lee's prior opinion on the limits of the treaty. ${ }^{235}$

John Adams replied from Quincy, Massachusetts, within a day of receiving Pickering's advice. ${ }^{236}$ Adams did not resist the re-interpretation of the treaty, but scrupled about the relationship of the judge to the Executive. He surely did not realize the political disaster about to unfold:

under the law of nations, so that any nation could try him, and all the better the country "to which [he] belong[ed]." Yet Marshall would later defend the delivery to the British on the ground that the crime could never be tried in the United States, because it did not constitute piracy under the law of nations. Pickering wrote to Adams,

This question has occurred before, respecting the crew of the Hermione, in consequence of some of them being apprehended in New Jersey, where they were tried and acquitted. One only was detained some time longer, on a suggestion or expectation of decisive evidence against him: but it appeared afterwards that this man was not involved in the offence; and at Mr. Liston's request he was discharged.

The only legal question was, Whether an offense committed on board a public ship of war, on the high seas, was "committed within the jurisdiction" of the party demanding the offender, on a just construction of the 27th article of the treaty. Upon a further consideration of the subject, I am inclined to answer in the affirmative. I suppose the offence committed on board the Hermione to have been a most atrocious act of piracy accompanied with murder: that all nations having jurisdiction in this case, if the pirates be found with their dominions, any of them may try \& punish them: but wanting the full evidence for that purpose, it would seem reasonable, and essential to the due administration of justice, that the culprits be delivered up to the government of the country to which they belong; all nations being interested in the punishment of such pests to society. - On the point abovementioned about the "jurisdiction," it may be observed, that besides the general, concurrent jurisdiction held by Great Britain on the high-seas, her officers have and exercise a particular jurisdiction on board of their own ships. - For these reasons, and as the 27 th article of the treaty especially requires the delivering up of murderers, I respectfully submit my opinion, that the Judge of the District of South Carolina should be directed to deliver up the offender in question, on the demand of the British Government, by its Minister.

Id. (emphasis in original).

233. The same peremptory wording - that a President might "direct" a judge-was used by Pickering in his own earlier note to Judge Morris concerning William Brigstock. See supra page 275.

234. The trial of the Brigstock defendants for piracy under American law would have required the United States to defer any British request for extradition, even were extradition legally permissible. Once an American jury acquitted on the evidence, it would require a ministerial mind to pursue extradition under the treaty.

235. Lee's exclusion from the Robbins decision is also suggested by Lee's later jibes at Pickering. See Letter from James Wilkinson to Alexander Hamilton (Nov. 21, 1799), in 24 THE PAPERS OF ALEXANDER HAMILTON, supra note 78, at 64 ("I think you Should be in Philadela. at an early day, your influence \& your conciliation may I fear become necessary to prevent a dangerous Schism in the ad- $-n$. the Atty. Genl. [Charles Lee] is vociferous in his reprobations of the surrender of Robbins, \& it is whispered that the M. of S. has transcended in that [Robbins] case the presidential authorization.").

236. Letter from John Adams to Timothy Pickering (May 21, 1799), in ADAMS PAPERS, LETTERBOOK, supra note 192, roll 119. We know when Pickering's letter arrived in Quincy by the endorsement made on the foot of the May 15 letter. 
Your favor of 15 th is received. I have no doubt that an offence, committed on board a public ship of war, on the high seas, is committed within the jurisdiction of the nation, to whom the ship belongs. How far the president of the US. would be justifiable in directing the judge, to deliver up the offender, is not clear. I have no objection to advize and request him to do it. ${ }^{237}$

This was Adams' full partake in the Robbins affair until after Robbins was dead. John Adams' handling of the British request hardly seeds the hailstorm of abuse he was to endure. Pickering and Adams can be chastised for varying their interpretations of the Jay Treaty, or for giving the appearance of seeking to evade the absolving power of the jury, or for failing to inquire precautiously whether Robbins might perhaps be American. But the accusation that Adams would have to endure over decades of vilification, is that, instead, he knowingly spurned the plea for help of an impressed American sailor ${ }^{238}$ and interfered with the jurisdiction of the South Carolina federal court in deciding on the evidence and determining questions of law. So far as the record shows, Adams was privy to no claim that Robbins was an American. He was surprisingly delicate concerning the Executive's relation to a judge.

Adams' caution that there might not be power to direct the judge was hardly surprising. It was not clear in what capacity the judge acted. If the judge sat in Article III jurisdiction, it might taint judicial independence to "direct" how he should interpret a treaty, though one could hope for deference to a reasonable executive interpretation. The Judiciary Act, as amended since 1789 , still did not address extradition. A district judge sitting alone had power to bind-over for trial in the federal district or circuit court, but the language of section 33 of the Judiciary Act gave doubtful warrant for binding-over in extradition. ${ }^{239}$ Under the 1789 Act, a lower federal court lacked federal question jurisdiction; it was not enough for a case to "arise" under a treaty, unless one accepted a

237. Id. (emphasis added).

238. The mischaracterization of Adams' action would pass from Republican polemics into standard histories. See, e.g., A. DECONDE, THE QUASI-WAR: THE POLITICS AND DIPLOMACY OF THE UNDECLARED WAR WITH FRANCE 1797-1801, at 205 (1966) ("At the request of Robert Liston, Adams himself looked into the case. The evidence convinced him that Nash was not in fact an American citizen. So the President directed the federal authorities in South Carolina to turn him over to the Royal Navy."); 2 A. BEVERIDGE, THE LIFE OF JOHN MARSHALL 458-59 (1916) ("On overwhelming evidence, uncontradicted except by Nash, that the accused man was a British subject and a murderer, President Adams requested Judge Bee . . . to deliver Nash to the British Consul.").

239. See supra note 55. Jurisdiction to consider a writ of habeas corpus, see Ex parte Bollman, 8 U.S. (4 Cranch) 75 (1807), could not solve Judge Bee's jurisdictional quandary, for he had to discern by what lights he could detain Jonathan Robbins in the first place. As Ex parte Bollman aptly notes, "the decision that the individual shall be imprisoned must always precede the application for a writ of habeas corpus ... " 8 U.S. (4 Cranch) at 101.

If Judge Bee concluded that the United States had concurrent jurisdiction to prosecute the crime of murder at sea, Robbins' binding-over could be rationalized as serving the purpose of domestic prosecution. But then process should have been returned to the clerk of the Circuit Court, see 1789 Judiciary Act, $\$ 33$, 1 Stat. at 91 . The failure to seek Robbins' indictment at the spring term of the United States Circuit Court makes the argument additionally awkward. 
self-executing Article III. If the federal court had no jurisdiction, a President's choice would be to seek a warrant of arrest from a state court, or to act upon a purely "executive" warrant of arrest, or to enlist the assistance of a federal judge acting in an extra-judicial (or at least extra-Article III) capacity, or to leave the treaty unexecuted.

Conceivably a federal judge could sit in a non-Article III capacity as a treaty commissioner. Hayburn's Case ${ }^{240}$ was within recent memory. Chief Justice John Jay and Justice William Cushing had determined that they could not sit as a Circuit Court to determine the merits of pensions for disabled veterans of the Revolutionary War, because the decisions were subject to review by the Secretary of War and would be funded only if Congress agreed. Yet Jay and Cushing agreed to perform the same duties as commissioners sitting out of doors, in that part-time conception of judicial office persisting so late into the nineteenth century. ${ }^{241}$ All the Justices declined President Washington's urgent request for advice in 1793 concerning the law of nations and the duties of neutrals, when Citizen Genêt sought permission to outfit French privateers in American ports, yet Supreme Court Justices continued to undertake diplomatic and international duties. Chief Justice Jay missed an entire Term of Court on his mission to England in 1794, as would Chief Justice Oliver Ellsworth in 1799 in treating with the French. John Marshall also lived a brief double life. After his service in the 1800 Congress and a short stint as Secretary of War, he was appointed Secretary of State by Adams. The Chief Justiceship followed in February 1801, yet Marshall did not resign as Secretary of State until the conclusion of Adams' term in March 1801. A judge could be chosen for his discretion, yet charged to act out of judicial office.

240. 2 U.S. (2 Dall.) 409 (1792).

241. Justices James Wilson and John Blair took the stricter view that they would not sit in any capacity, refusing to hear the pension petition of Hayburn on circuit in Pennsylvania. 2 U.S. (2 Dall.) at 409 . Chief Justice Jay and Justice Cushing tried to save the constitutionality of the pension act's assignment by reading the statute as "appointing commissioners . . . by official instead of personal description" -appointing, to a new statutory office, men who happened to be Circuit Court judges. See 2 U.S. (2 Dall.) at 410 n. This was a somewhat wishful construction, since the pension statute spoke of "powers given by this act to the respective circuit courts." See An Act to provide for the settlement of the Claims of Widows and Orphans barred by the limitations heretofore established, and to regulate the Claims to Invalid Pensions, $\S 3,1$ Stat. 243, 244 (Mar. 23, 1792). Justice James Iredell initially demurred but then accepted his ersatz appointment as a pension act commissioner. "We have had a great deal of business to do here," he wrote his wife from a circuit stop at Hartford, "particularly as I have reconciled myself to the propriety of doing the Invalidbusiness out of Court." See Letter of James Iredell to Hannah Iredell (Sept. 30, 1792), in 2 THE DOCUMENTARY HISTORY OF THE SUPREME COURT OF THE UNITED STATES, 1789-1800: THE JUSTICES ON CIRCUT, 1790-1794, supra note 37 , at 301.

After Justices Wilson and Blair scrupled at the assignment of administrative duties to the Circuit Courts, Congress amended the Invalid Pensions Act on February 28, 1793, 1 Stat. at 324. But even the amended statute called for the federal district court judge to play an administrative role as a protonotary: Section 1 directed that "All evidence relative to Invalids" was to "be taken upon oath or affirmation before the judge of the district, in which such invalids reside" or before any three persons "specially authorized by commission from the said judge." Section 2 instructed "That the judge of the district shall transmit a list of such claims, accompanied by the evidence" to the Secretary of War, who in turn would put the cases to Congress for action. 
But subject matter made the assignment awkward. It would be one thing to act as an administrative law judge or treaty commissioner in determining a monetary award. It was another to deprive a person of freedom-arresting and detaining almost as a species of prerogative councillor, uncomfortably close to the Privy Council actions challenged in England's seventeenth century settlement, to Republicans an unimaginable exemplar. ${ }^{242}$ A federal district judge had charge of the Great Writ, the jurisdiction to review any executive act of detention, in habeas corpus. ${ }^{243}$ What was the propriety of acting himself as a treaty commissioner subject to his own review? ? $^{244}$

Private rehearsal was followed by formal diplomatic correspondence. Minister Liston, though in Philadelphia, wrote to Pickering on May 23, 1799, calling Robbins by the name recorded for him in British navy records, Thomas Nash, asking Pickering to "lay this matter before the President, and procure his orders that the said Thomas Nash be delivered up to justice."245

On June 3, 1799, Pickering prepared an advice to Judge Bee whose wording brought on the political excitement. Pickering informed Judge Bee that the "President has ... a authorized me to communicate to you 'his advice and request,' that Thomas Nash may be delivered up," "[p]rovided such evidence of his criminality be produced, as by the laws of the United States, or of South Carolina, would justify his apprehension and commitment for trial."246 A

242. Even in England, by the mid-eighteenth century, prerogative powers were in retreat. Lord Camden's famous decision in Entick v. Carrington, 95 Eng. Rep. 807 (Common Pleas 1765); also in 19 STATE TRIALS 1029 (T. Howeil ed. London 1814), denied the authority of an individual privy councillor to issue a warrant of arrest in any case other than high treason. 1789).

243. An Act to establish the Judicial Courts of the United States, $\$ 14,1$ Stat. 73, $81-82$ (Sept. 24,

244. The appointments clause of Article II posed another, less profound, difficulty. Only "Congress" acting "by Law" can vest the appointment of "inferior Officers" in the President alone; otherwise "Officers of the United States" require Senate confirmation. U.S. CoNST. art. II, § 2, cl. 2. Would one-time confirmation of a federal district judge mean the President could forever assign him collateral duties, avoiding separate confirmation for the treaty office?

245. Note from Robert Liston to Timothy Pickering (May 23, 1799), in NOTES FROM THE BRTISH LEGATIONS IN THE UNTTED STATES TO THE DEPARTMENT OF STATE, 1791-1906, supra note 148, at 108:

A seaman of the name of Thomas Nash having been committed to Gaol in Charleston (South

Carolina) at the instance of His Majesty's Consul there, on suspicion of his having been an accomplice in the piracy and murder committed on board His Majesty's ship Hermione, and information of the circumstance having been transmitted to Vice Admiral Sir Hyde Parker, a Cutter was dispatched to Charleston with an officer on board to whom the man was well known, in order that his person might be identified, and that he should be carried to the West Indies for trial. But, on the application of the Consul for the restoration of Nash, in conformity to the Treaty of 1794, Judge Bee and the Federal Attorney were of the opinion that he could not with propriety be delivered up without a previous requisition on my part made to the Executive Government of the United States. May I therefore request, Sir, that you will be pleased to lay this matter before the President, and procure his orders that the said Thomas Nash be delivered up to justice.

246. Letter from Timothy Pickering to "The Hon. Thomas Bee Esq., Judge of the District of SouthCarolina" (June 3, 1799), in PICKERING PAPERS, supra note 157, roll 11, at 209. The full text follows:

Mr. Liston, the minister of His Britannic Majesty, has requested that Thomas Nash, who was a seaman on board the British frigate Hermione, and who he is informed is now a prisoner in the jail of Charleston, should be delivered up. I have stated the matter to the President of the United States. He considers an offense committed on board a public ship of war, on the high seas, to 
modern pleading filed by the Attorney General "requesting" the rendition of a fugitive would not occasion comment, nor would an affidavit advising the court of the Department of State's interpretation of a treaty. It may be, though, that the federal judge's own uncertainty of the capacity in which he acted increased the danger that Presidential application would be misconstrued as a direct order. ${ }^{247}$

Despite his own revolutionary youth, Judge Thomas $B e e^{248}$ might have been a more appropriate target than Adams for later Republican ire, for Bee's characterization of the strength of the "evidence of ... criminality" presented by the Portlock and Forbes affidavits was to be wishful in the

have been committed within the jurisdiction of the nation to whom the ship belongs. Nash is charged, it is understood, with piracy \& murder committed by him on board the above mentioned British frigate, on the high seas, and consequently "within the jurisdiction" of His Britannic Majesty; and therefore, by the 27th article of the Treaty of Amity with Great Britain, Nash ought to be delivered up, as requested by the British Minister: Provided such evidence of his criminality be produced, as by the laws of the United States, or of South Carolina, would justify his apprehension and commitment for trial, if the offence had been committed within the jurisdiction of the United States. The President has in consequence hereof authorized me to communicate to you "his advice and request," that Thomas Nash may be delivered up to the Consul or other agent of Great Britain, who shall appear to receive him.

Id. (emphasis in original) (noted as "Copied from the Records in the Department of State"); also in 4 STATE PAPERS AND PUBLICK DOCUMENTS OF THE UNITED STATES [WATTE'S AMERICAN STATE PAPERS] 304 (2d ed. Boston 1817) (with slight textual variation). Pickering's confirming letter to Minister Liston used the same language of deference: his letter to Bee was deemed "a request to deliver up" Nash. See Letter from Timothy Pickering to Robert Liston (June 4, 1799), in DOMESTIC LETTERS OF THE DEPARTMENT OF STATE, 1784-1861, supra note 153 .

247. Oddly, John Marshall is part of the reason for historians' unkind interpretation of what Adams had ventured. As we will see, infra page 351, Marshall claimed far stronger power for the Presidency than Adams exercised in this correspondence.

248. Bee was a South Carolina delegate to the Continental Congress. Before the Revolution, he served in the South Carolina General Assembly and actively engaged in the Assembly's quarrels with the Royal Chief Justice. Chief Justice Charles Shinner thought Bee a "furious Liberty Boy[ ]" who "bore [him] much ill will because of his actions during the Stamp Act crisis." Letter from South Carolina Royal Governor Lord Charles Greville Montagu to British Board of Trade (Aug. 6, 1766) (reporting suspension of Chief Justice Shinner), quoted in Robert E. Rector, Thomas Bee and the Revolution in South Carolina, 1760-1790, at 22 (unpublished master's thesis, University of South Carolina, 1971).

General material on Bee, who has never had a full scale biography, may be found in 2 BIOGRAPHICAL DIRECTORY OF THE SOUTH CAROLINA HOUSE OF REPRESENTATIVES, THE COMMONS HOUSE OF ASSEMBLY 1692-1775, at 69-72 (W. Edgar \& N. Louise Bailey eds. 1977), and 2 THE DOCUMENTARY HISTORY OF THE SUPREME COURT OF THE UNITED STATES, 1789-1800, supra note 37, at 102-03. Bee's career in the Continental Congress may be traced in the JOURNALS OF THE CONTINENTAL CONGRESS 1774-1789 (J. Fitzpatricked. 1904-37). See generally E. MCCRADY, SOUTH CAROLINA UNDER THE ROYAL GOVERNMENT, 1775-1780 (1899); W. SMITH, SOUTH CAROLINA AS A ROYAL PROVINCE, 1719-1776 (1903); J. NADELHAFT, THE DiSORDERS OF WAR: THE REVOLUTION IN SOUTH CAROLINA 29 (1981); H. CANADY, GENTLEMEN OF THE BAR: LAWYERS IN COLONIAL SOUTH CAROLINA (1987); Jervey, Marriage and Death Notices from the City Gazette and Daily Advertiser, 37 S.C. HIST. AND GENEAL. MAG. 84, 87-88 (M. Webber ed. 1936); 4 THE DEBATES IN THE SEVERAL STATE CONVENTIONS ON THE ADOPTION OF THE FEDERAL CONSTITUTION, supra note 61, at 253, 317 (Bee chairing South Carolina House of Representatives in debate on federal Constitution); Letter from Nathaniel Pendleton to James Iredell (Mar. 5, 1791), in 1 THE DocUMENTARY HISTORY OF THE SUPREME COURT OF THE UNTTED STATES, 1789-1800: COMMENTARIES ON APPOINTMENTS AND Proceednsgs 719-20 (Maeva Marcus \& James Perry eds. 1985) (mentioning Bee as candidate to replace Rutledge on the Supreme Court); Letter from Alexander Hamilton to George Washington (Nov. 5, 1795), in 19 ThE PAPERS OF ALEXANDER HAMILTON, supra note 78, at 395, 397 (dismissing Bee as candidate for Secretary of State; "I do not know Judge Bee. I have barely thought of him."). 
extreme. The dangers of anachronism invite caution; in measuring Bee as a judge, one must compare his action to eighteenth century practice in bindingover for trial, rather than to the factual demands of late twentieth century criminal procedure. ${ }^{249} \mathrm{But}$ the comparison is still unflattering: Lee, Pickering and Adams evidenced far more caution in the Simon Marcus and Brigstock matters than Bee was to show.

On July 1, 1799, Judge Bee replied to the Secretary of State that Nash was available to the British Consul for rendition. ${ }^{250}$ Judge Bee told the Secretary of State:

In compliance with the request of the president of the United States, as stated in your favour of the $3 \mathrm{~d}$ ult. I gave notice to the British Consul that at the sitting of the district court on this day I should order Thomas Nash, the prisoner charged with having committed murder and piracy on board the British frigate Hermione, on such strong evidence of his criminality as justified his apprehension and commitment for trial, to be brought before me on habeas corpus, in order to his being delivered over agreeable to the 27th article of the treaty of amity with GreatBritain. ${ }^{251}$

Bee noted in completion of his reply:

The Consul attended in court, and requested that the prisoner should remain in jail until he had a convenient opportunity of sending him away. I have therefore directed that he remain in prison until the Consul shall find it convenient to remove him. ${ }^{252}$

The Consul's delay was his undoing. The case of United States v. Nathan Robbins alias Nash was called on July 23, 1799. William Johnson-apparently the same William Johnson who was Speaker of the South Carolina House of Representatives, an ally of Republican Charles Pinckney, and later appointed to the United States Supreme Court by Jefferson ${ }^{253}$-appeared and told Judge

249. $C f$. Letter of Charles Lee to Secretary of State Timothy Pickering (July 28, 1797), in LETTERS FROM AND OPINIONS OF THE ATTORNEYS GENERAL, 1791-1811, supra note 158 (in arrest of William Blount for intriguing with British, Charles Lee advised that the warrant issued by Judge Peters in Pennsylvania could not be executed in Virginia, but the warrant "will be evidence that the proper affidavits have been made before him for arresting William Blount and of itself would be sufficient evidence to a justice of the peace in Virginia to issue a new warrant ....") (emphasis added).

250. Letter from Thomas Bee to Timothy Pickering (July I, 1799). The original letter does not survive in the Miscellaneous Letters of the Department of State or in the Pickering Papers. The letter was among the documents provided to the House of Representatives by President Adams on February 7, 1800, and was widely reprinted at that time. See, e.g., Aurora (Philadelphia, Pa.), Feb. 11, 1800, at 2, col. 3; Virginia Argus (Richmond, Va.), Feb. 25, 1800, at 3, col. 3. 250.

251. Letter from Thomas Bee to Timothy Pickering (July 1, 1799) (emphasis in original), supra note

252. Id.

253. See D. MORGAN, JUSTICE WILLIAM JOHNSON, THE FIRST DISSENTER 29, $31-36$ (1954); J. Hamilton, William Johnson, in 10 DICTIONARY OF AMERICAN BIOGRAPHY 128-29 (D. Malone ed. 1933). Johnson joined South Carolina Republicans in denouncing the Jay Treaty as "highly injurious to the general 
Bee he was "only a few minutes engaged as Council with the Prisoner" and asked for a one day adjournment "to examine into the nature of his case."254 Judge Bee adjourned for two days until Thursday, July $25 .{ }^{255}$ On July 25, boatswain's mate Jonathan Robbins complicated the proceeding - and the fate of the Adams administration-by raising for the first time before the court the question of his nationality and his possible impressment. In an affidavit sworn in open court, Robbins stated that he had been an unwilling member of the Hermione crew, forced into service by a press gang, and was American. A "native of the State of Connecticut, and born in Danbury in that State," "about two years ago" he had been "pressed from on board the brig Betsey of New York, . . . by the crew of the British frigate Hermione, commanded by Captain Wilkinson." He was "detained there, contrary to his will, in the service of the British nation, until the said vessel was captured by those of her crew, who took her into a Spanish port by force." Robbins produced a certificate dated May 1795 from Notary John Keese of New York City; one Jonathan Robbins had sworn before Keese that he was "about twenty-three years" old, "a citizen of the United States of America, and a native of the State of Connecticut," and was "liable to be called in the service of his country."256 But, of course, the document did not establish that the 1795 affiant was the man in the South Carolina jail, and even then was only a prior consistent statement, since the notary did not attest that any corroboration was shown to him.

William Johnson did not appear again as counsel. Robbins was represented at the July 25 argument by Samuel Ker and Colonel Alexander Moultrie, who, together with Judge Bee, may share in the blame for what miscarried. Ker and Moultrie would plead good Republican law and patriotic rhetoric, but failed to develop factually why one should credit Robbins' late-in-the-day claim of citizenship.

Ker argued first. The mutiny was a political offence lacking the mens rea (or animus furandi, as preferred in the eighteenth century) necessary for murder. As Robbins was impressed, said Ker, he "was warranted by the most sacred rights of nature, and the laws of nations, to have recourse to violence in the recovery of that liberty, of which he had been unjustly and unlawfully deprived." ${ }^{257}$ Ker enlisted the authority of eighteenth century international lawyer and Swiss diplomat Emmerich de Vattel, whose mid-century Law of Nations was widely read, arguing a natural right of self-defense. Since Robbins was American, the United States had jurisdiction to try any of his alleged

interests of the United States." See The City Gazette and Daily Advertiser (Charleston, S.C.), Dec. 21, 1795, at 3, col. 1 (resolution of the South Carolina House).

254. MINUTES, CIRCUIT AND DISTRICT COURTS, DISTRICT OF SOUTH CAROLINA, 1789-1849, supra note 225 .

255. Id.

256. United States v. Roblb]ins, 27 F. Cas. at 827.

257. Counsel's arguments were widely reproduced in Republican and Federalist newspapers, and are available in United States v. Rob[b]ins, 27 F. Cas. at 827-31. 
crimes occurring on the high seas, under the law of nations and under the treaty. Building on Republican sentiment opposed to any limits on trial by jury, Ker pressed that a jury was essential to a fair hearing of the claim for a right to rebellion. "These were facts proper to be submitted to a jury of this country, they would well know how to appreciate a defense of this nature if it were necessary to make it." This was a conception of the jury not as repository of local facts about the crime and witnesses, but as last-check organ of political sovereignty. In contradistinction to the view that crimes should be tried where committed, ${ }^{258} \mathrm{Ker}$ argued that the Constitution secured every citizen a right to trial by a jury imbued with domestic political principles, and extradition should not be used as a way of weakening that protection. The Constitution's domestic rule mandating trial at the site of a crime ${ }^{259}$ applied only to crimes within a republican polity; it should not allow an American to be stripped of his New World venire. The authority to set venue for crimes at sea belonged to the Congress for just this reason: to safeguard the slant in favor of liberty. Treaties should not receive a construction "hostile to the sound principles of the constitution, and derogatory to the rights of citizens." Ker made no mention of the Brigstock prosecution or acquittals. But Ker's complaint went to the heart of the Republican brief against the Adams administration, that Federalists seemed to favor Executive power at the expense of popular control.

Robbins' other lawyer was Colonel Alexander Moultrie, trained in England, a former Attorney General of South Carolina, and brother of Governor William Moultrie. Alexander served as a member of the 1776 South Carolina General Assembly, fought in the revolutionary militia until his capture and parole by Cornwallis, and was colleague with Bee on an Assembly committee that proposed mildly democratic changes in the state constitution. Colonel Moultrie had become an ardent or ambitious Republican, leader of the Republican Society of Charleston, even accused by the legislature of raising an expeditionary force to attack the Spanish for the French Republic. ${ }^{260}$ Moultrie reiterated

258. Such a view was offered, ironically enough, by Madison in 1784 , defending a Virginia statute that permitted the return of fugitives to foreign sovereigns. See Letter from James Madison to Thomas Jefferson (Jan. 9, 1785), in 7 THE PAPERS OF THOMAS JEFFERSON, supra note 146, at 588, 593-94; also in 8 THE PAPERS OF JAMES MADISON, supra note 57, at 227-28.

259. U.S. CONST. art. III, \& 2, cl. 3 ("The Trial of all Crimes, except in Cases of Impeachment, shall be by Jury; and such Trial shall be held in the State where the said Crimes shall have been committed; but when not committed within any State, the Trial shall be at such Place or Places as the Congress may by Law have directed.").

260. Alexander Moultrie's hopes for the French against the Spanish were accompanied by speculation in western land through the South Carolina Yazoo Company, see Moultrie v. Georgia (unreported case in 1795 Term), discussed in J. GOEBEL, HISTORY OF THE SUPREME COURT OF THE UNITED STATES: ANTECEDENTS AND BEGINNINGS TO 1801, supra note 60 , at 737-41, 757-59. On Moultrie's life, see J. NADELHAFT, supra note 248, at 34-36; E. MCCRADY, supra note 248, at 12, 717-19, 724; T. ABERNETHY, THE SOUTH IN THE NEW NATION, 1789-1819, at 107 (1961); J. WOLFE, JEFFERSONIAN DEMOCRACY IN SOUTH CAROLINA 43, 74-75 \& n. 22 (1940); ALEXANDER MOULTRIE, AN APPEAL TO THE PEOPLE ON THE CONDUCT OF A

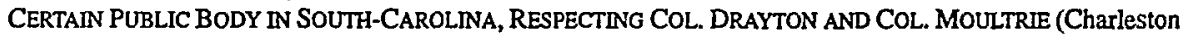
1794), available in EARLY AMERICAN IMPRINTS 1639-1800, supra note 116 (Evans No. 27354). 
Ker's argument with more eloquence. The Constitution was a social contract in which a "sacred residuum" of natural rights remained "in the hands of the people" and was "unalienable by any act of legislation." All the powers of the Constitution over life and liberty "are only a conditional cession of those rights to the care of society, under the advantage of a trial by jury of fellow-citizens, as the mutual safeguard and security of such rights so deposited." The jury could be seen as the arbiter of a higher constitution, an unwritten and unamendable natural constitution which stands supreme to the federal constitution as the federal stands to the state.

As to Robbins' actual past, argued Moultrie with perhaps too much worry, it should not be presumed any American citizen would voluntarily enlist in the British navy in violation of American neutrality laws. If Robbins was impressed rather than enlisting, an American held in unwilling service, then "it was meritorious, by the laws of God and man, to regain his liberty even by the death of his oppressors, and to avenge the insulted dignity of a free people." Vattel again did service for "the right of killing in war" to avoid enslavement. The warrant for interpreting the treaty to create a right of revolt was God, natural reason, and national honor. We "would ever hold an American unworthy the name of such, who would not sacrifice any one who, under the impious authority of any nation, would dare attempt to enslave him and rob him of his national privileges." Moultrie also mocked the factual affidavits as "vague, uncertain, ... amount[ing] to nothing more than mere suspicion."

The counsel for the British, John Ward, chided the defense for addressing "the passions of the auditory." The only decision was whether the demand for Robbins was "conformable to the treaty." A court could not decide whether the treaty "counteracted the constitution or not" in restricting access to a jury trial. Any question of constitutionality "had been long since settled, in the ratification of the treaty by the proper authorities." 261 A treaty is "co-ordinate with the constitution itself, and even paramount to it." aside, Ward barbed that "if the prisoner was really the American he pretended to be, he would have been able, before this time, to have made it appear more clearly."

Defense counsel did not respond to Ward's barb, and the omission was fatal. A late claim of citizenship might well seem suspect to a fact-finder who

261. It is worth reflecting why this argument might attract. Seen as a guardian of custom and mores, the Senate was shielded from immediate political passions by its longer staggered terms and indirect selection. The Senate could advise and consent to ratification of a treaty only by a supermajority, a more demanding decision rule than the Supreme Court itself. Is it only coincidence that constitutional review by the Supreme Court increases in frequency when the Senate begins to yield to direct election?

262. On August 1, 1799, the Charleston City Gazette published earnest letters from John Ward, from Alexander Moultrie and Samuel Ker, and from Judge Bee, stating that earlier published reports erred in ascribing to Ward the argument that treaties could be superior to the Constitution. Ward had only argued that treaties were "coordinate with" the Constitution, not "paramount to" it. The City Gazette and Daily Advertiser (Charleston, S.C.), Aug. 1, 1799, at 3, col. 1. Even so, a suggestion that treaties were not ruled by the Constitution was alarming to Republicans. 
could not know of defense counsel's lassitude in preparing for the hearing. ${ }^{263}$ Though consulted on the case long before, Moultrie never interviewed Robbins until the July 25 appearance. Ignorant of Robbins' claim of American nativity,

263. We may be surprised that Robbins had counsel at all, two centuries before legal aid. A partial account of how Robbins obtained counsel, and how they conducted the defense, came after the event, when Federalists charged the matter was inflated to serve French political ends. Abraham Sasportas, who had served as a prize agent for the French Republic in Charleston, detailed his early involvement in the case, protesting that it occurred by chance. He was "drawn to serve as a grand juror" in state court and was requested "to visit the gaol, in order to make a report of the state of the same." Letter of Abraham Sasportas to Messrs. Freneau and Paine (Dec. 5, 1799), City Gazette and Daily Advertiser (Charleston, S.C.), Dec. 5,1799 , at 3 , col. 1 . The grand jury complained to the Court of General Sessions of the Peace, Oyer and Terminer, Assize, and General Gaol Delivery of the poor state of the jail, "the subject of presentments from former grand juries for years past." Grand Jury Presentment, id., May 29, 1799, at 2, cols. 2-3. Federal prisoners were kept in the same lock-up, and so, in "the exercise of this duty, I [Sasportas] saw Robbins, confined in irons, who communicated to me the cause of his commitment and his defense to the charge, viz: that of his being an American citizen, impressed by the English. From his relation, and his certificate of citizenship then shown me, I was induced to employ counsel in his behalf, in order that his innocence or guilt might be established by an appeal to the laws of the country." Letter of Abraham Sasportas to Messrs. Freneau and Paine, supra. Sasportas' grand jury finished its service by May 20, 1799, so this is the date by which Robbins first voiced his claim of citizenship, if we are to credit Sasportas. Sasportas said he "spoke[ ] to . . . counsel the very day I saw the prisoner in jail." "[B]ut [counsel's] avocations, I presume, did not permit him to attend to the case. The consequence was, that rather than the cause should be wholly neglected, I applied to other counsel, with whose exertions I have no reason to be dissatisfied." Id.

Colonel Moultrie explained afterwards why he was among those who gave short shrift to the case until the last; Moultrie's frankness may come in part because he was warding off the different accusation of ideological adventure.

When I was first called on in Robbins's case, I considered it generally; and gave my opinion, that I thought such was the prevailing influence of opinions and sentiments of those in power, that every effort would be vain: he had not then been represented to me as an American citizen, and I considered the case on the point of jurisdiction only. I gave it but a short consideration, and soon determined, and thought no more of it. Matters rested thus for some days Imore than two months, we may note, if Moultrie was one of Sasportas' original counsellors], 'till the day before Robbins was tried: I was then accidently informed, in conversation with a friend, that Robbins was an American; I was struck and alarmed, to think I had deserted him. I immediately went to Mr. Ker, and desired him to prepare himself for the argument next morning. I went home and considered the case, and met Mr. Ker in court the next day.

I had never yet seen Robbins, nor had I ever had any intercourse with him, 'till he was pointed out to me, and I went up and spoke to him in court, the day of his trial; nor had I till then ever seen one of his papers. On my coming into court, amongst the first things I did, I asked the clerk for the papers, and amongst them found, Robbins's certificate of nativity and citizenship ....

Under these circumstances, sir, I undertook the cause of Robbins; a cause, sir, in which the rights of mankind and those of my country were deeply involved: a cause, sir, which I held myself bound in duty, as an American, to defend and support; which pointed at the constitution and vital principle of American independence. And give me leave further to tell you, that in this cause, I neither undertook it from any French influence or idea of advancing their interest, nor from the promise or expectation of any fee or reward; and that I never received any such.

Letter of Colonel Alexander Moultrie, id., Dec. 4, 1799, at 2, col. 2 (emphasis in original).

We have some unusual evidence to corroborate that only at the very last minute did South Carolina Republicans see the Robbins case as a possible vehicle of attack against the Federalists and the Jay Treaty. Philip Freneau happened to be visiting his brother in Charleston during June and July, 1799. Philip Freneau departed Charleston for Philadelphia on the schooner Ann on July 22, 1799, the day before Robbins' first appearance in court. The once and future "Robert Slender" would not likely have missed eyewitness of events he was later to satirize, had Charleston's Republican circle been alert to the proceeding. (Freneau's sea travels are logged in his copy of Robertson's Elements of Navigation, available in the Freneau Collection, Rutgers University Library, see L. LEARY, supra note 146 , at 311 .) 
Moultrie sent no inquiries to Trenton, New York or Connecticut, nor took any other step to corroborate Robbins' citizenship. Moultrie ventured at the hearing that "reference to the custom house" at New York might fix "the clearance and list of the crew" of the Betsey; the authenticity of the seal of the 1795 affidavit could also be settled by reference to New York; but Moultrie did not explain to Judge Bee why the inquiries had been omitted in the many prior weeks. Without a frank admission by Moultrie of his last-minute attention, Bee could well suppose that defense counsel had chosen for tactical reasons not to pursue matters that might backfire. Moultrie's only proffered corroboration was his personal surmise that the "Jonathan Robbins" signature on the 1795 affidavit resembled the signature signed in open court before Judge Bee. But the defendant had held the 1795 affidavit with him in jail, and certainly had time to practice penmanship. Moultrie did not press for any adjournment, and gave no explanation at all to the court why American citizenship was ventured only at the moment of delivery to the British.

\section{Judge Bee's Dispatch}

Even to a more willing listener than Judge Bee, Robbins' position posed a challenge. Pleading facts in the alternative is delicate enough in a lawyer's voice; in the defendant's voice it can be fatal to belief. Robbins swore in his affidavit "that he gave no assistance in . . . capture" of the ship by its crew, ${ }^{264}$ but through his lawyers insisted that he was entitled to use selfdefense. A claim of self-defense "falsifies his own plea of non-interference," complained a Charleston editorialist. ${ }^{265}$

The crucial chance of self-defense was dispatched by Bee with a passing air: Robbins had not proved he was impressed. Bee relied first on a feature of eighteenth century evidence law: the defendant's own testimony was not admissible. ${ }^{266}$ "I cannot but take this occasion to observe, that the two papers

264. 27 F. Cas. at 827.

265. The City Gazette and Daily Advertiser (Charleston, S.C.), Sept. 27, 1799, at 3, col. 1.

266. Criminal defendants were not permitted to testify under oath in their own defense, because they were thought to be impeached by their interest in the outcome. Sworn testimony by criminal defendants was excluded until surprisingly late. In England, defendants were admitted to testify under oath only by the 1898 Criminal Evidence Act, 61 \& 62 Vict., ch. 36. See Parker, The Prisoner in the Box-The Making of the Criminal Evidence Act, 1898, in LAW AND SOCIAL CHANGE IN BRITSH HISTORY 156, 157-58 (J. Guy \& H. Beale eds. 1984). In American state courts, the change came in the 1860's and 1870's. See, e.g., THE CONNECTICUT CIVIL OFFICER 164 (13th ed. 1877) ("In criminal cases, the accused party can now be a witress."); CONN. GEN. STAT., tit. 20, ch. 13, pt. 5, \& 7 (1875) ("Any person, on trial for crime, or the husband or wife of such person, shall, at his or her own request, but not otherwise, be a competent witness ...."). In American federal courts, defendants became competent witnesses only in 1878. See An act to make persons charged with crimes and offenses competent witnesses in the United States and Territorial Courts, 20 Stat. 30 (1878). See also Address of the Court to the Prisoner at the Bar, in THE TRIAL OF JOHN WILlIAMS, FRANCIS FREDERICK, JOHN P. ROG, NILS PETERSON AND NATHANIEL WHITE ON AN INDICTMENT FOR MURDER ON THE HIGH SEAS 90-91 (Boston 1819) (C.C.D. Mass. 1818, Circuit Justice Story and District Judge Davis) ("by the laws of this country . . . your own word cannot be taken as evidence in your favor"). 
produced by the prisoner, are only affidavits of his own, or a certificate founded on an affidavit, which are not evidence."267 The notarized certificate of 1795 was at best a prior consistent claim of American citizenship, and many foreign sailors carried such certificates as safeguard to allow access to American consuls' aid; the British complained of their fraudulent use. ${ }^{268}$ Robbins also had served as a warrant officer, "which impressed men are not likely to be entrusted with."269 Bee's inference was reasonable, though Robbins could have argued that there was no occasion for a British captain to disqualify him from petty office so long as he feigned contentment, that gaining trust was the likeliest way to make an escape. Bee then delivered his real complaint in a tone that will ring true to trial lawyers, who know judicial discretion is so often exercised in economy of time. Robbins' claims of citizenship and impressment could be discounted because they came late in the day.

It is somewhat remarkable, that a man of the name of Jonathan Robbins, with the paper produced in his possession, should continue on board a British frigate for a length of time, under another name, and acting as a warrant officer, which impressed men are not likely to be entrusted with, and that he should afterwards take the name of Nathan Robbins, and lay in jail here five or six months, without the circumstance being made known until now. ${ }^{270}$

Bee's inferences were arguable on the record known to him; in light of Mrs. Martin's affidavit of 1798 we may even conclude they were correct. One's complaint is with Bee's willingness to proceed on so slender a record, and with the insupportable silence of defense counsel who failed to remark that Robbins had no earlier way to communicate a claim of citizenship from his isolated custody in the local jail.

Judge Bee's impatience with the late claim of citizenship was fathomable. Bee had already represented to the Secretary of State that things were well on

Jurists seemed puzzled how to regard the defendant, since a convicted felon was disqualified as a witness. The accused had an irresistible motive to lie, and if he was "in fact" guilty, why should he benefit by the law's delay in declaring his testimonial disqualification and distort the outcome by convincing perjury? In one state, even after defendants were admitted to testify generally in misdemeanor trials, those accused of perjury or forgery were still excluded. See 1872 Pa. Laws 34 (added Apr. 3, 1872). See generally Bodansky, The Abolition of the Party-Witness Disqualification: An Historical Survey, 70 KY. L.J. 91 (1981); 2 J. WIGMORE, EviDENCE § 519 (J. Chadbourn rev. ed. 1979); Ferguson v. Georgia, 365 U.S. 570 (1961).

267. The original of Bee's opinion, if it was written out, does not survive. The text's account of Bee's opinion is based upon the contemporary newspaper reports, which were reprinted in Federal Cases. United States v. Rob[b]ins, 27 F. Cas. 825, 832 (D.C.S.C. 1799) (No. 16,175).

268. See J. ZIMMERMAN, IMPRESSMENT OF AMERICAN SEAMEN 35 (1925).

269. 27 F. Cas. at 832. In later defense of Bee's decision, Federalist editor John Fenno turned Robbins' warrant office to different effect: Even assuming Robbins had been impressed, he had "touched often at ports in the West Indies" where he could have applied to American consuls for help or made his escape, if "the disposition had not been wanting"; "on the contrary, he was made a warrant officer on board the ship; which implies his consent thereto." Gazette of the United States (Philadelphia, Pa), Aug. 22, 1799, at 3 , col. 2 (emphasis in original).

270. 27 F. Cas. at 832 (emphasis added). 
their way. The very privity of Bee's address to Pickering ${ }^{271}$ could create a sense of beholdenness not accompanying judicial opinions announced at large. And there is the self-consciously practical sense we should wish in our judges only with ambivalence. Bee had the case under advice for more than three months. In April 1799 the British dispatched a cutter to pick up Robbins, with Lieutenant John Forbes aboard to identify him. Bee's reference of the extradition request to the Department of State-putting British Consul Moodie to seek the assistance of Minister Liston, who in turn corresponded with Secretary Pickering and the President-occasioned a month or more's delay, and the British cutter left Charleston in the interval. On July 1 the turn-over was delayed until a new vessel could arrive. By July 23, a British officer (appropriately named Lieutenant Jump) was now waiting on His Majesty's sloop Sprightly in Charleston Harbor to take Robbins to Jamaica. It was the middle of a British naval campaign; a French invasion of Britain was still possible, and the British navy still served as unspoken surrogate in balance to the French in the absence of any adequate American navy. If jurisdictional scruples were at stake concerning what judge or court should make the turn-over, it was late to recognize them; the spring term of the South Carolina Federal Circuit Court had come and gone, and the Circuit Court would not meet again until late October 1799.272 There was also perhaps a sense that the nature of the charged crime spoke against too luxurious procedure in rendition. Robbins conceded he had been aboard the Hermione during the mutiny, and the excess of violence drained the argument of self-defense of its attractive aspect. ${ }^{273}$ A stalwart devotion to due process, nerve to discomfit a treaty partner, some sense of immunity toward martial fortunes and greater sympathy for Robbins would have been required for further delay-yet we must surely fault Bee for proceeding with imprudent haste. ${ }^{274}$ The claim of Robbins' service on the American ship Betsey might have been capable of verification and Robbins' claim of Danbury residence also explored.

271. See supra page 294.

272. See An Act concerning the Circuit Courts of the United States, \& 1, 1 Stat. 517-18 (1797).

273. "An Observer," Iater writing in the Charleston City Gazette, argued that proof concerning the mutiny would have been almost tendentious-for "The mutiny of the crew, the fate of the officers; in short, the whole dismal transaction relating to the vessel, are public and notorious facts, which now require no more particular evidence than the burning of Cape-Francois, or the death of Louis XVI." For a sailor, argued the Observer, "mere presence" during a mutiny should suffice as proof, when only commitment for trial was at stake. "[W]hich of you, as a magistrate, would have thought his conscience clear in refusing to commit ...?" The City Gazette and Daily Advertiser (Charleston, S.C.), Sept. 27, 1799, at 2, cols. 1-2.

274. Perhaps a sign of things came in a colleague's assessment of Bee's temperament during Bee's service in the Continental Congress: "[Lieutenant] Governor Bee of South Carolina is a Man of some Talants," said Delegate Thomas Rodney to his Diary in 1781, "of a cruid restive Temper[,] not Eloquent but of a harsh \& disagreable dilivery; consiquensial in his deportment and Conceited in his notions-very desirous of Order in the House, but Most abt to transgress it himself." Diary of Thomas Rodney (Mar. 8, 1781), at 27, in RODNEY PAPERS (Library of Congress); also in 6 LETTERS OF MEMBERS OF THE CONTINENTAL CONGRESS 19, 20 (E. Burnett ed. 1933 \& reprint 1963) (miscites entry as Mar. 10, 1781, with slight textual variations). 
The fervor of the jurisdictional, constitutional and treaty arguments seemed, in part, to have deadened Bee to the facts. Steeled by his sense that the resistance was a political attack on the treaty, not realizing the historical mudhole into which he was hurling his reputation, Judge Bee proceeded with the record he had. Bee intoned, "[W]arm and pathetic appeals to the passions were made on some of the old grounds of opposition to the treaty, which I endeavored to check." Bee recited the many claims made against the treaty-that trial by jury was guaranteed to citizens, that the treaty only permitted rendition of foreigners, that the courts of the United States should take jurisdiction over crimes on the high seas, that a grand jury should make the inquest ${ }^{275}$ —ending with a recitation of his duty.

[A]s this treaty has been ratified agreeably to the express provisions of the constitution, and is therein declared to be the supreme law of the land, and I am religiously and solemnly bound by the oath I have taken to administer justice according to the constitution and laws, it is not in my power, nor is it my inclination, ever to deviate therefrom. ${ }^{276}$

In Bee's lights, the United States did have concurrent jurisdiction over the crime of murder when it was committed on the high seas, even by a foreign actor on a foreign ship. But the treaty gave Britain the right to demand delivery despite concurrent jurisdiction. Bee's conclusion was avowedly based on the treaty text, and analogy to American constitutional provisions that favored trial at the locus delicti. ${ }^{277}$ Witnesses would be more readily available at the seat of the British navy. ${ }^{278}$ With dozens of mutineers unapprehended, it may have seemed slightly untoward to have the surviving witnesses sailing from place to place to give testimony in local trials at each site of capture. One might even have a sense of unequal justice-why should some mutineers be tried by courtmartial and others by jury, depending upon their place of capture? American citizens were liable to rendition as much as British by the plain language of the treaty, concluded Bee, since Article 27 referred to "all persons." Robbins" claim of American citizenship did not exclude him from the treaty.

Bee did not recite the President's advice as the basis of his decision. ${ }^{279}$

275. Bee noted that even for domestic trials, presentment by grand jury was not required for cases arising in the naval forces in actual service in time of war or public danger. 27 F. Cas. at 832; see U.S. CONST, amend. $\mathrm{V}$.

276. $27 \mathrm{~F}$. Cas. at 832.

277. The extradition article of the Jay Treaty was "founded on the same principle with that part of the constitution which declares, that the trial for a crime shall be held in the state where it shall be committed." Id.; see U.S. CONST. art. III, § 2, cl. 3.

278. Bee's descent toward historical perdition is signalled in one thoughtless phrase of his opinion: Article 27 served "the furtherance of justice" because otherwise "it would be difficult to procure evidence to convict or acquit." $27 \mathrm{~F}$. Cas. at 832 (emphasis added). But if the defense was impressment, Bee seems not to have realized, corroboration of the defense would be far harder to obtain at a shipboard court-martial in the West Indies than on native soil. See also infra p. 353.

279. In 1810 , Judge Bee's admirers published a volume of his admiralty opinions, and included for the Robbins case a previously unreported variant of his memorandum order. This newly recited that delivery 
But Secretary Pickering's June 3, 1799 letter was provided to counsel for both sides. Pickering must surely be faulted for omitting to advise Judge Bee that the American Executive's reading of the jurisdictional scope of the treaty had changed. The very experience of inconstancy in interpretation may dissuade courts from yielding deference; insofar as treaties function as domestic law, they must take on the stability of law. The Official Opinions of the Attorneys General were not published until 1841, so that without advice from Pickering, or information from counsel concerning the facts of the Brigstock case, Judge Bee could not have known of the change of position by the Executive.

On procedure to implement the treaty, Bee admitted frankly his own change of view, first believing the matter was for Executive decision, now holding it was a judicial question.

When application was first made, I thought this a matter for the executive interference, because the act of congress respecting fugitives from justice, from one state to another, refers it altogether to the executive of the states; ${ }^{280}$ but as the law and the treaty are silent upon the subject, recurrence must be had to the general powers vested in the judiciary by law and the constitution, the $3 \mathrm{~d}$ article of which declares the judicial power shall extend to treaties, by express words. ${ }^{281}$

Bee was not a law teacher, and wrote no tomes on law, so we cannot outline his general jurisprudence. But Bee, like some others of his generation, may have believed that federal courts could look beyond Congress for the scope of their jurisdiction. With no "arising under" jurisdiction assigned to lower federal courts in the 1789 Judiciary Act, Bee's reference to judicial power extending to treaties may rest on the notion of constitutional self-execution, that Article III directly empowers federal courts, or upon the now wholly unfamiliar notion that treaties can act directly as "law" in lieu of legislation to create jurisdiction in inferior federal courts. ${ }^{282}$ Bee's explanation has the tone of Marshall in Marbury v. Madison: there must somewhere be federal judicial power to give effect to claims under federal law; jurisdiction and remedial justice must be presumed complete. "The judiciary have in two instances in this state, where no provisions were expressly stipulated, granted injunctions to suspend the sale

of Robbins was made "in consideration of the circumstances and at the particular request of the president of the United States [Mr. John Adams] . . . " Compare REPORTS OF CASES ADJUDGED IN THE DISTRICT COURT OF SOUTH CARolINA BY THE HON. THOMAS BEE 266 (Philadelphia 1810) (emphasis in original) with United States v. Rob[b]ins, 27 F. Cas. at 833.

280. Art. IV, $\S 2, \mathrm{cl} .2$ of the Constitution makes intra-Union extradition solely a matter between state executives, Bee noted. The Act of Congress implementing this clause "required only a bill [of indictment] found, or an affidavit charging them with the offence." 27 F. Cas. at 832; see An Act Respecting Fugitives from Justice, and Persons Escaping from the Service of their Masters, § 1, 1 Stat. 302 (1793).

281. 27 F. Cas. at 833 (emphasis and footnote added).

282. Bee's allusion also may be to his capacity to interpret the treaty independently of the Executive, once the court had jurisdiction. 
of prizes under existing treaties. If it were otherwise, there would be a failure of justice."283

Bee finally took his faultiest step, ${ }^{284}$ concluding "that from the affidavits filed with the clerk of the court, there is sufficient evidence of criminality to justify the apprehension and commitment of the prisoner for trial."285 Bee ordered Robbins to be delivered over, and, in a brusque closing of the tale, it is reported that Robbins was soon beyond the reach of American habeas corpus.

The judgment being pronounced, the court was immediately adjourned; the irons were replaced on the prisoner, and he was delivered over by the constables, to a detachment of federal troops, who had before been placed under arms opposite the court house, and had continued there during the sitting of the court. The troops immediately delivered up the prisoner to Lieut. Jump, of his Britannic majesty's sloop Sprightly, then lying in this harbour, and which sailed with the prisoner on Saturday morning for Jamaica. ${ }^{286}$

Robbins did not survive long under the rigors of British due process. By Thursday, August 15, 1799, he was in Jamaica and his trial was begun. ${ }^{287}$ By Monday, August 19, 1799,288 Robbins had been executed and hung in chains "agreeable to the sentence of a court martial." Most agreeably, too, Robbins "confessed himself to be an Irishman" before his execution, said Admiral Parker's letter to English consul Benjamin Moodie, reported in the Charleston and Philadelphia press. ${ }^{289}$ To reconcile American public opinion, Parker fur-

283. Id.

284. Bee did not perceive that in popular government it is not sufficient to dispose of a matter as one thinks correct; rather, a record must be made so that others will be brought to the same conclusion. Bee, like other judges in other times, may have been too apt to tax the defendant with counsel's misjudgments. And Bee did not perceive that the ordinary evidentiary standards of a binding-over would not suffice for a natural rights defense available only in American hearing. See infra page 353.

285. 27 F. Cas. at 833.

286. $I d$.

287. See Proceedings of a Court Martial Held on board His Majesty's Ship Hannibal in Port Royal Harbour Jamaica on Thursday the 15 August 1799 for the Trial of Thomas Nash one of the Mutineers of His Majesty's late Ship Hermione (British Public Record Office, Adm. 1/5350); see also New Brunswick Guardian or Advertiser (New Brunswick, N.J.), Oct. 1, 1799, at 2, col. 3 ("Kingston. In the cutter Sprightly, which arrived on Sunday from Charleston, was brought one of the principal mutineers belonging to the Hermione frigate- he has been long confined in America, and has been given up to suffer the punishment due to his crimes.").

288. See Sentence of a Court Martial on Jonathan or Nathan Robbins, alias Thomas Nash, one of the Mutineers, Pirates and Murderers belonging to His Majesty's late Ship Hermione (British Public Record Office Adm. 1/5350) (inscribed in verso, "This Sentence to be carried into excecution Monday Morning").

289. Letter from Vice Admiral Sir Hyde Parker to Charleston Consul Benjamin Moodie (Sept. 13, 1799), in The City Gazette and Daily Advertiser (Charleston, S.C.), Dec. 4, 1799, at 2, col. 1; also in Aurora (Philadelphia, Pa.), Dec. 20, 1799, at 2, col. 5; Virginia Argus (Richmond, Va.), Feb. 25, 1800, at 3, col.4; see also Letter from Admiral Parker to the Admiralty (Oct. 8, 1799), in "IN-LETTERs," ADMIRAL's DISPATCHES, JAMAICA (British Public Record Office, Adm. 1/249) ("Nothing material has taken place under my Command since my Letter of the 3d August . . . except the Executive Government of the United States of America having come to the resolution of delivering up the Villain Thomas Nash late of His Majesty's Ship Hermione; he was tried, and agreeable to His sentence, hung, and his body afterwards hung in chains."). 
ther reported on British naval bookkeeping; the Hermione's books (sent to the Admiralty at intervals during its voyages) reflected Thomas Nash was a native of Waterford, Ireland, who volunteered on December 21, 1792, for three pounds bounty money, and reported to the Hermione on January 28,1793 . Whether the books of British ships were reliable business records when kept by captains with short crews, the Admiral did not say. British Commander George Hans Blake, present at the court-martial, recounted that four witnesses knew Robbins always as Thomas Nash and "fully prove[d] that Thomas Nash was the person who killed lieutenant Foreshaw." At the trial, no defense was offered, "nor did he at any time of the trial call, or endeavor to prove himself a subject of the United States of America." 290

The report by Commander Blake of the course of the trial was reasonably accurate, if we credit the surviving Admiralty transcript. ${ }^{291}$ Three witnesses from the Hermione identified Robbins as Nash: carpenter's mate John Mason, seaman John Brown, and cook John Holford. Lieutenant Forbes of the Hermione earlier made an identification in Charleston. ${ }^{292}$ The lack of fuller evidence from carpenter's mate Mason makes one oddly more confident in the transcript; Mason heard "by Holford" that Nash "hove overboard" Lieutenant Foreshaw, but disclaimed direct knowledge. Brown and Holford were eyewitnesses. John Brown testified that he observed Nash tell three crew members to "heave [Foreshaw] overboard; which they did, and hove him over the Quarter." John Holford testified that he saw Nash with "some weapon in his hand one time"; when Lieutenant Foreshaw crawled back in a porthole after an initial beating by persons Holford could not identify, with "blood ... streaming down his face from his head," Thomas Nash caught Foreshaw by the right wrist. Said Nash to Foreshaw: "[A]re you not overboard yet? Overboard you must go, and overboard you shall go." Holford saw Nash and another take Foreshaw to the Larboard Gangway and throw him into the sea.

Robbins offered "no Defense or Evidence" according to the transcript, but did ask a question of John Brown-apparently hoping to argue he had planned to retake the ship. The question worked out badly, as Figure $\mathrm{A}$ will reflect.

290. Affidavit of George Hans Blake (Nov. 27, 1799), in The City Gazette and Daily Advertiser (Charleston, S.C.), Dec. 4, 1799, at 2, col. 1.

291. See Proceedings of a Court Martial Held on board His Majesty's Ship Hannibal in Port Royal Harbour Jamaica on Thursday the 15 August 1799 for the Trial of Thomas Nash one of the Mutineers of His Majesty's late Ship Hermione, supra note 287. The transcript does not reflect any question put to witnesses whether Nash ever "assume[d] any other name," unlike Blake's recollection of the trial.

292. Lieutenant Forbes swore that the man in the South Carolina jail was "a seaman on board the Hermione British frigate . . . personally known" to Forbes during his own seven-month service. Forbes stated that he "believes" the man's "real name ... to be Thomas Nash," thereafter referring to Robbins as "the said Nash." Cress, supra note 6, at 101, 116, overpresses in taking this as suggestion that Forbes "could not positively identify [Robbins] as Thomas Nash." 


\section{FIGURE A:}

Portion of Testimony of John Brown and John Holford, from Transcript of Proceedings of a Court Martial Held on board His Majesty's Ship Hannibal in Port Royal Harbour Jamaica on Thursday the 15 August 1799 for the Trial of Thomas Nash one of the Mutineers of His Majesty's late Ship Hermione (British Public Record Office, Adm. 1/5350), at p. 7. 


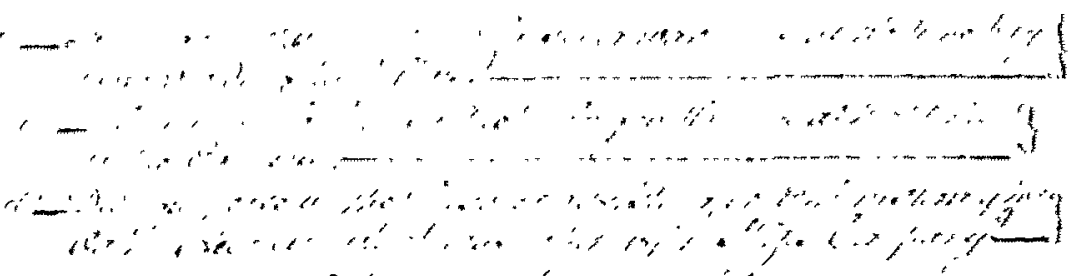

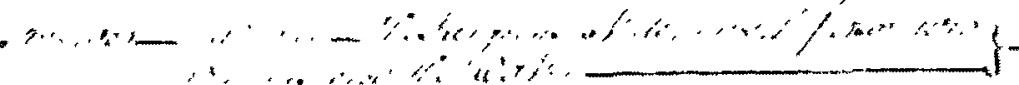

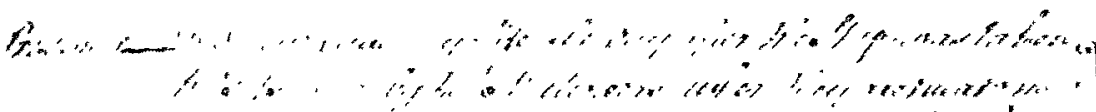

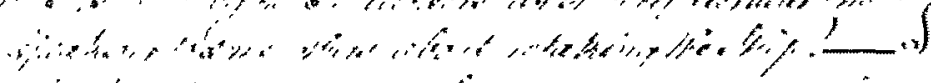

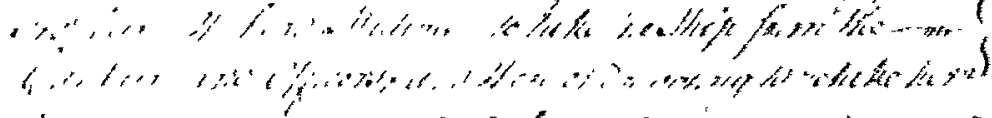

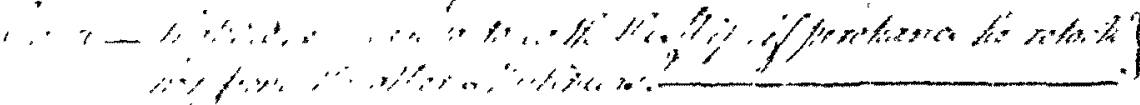

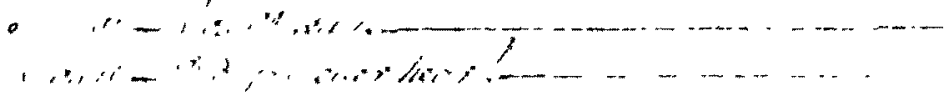

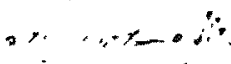

1" " " , ".,

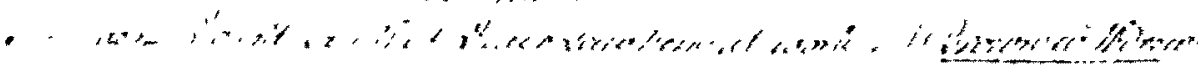

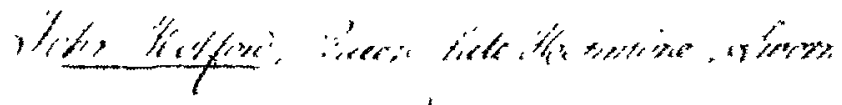

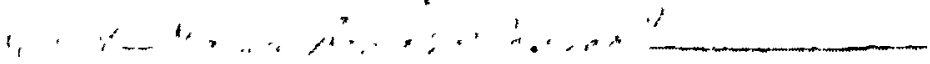

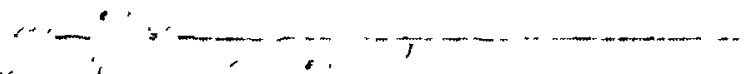

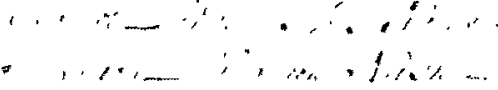

-

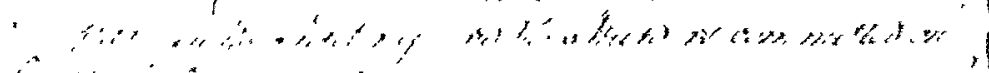

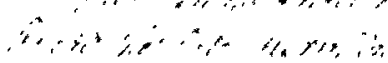

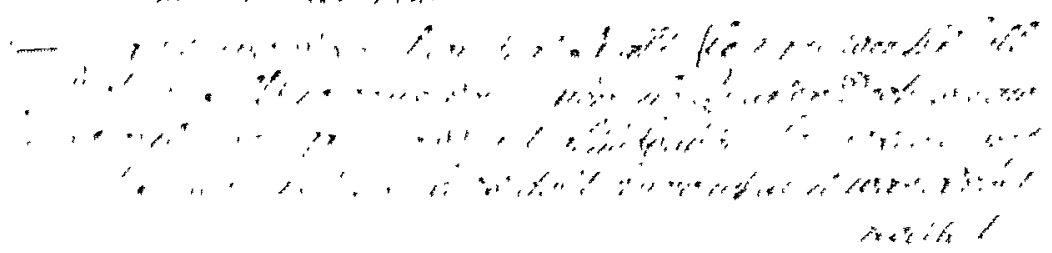


Robbins' question was knocked out of his hand by witness Brown.

Prisoner-Did you save my Life the day after the Ship was taken possession of by the Mutineers; when they overheard me speaking to some others about retaking the Ship?

Answer-I heard a Rope was rove to hang you, on account of your first being the head Mutineer to take the Ship from the Captain and Officers; and then endeavoring to retake her.

Court-What did he mean to do with the Ship, if perchance he retook her from the other Mutineers?

Answer-I can't say. ${ }^{293}$

The ship's surviving muster books, sent to Admiralty, indeed record that Nash was born in Waterford, Ireland, entered service at the beginning of the Hermione's cruise in December 1792 when he was twenty-five years of age, receiving bounty money of three pounds. ${ }^{294} \mathrm{~A}$ Waterford birthplace would not preclude subsequent naturalization as an American, but Robbins is once again harmed by inconsistencies: his affidavit in Judge Bee's court claimed he was born in Danbury, Connecticut-an American by soil as well as allegiance.

\section{Brigstock and Robbins: Why the Difference?}

In reconstruction of the Robbins affair, the first puzzle is why Brigstock and Robbins were decided so differently. Pickering, one can argue, maintained a personal consistency, urging in Brigstock that Charles Lee re-examine the evidence to see whether a case of murder or piracy could be made out, declining to put the United States on record as refusing extradition in the escapade of the April 13 note that was never sent, and in Robbins case urging his preferred course in light of the difficulty of obtaining viva voce testimony for United States trials of foreign events. Adams plainly knew that the treaty decision proposed in Robbins reversed the prior course of Brigstock: Pickering told him

293. Id. The original transcript page is reproduced in Figure A. Robbins' muteness at the court-martial did not follow from lack of opportunity. Other Hermione defendants submitted written memorials seeking clemency. See, e.g., Memorial of John Williams (Mar. 1799) (British Public Record Office, Adm. 1/5348) (pleading defense of non-involvement; attestations of good character from six shipmasters); Statement of John Barnett (July 23, 1799) (British Public Record Office, Adm. 1/5350) (claiming youth and duress). Robbins' active role in the mutiny is corroborated by testimony offered at other courts-martial. For example, Midshipman David Obrien Casey testified at a court-martial in March 1799 that he was below deck during the mutiny when Thomas Nash "came in making use of very bad language and desired the Purser and Surgeon to prepare themselves for Death against the next Morning, for the Ships Company were determined against letting them live." See Proceedings of Court Martial of John Williams, et al. (Mar. 13-15, 1799) (British Public Record Office, Adm. 1/5348).

294. It is harder to tell what to make of the muster book's column entries for "Whence and whether Prest or not." The column is frequently left blank and when a town or ship is filled in as the place of mustering, it is usually accompanied by "vol" or "do", for "volunteer" or "ditto". See, e.g., HERMIONE MUSTER BOOK (OCT. 31, 1796-FEB. 10, 1797), supra note 175. The entry for Thomas Nash records a ditto mark in the column, following an entry for John Conley reading "Dover Do", in turn apparently referring to an entry above recording "vol". 
so. Why Adams did not pause over the reversal may be the sense that in a new government it is unwise to value consistency too early, until one sees what works. It may have been a desire to maintain faith with Britain in execution of the Jay Treaty at a time when the negotiations of the claims commissioners were not proceeding smoothly. Fear of war with France mounted in a martial flush from 1798 to 1799 , not to be fully abated until the renewed mission to France brought back a new treaty in December 1800; the sense of possible dependence on British protection made the fate of the British navy a matter of some interest; the British diplomat Robert Liston was the agent of small favors for an Administration fearful of French attack, including a gift of cannon from Nova Scotia to protect the harbor at Charleston; British cooperation promised the safety of a renewed American trade to Santo Domingo. American domestic disorder had renewed itself in March 1799 in Fries Rebellion against the very taxes meant to fund an American army; popular opinion might not accept the costs of mounting a full defense against the French. Adams too might have felt an implicit license to treat an alien criminal summarily under the Jay Treaty because of his legislated emergency powers to exclude aliens under the Alien Act.

In reading the actual exchange of views between Pickering and Adams, we may be inclined to believe that the reversal of opinion from Brigstock to Robbins seemed simply of little consequence at the time. There is no record of strong British pressure or a sense of portentous decision. This was a small matter, dispatched almost routinely in the press of other business. A regular reader of the Aurora could have warned Adams that Hermione was a notorious ship, that aiding its discipline would delight Republican poets. But Adams was not known for his ability to gauge public mood, to judge how something might suit hostile rhetoricians. Inattention in the Jay Treaty debates to the matter of fugitive delivery gave Adams no alert of what was to come. Pickering did nothing to warn Adams that he was landing on a snapdragon. Pickering's sharp dealing in Robbins came in excluding Charles Lee from the deliberation, a voice that might have warned Adams of the political potency of the event. Pickering's rebuff to Lee was made especially easy by Adams' remove from the capital in the critical month of the Robbins decision. Adams' residence in Quincy, Massachusetts, was his summer habit, and a sensible precaution against the yellow fever epidemics that frightened Philadelphia in the summer months of 1798 and 1799; and yet his absence from the capital also served as ready symbol of the ministerial intrigue that might exploit any reserve of Executive power; courtiers' machinations could impugn Executive integrity as much as faction sullied Congress. ${ }^{295}$

295. Cf. Letter of Uriah Forrest to John Adams (Apr. 28, 1799), in 8 THE WORKS OF JOHN ADAMS, supra note 193, at 637 ("The public sentiment is very much against your being so much away from the seat of government .... The people elected you to administer the government. They did not elect your officers."); Letter of John Adams to Uriah Forest (May 13, 1799), in id. at 645-46 ("I do administer it here 
Neither Adams nor Pickering had any advice that the sailor in the Charleston affair claimed to be American, as the timing of the decision shows. The error lay in failing to inquire, omitting to take precaution, supposing that stewardship of public business only requires a decision correct on the presented facts, rather than demanding of oneself the gift of anticipating what might be lacking in the record and what might fire popular imagination. Adams was, in a sense, too much the administrator, too little the poet. Freneau's verse would outrun the painstaking defense of a President untuned to popular temper. His Rotundity would be no match for Robert Slender.

Was "Robbins" an American? From the record available to us, rather clearly he was not. There is no question that the man arrested in South Carolina served on the Hermione; he admitted as much in his affidavit sworn before Judge Bee, ${ }^{296}$ and he served under the name Thomas Nash according to four witnesses. The muster book records that Thomas Nash signed on to the Hermione at the beginning of her voyage from England in 1792, giving his birthplace as Waterford, Ireland. There is no sailor of the name Jonathan Robbins or Nathan Robbins in the muster book, even as it recorded the names of other men who were pressed, nor any man claiming a birthplace of Danbury, Connecticut, as Robbins did in his affidavit before Judge Bee. ${ }^{297}$ There was no reason for Frances Martin to lie about the nationality of "Thomas Nash, an Irishman" a full year before he was caught. And on May 20, 1795, when a "Jonathan Robbins" swore an affidavit of citizenship in New York City before notary John Keese, ${ }^{298}$ the Hermione was in harbor in the West Indies and the muster

at Quincy, as really as I could do at Philadelphia. ... The post goes very rapidly, and I answer by the return of it, so that nothing suffers or is lost.").

296. See United States v. Rob[b]ins, 27 F. Cas. at 827. Robbins' own admission that he was aboard the Hermione helps soothe concern about command pressure on the witnesses at the court-martial. Sir Hyde Parker was, undoubtedly, out for blood in seeking the conviction of Hermione mutineers. See, e.g., Letter from Sir Hyde Parker to the Admiralty (May 28, 1798) (asking Admiralty Lords "to remove Rear Admiral [Richard Rodney] Bligh from under my Command" for "supineness . . . in the decisions of the Courts Martial he has been at the Head of."), in "IN-LETTERs," ADMIRAL's DISPATCHES, JAMAICA (British Public Record Office, Adm. 1/249).

297. The British proved not particularly shy about recording members of the crew who came from the United States. Even after the Neutrality Proclamation of April 22, 1793, the muster book continues to record sailors born in American towns and cities, including at least two said to have volunteered. The South Carolina defendant must have had some name during his tenure on the Hermione; the name Jonathan Robbins is not on the ship's books; four witnesses call him Thomas Nash; and the only Thomas Nash on the ship's books was mustered from 1792 on, long before the date when the South Carolina defendant claimed to have been impressed from the Betsey by Captain Wilkinson of the Hermione.

If our protagonist was conceivably an American, he was not Jonathan Robbins born in Danbury, but an American who enlisted for British naval service in 1792 claiming an Irish birthplace, who may have acquired a protection affidavit as insurance in case he ever needed an exit. Any Hermione sailor was keenly aware of the advantage of bartering for an American certificate of protection or other indicia of nativity: In May 1796, three members of the Hermione crew were released from British service by the intercession of American diplomatic or consular aid, "claimed as citizens" of the United States. In April 1797, at least eight more made a similar exit. See HERMTONE MUSTER BOOK (APRIL 7-JULY 7, 1797) (entry nos. 560, 561, 563; and nos. 512, 513, 515, 518-20,607, 667), supra note 175 . Our protagonist also may have acquired the protection certificate after the Hermione mutiny, when use of a new name became prudent.

298. The originals of the affidavits in the Rohbim- rase-the May 20,1795, New York City affidavit, 
book records that Thomas Nash was aboard. ${ }^{299}$ But the only American inquiry into citizenship prior to Robbins' delivery and death was by Judge Bee in his one-day hearing, and Bee knew few of these facts. Bee's own reasoning was plausible, but made on a record woefully insufficient. Bee, Adams and Pickering all dangerously disregarded the chance that any Hermione sailor might be an American. Yet what should be astonishing to us is how rhetoric will manage to outrun the immediate facts in the mishap of the Robbins affair; the historical role assigned to Adams was what men wished to believe of him.

\section{METONYMY AND MARTYRDOM}

As Butterfield cautioned of English history, ${ }^{300}$ so we should heed in American constitutionalism. We read the past with democratic eyes, placing in the beginning what we prefer in our own time, taking the egalitarianism of the Declaration, le quatorze juillet and the Fourteenth Amendment, of Andrew Jackson, populism and the New Deal's safety net, of the Fifteenth, Nineteenth and Twenty-Fourth Amendments, of direct elections and Baker v. Carr, as the authentic and inevitable path of American thought, drawing a curve that fits these data points, casting others out as aberrant. Confrontation with the Constitution's early text always provides the first shock; even apart from slavery, 1787's inscriptive act startles with its agnosticism. How the federal government is to be ruled is left largely to the states. The qualification of voters for the House of Representatives, the appointment or election of Presidential electors, the method of choice of United States Senators, is left to the discernment of the state legislatures, whose own selection is, at most, loosely constrained by the justiciable federal constitution. ${ }^{301}$ Article IV guarantees that states must assume a Republican form, but the shape of Republicanism is left to be defined. Political culture and state constitutionalism will gradually extend suffrage from freeholders to most white males, bring direct election of states' Presidential electors after outcry at the "Corrupt Bargain of 1824," and spread the popular choice of Senators, through preferential primary laws, until 1913's Seventeenth Amendment textually confirms emergent practice. If we wish to

and the in-court July 25, 1799 affidavit-do not survive, but as suggested above, supra page 299, any resemblance in the signatures would be met by the defendant's long opportunity to study and imitate the 1795 signature.

299. See D. Pope, supra note 6, at 276; Hermione MUSTER BOOK (MAY 1-JUNE 30, 1795) (British Public Record Office, Adm. 36/12010) (entry no. 179). The Hermione was "At Anchor at Port au Prince." See Entry for May 20, 1795, in A JOURNAL OF THE PROCEEDINGS OF H.M. SHIP HERMIONE FROM THE 5 SEP. 1794 TO THE 20TH SEP. 1795 BOTH DAYS INCLUDED[,] PHILIP WILKLSON ESQ CAPTAIN (British Public Record Office, Adm. 51/1104). Nash is noted present in musters taken on May 15 and 22, 1795 by Captain Willinson.

300. See Herbert ButTerfield, The Whig InTERPRETATION OF History (1931 \& reprint 1963).

301. We are so abruptly reminded of this in Dorr's Rebellion against the Rhode Island Charter Government. See Luther v. Borden, 48 U.S. (7 How.) 1, 42 (1849) (Taney, C.J.); Pacific States Tel. \& Tel. Co. v. Oregon, 223 U.S. 118 (1912). 
see the source of change, how the working Constitution became an instrument of direct democracy, to see what motivated resistance, even to inquire what other paths might have yielded in public virtue and vice, then we must address and teach events of political history and political thought, the losing side as well as the victors, as crucial in American constitutionalism as among textless Britons. As fin-de-millénaire democrats, in the torpor of positivism, with sovereign will accepted as the source of law because we believe the will is our own, we are distracted from the task of recognition and creation that faced the first generations. For what we choose to call the Founding was so evidently incomplete, and, to a country that balanced Enlightenment optimism with the darker tones of Calvin and Augustine, immediate will was not anodyne.

When we read the 1787 text with this in mind, it becomes clearer why an affair plain as the Hermione mutiny might invite metonymy. After the revolutions of England and France, the body politic no longer served so well. A body is differentiated, and democrats do not wish to concede different orders of men; a body must have a head, and the regicides had severed it. The Hermione affair recalled another way to imagine problems of governance. It could be the Nina, Pinta, and Santa Maria, the Pilgrim's Compact, the ship to Massachusetts Bay, or the New Republic's dependence on seaborne commerce to sell the fruit of its soil and obtain manufactures. The sailor was the yeoman of a republic that was as commercial as agrarian. ${ }^{302}$ The ship of state, a venture governed by contract, with its parts differentiated by task rather than morphology, fit the American case. And jurisdictional confusion in who should speak law to violence, or remedy lapses from grace committed out of sight of land, reached the point of anxiety in American thought-whether to claim connection to the fallen world of Europe, or to re-create Eden with historical amnesia.

The passions that surrounded this simple case were not surprising in the setting. The French example had left-flanked American democrats, exposing the American republic's whiggish difference, forcing one to ask, sooner than contemplated, why there was not direct and immediate democracy in all forms of governance. The frights of the Terror and the battery of France's pugnacious foreign policy forced all to wonder at the consequences of radical leveling. Washington's declaration of neutrality was not only war avoidance, but an autarkic wish to grow a native politics, free from the accumulated temper and grudges of aging regimes. A Constitution lacking its own center of democratic gravity might be drawn into one orbit or the other, in the polarity of AngloEuropean contest. Foreign suitors in American politics seemed only too evident, in the call of Genêt for popular mobilization, the resignation of Edmund

302. Cf. PHILIP FRENEAU, The Rising Glory of America (1771), in POEMS ON SEVERAL OCCASIONS 36, 42 (Monmouth, N.J. 1795) ('No nation e'er grew social and refin'd / 'Till Commerce first had wing'd the adventurous prow, /. . . / Great is the praise of Commerce, and the men / Deserve our praise, who spread the undaunted sail"); see also J. APPLEBY, CAPITALISM AND THE NEW SOCIAL ORDER: THE REPUBLICAN VISION OF THE 1790s (1984). 
Randolph following his French connection, the electioneering and western intrigue of Minister Adet, and the blandishments of the "ever-agreeable" Robert Liston, suspected of sharing British secret service money with legislative placemen and editors, intriguing with Senator Blount for a settler and Indian expedition against the Spanish in the Mississippi valley. The adder tongues of newspaper scribes, Federalists Cobbett and Fenno, Republicans Callender, Bache and Duane, seemed to corroborate that the people would not be left to form opinions on their own. The editors seemed so often to have a foreign tie, Cobbett as Briton, Callender as disaffected Scot already prosecuted in England for seditious libel. Corrupting foreign ties seemed close at hand-to be drawn into endless war in aid of France, to be left commercially prostrate at England's feet by the Jay Treaty's guarantee of obstructed prewar debts limited only by the commercial conscience of treaty commissioners, fundable through property and excise taxes that would fall so heavily on agrarian men. The increasing depredations of our shipping under British orders-in-council and decrees of the French Directory, the fear that war emergency could be used as the excuse to swell a standing army, launch a large-scale navy, and risk domestic liberty, the difficulty in distinguishing critique from cabal, party from faction, left the constitutional politics of the late 1790's in a state of high alarm, hard for us to recapture. The measured tones of a Hofstadter, the democratic optimism of a Bailyn or Wood ${ }^{303}$ may distract us from the entropic forces of that decade, when little seemed permanently constituted.

In the political dramat that followed Robbins' delivery to the British, both camps sketched constitutional perils. The first concerned the place of Executive power. The hazard seen by Jeffersonians may remind us that more classical visions of government were not yet out of mind; in Adams' lexicon constitutional monarchy deserved the mantle of Republicanism as much as did any government of direct election; if the path of American political thought had seemed so clear to participants as a Gordon Wood would have it, we might expect less anxiety at Adams' views. The violent excesses of popularity in the decade seemed only to corroborate Adams' argument that some third counterweight must keep peace between ordinary and advantaged men. Pacificus staked that the American Executive could not be limited to enumerated powers; governance was more than a menial's application of legislative rules; the constitutional oath was to execute the Office of President. ${ }^{304}$ The lifetime

303. See R. HOFSTADTER, THE IDEA OF A PARTY SYSTEM: THE RISE OF LEGITMATE OPPOSITION IN THE UNITED STATES, 1780-1840 (1969); B. BAILYN, General Introduction: The Transforming Radicalism of the American Revolution, in PAMPHLETS OF THE AMERICAN REVOLUTION 1750-1776 (1965); G. WOOD, The Relevance and Irrelevance of John Adams, in THE CREATION OF THE AMERICAN REPUBLIC, 1776-1787, at 567.92 (1969).

304. For Hamilton, Article II's enumeration of powers served rather to limit which Executive powers were shared with the Senate, i.e., the appointments process and treaty-making. For a High Federalist, the injunction that the President "shall take Care that the Laws be faithfully executed," need not be read as a description of the President's compass to act, but only as clarifying that the American Executive cannot 
monarch proposed at Philadelphia, however fleetingly, was cited in Republican papers as proof of High Federalists' larger designs. ${ }^{305}$ The reprinting of John Adams' Defence of the Constitutions of Government of the United States of America by Federalist publisher William Cobbett in 1797 may have seemed a deliberate tack to estop the President with his own unguarded words. ${ }^{306}$ Certainly it allowed the Republicans much play. Though the Defence was written before Annapolis or Philadelphia, in response to an essay by Turgot praising unicameral government, ${ }^{307}$ the proximity of its timing to the work at Philadelphia allowed Republicans to present it as Adams' gloss on the future of the new American Constitution; the Defence seemed to place each of his later executive acts into a larger design.

With a textual Constitution that does not address the interplay of the Senate's treaty power and the Congress' legislative power, one could imagine a Very High Federalist reading: treaties can arrange any subject matter deemed appropriate by the President and Senate; treaties can be signed and approved in secret session with no submission to the opinion of citizens or the scrutiny of the press; treaties can be enforced directly by the President even without House implementation; the President can call upon federal courts for assistance through a self-executing reading of Article III or through court jurisdiction created by treaty; the President can charge judges to act as treaty commissioners against citizens' liberty and property wholly outside the aegis of Article III; and to top it all, treaties could be a paramount form of law, immune from interference by legislation. ${ }^{308} \mathrm{~A}$ headstrong or self-possessed Executive might act even without a treaty: the unwritten law of nations could create a binding

suspend statutory law. (James II's example, offering dispensation to Catholic subjects from Parliamentary restrictions, was still in recent mind.) Faithful execution did not entail that a President have no decretal powers in the face of Congressional inaction. Legislation was for matters that admitted regularity; executive decision was the residual safeguard for the flux of foreign policy and its domestic implementation. Cf. C. MCILIVAIN, CONSTITUTIONALISM, ANCIENT AND MODERN (1940 \& reprint 1983) (governance distinct from legislative power, gubernaculum from jurisdictio).

305. The Hamilton plan offered at Philadelphia was reprinted in the Aurora, "unmask[ing] the political character of the man who has been most instrumental in entailing on the United States those pernicious systems under which they now groan." Aurora (Philadelphia, Pa), Jan. 13, 1798, at 3, col. 2; see also id., Feb. 25, 1799, at 2-3 (reporting Hamilton's plan with a warning of "the danger which our peace and liberties are placed in. ... [T]he period is at hand when it will be determined whether we are to remain a peaceful, commercial and virtuous republic-or become the satellites of the most stern and savage despotism.").

306. 1 J. ADAMS, A DEFENCE OF THE CONSTTIUTIONS OF GOVERNMENT OF THE UNTTED STATES OF AMERICA 70-71 (London 1787; Philadelphia William Cobbett publ. 1797) ("the English constitution is, in theory, the most stupendous fabrick of human invention . . . . The Americans have not indeed imitated it in giving a negative, upon their legislature to the executive . . . very much I confess to my mortification"); id. at 208 ("The constitution of England is in truth a republic"); id. at 371 ("Let the people take care of the balance . . . the instant the [nobility and monarchy] are destroyed, their own branch, their own deputies, become their tyrants."). Adams' elective monarch would be "high priest, high admiral, and generalismo," complained the Richmond Examiner. "An executive with such authority can and ever does turn the beam as he wishes." Examiner (Richmond, Va.), in Aurora (Philadelphia, Pa.), Nov. 8, 1799, at 3, col. 1.

307. See 1 J. ADAMS, supra note 306 , at 3-4.

308. For the suggestions by John Jay and Alexander Hamilton that treaties could not be superseded by later statutes, see stupra note 78 . 
obligation to another country and faithful execution of "the law" might allow a President to arrange domestic affairs to carry out the obligation.

For Republican alarm, there was the perfect symmetry of the disputed Crown prerogative of impressment and American Executive power. Impressment stood on uneven footing in English law; the king's claim of power to take measures necessary for the safety and survival of the kingdom no longer quelled English critics. ${ }^{309}$ Charging John Adams with indifference to a sailor's impressment fitted the Republican view that Adams approved the English Tory's reserve of powers to the Crown and wished to outfit the Presidency with the same range. In a post-Glorious age, an American could not appeal openly to prerogative and expect to convince, but treaty power stood as a pronounceable method to enlarge Executive license. The Federalists' use of treaty power held the additional irony of calling a financial end to the Revolution, settling its remaining claims, through the organs of American government least democratic. Treaty power seemed a dangerously facile instrument for a counterrevolutionary league of princes with their privy councillors.

In this setting, confinement of the President's power to execute the law was a most urgent Republican task. One tack was to obtain Congressional control of federal court jurisdiction, so that the Executive could not call independently upon judges to enforce its treaties-nor ask judges to side-step Congress and act upon the Executive's will or upon unwritten law in the guise of common law, the law of nations, or inherent Article II powers. Hence a demand that technical statutory requirements of jurisdiction always be met, to test whether the judge is acting in accord with Congressionally allocated competence..$^{310}$

Treaty power should be cabined; limiting the President to the execution of law gave little comfort so long as he could make any desired law in concert with an aristocratic Senate and a foreign prince. If the subject matter proper to treaties could not be easily confined, as Senator Bricker would find in our

309. See 1 W. BLACKSTONE, COMMENTARIES ON THE LAWS OF ENGLAND 406 (1st Eng. ed. Oxford 1765) ("The power of impressing men for the sea service by the king's commission, has been a matter of some dispute, and submitted to with great reluctance . . . no statute has expressly declared this power to be in the crown, though many of them very strongly imply it."); AN ENQUIRY INTO THE NATURE AND LEGALITY OF PRESS WARRANTS 31 (London 1770) (available in British Museum) ("IO]ur personal security is grafted on the firm basis of law and nothing less than an act of the legislature can diminish or impair it."); 1 W. BLACKSTONE, COMMENTARIES ON THE LAWS OF ENGLAND 419 (5th Eng. ed. Oxford 1773) ("power of impressing seafaring men for the sea service") (emphasis added); J. MACKENZE, CONSIDERATIONS ON THE IMPRESS SERVICE (1786), available in THE MANNING OF THE ROYAL NAVY, SELECTED PUBLIC PAMPHLETS 1693-1873, at 124, 129 (J. Bromley ed. 1974) ("If [the impress] was really constitutional, why has not an absolute sanction been given to it by an express act of the legislature for that purpose? The circumstance is a tacit confession that it is not so.") (emphasis added); J. CHITTY, A TREATISE ON THE LAW OF THE PREROGATIVES OF THE CROWN 47 (London 1820) (prerogative of impressing seafaring men "has been much attacked, and is certainly a blot on English freedom, [but] is founded on immemorial usage, recognized, admitted, and sanctioned by various Acts of Parliament").

310. In this we may see the troping brilliance of Marbury once again-Marshall's statement that the Court would be scrupulous concerning jurisdiction, albeit resisting an expanded Congressional assignment rather than Executive. 
century, ${ }^{311}$ still a presumption against "self-execution" of treaties in areas of domestic legislature might suffice, requiring the ratifying voice of the House before a treaty could be acted upon to limit domestic entitlements of liberty or property. A third tack was to create costly political disincentives, in that merging of constitutional law and politics which Justice Jackson was to recognize in the Steel Seizure case. ${ }^{312}$ Any President who claimed the right to act upon domestic enjoyments against the wish of the people's more numerous elected representatives would be put through the wringer, run through the gauntlet, oxidized in an auto-da-fé, unless the emergency impelling his action was so evident that popularity must follow.

Another anxiety concerned the independence of the Judiciary. Crown influence in Parliament through pensions and sinecures raised concern the American judiciary could be tempted to hold parallel enriching office. There was the sense that a monocratic President could easily overawe a local federal judge, or could tempt him to act out of doors in an uncertain capacity, meanwhile to forget his sacramental duties as keeper of habeas corpus. The openly partisan activities of some Federalist judges and justices, whose grand jury addresses veered toward stump speeches, left little reason to suppose the judiciary would resist a Federalist Presidency. Hence a demand that federal judges be forbidden by law to hold any parallel governmental office. Hence a demand that the President renounce any general power to determine issues of law, and eschew any broad version of a "political question" doctrine. Hence a demand that the Executive never purport to direct or even "advise and request" a federal judge to take particular action. And, surpassing all, a demand that the jury must retain its central role in all matters of liberty; the "country" could resist where a judge would not.

But the metonymic sparkle of Jonathan Robbins did not depend only on the occasion for constitutional address. The mutiny allowed Republicans to recall revolutionary virtue. Constituted authority was not due any form of passive obedience from citizens of the New Republic; the right of resistance was not alienable. Robbins had only retributed the past humiliations of William Jessup and other American sailors. Federalist servility, suffering the British to continue impressment, reaching commercial accommodation despite British naval condescension, was proof that the War for Independence was not complete. Halfsovereignty and leonine treaties were to be expected in an Anglophile administration; the monocrat Adams would not insist on due regard for the divorce. Federalists were Loyalists; and Republicans could wear the mantle of Patriot. The true facts of the Robbins affair-that probably he was not American-did not spoil the story; a closely examined record was not the point; the story was too compelling; and in any event the Irish subjects of Britain could make the

311. See D. TANANBAUM, THE BRICKER AMENDMENT CONTROVERSY (1988).

312. Youngstown Sheet \& Tube Co. v. Sawyer, 343 U.S. 579, 634 (1952) (Jackson, J., concurring). 
same claims of "liberticide." If Robbins was not impressed, still Pigot was a tyrant; a Republican ship need not be run with the bloody inducements of a British frigate. ${ }^{313}$

Robbins served Republican fiction as Charles Darnay would serve the English. The world had seen how the French consumed their young in random besotted violence; democracy looked unattractive if its natural extension was popular passionate tribunals, sacrificing the unassuming and unrehearsed. But the figure hung in chains from a gibbet, for all passing mariners to see, permitted the thought that Terror could come from many quarters, including sober established British tribunals whose transcripts were kept in an elegant hand. It was a timely tale. Robbins gave Republicans a sacrificial figure of innocence at a season in mid-1799 when High Federalists were demanding war against France. The Directory's provocation to American pride in the XYZ affair had unfolded the previous year; without an equally personalized insult from the British, the war cry seeking Anglo-American alliance against France would have been harder yet to contain. ${ }^{314}$

Robbins' transfiguration also came at a time of want. Washington was the first exemplar of political and martial virtue, but was he not now appropriated to Federalist causes? ${ }^{315}$ Declining to join the French in their revolutionary tide, marching against Whiskey Rebels, defending the Jay Treaty, reassuming military command in 1798 in warning to the Directory, was he not also a figure of aristocratic mien? Robbins was the uncelebrated man in the ranks, newly revealed by the levée en masse as the source of a nation's power. And if men's common nature left them unworthy to govern by High Federalist view, Robbins' sacrifice showed the redemptive force of liberty. Even Robbins' silence at the court-martial, his mute disinclination to offer a defense, and his warning at execution that other sailors should avoid his actions, might suit a tale of virtue's visitation.

Robbins' violence was warning against Federalist hauteur. Mechanics, farmers, and sailors had claim to a New World dignity, and any master, Federalist or British, must respect their person. The marines on board the Hermione

313. Robbins' fate on the tide-borne vessel could recall another memory of the British: the notorious prison ships of the Revolution, "where pain and penance dwell / Where death in tenfold vengeance holds his reign, / And injur'd ghosts, yet unaveng'd, complain; / . . ungenerous Britons, you / Conspire to murder whom you can't subdue." PHLIP FrENEAU, The British Prison Ship (1780), in POEMS ON SEVERAL OCCASIONS, supra note 302 , at $161,166$.

314. Adams' British connection in Robbins helped to insulate him from the High Federalist charge that his overtures of peace to the French were unbalanced. Adams decided in early 1799 to send additional envoys to the Directory; Senate confirmation of the envoys was obtained in late 1799.

315. "It is as well the ingratitude as the pusillanimity of Mr. Washington and the Washington faction, that has brought upon America the loss of character she now suffers in the world," complained Thomas Paine after the Neutrality Proclamation and Jay Treaty. THOMAS PAINE, LETTER TO THE LATE GENERAL George Washington When President of THE UnITEd States 33 (Paris 1795, Philadelphia Benjamin Bache publ. 1796, Baltimore 1797, and New York 1802), available in EARLY AMERICAN IMPRINTS 16391800, supra note 116 (Evans No. 30951). 
were no shield against a rebellious crew, and in domestic government, too, no standing ar:ny nor nervous measure of penal law could counter withdrawal of consent to be governed. Robbins reminded that Republican opposition could not be extinguished by decree.

The case took dead aim at any accrual of extraordinary powers to the Executive, including John Adams' new statutory power to exclude any alien he thought posed a hazard to American security. ${ }^{316}$ Robbins invited the suggestion that Adams might wish to extend the arbitrary powers of expulsion from aliens to citizens. It was not easy to tell alien from citizen, Robbins seemed to show; couldn't an Executive choose to ignore an uncorroborated claim of American citizenship and force a native critic out of the country? Nor should the distinction of alien and citizen be so stark. True citizenship consisted of devotion to common republican principles, as philosophical landsmen; accidental place of birth or past oaths of allegiance should not overshadow shared conviction. ${ }^{317}$ English pressing challenged American identity, in the claim there was nothing distinctive to signal a North American son. But the mark of a son of liberty was his willingness to rebel. ${ }^{318}$ The very ambiguity of Robbins' citizenship invited the view of a broader republicanism. Even the martial engagement of the Irish against the Crown might be seen as an adoptive American struggle, as if, per later Mormon suggestion, America was responsible for the salvation not only of its own citizens, but of all from whom they descended.

The mutiny allowed Republicans to suggest that America was obliged to reform the law of nations, to propose international maritime rules more respectful of territorial independence and commitment to liberty. Republicans quarreled with the Federalist tenet that a belligerent could search the vessel of a neutral for contraband; even without special treaty provisions belligerents should be required to accept the neutral's avowal of the contents and ownership of the cargo, based on national honor and evidenced by passport and lading bills. To be sure, enforcement of this claim would have required a sizable navy, favored

316. See An Act concerning Aliens, § 1, 1 Stat. 570, 571 (June 25, 1798).

317. $C f$. J. HECTOR ST. JOHN CREVECOEUR, What is an American, in LETTERS FROM AN AMERICAN FARMER 47, 60 (Philadelphia 1793) ("The American is a new man, who acts upon new principles." "We know, properly speaking, no strangers; this is every person's country.").

318. The linking of resistance in Ireland and America was indulged not only by Republican voices. It also encompassed High Federalist fears. During the 1798 uprising in Ireland, Cobbett supposed that the "restless rebellious tribe" of United Irishmen, lately formed into an American chapter, might be conspiring with "free negroes" and naturalized sans-culottes to aid the French in the event of war between France and America. Cobbett pointed with alarm to the test oath of the American Society of United Irishmen: an initiate pledged "the attainment of LIBERTY and EQUALTY, TO MANKIND, IN WHATEVER NATION I MAY RESIDE." See Detection of a Conspiracy, Formed by the United Irishmen, for the Evident Purpose of Aiding the Views of France in Subverting the Government of the United States of America, Porcupine's Gazette (Philadelphia, Pa.), May 8, 1798, at 2, cols. 1 \& 3 (emphasis in original). On the fear of French attack, see also A LETTER FROM ROBERT GOODLOE HARPER OF SOUTH CAROLINA, TO ONE OF HIS CONSTITUENTS, supra note 212, at 20 (August 1798) ("That [France] will attempt to invade us, unless her affairs in Europe keep her too fully employed, I think highly probable."). 
by Adams but opposed by Republicans. This practical contradiction did not keep Republican critics from arguing that the principle of armed neutrality, with free bottoms making free goods, exempt from British stop-and-frisk, would avoid so many of the occasions when American sailors were spirited ayay. Over the next two decades, the Aurora reprinted tracts on the law of nations favoring armed neutrality and mocking rules of belligerency and neutrality that, in Republican eyes, had been dictated by the British and supinely endorsed by Hamiltonians. ${ }^{319}$

So too, in Republican eyes, the Federalists acquiesced in a theory of perpetual allegiance that allowed Britain to justify its practice of impressment. A British sailor remained a Crown subject, no matter his new oath of allegiance and connection to America. The pledged loyalty of naturalized emigrants was not sufficient to induce respect from America's British sibling, as if the United States lacked full dominion. ${ }^{320}$ For a country that depended upon emigration to fill out its populace, perpetual allegiance was an irksome theory. Yet Federalists used the same theory of perpetual allegiance to prevent American mariners from adopting "citizenships of convenience" in privateering, and in doing so, seemed to give comfort to British pretension: no American was truly free of the Crown. ${ }^{321}$ Pace Albert Hirschman, denying a right of exit also seemed

319. "[B]ecause her marine has been generally predominant" complained Aurora publisher William Duane, "[Britain] asserts a right of giving law to all commercial states." W. DUANE, THE LAW OF NATIONS INVESTIGATED IN A POPULAR MANNER ADDRESSED TO THE FARMERS OF THE UNITED STATES 98 (Philadelphia 1809). In advocacy of a law of nations more suited to small commercial countries, Duane republished the work of Danish jurist J.F.W. Schlegel, NEUTRAL RIGHTS; OR, AN IMPARTIAL EXAMINATION OF THE RIGHT OF SEARCh OF NeUTRAL Vessels UNDER CONVOY (Aurora, Philadelphia 1801). See also C. PINCKNEY, THREE LETTERS, WRTTEN, AND ORIGINALLY PUBLISHED, UNDER THE SIGNATURE OF A SOUTH CAROLINA PLANTER 21-36 (Aurora, Philadelphia 1799) (Letter II, On the Recent Captures of American Vessels by British Cruisers, Contrary to the Laws of Nations, and the Treaty Between the Two Countries).

320. Impressment also demanded that British military need should take precedence over international comity. Prizes were taken to port, for a hearing by an uninvolved judge, but in impressment a summary British decision interposed itself by force. The only remedy for wrongful impressment was to raise a diplomatic protest with the British minister, or to allow intervention by the American consul when leave from a ship was granted in a port of call.

321. Chief Justice Oliver Ellsworth, sitting as a Circuit Justice in the Hartford case of Isaac Williams in September 1799, seemed to suggest that in naturalizing an emigrant the United States did not undertake to defend him against claims that he owed a prior allegiance, and hence, against foreign claims for his military service. See United States v. Williams, 29 F. Cas. 1330 (C.C.D. Conn. 1799) (No. 17,708). Isaac Williams, a New London man, had accepted a commission as an officer in the French navy, renouncing his American citizenship, and taking part in the capture of British prize vessels. On the indictment for violating Article 21 of the Jay Treaty, Chief Justice Ellsworth declined to allow the jury to hear Williams' defense of expatriation, that he had renounced his American allegiance and any duty to abide by American neutrality. Williams tried to argue from symmetry: Individuals must have a right to change their allegiance, since the United States willingly accepts emigrants as new citizens. Ellsworth's words of rejection seemed to give undue comfort to British press gangs: "When a foreigner presents himself here," and is otherwise qualified, "we grant him the privilege of a citizen. We do not inquire what his relation is to his own country; we have not the means of knowing, and the inquiry would be indelicate; we leave him to judge of that. If he embarrasses himself by contracting contradictory obligations the fault and the folly are his own." Id. at 1331 . 
a portent for denying a right of revolution; an individual's withdrawal of consent did not release him from national duties. ${ }^{322}$

Impressment's gall and burr would disquiet American-British relations for the next forty years. The issue yielded the $1812 \mathrm{War}$, and in turn the Hartford Convention whose hints of disunion are often credited with ending the Federalist party, later still, creating serious worries of war from 1837 to 1842 . The iconography of Robbins, Pigot, Pickering, and Adams was kept fresh in public mind.

The rhetoric accompanying the Robbins case now sounds almost camp, with a sentimentality and self-congratulation that dissuade. But we mistake its effect unless we place it in a situation of military and political insecurity, with clumsiness taken for sincerity, as obvious and charged as a soundbite. The cult of martyrs of liberty, noted in other revolutions, had its counterpart here, Nathan Hale's countryman whose death would inspire resistance. ${ }^{323}$ The participants of the Whiskey Rebellion had been pardoned by Washington after a few prosecutions; ${ }^{324}$ Fries' rebels were pardoned by Adams in the spring of 1800 in attempted reconciliation. ${ }^{325}$ But Robbins was the perfect Republican figure, since a pardon could not retrieve him. John Fenno, the High Federalist editor of the Gazette of the United States, hoping to mock Popishness, French radicalism and the most virulent Republican critic, despaired of "St. Jonathan Robbins [who] ranks as the first martyr in the democratic callendar."326

The immediate Republican attack after the Robbins execution came in three waves: the 1799 state and local elections, in which placards of Jonathan Robbins and tendentious poetry were displayed at every parade ground; the 1800 Congress in which Edward Livingston and Albert Gallatin toyed with the censure or impeachment of Adams; and the 1800 Presidential election. The cascading criticisms of Adams, Pickering, and Bee, of the "unseen hand" of the British in American councils, touched on all the substantive grounds before

322. Cf. A. HIRSCHMAN, EXIT, VOICE, AND LOYALTY (1970).

323. To be sure, the evident cruelty of a hanging and gibbeting may sign for both sides. Mock hangings of political opponents at Liberty Trees rallied popular zeal in revolutionary America; Robbins in chains turned the figure round in counter-revolutionary waming. Yet for resistants, Robbins' limp body could summon other memory of Christian Freedom and hale individual courage. See generally P. SHAW, AMERICAN PATRIOTS AND THE RITUALS OF REVOLUTION 180-84 (1981); MONA OZOUF, FESTIVALS AND THE FRENCH REVOLUTION (1988). On figures of sacrifice, see R. GIRARD, VIOLENCE AND THE SACRED (1977) (awe of violence imparts sacredness to victim); E. DURKHEM, THE ELEMENTARY FORMS OF THE RELIGIOUS LIFE 388-89 (1915 \& reprint 1965) ("The things which the worshipper really gives his gods are not the foods he places upon the altars, nor the blood which he lets flow from his veins: it is his thought." In reality, "the effect of the cult . . . is to recreate periodically a moral being upon which we depend as it depends upon us. Now this being does exist: it is society." Or, we might add for Durkheim, it is the revolution.).

324. See Proclamation of July 10, 1795, in 34 THE WRITINGS OF GEORGE WASHINGTON, supra note 95, at 232-34 (general amnesty for those not yet indicted); $35 \mathrm{id}$. at $417 \mathrm{n.48}$ (pardon of those convicted).

325. See Proclamation of May 23, 1800, in Aurora (Philadelphia, Pa.), May 24, 1800, at 2, col. 2 (general pardon). Fries and his co-defendants were individually pardoned. See Letter from John Adams to Charles Lee (May 21, 1800), in 9 THE WORKS OF JOHN ADAMS, supra note 193, at 60-61.

326. Gazette of the United States (Philadelphia, Pa.), Nov. 19, 1799, at 2, col. 2. 
adverted. The main constitutional foci were: constraining the Executive's attempt to implement treaties without further ratification by the House, reinforcing the legislative limits on federal court jurisdiction and maintaining judicial independence in treaty interpretation, and interposing a greater role for the jury or grand jury.

These constitutional readings might slow the return of foreign criminals, but Republicans could take comfort from Jefferson's private view favoring American legal isolation, at least in criminal matters. Years before Robbins, Jefferson had sketched a position, while serving as Secretary of State in 1792, that proposed separation of the American legal system from others in criminal law. "Reformation of government with our neighbors, [is] as much wanting now as Reformation of religion is or ever was anywhere," Jefferson had explained, counseling Washington against entering into any arrangement with the Spanish for the retrieval of criminal fugitives. ${ }^{327}$ The religious virtue of the shining city on the hill was revived in American political virtue, and, as once thought in matters of the religious heart, separation was the only course. For theft or debt, a fugitive's exile should be a sufficient punishment. Treason was a terrible act "when real, [and] merits the highest punishment," but most nations' codes "do not distinguish between acts against the government, and acts against the oppressions of the Government." 328 Hence, murder should never be the cause for return of a fugitive, unless it was murder "of malice prepense, and not of the nature of Treason." 329 Piracy could be punished through the use of universal jurisdiction in the country of asylum. And always, in Jefferson's early view, delivery should be made only if a grand jury returned a true bill of approval. ${ }^{330}$ The exchange of criminals was "so difficult between a free and an arbitrary government." 331

327. T. Jefferson, Heads of consideration on the establishment of Conventions between the United States and their neighbors for the mutual delivery of Fugitives from Justice (Mar. 22, 1792) (emphasis omitted), in 23 THE PAPERS OF THOMAS JEFFERSON, supra note 146, at 328, 329 (C. Cullen ed. 1990); see Letter from Thomas Jefferson to George Washington (Nov. 7, 1791), in 22 THE PAPERS OF THOMAS JEFFERSON, supra note 146, at 266.

A request by Republican Governor Charles Pinckney of South Carolina to President Washington to seek the return of two forgery defendants from Spanish authorities in St. Augustine, Florida, and the pending negotiation of a treaty of navigation and amity with the Spanish, gave rise to Jefferson's sketch. Washington referred Charles Pinckney's request to Jefferson, who, as his wont, tried out his views on Madison. See 23 The PAPERs of ThOMAS JefFerson, supra note 146 , at 286, 360, 469; 31 THE WRITINGS OF GEORGE WASHNGTON, supra note 95, at 412. In the treaty ultimately reached with Spain in 1795 by Governor Charles Pinckney's cousin, Thomas Pinckney, there was no provision for delivery of fugitive criminals. See Treaty of Friendship, Limits, and Navigation, signed Oct. 27, 1795, United States-Spain, 8 Stat. 138, T.S. No. 325.

328. T. Jefferson, Heads of consideration on the establishment of Conventions between the United States and their neighbors for the mutual delivery of Fugitives from Justice (Mar. 22, 1792) (emphasis in original), in 23 THE PAPERS OF THOMAS JEFFERSON, supra note 146, at 329.

329. Id. at 329 (emphasis in original).

330. Id. at 330.

33I. Letter from Thomas Jefferson to James Madison (Mar. 16, 1792), in 23 THE PAPERS OF THOMAS JEFFERSON, supra note 146, at 286. 
Jefferson's own practice was inconsistent with this theory, to be sure. An undertaking of his earlier career had created an asymmetry which the Jay Treaty partially cured. In 1788, as American Minister to France, Jefferson completed an arrangement for the arrest and return of French maritime deserters found in American ports. Ratified in 1790 , this was the first treaty undertaken with any European power under the new Constitution. ${ }^{332}$ An extraterritorial jurisdiction for French consuls was permissible, Jefferson allowed in a spirit of commercial Republicanism, because "The power of arresting deserted seamen seems necessary for the purposes of navigation and commerce, and will be more attentively and effectually exercised by the Consul than the territorial judge." 333 Throughout the last years of the 1790's, the British continued to argue that a parallel arrangement for the return of English naval deserters hiding in American merchant service would minimize the occasions for high seas searches and mistaken impressment of Americans. ${ }^{334}$ The Adams administration declined to replicate the consular treaty with the British, because of Britain's unwillingness to abandon impressment, but Pickering's reading of the Jay Treaty allowed recapture of the most violent deserters. Republicans would be able to put the 1790 French consular agreement to some use in procedural attack, for the French deserters article was not invoked in practice until after Congressional passage of implementing legislation, ${ }^{335}$ and evidentiary requirements under the treaty were rigorously enforced by the judiciary. ${ }^{336}$

332. See Article 9, Convention between His Most Christian Majesty and the United States of America, for the Purpose of Defining and Establishing the Functions and Privileges of Their Respective Consuls and Vice Consuls, United States-France, 8 Stat. 106, 112, T.S. No. 84 (signed Nov. 14, 1788; proclaimed Apr. 9, 1790):

The consuls and vice-consuls may cause to be arrested the captains, officers, mariners, sailors, and all other persons, being part of the crews of the vessels of their respective nations, who shall have deserted from the said vessels, in order to send them back and transport them out of the country: For which purpose, the said consuls and vice-consuls shall . . . demand the said deserters in writing, proving by an exhibition of the registers of the vessel or ship's roll, that those men were part of the said crews; and on this demand so proved (saving however where the contrary is proved) the delivery shall not be refused.

There were earlier agreements with Indian nations.

333. Letter from Thomas Jefferson to Count Mortmain (June 20,1788), in 14 THE PAPERS OF THOMAS JEFFERSON, supra note 146 , at 123.

334. See Instructions of Grenville to Liston (July 5, 1797; Jan. 9, 1798; Mar. 23, 1799), in INSTRUCTIONS TO THE BRITISH MINISTERS TO THE UNITED STATES 1791-1812, supra note 9, at 135, 144, 172; Letters of Charles Lee to John Adams (Feb. 26, 1800), Secretary of Treasury Oliver Wolcott to John Adams (Apr. 14, 1800), Secretary of War James McHenry to John Adams (Apr. 18, 1800), Secretary of Navy Benjamin Stoddert to John Adams (Apr. 23, 1800), in 3 DOCUMENTS, 'LEGISLATIVE AND EXECUTIVE OF THE CONGRESS OF THE UNITED STATES [AMERICAN STATE PAPERS, FOREIGN RELATIONS] 578-81 (W. Lowrie \& M. Clarke eds. 1832).

335. An Act concerning Consuls and Vice-Consuls, $\S 1,1$ Stat. 254 (Apr. 14, 1792).

336. In 1795, the French consul in New York sought the arrest of the French Republic's Captain Barre, commander of the frigate Le Perdrix, who had "voluntarily abandoned his ship, and became a resident in New York" after bringing a convoy to the American coast. A warrant of arrest was refused by Judge John Lawrence of the District of New York because the original of the ship's register was not available as proof as required by the treaty. Attorney General Edmund Randolph sought mandamus, unsuccessfully, to overcome this evidentiary scruple. See United States v. Lawrence, 3 U.S. (3 Dall.) 42 (1795). 
Political attention to the Robbins affair, directed toward the 1799 elections, began within days of Judge Bee's delivery to the British. South Carolina newspaper reportage was initially mild. The Charleston City Gazette and Daily Advertiser, published by Peter Freneau and Seth Paine, of moderate Republican sympathy, ${ }^{337}$ did not run the story immediately, in one issue promising future publication of the arguments of counsel on an "interesting question,"338 in the next postponing the coverage in favor of "late European news,"339 and finally printing the court proceedings on July $31,{ }^{340}$ with an editorial apology the next day "indulg[ing] the hope, that the public will believe they had no motive in giving publicity to the case of Robbins ... than a conviction that it was a case ... of sufficient importance to be generally made known." ${ }^{341}$

Newspapers in the capital, however, picked up the scent almost immediately. ${ }^{342}$ On August 6, the Aurora, founded by Benjamin Franklin's grandson Benjamin Franklin Bache and continued by his widow Margaret Bache with writer William Duane, ${ }^{343}$ interrupted a series on "British Influence" to take note of Judge Bee's decision, ${ }^{344}$ running a full transcript six days later. Despite the American pretense of neutrality between the English monarchy and French republic, "a letter is said to have been produced from the administration of the American government-'ADVISING AND REQUESTING' that an impressed citizen should be delivered up to the foreign belligerent power."345 The "unexampled facts" of the "extraordinary proceeding" showed that a "doctrine was held and a decision made thereupon, that A TREATY made by an AGENT of the PEOPLE was PARAMOUNT to the CONSTITUTION under which the agent was chosen." The Aurora summoned its bowmen with these words:

These are alarming facts, and if they are authorised by any principle of our constitution, then are we no longer an independent people, but subjects of a tyranny the extent of which is not to be limited; for if one treaty may be made paramount to the constitution - another may be made with Great Britain, and Russia, Turkey, and Austria, ${ }^{346}$ to anni-

337. Charleston publisher Peter Freneau, younger brother of Philip Freneau, would become Jefferson's campaign manager for South Carolina in 1800 , but his Charleston newspaper kept a more catholic view than the unyielding efforts of Bache, Callender, Cooper, or brother Philip.

338. The City Gazette and Daily Advertiser (Charleston, S.C.), July 27, 1799, at 3, col. 1.

339. Id., July 30,1799 , at 3 , col. 1 .

340. Id., July 31, 1799, at 1-3; see also Carolina Gazette (Charleston, S.C.), Aug. 1, 1799, at 2-3.

341. The City Gazette and Daily Advertiser (Charleston, S.C.), Aug. 1, 1799, at 3, col. 1.

342. News could sail from Charleston to Philadelphia by seven day schooner.

343. After Benjamin Franklin Bache died of yellow fever on September 10, 1798, Margaret Bache carried on publication of the Aurora with Duane, in rhetoric of equal pugnacity. Duane took the title of publisher shortly before his marriage to Mrs. Bache in 1800.

344. Aurora (Philadelphia, Pa.), Aug. 6, 1799, at 3, col. 2; see also Gazette of the United States (Philadelphia, Pa.), Aug. 2, 1799, at 3, col. 3.

345. Aurora (Philadelphia, Pa), Aug. 12, 1799, at 2, col. 1 (emphasis in original).

346. These were the members of the counter-revolutionary Second Coalition mobilized against Napoleon. 
hilate our form of government, and if a President and Senate could be found to ratify it, we should therefore be bound to submit. . . . BRITISH INFLUENCE threatens destruction to these States! $!^{347}$

The same rhetoric continued fortissimo throughout August 1799; Robbins was delivered up to "the fangs of ... tyrants," 348 to "a merciless banditti"; 349 "[w] hat was the case of Robbins yesterday, may be YouRs to-morrow."350 In a column endorsing Republican Thomas McKean for Pennsylvania Governor, "An American" noted Robbins' delivery as "a specimen of what we may expect from appointing men to fill the first stations in our general and state governments, who are acting under the immediate influence of the government of Great Britain." ${ }^{351}$ Federalist checks and balances were "Yankee Checks," the Aurora had earlier instructed, unifying all power in the Presidency, constraining only the legislature. ${ }^{352}$ Federalists "wish[ed] . . . a government in which the Executive should be more than a match for the people," ${ }^{353}$ and Robbins was proof of a British pudding. "[S]pirits of seventy-six[,] said I[,] whither are ye flown!" asked the pseudonymous Robert Slender, pen name of Philip Freneau; "we must be once more a British colony." 354 Some alphabetical humor on Executive pretension was offered by a Maryland correspondent named VERITAS: "every little prattling child knows that A is the beginning of the alphabet, therefore $B$ is certainly inferior, and directly under the influence of A. Now as A is the first in order, I would make him something great, as a king for instance." 355 In electoral drollery, an "American Sailor" offered that he had "hauled up my courses, and laid my maintopsail aback, nor will I ever sail away again until government gives our class of citizens an explanation." ${ }^{356}$ Might a mate of John Paul Jones be demanded for extradition under the treaty, "for having murdered some of the crew of his majesty's ship the Serapis when she was captured by the Bon Homme Richard"? ${ }^{357}$ The officers of the Hermione were killed as "victims of that just spirit of revenge which their tyranny had raised." If Robbins was given up, "what becomes of the natural, not to mention the political rights of an American citizen?"358

347. Aurora (Philadelphia, Pa), Aug. 12, 1799, at 2, col. 1 (footnote added \& paragraphing omitted) (emphasis in original).

348. Id., Aug. 13, 1799, at 2, col. 2.

349. Id., Aug. 16, 1799, at 2, col. 4 .

350. Id., Aug. 13, 1799, at 2, col. 2 (emphasis in original).

351. Id., Aug. 16, 1799, at 2, col. 4 .

352. Id., Jan. 24,1798 , at 3, col. 4 .

353. Id., Mar. 8, 1799, at 3, col. 2.

354. Id., Aug. 24, 1799, at 3, cols. 3 \& 2; see POLITICAL WORKS OF CONCEALED AUTHORSHIP RELATING TO THE UNITED STATES 1789-1810, at 93 (P. Gaines ed. 1972).

355. Aurora (Philadelphia, Pa.), Aug. 20, 1799, at 2, col. 2 (emphasis in original).

356. Id., Aug. 20, 1799, at 2, col. 2.

357. Id., Aug. 24, 1799, at 2, col. 2.

358. From the Albany Register, in Aurora (Philadelphia, Pa.), Aug. 17, 1799, at 3, col. 2. 
On September 3, 1799, with the elections closer, "Robert Slender" offered an epitaph for Robbins, pictured in Figure B, lamenting Americans' "humbled and degenerate country." Anti-Federalist grievances-the British treaty, the financial claims feared from the treaty commissioners, the Alien and Sedition Acts, Adams' Stamp Act and Window Tax, the mustering of a standing army-were accompanied by warning of the "scheme for restoring universal slavery ... unfolding too fast by the principal actors in our country . . . British arms could not prevail twenty years ago-they now use other weapons." ${ }^{359}$

The remedy for distressed citizens was demurely pointed out in several letters to the Electors.

Let Porcupine growl, Liston pet, the long list of English agents, speculators, approvers of the fate of Jonathan Robbins, tories and refugees, gnash their teeth in vain, be ye true to your country, proof against bribery, true to posterity, true to yourselves, arrange ye under the banners of freedom, and ONCE MORE conquer, let the word be LIBERTY and M'KEAN. ${ }^{360}$

Three days before the Pennsylvania election, the Aurora obliged by printing news of Robbins' hanging, and sharing with the electorate a "last letter" from "Jonathan Robbins," enclosed by a correspondent who wished to be anonymous so as "not . . . to encounter party rage." Asked Pseudo-Robbins, "would not the most virtuous man, if he had the least spark of American spirit have done the same?" but then began to hedge a bit: "It has been said I am an Irishman, but you know I am an American. [But] [s]uppose I was from that country... should they be press'd, beat and abused, by a set of rascals, and not endeavor to gain their liberty, or when they have done it-be delivered up to be slaughtered!" 361 Three days later, Thomas McKean was elected Pennsylvania Governor, running substantially ahead of Federalist James Ross in the

359. Aurora (Philadelphia, $\mathrm{Pa}$ ), Sept. 3, 1799, at 2, col. 2. Freneau reissued his articles in pamphlet form on December 30, 1799, under the moniker "Robert Slender, O.S.M."-mocking a President who proclaimed days of fasting and prayer during the French peril. Slender's title of noblesse, O.S.M., took aim at Edmund Burke as well. Said Freneau in mock introduction:

[I] cannot come before the public with a flourish, thus- By ROBERT SLENDER, A.M. or D.M.

or LL.D. or F.R.S. . . . [B]ut I can write myself, O.S.M. and that will do quite as well. . . . [I]ts meaning is ONE OF THE SWINISH MULTITUDE . . . I I will dedicate my works to the Freemen, the Lovers of Liberty, the Assenters, Maintainers and Supporters of Independence throughout the United States .... . And if my plain told stories . . can have the effect of calling up the republican spirits to a more ardent love of their country's rights . . . I shall abundantly receive that which I expect....

ROBERT SLENDER, LETTERS ON VARIOUS INTERESTING AND IMPORTANT SUBJECTS iii-vii (Philadelphia 1799 \& reprint 1943) (emphasis in original). See E. BURKE, REFLECTIONS ON THE REVOLUTION IN FRANCE 63 (New York 1791) ("Along with its natural protectors and guardians, learning will be cast into the mire, and trodden down under the hoofs of a swinish multitude.").

360. Aurora (Philadelphia, Pa.), Oct. 2, 1799, at 2, col. 3 (emphasis in original).

361. Id., Oct. 5, 1799, at 2, col. 1 . 
FIGURE B:

Epitaph by Robert Slender (Philip Freneau), in Aurora (Philadelphia, Pa.), Sept. 3, 1799, at 2, col. 1. 


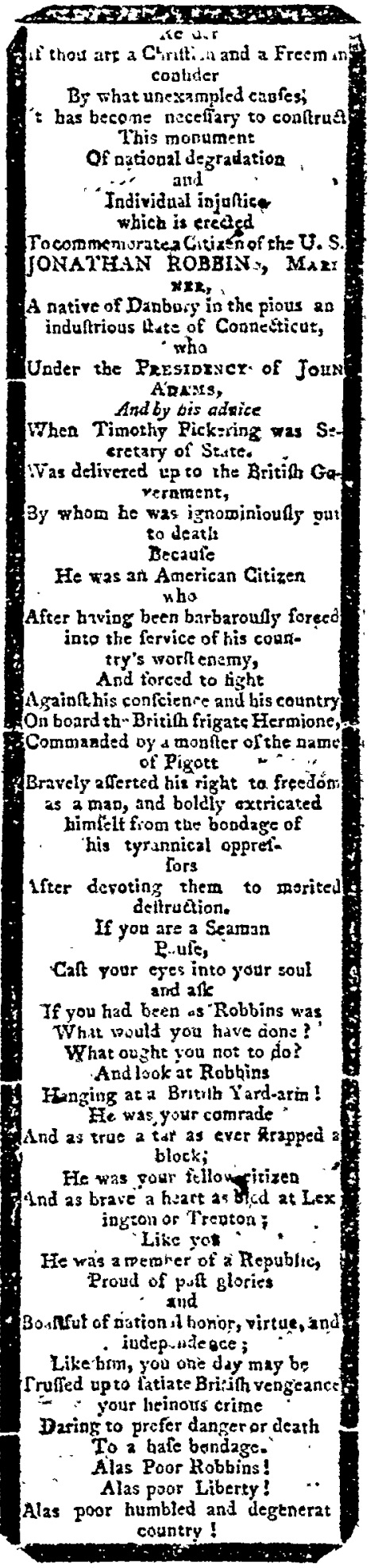


countryside and smaller cities, even while losing the Philadelphia districts (presumably the center of the "old tories, Refugees, Traitors, Aristocrats [and] Monarchists"362 identified by the Aurora as Ross supporters). ${ }^{363}$ Jefferson suggested that Robbins "had a great effect" in the Pennsylvania election. ${ }^{364}$

The election was greeted by fulsome Republican toasts. The Republican citizens of Kensington, Pennsylvania, drank after dinner to McKean, Jefferson, "Reconciliation between the Sister Republics of America and France," and to "The memory of Jonathan Robbins-May the foul stain which our country has received in this man's martyrdom be avenged in the disgrace of those who made him a sacrifice." 365 A song was set to the comic opera tune of "Ballinamona," 366 celebrating "The Republican Triumph," marrying the Federalists to Edmund Burke and recalling Robbins' end:

Ye true sons of freedom, ye rude swinish throng, ${ }^{367}$

Attend for a while, and I'll give you a song.

It's the triumph of freedom, we now celebrate,

A Republican Governor gain'd for the State,

Sing Ballinamona, \&c.

No Governing Tories for me.

$* * * *$

They talked of spoliations committed by France,

Yet were silent when Britain made poor Robbins dance,

But open your eyes sirs and if you have sense,

You will see the spoliations at New Providence, ${ }^{368}$

Sing Ballinamona, \&c.

No unjust distinctions for me. ${ }^{369}$

362. Id., Oct. 8, 1799, at 3, col. 5 .

363. For an overview of the 1799 Pennsylvania election, see H. TINKCOM, THE REPUBLICANS AND FEDERALISTS IN PENNSYLVANIA 1790-1801, at 215-41 (1950).

364. Letter from Thomas Jefferson to Charles Pinckney (Oct. 29, 1799), in 7 THE WRrTwGs of THOMAS JEFFERSON, supra note 18, at 397: "I was both pleased \& edified by the piece on Robbins case. It ought to be a very serious case to the judge. I think no one circumstance since the establishment of our government has affected the popular mind more. I learn that in Pennsylvania it had a great effect."

365. Aurora (Philadelphia, Pa.), Nov. 19, 1799, at 2, col. 2.

366. This was a tune familiar from romantic and martial settings. See HENRY BROOKE, THE SONGS IN JACK THE GYANT QUELLER. AN ANTIQUE HISTORY (Dublin 1749) (Air 22, sung by "Jack Good"); JOHN O'KEEFE, THE POOR SOLDIER. A COMIC OPERA . . A AS PERFORMED, WITH UNIVERSAL APPLAUSE, AT THE THEATRE . . (Philadelphia 1787) (Air 14, sung by Father Luke upon the wedding of Darby and Kathleen), available in EARLY AMERICAN IMPRINTS, 1639-1800, supra note 116 (Evans No. 20606) (also New York 1790, Evans No. 22749; Boston 1794, Evans No. 27445); CALlIOPE, OR THE MUSICAL MisCELLANY 256, 258 (C. Elliot \& T. Kay eds. London 1788).

367. In this porcine phrase, the choristers made light of Burke's REFLECTIONS ON THE REVOLUTION IN FRANCE, see supra note 359.

368. The Bahamian island of New Providence was site of a British admiraity court condemning American vessels as prize booty.

369. Aurora (Philadelphia, Pa.), Nov. 9, 1799, at 3, cols. 1-2 (footnotes added; emphasis in original); also in THE AMERICAN REPUBLICAN HARMONIST; OR, A COLLECTION OF SONGS AND ODES: WRITTEN IN AMERICA, ON AMERICAN SUBJECTS AND PRINCIPLES 27 (Philadelphia, William Duane publ. 1803) (with textual variations), available in AMERICAN ANTIQUARIAN SOCIETY, EARLY AMERICAN IMPRINTS, SECOND SERIES, 1801-1819 (C. Shipton ed. Readex Microprint), indexed as Shaw \& Shoemaker No. 3675, see R. SHAW \& R. SHOEMAKER, AMERICAN BIBLIOGRAPHY (American Antiquarian Society 1958). 
To the future, the Aurora gleamed, "May the republicans ... stand as firm in the election of President as they did for governor. . . . May the republics of France and America be united ... To the memory of Jonathan Robbins who fell a martyr to British tyranny."370

The Federalists' attempts to contain the Robbins affair proved clumsy, falling into Republican snares. William Cobbett, writing as Peter Porcupine in Porcupine's Gazette, took the hard road of arguing that the British "had a right to impress [Robbins] wherever they found him," so long as he was a British subject. Even were he an impressed American, Porcupine bristled, Robbins' tactic was too extreme for sympathy:

[W] hat a bloody hag must that be, who says that the mode in which he effected his escape was such as all Americans in a like situation, should make use of? There never was any paper, except the Irish Press and the Northern Star, that ventured to promulgate such a hellish precept $\ldots{ }^{371}$

Such "atrocious principles" were "the sentiments of all the Democrats of America," Porcupine escalated. ${ }^{372}$ Yet identification of Robbins with Irish radicals was not likely to win sympathy for Federalists in a country with a substantial emigre population; British tactics in suppressing the societies of United Irishmen and the 1798 Irish Rebellion fueled the argument that Britain was indiscriminately arrogant. ${ }^{373}$

Secretary of State Pickering wrote, in naivete or cunning, to an agent in Danbury, Connecticut, seeking to corroborate that Robbins was not a denizen. ${ }^{374}$ Pickering's Danbury selectmen swore that no one had known a Jona-

370. Aurora (Philadelphia, Pa.), Dec. 12, 1799, at 2, col. 2.

371. Porcupine's Gazette (New York, N.Y.), Aug. 29 to Sept. 6, 1799 (weekly issue), at 1, col. 5 (emphasis in original). The Belfast Northern Star supported the execution of Louis XVI. See R. FOSTER, MODERN IRELAND, 1600-1972, at 266 (1988).

372. Porcupine's Gazette (New York, N.Y.), Aug. 29 to Sept. 6, 1799 (weekly issue), at 1, col. 5 (emphasis in original).

373. The 1798 rebellion was brief but extremely bloody, with deaths estimated at 30,000 (counting both sides). Hopes of substantial French assistance were disappointed; a French expedition did not land until the rebellion was effectively overcome by Protestant militia. See T. PAKENHAM, THE YEAR OF LIBERTY: THE STORY OF THE GREAT IRISH REBELLION OF 1798, at 392 (1972); MARIANNE ELLIOTT, PARTNERS IN REVOLUTION: THE UNITED IRISHMEN AND FRANCE (1982); Donnelly, Republicanism and Reaction in the 1790 's, 11 J. IRISH ECON. \& SOC. HIST. 94 (1984); R. FOSTER, supra note 371, at 280; BISHOP JOSEPH Stock, a Narrative of What Passed at KIllalla IN tHe COUNTY of Mayo aNd the PaRTS ADJACENT DURING THE FRENCH INVASION IN THE SUMMER OF 1798 (2d ed. Dublin 1800). Martial law was imposed in Ireland in March 1798; trials by court-martial were established in March 1799.

374. Letter from Timothy Pickering to James Clarke (Sept. 5, 1799), in PICKERING PAPERS, supra note 157, roll 12, at 20-22. Pickering's letter to Clarke makes plain the stir so quickly caused by Judge Bee's decision and Pickering's uneasy sense that he might have erred-"I suppose he was a British subject," says Pickering of Robbins:

You have doubtless seen in the news-papers a lengthy argument, and the opinion of Judge Bee of South-Carolina, in the case of Thomas Nash, otherwise called Jonathan Robbins, . . . Robbins asserted that he was a native of Danbury in Connecticut but tho' he had time enough after he was arrested to obtain evidence of the fact, if it had been true, yet he neglected to do it. I suppose 
than or Nathan Robbins or any family named Robbins in the town. ${ }^{375}$ The rhetorical flaw in submitting this proof was substantial since it made clear what precautions could have been taken before Lieutenant Jump gained his prisoner. It also allowed for much Republican stage business concerning the limits of the inquiry, depredations in Connecticut during the Revolution and the partisanship of Federalist officeholders. The inquiring mind wished to know "whether the selectmen of Danbury were midwives, and kept a record of the births in their townships." 376 Building upon the Federalist cast of Congregationalist Connecticut (frequently chastising Timothy Dwight and Yale Illuminati for preaching hierarchical government), the Aurora supposed that "town clerks may be found to certify to any thing that Timothy Pickering shall desire." 377 How could one credit the testimony of "party men," especially when the town records had been burnt by the British in the war? ${ }^{378}$

it was not true-I suppose he was a British subject: . . . [T] he Aurora, and other democratic papers, the constant vehicles of slander \& lies, make a handle of the circumstances to vilify the General Government and arraign the integrity of a federal judge, who on solemn argument and mature deliberation, decreed that the person in question should be delivered up . . . .

Id. Asking whether Jonathan Robbins was known in Danbury or whether any former resident fit the description of the Charleston affidavit, Pickering rather coyly put Clarke to obtain an affidavit from the Danbury selectmen which "may state the plain facts only, without any reference to my request." Id. See also Letter from Timothy Pickering to James Clarke (Oct. 11, 1799), in PICKERING PAPERS, supra note 157, roll 12 , at 167 .

375. The certification by the Danbury selectmen, dated November 15,1799 , was published in American newspapers in December 1799, together with the letters from Vice Admiral Hyde Parker, Commander George Hans Blake, and Alexander Moultrie. See, e.g., The City Gazette and Daily Advertiser (Charleston, S.C.), Dec. 4, 1799, at 2, col. 3; Aurora (Philadelphia, Pa.), Dec. 20, 1799, at 2, cols. 4-5.

376. Aurora (Philadelphia, Pa.), Feb. 12, 1800, at 2 , col. 1 .

377. Id., Mar. 10, 1800, at 2, col. 1; see id., Feb. 22, 1800, at 2, col. 1; Feb. 17, 1800, at 2, col. 1 .

378. See Extract of a letter to the Editor, dated Danbury, June 1, 1800, Aurora (Philadelphia, Pa.), June 20, 1800, at 2, cols. 3-4; also in Carolina Gazette (Charleston, S.C.), July 10, 1800, at 1, col. 4. Samuel Morse, editor of the Sun of Liberty (Danbury, Ct.), wrote in this anonymous letter to the Aurora, that Danbury selectmen now admitted a man named Robbins lived just over the border in New York, and "once had a brothar by the name of Jonathan Robbins," absent for several years. Republican Morse and the Aurora obtained this renuncia in season for the 1800 election, admonishing the readership that "Ip]ublic weakness ha[d] tolerated, in some measure, at least by its sullen silence, the delivery of this man to the British." Id.

Slapstick continued, as Federalists obtained yet another letter from Samuel Morse, admitting his reportage and disclaiming the accuracy of the selectmen's recantation, all too plainly under the threat of a libel prosecution. Danbury publisher Morse was said to be

convinced, from further examination of the subject, that the said Jonathan Robbins was not a native of this town, nor ever resided here-and that the gentlemen who so certified were not only honest and candid in giving such certificate, but certified the truth. . . . My intention in publishing the observation ... were not to reflect on the characters of those gentlemen who certified .... Gazette of the United States (Philadelphia, Pa.), Sept. 26, 1800, at 3, col. 2 (paragraphing omitted) (reprinting Morse's statement from the Sun of Liberty (Danbury, Ct.), Aug. 20, 1800); also in Philadelphia Gazette (Philadelphia, Pa.), Sept. 27, 1800, at 2, col. 2; Gazette of the United States (Philadelphia, Pa.), Oct. 1, 1800, at 3, col. 3; The Federalist New-Jersey Gazette (Trenton, N.J.), Oct. 7, 1800, at 2, cols. 3-4; Columbian Centinel-Massachusetts Federalist (Boston, Mass.), Oct. 11, 1800, at 2, col. 3 (announcing Morse's "JACOBIN CONFESSION"; "It will be remembered that the raw head and bloody bones story" of Robbins being a native of Danbury, was attempted to be bolstered by a letter from Danbury.") (emphasis in original). John Fenno taunted the Aurora for declining to publish Samuel Morse's turn-about. See Gazette of the United States (Philadelphia, Pa.), Sept. 27, Oct. 1, 2, 3, 1800, at 2. 
John Fenno of the Gazette of the United States sought comfort from the Pennsylvania Supreme Court's dictum in Respublica v. De Longchamps, conveniently authored by Chief Justice Thomas McKean, which allowed that "atrocious offenders" might be delivered "pro bono publico" by the Pennsylvania Council "to the justice of [the] country to which they belong or where the offenses were committed." ${ }^{379}$ But to citizens nervous at any resemblance between Executive power and prerogative, it was hardly a ground of comfort that Robbins might be delivered even without Jay's treaty.

The 1799 state elections gave way to anticipation of the Sixth Congress, and the call for Congressional action was heard from several quarters. "It is the duty of every man in the Union to petition congress . . . that laws declaratory of our rights should save our citizens from British murder in future," said Veritas of Maryland. ${ }^{380}$ The Aurora bandied the idea of impeaching Bee and Pickering. ${ }^{381}$ Senator Charles Pinckney of South Carolina ${ }^{382}$ in the widely circulated Letters of a South Carolina Planter called for Congress to legislate against overseas rendition of fugitives "unless a bill is found against them by a grand jury." Pinckney's Letters were printed in the Aurora ${ }^{383}$ and the Charleston papers, ${ }^{384}$ in numerous other Republican papers, ${ }^{385}$ and in pamphlet form. ${ }^{386}$ Pinckney sent copies to Madison, also advising on the best

379. 1 U.S. (1 Dall.) 111, 116 (Pa. 1784); see Gazette of the United States (Philadelphia, Pa.), Aug. 22,1799 , at 3 , col. 2 .

380. Aurora (Philadelphia, Pa), Aug. 20, 1799, at 2, col. 2. "I trust this affair will not be suffered to sleep in silence-Our Representatives are acquainted with it, it was not done in a corner-it calls loudly for a close investigation," said Robert Slender in his collected LETTERS ON VARIOUS INTERESTING AND IMPORTANT SUBJECTS, supra note 359, at 127 (issued December 30, 1799).

381. Aurora (Philadelphia, Pa.), Oct. 11, 1799, at 2, col. 1 (emphasis in original):

If the case of [Senator William] Blount did not furnish a disgraceful precedent of the inefficiency of an impeachment-we should think that Judge Bee \& the writer of the letter who 'advised and requested' the delivery of a citizen into the murderous talons of the British government, should be arraigned at the bar of the nation, and fairly tried for their acts in that lamentable deed.

382. Republican Charles Pinckney was author of the Pinckney Plan in the Philadelphia Convention, and a former Governor of South Carolina-not to be confused with his Federalist cousins Charles Cotesworth Pinckney, who ran for Vice President in 1800, and Thomas Pinckney, who concluded the 1795 Treaty with Spain and ran for Vice President in 1796.

383. Aurora (Philadelphia, Pa.), Oct. 9, 1799, at 2-3; Oct. 23, 1799, at 2-3.

384. The City Gazette and Daily Advertiser (Charleston, S.C.), Sept. 6, 1799, at 1-3; Oct. 4, 1799, at 2-3; Oct. 28, 1799, at 1-2; Carolina Gazette (Charleston, S.C.), Sept. 12, 1799, at 2-3; Oct. 10, 1799, at 1-2; Oct. 31,1799 , at 2-3.

385. E.g., Centinel of Freedom (Newark, N.J.), Nov. 5, 1799, at 1-2; American Mercury (Hartford, Conn.), Oct. 31, 1799, at 2; Nov. 7, 1799, at 1-2; Nov. 14, 1799, at 1-2; Nov. 21, 1799, at 1.

386. C. PINCKNEY, THREe LETTERS, WRITTEN, AND ORIGINALlY PUBLISHED, UNDER THE SigNaTURE OF A SOUTH CAROLINA PLANTER (Aurora, Philadelphia 1799), available in EARLY AMERICAN IMPRINTS, 1639-1800, supra note 116 (Evans No. 36124). The pamphlet was also printed in Charleston as THREE LETTERS, ADDRESSED TO THE PEOPLE OF THE UNTTED STATES, WHICH LATELY APPEARED UNDER THE SIGNATURE OF "A SOUTH-CAROLINA PLANTER" (T.C. Cox, Charleston Dec. 1799), available in EARLY AMERICAN IMPRINTS, 1639-1800, supra note 116 (Evans Nos. 36122 \& 36123). Pinckney's Letters varied slightly in title from one printing to another. In the Charleston pamphlet they were, Letter I: On the Case of Jonathan Robbins, Letter II: On the Recent Captures of British Cruisers, and the Right of a Citizen to Expatriate Himself, and Letter III: On the Claims of the British Creditors, and the Proceedings of the British Commissioners Under the Sixth Article of Mr. Jay's Treaty. The first letter was also reprinted as a pamphlet in Baltimore. See CASE OF JONATHAN ROBBINS, EXAMINED BY CHARLes PINCKNEY, ESQ. (Warner \& Hanna, 
method for choosing Virginia Presidential electors to serve "the republican interest." 387 Jefferson congratulated Pinckney on his writing's power. ${ }^{38}$ The Aurora complained in its columns that Federalists in the Post Office had attempted to "suppress[ ]" and "mutilat[e]" the issues with Pinckney's essays, ${ }^{389}$ and promptly reprinted them. ${ }^{350}$ Pinckney was highly critical of Judge Bee for daring to decide the case, when Congress had chosen to restrict district court jurisdiction to crimes of minor penalty. A district judge's power to commit for trial on more serious matters was no answer, for there is "surely an astonishing difference between a mere commitment for trial and a delivery over to a foreign tribunal." Pinckney credited the good faith of Adams and Pickering, concluding that "neither of them meant to influence the opinion of the judge" and that neither knew of Robbins" belated claim of citizenship. But if Robbins was a case of unwarranted fears, "the noise it has made will show the extreme impropriety of the higher executive officers of our government ever touching in the most distant manner on any subject that may come before the judicial." Pinckney also called for a policy favoring armed neutrality, to prevent British visitation on American ships which gave the occasion for impressment. ${ }^{391}$

Baltimore 1799), available in EARLY AMERICAN IMPRINTS, 1639-1800, supra note 116 (Evans No. 36121). These Letters of a South Carolina Planter are the "pamphlet of Pinckney" remarked upon by William Cobbett in correspondence with Edward Thornton, secretary to the British Legation, on March 6, 1800; Cobbett fled to New York in late 1799 to avoid a Pennsylvania judgment for libel, ceasing publication of Porcupine's Gazette, but began another journal, the Rush-Light. Liston and Thornton may well have supposed Cobbett could further serve as a polemicist in the Robbins debate. Cobbett's biographer, the eminent G.D.H. Cole, may be forgiven for wholly mistaling Cobbett's reference to Pinckney in light of innumerable redeeming virtues. See LETTERS FROM WILLIAM COBBETT TO EDWARD THORNTON WRTTEN IN THE YEARS 1797 TO 1800, at 67, 68-69 (G.D.H. Cole ed. 1937).

387. Letter from Charles Pinckney to James Madison (Sept. 30, 1799) (emphasis in original) (enclosing copies of Charleston City Gazette and Daily Advertiser of Sept. 6, 1799 and Oct. 4, 1799), in 16 THE PAPERS OF JAMES MADISON (J. Stagg ed. forthcoming 1990).

A Decision has lately taken place in Charleston by our Federal Judge which makes great Noise .... at the request of a Number of our Citizens I have examined it \& written the Piece inclosed ... which I request you to have republished in your State papers if you think it proper. It is of importance \& is another of the Effects produced by that Treaty, which taking this, the Claims under that Article on the United States Treasury for British Subjects \& the Captures, begins to develop all its consequences.

Madison's copies of the Pinckney articles are preserved in his portfolio of newspaper clippings (Madison Papers, Library of Congress, series 7, container 3).

388. Letter from Thomas Jefferson to Charles Pinckney (Oct. 29, 1799), in 7 THE WRIrTNGS of THOMAS JEFFERSON, supra note 18, at 397: "I have no doubt the piece you enclosed will run through all the republican papers, \& carry the question home to every man's mind."

389. Aurora (Philadelphia, Pa), Oct. 25, 1799, at 2, col. 2.

390. Id., Oct. 26, 1799, at 3; Oct. 28, 1799, at 3.

391. Pinckney shows an interesting variant in Southern Republican thinking. Although extradition should be forbidden by statute unless a true bill was returned by grand jury, nonetheless Judge Bee acted correctly in declining to hold the treaty unconstitutional:

In one thing I perfectly agree with Mr. Bee, and that is, in his avoiding to question the constitutionality of the treaty, although I think it unconstitutional. On no subject am I more convinced, than that it is an unsafe and dangerous doctrine in a republic, ever to suppose that a judge ought to possess the right of questioning or deciding upon the constitutionality of treaties or laws, or any act of the legislature. It is placing the opinion of an individual, or of two or three, above that of both branches of Congress, a doctrine which is not warranted by the constitution, and will not I hope long have many advocates in this country. 
Washington died on December 14, 1799, and even the Republican papers suspended polemics to mark the event with black-bordered announcement. ${ }^{392}$ The patriot king who hated party dissension, who took renewed command of the army in 1798 to signal the sobriety in which the Government viewed the French war signals of the XYZ affair, who offered little public support to Adams' heroic decision to spurn the High Federalist call for war by sending a renewed embassy to France, was now removed from controversy. It is tempting to suppose that his death may have been a sobering event, sign that the decade of political scission had been too wearing. Adams' eulogy contained a graceful note seeking to quiet the suspicions between Monocrats and Jacobins, praising Washington as a man who showed the personal virtue that outshines rank or ideology. "The attributes and declaration of royalty, could have only served to eclipse the majesty of those virtues, which made him[,] from being the model citizen, a more resplendid luminary." 393

\section{TREaTy Power REDUX: THE CONTEST OF Gallatin AND MARShall}

The Sixth Congress was to be the last federal legislature held in Philadelphia, as if the Founding might finally be completed. John Marshall took his seat on December 2, 1799, as a newly elected Virginia Representative. In the Republicans' opening legislative gun in the Robbins affair, Edward Livingston of New York, veteran of the Jay Treaty fight, argued that "provision ought to be made, by law, for carrying into effect the twenty-seventh article of the Treaty of Amity, Commerce, and Navigation, between the United States and the King of Great Britain." The Jay Treaty was "unjust, impolitic, and cruel," showing in its recent construction that "a citizen of the United States might be dragged from his country, his connexions, and his friends, and subjected to the judgment of an unrelenting military tribunal." ${ }^{394}$ The President's request for delivery was "a dangerous interference of the Executive with Judicial decisions" in "sacrifice of the Constitutional independence of the Judicial power." 395 Washington's death did not deflect Republican aim at strong theories of Execu-

\footnotetext{
C. PINCKNEY, On the Case of Jonathan Robbins, in THREE LETTERS, WRITTEN AND ORIGINALLY PUBLISHED UNDER THE SIGNATURE OF A SOUTH CAROLINA PLANTER, supra note 386, at 19.

392. E.g., Aurora (Philadelphia, Pa.), Dec. 20, 1799, at 2, col. 2.

393. John Adams, Eulogy on the Death of Washington, reprinted in Aurora (Philadelphia, Pa.), Jan. 2, 1800 , at 2 , col. 2 .

394. 10 ANNALS OF CONG., 6th Cong., 1st Sess. 511 (Feb. 4, 1800).

395. Id. at 533 (Feb. 20, 1800). It is interesting to note what Livingston was willing to concede in the House debate-that Robbins probably was not American, and that his affidavits were properly rejected as evidence. Livingston "declared that he did not believe a word of the affidavit; but he believed Nash was an Irishman, and that he entered on board and committed all the crimes charged to him." Id. at 545 (Feb. 25,1800 ). As to the affidavit, "Surely he could not be so far mistaken in his law knowledge as to be thought to have said that the culprit could be evidence in his own behalf." Id. at 544 (Feb. 25, 1800).
} 
tive power. Livingston moved to censure Adams, ${ }^{396}$ while James Bayard of Delaware offered a counter resolution approving "the conduct of the Executive Government" as "conformable to the duty of the Government, and to the obligations of good faith" of the treaty ${ }^{397}$ Calls were made for the production of papers from the Executive Branch, ${ }^{398}$ and the South Carolina court proceeding. ${ }^{399}$

The Brigstock case was most troublesome to the House. How could the treatment of mutineers from the Hermione have changed in the course of sixteen months? John Nicholas of Virginia supposed that the change in the Executive's view of its treaty obligations could only have come at the instance of the British. ${ }^{400}$ Livingston introduced the available court records of the Brigstock prosecution, ${ }^{401}$ and Pennsylvania Republican Albert Gallatin called for any treaty communications with the British, a resolution he pursued past its first defeat. ${ }^{402}$ Federalist Robert Goodloe Harper of South Carolina denounced Livingston for a "pen dipped in gall" and for extending debate with an eye to the coming elections; "this subject [had] been talked of for eight months past, and pasteboard figures of Jonathan Robbins been exhibited at every election ground in the United States." ${ }^{403}$ Harper pointed out that Robbins' claim of

396. Id. at 532-33 (Feb. 20, 1800). Federalist Robert Goodloe Harper of South Carolina accused Livingston of seeking "the direct road to an impeachment of the President," id. at 552 (Feb. 26, 1800), a suggestion warranted by Livingston's statement that the House was sitting both "in their ordinary legislative capacity" and "as the special guardians of the Constitution and Laws, and the high inquest for the people of the United States." See Virginia Argus (Richmond, Va.), Feb. 14 (misnumbered as Feb. 18), 1800, at 2, col. 4. Livingston argued the Robbins case should have been prosecuted in the United States under the 1790 Crimes Act. Jurisdiction, scope of the treaty, and investigation of a claim of citizenship and impressment were "all matters exclusively of judicial inquiry" on which the Executive should not have directed the court. 10 ANNALS OF CONG., 6th Cong., 1st Sess. 533 (Feb. 20, 1800).

397. Id. at 526 (Feb. 17, 1800).

398. Adams produced the letters of May 23, June 3, and July 1,1799, the certificates of the Danbury selectmen, and Sir Hyde Parker's reports to Minister Robert Liston and Consul Benjamin Moodie after the execution. Id. at 516-18 (Feb. 7, 1800).

399. Some of the Republicans seemed equally confused about the relationship of the judiciary and the Executive, calling on the President to produce the records from the South Carolina district court. Marshall successfully countered, asking, "Was [the President] to be a menial to the House" in sending for the papers of another department? Id. at 565 (Feb. 27, 1800) (emphasis added). The motion for a copy of the South Carolina records was defeated, though members had available to them the extensive newspaper accounts of Judge Bee's decision.

400. Id. at 584 (Mar. 3, 1800).

401. Livingston's record was ordered to be printed by the House on March 3,1800, but no copy is included in the Annals of Congress. Early Congressional documents were not issued in serial form. As is sometimes the case, the plainest record of the House document is found in a contemporaneous newspaper account. See The Philadelphia Gazette (Philadelphia, Pa.), Mar. 6, 1800, at 2, cols. 1-4. An untitled pamphlet-listed without provenance in C. SHIPTON, THE AMERICAN BIBLIOGRAPHY OF CHARLES EVANS, No. 38723 (1955) (volume 13, C. EVANS, supra note 116)-is likely the printing ordered by the House on March 3, 1800. (The pamphlet reprints a certified copy of the court record dated March 1, 1800. Shipton errs in ascribing the March 1, 1800 date to the pamphlet itself.)

402. See 10 ANNALS of CONG., 6th Cong., 1st Sess. 584 (Mar. 4, 1800) (resolution introduced); id. at 587 (Mar. 4, 1800) (defeat of motion to consider resolution); id. at 588-95 (Mar. 5, 1800) (renewed debate).

403. Id. at 590 (Mar. 5, 1800). The Philadelphia Gazette, Mar. 5, 1800, at 3, col. 2, echoed Harper's complaint: "The hue and cry of Executive interference... has been protracted with an industry unworthy 
citizenship "was not made till a month after the President had acted on the case," 404 which was true enough, but then stepping out far beyond his knowledge, Harper declared,

It is scarcely possible that any requisition was ever made by any British agent in the case in New Jersey. Can it be supposed that the President would be guilty of such a boyish trick - of such versatility of conduct in his dealings with a foreign nation-as, in a few months, to put a different construction upon one and the same action? ${ }^{405}$

As if in reserve, Harper also tried to build upon the Republican notion of jury authority - the jury's right to find law meant the New Jersey acquittal could be interpreted as a finding of a lack of jurisdiction. An Executive's turn-about might be deference to the popular jury's view of the law. With these arguments, Gallatin's resolution for production of Anglo-American diplomatic correspondence was defeated-narrowly, by vote of the Speaker, 46 to $474^{406}$ The House Republicans were not given to know that the British indeed had made a requisition in the Brigstock case and, de facto, been refused. Pickering's "boyish trick" of versatility in interpreting the Jay Treaty did not come to light.

The major theoretical addresses of the debate were delivered by Albert Gallatin and John Marshall, the Pennsylvania Republican against the Virginia Federalist. Gallatin was famous as Hamilton's long-time rival in fiscal matters, expelled from the Senate following Federalist attack when his nine-years naturalization was questioned, whispered to have instigated the Whiskey Rebellion, who would go on to serve President Jefferson as Secretary of the Treasury. John Marshall was already noted for his part in the XYZ affair, had carefully reefed sail in the Alien and Sedition Act debates, and ran for Congress at Washington's urging to serve as a spokesman for the middle opinion of Virginia.

Gallatin's argument for the Republicans is, oddly enough, not reported in the Annals of Congress. ${ }^{407}$ But notes of the speech can be found in Gallatin's

the cause. The approaching election is to evince the popular sentiment on this subject. . . [W] lament to behold even the Councils of our Country aiding and abetting."

404. 10 ANnals OF ConG., 6th Cong., 1st Sess. 591 (Mar. 5, 1800) (emphasis added).

405. Id.

406. Id. at 594-95 (Mar. 5, 1800).

407. Before 1824 , debates in the Congress were reported only in newspaper accounts and pamphlet literature. Under the Constitution, Article I, section 5, each House must keep a "Journal of its Proceedings," but these include only formal motions and dispositions, not the course of discussion. See JOURNAL OF THE HOUSE OF REPRESENTATIVES OF THE UNITED STATES AT THE FIRST SESSION OF THE SLXTH CONGRESS (Printed by W. Ross, Philadelphia n.d.), available in EARLY AMERICAN IMPRINTS, 1639-1800, supra note 116 (Evans No. 38748). From 1824 to 1837, Joseph Gales and William Seaton began systematic Congressional reporting in the Register of Debates in Congress, supplemented in 1833 by the Congressional Globe. The earlier debates of 1789 to 1824 were partially reconstructed by Gales and Seaton from newspaper and pamphlet accounts and published from 1834 to 1857 as the Annals of Congress.

The Annals report Gallatin's speech from the Robbins debate as two hours long, but no text is supplied. 10 ANNALS OF CoNG., 6th Cong., 1st Sess. 596 (Mar. 6, 1800). The Aurora carried extended, if delayed, 
collected personal papers and provide the substance. ${ }^{408}$ Gallatin complained of the President's broad use of Executive power. Action upon the treaty article should have awaited legislation by the House. There was no reserve of lawmaking authority in the Presidency to cure omissions even where the exercise was designed to carry out purposes assigned by treaty. In this sense, a President's power of execution was almost ministerial in nature. Executive power could not be used to bridge gaps in the law.

No law has been enacted by Congress to carry into effect the 27 th Art[icle] of [the] British Treaty. This Article is the supreme law of the land[.] But can a law be executed when the means \& manner of executing it are not pointed out by law? This law (the Article itself) does not designate the officers by whom the same shall be executed[.] $]^{409}$

Gallatin admitted the constitutional responsibility of the Presidency-the constitutional warrant assigned to the President of accomplishing a result, of placing the laws in working execution. "The President, it is true, is by the Constitution, enjoined 'to take care that the laws be faithfully executed[.] "'410 But Gallatin sought to reconcile this duty of faithful execution with deference to the role of the House by discerning a "defect" in the treaty. The problem was not merely the unresolved pull between keeping foreign promises and honoring democratic voice. Rather there was a formal problem, a gap in the law. "[C]an the power of executing supply the defect of the law itself?" 411 Even in Great Britain "a law was thought necessary," argued Gallatin, ${ }^{412}$ perhaps an unfair analogy since there is no Article VI in the unwritten British constitution. As American analogy, Gallatin took heart from the 1790 consular convention with France, which permitted the arrest and delivery of naval deserters. ${ }^{413}$ Though the convention was potentially awkward for Republicans, as proof even they saw the need for maritime discipline, Gallatin used it as an example of proper deference to the House's power. The consular convention

accounts of most of the House debates in the Robbins affair. See Aurora (Philadelphia, Pa.), Apr. 15-19, 21, 23-25, 1800 (reporting debates of February 24-27, and March 3-4, 1800). But on April 26, 1800, just before reaching the Gallatin-Marshall duel of March 6 and 7, the Aurora's news columns were diverted by the trial of newspaper editor Thomas Cooper for seditious libel.

408. Gallatin's personal papers are in the New-York Historical Society. A scholarly edition of his papers, sponsored by the National Historical Publications and Records Commission and the National Endowment for the Humanities, is underway, and should provide an extremely interesting vantage of this rival to Hamilton in crucial matters of the early republic's fiscal policy. I am grateful to Elaine Pascu, Associate Editor of the Gallatin Papers, for providing microfilm copies of the pertinent papers from 1800 .

409. A. Gallatin, Observations on Robbins's Case (n.d.), in PAPERS OF ALBERT GALLATIN, roll 4, at 385 (New-York Historical Society).

410. Id.

411. Id.

412. Id.

413. Convention Between His Most Christian Majesty and the United States of America for the Purpose of Defining and Establishing the Functions and Privileges of Consuls and Vice-Consuls, United StatesFrance, art. 9, 8 Stat. 106, T.S. No. 84 (signed Nov. 14, 1788; proclaimed Apr. 9, 1790). 
"even declared that Judges \& proper officers should assist in the executionYet merely because the Convention did not designate what Judges \& what officers should execute it, legislative assistance was thought requisite. . . . And a law was accordingly past." 414

For Gallatin, Adams' action in regard to Judge Bee was improper interference. Interpretive questions concerning the treaty-whether the alleged offense was committed in the "jurisdiction" of Great Britain, whether the offense was "murder" as designated by the treaty-were "in their nature properly points of law" assigned to the judiciary by function and by Article III. (Of all early Presidents other than Madison, Adams was most eminently schooled in the law of nations and civilian writers, but an ad hominem defense is to mistake the point of Gallatin's address.)

$1^{\text {st }}$. They are in their nature properly points of law-Whether "piracy \& murder" committed on board of a public ship of Great Britain on the high seas, may be said to be committed within the exclusive jurisdiction of Great Britain? is a question depending on the law of nations-Whether an offence committed within the concurrent jurisdiction of Great Britain \& America, must be exclusively tried by Great Britain, when falling within the description of the offences designated by the $27^{\text {th }}$ Article? is a question depending on the general principles of law $\&$ on the construction \& meaning of the particular law (the Article)-Whether the offense of "piracy \& murder" comes within the description of murder as intended by the Article? is a question depending on the legal ideas attached to that offence by the laws of both Nations or by the law of nations.

$2^{\text {nd }}$. They are placed within the exclusive cognizance of the judiciary by the Constitution, which declares that "the judicial power shall extend

414. A. Gallatin, Observations on Robbins's Case (n.d.), in PAPERS OF ALBERT GALLATIN, supra note 409, roll 4, at 385. See An Act concerning Consuls and Vice-Consuls, § 1, 1 Stat. 254 (Apr. 14, 1792). One might quarrel again with the analogy, for in the consular arrangement applications were not made to the President who, one could argue, has a singular duty of faithful execution. Rather, the consular treaty in Article 9 provided that consuls should "address themselves to the courts, judges, and officers competent." Nor did the 1792 implementing statute add any procedural protections to the 1790 consular arrangement, beyond a res gestae demonstration that Congress would allocate federal court jurisdiction:

[Dlistrict judges of the United States shall ... within their respective districts be the competent

judges, for the purposes expressed in the ninth article of the said convention, and it shall be incumbent on them to give aid to the consuls and vice-consuls of the King of the French, in arresting and securing deserters from vessels of the French nation according to the tenor of the said article ....

1 Stat. at 254. United States Marshals were instructed by the statute to provide aid "where by any article of the said convention, the consuls and vice-consuls of the King of the French are entitled to the aid of the competent executive officers of the country, in the execution of any precept," with aid to be given "according to the tenor of the stipulations." The normal jails for federal confinement should be used "whenever commitments to the jails of the country shall become necessary in pursuance of any stipulation of the said convention." Id. The addition by Congress clarified which officials had authority and asserted control of federal courts' jurisdiction, but did not add any substantive safeguards in the delivery of wandering salts. 
to all cases in law \& equity "arising under treaties \& to all cases of admiralty \& maritime jurisdiction." 415

Gallatin argued that in the Brigstock case, American judicial power had been thought sufficient to reach crimes committed on a public warship, and hence the question of how to characterize those crimes in the treaty must also fit within Article III. ${ }^{416}$ As example of the judiciary's competence to construe treaties under Article III, even though it involved international performance, Gallatin drew forth the Captain Barre case from the French consular convention, in which return of an alleged naval deserter was sought by an application for mandamus from the Supreme Court to a district judge who declined to order the deserter's return. ${ }^{417}$ The Executive had been willing to submit to the Court's authority in Washington's term, but no longer. On the treaty merits, Gallatin declared the offense on the Hermione could not be within the exclusive jurisdiction of Great Britain, because piracy was cognizable by American courts, and the murder would merge in the piracy. ${ }^{418}$ Gallatin also remonstrated that a district judge had no right to decide a jurisdictional question concerning a circuit court; Bee "decided the question of jurisdiction not between himself \& another Court, but between a superior Court \& a foreign country."419

Marshall saved his entrance till the end of the debate, ${ }^{420}$ unveiling his once famous defense of strong Executive power in foreign affairs. Marshall will veer to the edge of a High Federalist reading of treaty power; the Marbury Marshall is due for serious re-examination in light of this. Marshall's argument rests textually upon the President's assigned duty to see that the law is faithfully executed, and structurally upon the notion that some single official should have auditable responsibility for treating with foreign opponents and friends.

415. A. Gallatin, Observations on Robbins's Case (n.d.), in PAPERS OF ALBERT GALLATIN, supra note 409 , roll 4, at 385 (emphasis and question marks in original; words crossed out in original manuscript are omitted).

416. One phrase of Gallatin's planned address suggests he may have been aware of the British request for rendition in the Brigstock case: "[T] he district judge [in Brigstock] had, previous to the requisition being made, committed the person for trial." Id. (emphasis added).

417. See United States v. Lawrence, 3 U.S. (3 Dall.) 42 (1795), cited in Marbury v. Madison, 5 U.S. (1 Cranch) 137, 148 (1803) (oral argument of Charles Lee).

418. Wilson's scruples about the reach of the 1790 piracy statute were apparently not shared by Gallatin; nor did Gallatin, in the service of this issue, confess any embarrassment in proposing that federal criminal law could extend on board a British frigate at war.

419. A. Gallatin, Observations on Robbins's Case (n.d.), in PAPERS OF ALBERT GALLATIN, supra note 409 , roll 4 , at 385 .

420. Marshall, like Gallatin, argued only after a vote of the Committee of the Whole was taken to reject Livingston's motion of censure. Still pending were the formal issue whether the House would agree with the Committee of the Whole, and Bayard's motion to approbate the President's conduct. 
Marshall's argument in the House ${ }^{421}$ was prefaced by an earlier unsigned essay in the Virginia Federalist, ${ }^{422}$ and we will discuss the two in tandem.

Congressman Marshall's constitution is governed by a rule of efficacy. If a power is necessary to the effective action of the United States in international compass, then interpretation should find a footing for that power. By Article VI, treaties are part of the law of the land, and the President has the constitutional duty to see that the law is faithfully executed. If the House of Representatives insists on seeking a role in the treaty process by refusing to pass implementing legislation, this cannot disable (we may read Marshall) the United States from fulfilling its international obligations even if it requires a strong doctrine of Presidential treaty execution. A treaty is supreme law for the House

421. Marshall's speech is reproduced at 10 ANNALs OF Cong., 6th Cong., 1st Sess. 596-618 (Mar. 7,1800 ). The survival of Marshall's argument in a complete form, appears to be due to a pamphlet issued in 1800. See SPEECH OF THE HON. JOHN MARSHALl, DELIVERED IN THE HOUSE OF REPRESENTATIVES OF THE UNITED STATES, ON THE RESOLUTION OF THE HON. EDWARD LIVINGSTON, RELATIVE TO THOMAS NASH, Allas JoNATHAN ROBBINS (Philadelphia, Printed at the Office of "The True American" 1800); also in Salem Gazette (Salem, Mass.), May 6, 1800, at 1, col. 2. The Marshall pamphlet is available in EARLY AMERICAN IMPRINTS, 1639-1800, supra note 116 (Evans No. 37887), and in 4 THE PAPERS OF JOHN MARshall 82-109 (C. Cullen \& H. Johnson eds. 1984). Of course a pamphlet issued after the event may not reflect the speech as delivered. See Letter of Timothy Pickering to James Winchester (Mar. 17, 1800), in PICKERING PAPERS, supra note 157, roll 13, at 281 ("Mr. Marshall's speech on the subject will be printed, after he has himself corrected it."). A contemporaneous account of Marshall's speech is provided by Gallatin's running notes. See A. Gallatin, Observations on Robbins's Case (n.d.), in PAPERS OF ALBERT GALLATIN, supra note 409, roll 4, at 386-87. In live delivery Marshall apparently paid more immediate attention to the question whether the President improperly interfered with Judge Bee.

422. The essay in the Virginia Federalist is titled Communication, see Virginia Federalist (Richmond, Va.), Sept. 7, 1799, at 3, col. 1, and styles itself as an answer to "several strictures" in a "late paper" of the Richmond Examiner. The attribution of the Virginia Federalist essay to Marshail was made obliquely by Federalist law reporter John Elihu Hall in 1821, and explicitly by Francis Wharton in 1849. See 1 THE JOURNAL OF JURISPRUDENCE: A NEW SERIES OF THE AMERICAN LAW JOURNAL 28-32 (J. Hall ed. 1821) (reprinting essay by "a gentleman who now occupies one of the most important stations in our government") (one should note that the year before Henry Wheaton had reprinted Marshall's House argument in the Appendix to the U.S. Reports, see 18 U.S. (5 Wheat.) app. (1820)); F. WHARTON, supra note 6, at $404 \mathrm{n}$. (essay was "by Mr. Marshall"). The modern edition of the Marshall papers includes the Virginia Federalist essay as one of Marshall's works. See 4 THE PAPERS OF JOHN MARSHALL, supra note 421, at 23-28. Editor Charles Cullen states that the attribution was based on Hall and Wharton. (Conversation, Apr. 9, 1990.)

The Virginia Federalist essayist and Congressman Marshall differ in their understanding of the territorial limits of Article III, but are alike in much else. The Virginia Federalist theory of political questions in treaties is also akin to Marshall's post-Robbins legislative work, see infra note 501. Marshall's surviving correspondence shows he was in Richmond, Virginia in late August 1799, where the Virginia Federalist essay was published. See 2 I. RHODES, THE PAPERS OF JOHN MARSHALL: A DESCRIPTIVE CALENDAR 354 (1969). Based on the style and substance of argument, and Hall's claim during Marshall's lifetime, I am inclined to accept the attribution.

Madison was Marshall's provoking critic, suggested Wharton; the Richmond Examiner's strictures were "said to emanate from Mr. Madison." Wharton did not describe his evidence, and the provoking Examiner essay has been lost for the last 140 years; Southern newspaper holdings frequently did not survive climate and war. A discovery in the Philadelphia Aurora may advance this mystery of Marshall and Madison. On November 5, 1799, at 2, cols. 4-5, the Aurora reprinted an essay by "Hale" from the Examiner attacking Adams and Bee, which could be the lost essay. The current editor of the Madison papers, J.C.A. Stagg, reports that the exercise drolly called "stylometric" analysis, comparing the brief Hale essay to other Madison writings for frequencies of word usage, is inconclusive (Letter, Apr. 10, 1990). Yet we should recall that Madison and Peter Freneau were college classmates and remained political confrères; it seems likelier for Marshall to have answered a critic of Madison's standing. 
as much as the States, and the House cannot supersede a treaty by omission of action. Arguments of a "gap" in the law are factitious.

The gentleman from Pennsylvania contends that, although this [rendition under the treaty] should be properly an Executive duty, yet it cannot be performed until Congress shall direct the mode of performance. ... The Executive, he says, can, no more than courts, supply a legislative omission.

... [A]Ithough the Executive cannot supply a total Legislative omission, yet it is not admitted or believed that there is such a total omission in this case.

The treaty, stipulating that a murderer shall be delivered up to justice, is as obligatory as an act of Congress making the same declaration. If . . . there was an act of Congress in the words of the treaty, ... could the President, who is bound to execute the laws, have justified the refusal to deliver up the criminal, by saying, that the Legislature had totally omitted to provide for the case? ${ }^{423}$

Marshall urges the same point in the Virginia Federalist essay. Adams acted properly to execute the treaty even without implementing legislation. In the grand deductive style so characteristic of his arguments, Marshall sees right reason and the nature of things as substitute for any expressed will of Congress, allowing Executive design of a procedure to implement extradition without aid of the House:

There must ... have been some mode of carrying the provision of the treaty in this respect into execution, or else the article would be nugatory; and it would be absurd to suppose the parties meant to stipulate for a thing which could not be performed. ... The treaty has not pointed out any mode, and therefore we must recur to principles and the nature of things in order to discover it. ${ }^{424}$

The nature of things, in this view, could not involve dependence on another political organ able to nullify the treaty. ${ }^{425}$

On Marshall's behalf, we may muster the example of judicial interstitiality. The constitutionally assigned duty of execution of treaties could be viewed as

423. 10 ANNals OF CoNG., 6th Cong., 1st Sess. 614 (Mar. 7, 1800).

424. Virginia Federalist (Richmond, Va.), Sept. 7, 1799, at 3, col. 2 (paragraphing elided); also in 4 THE PAPERS OF JOHN MARSHALL, supra note 421, at 23, 24-25 (with slight textual variation).

425. If English practice were to guide, Marshall's suggestion that the treaty must be self-executing without further action from the domestic legislature was vulnerable, since the Parliament was called upon to and did pass implementing legislation. Act of July 4, 1797, $37 \mathrm{Geo.3,} \mathrm{ch.} 97$. Our modern notion of selfexecution in treaties calls upon the interpreting court to decide whether the signatory parties intended the substantive standard of the treaty to be fleshed out by further political provision. But Marshall could have persuasively argued that the differing structure of English government justified an asymmetry in expectations whether implementing legislation was required. Within a parliamentary system, an English government signing a treaty would be confident of a majority in Commons, and so did not need self-executing effect in order to keep faith in its foreign promises. 
a head of power for the Executive to make the ancillary rules necessary for execution-just as analogously, courts have created remedies for the enforcement of claims. Federal courts have also deemed admiralty and maritime jurisdiction to be a head of power to create or receive the necessary substantive and procedural rules for prize, salvage, and insurance. ${ }^{426}$ The rules of Executive implementation should be faithful to the tenets of American political philosophy, but their basis for recognition as law would be the assignment to the Presidency of a constitutional duty of action. ${ }^{427}$ Congress can choose to prescribe a different mechanism. "Congress, unquestionably, may prescribe the mode," Congressman Marshall allows, "and Congress may devolve on others the whole execution of the contract; but till this be done, it seems the duty of the Executive department to execute the contract by any means it possesses." ${ }^{\text {"28 }}$ Congress cannot usurp the treaty power by inaction.

Congressman Marshall and the Virginia Federalist Marshall differ as to the available instruments for the Executive's purpose. Both suggest that the possibility of involving a federal judge in the matter is not precluded by the lack of a jurisdictional statute. Extraordinarily interesting for how we should read

426. As a more controversial analogy, one could point to the early exercise of diversity jurisdiction. Before Erie Railroad Co. v. Tompkins, 304 U.S. 64 (1938), diversity jurisdiction was guarded as a head of power to receive and enforce a federal law merchant or general commercial law. See Swift v. Tyson, 41 U.S. (16 Pet.) 1 (1842); Watson v. Tarpley, 59 U.S. (18 How.) 517, 521 (1855) ("[A]ny state law or regulation, the effect of which would be to impair the rights thus secured [under general commercial law], or to devest the federal courts of cognizance thereof, . . . must be nugatory and unavailing.").

The debate over Swift, Erie, and the 1789 Rules of Decision Act has claimed many lives; those who wonder at any federal interest in a common law of contracts may have failed to understand the place of lex mercatoria as part of the law of nations, an interstate and international law merchant. Public and private law were more closely linked in early view; disregarding foreign commercial obligations could bring "the greatest of public calamities" upon the whole, as Madison reminded in his Vices. Madison's view of state governments, as dominated by the aggregate interests of debtors or creditors, helps place $S w i f t$ in perspective. State courts and legislatures might be assumed to act in good faith toward state citizens, but lex mercatoria should be enforceable in diversity jurisdiction for unpopular foreign plaintiffs whose commercial interest differed from the aggregate interests of state citizens. Banco Nacional de Cuba v. Sabbatino, 376 U.S. 398 (1964), also should remind us of these original roots of Swift. Sabbatino treats "federal common law," yet this post-Erie category absorbed many of the doctrines of the law of nations formerly part of the "general common law" or "general principles of jurisprudence" of Swift. The "act of state" doctrine is part of a federal common law, Sabbatino presently instructs us, because it is tied to the management of foreign affairs. In the early Republic, assuring payment of foreign debts had the same importance to foreign relations, and the relation of one American state to another was similarly bound by principles of the law of nations. The scope of the common law of interstate and foreign commerce was defined, if you like, by parties to the contract rather than movement of goods. States still could effectively govern transactions among their own citizens; by section 11 of the 1789 Judiciary Act, 1 Stat. 79, an out-of-state creditor could not sue in federal diversity jurisdiction where he obtained the claim by assignment from an in-state creditor, except for foreign bills of exchange. It is hardly surprising that out-of-state creditors were left to obtain protection by choice of trial forum, in an era when Supreme Court review of state court decisions was still keenly resented. Rules of customary international law were not subject to appeal as federal questions until Sabbatino; see, e.g., New York Life Ins. Co. v. Hendren, 92 U.S. 286 (1875).

427. We do not refrain in our own century from giving the President massive authority to make law through Executive orders and administrative regulations. While the apparat of the modern regulatory state requires legislative participation through appropriations, Marshall's President seeks to act only in discrete instances, through a Cabinet Secretary already charged with the subject matter.

428. 10 AnNals of Cong., 6th Cong., 1st Sess. 614 (Mar. 7, 1800). 
Marbury and Martin v. Hunter's Lessee, both Marshalls suppose Article III is self-executing; judicial power need not depend upon House assignment of jurisdiction. The Virginia Federalist Marshall argues that the judiciary could be called upon by the President to assist in extradition because the "Judicial power extended to Treaties"; ${ }^{429}$ an inferior federal judge could exercise Article III "arising under" jurisdiction directly, even without an assignment of jurisdiction by Congress, even where other jurisdiction had been expressly assigned. ${ }^{430}$ Bee had adverted to the same sense, that in a young Republic whose gears have not yet been fitted, jurisdiction might have to be assumed "otherwise, there would be a failure of justice." 431 Congressman Marshall argues that Article III courts may function independently of Congressional assignment, at least where Congress has not expressly or implicitly disapproved the jurisdiction. ${ }^{432}$ But Congressman Marshall instead proposes to call in federal judges in some other capacity, because of his view that Article III courts are disabled from acting beyond a water's edge limit-of which more in a moment.

Riveting in its implications for an unchecked Executive, is Virginia Federalist Marshall's view that the judiciary may be called upon in an Article III capacity to aid implementation, yet apparently may be limited to carrying out the Executive's legal determinations. ${ }^{433}$ There was much to be said for at least

429. Virginia Federalist (Richmond, Va.), Sept. 7, 1799, at 3, col. 4; also in 4 THE PAPERS OF JOHN MARSHALL, supra note 421 , at 28.

430. Compare Durousseau v. United States, 10 U.S. (6 Cranch) 307 (1810).

431. United States v. Rob[b]ins, 27 F. Cas. at 833. The Virginia Federalist Marshall states that Judge Bee originally thought extradition "a question which exclusively belonged to the Executive, and therefore, that he, as a Judge, could not in any manner be required to aid in the execution of the treaty." But, "finding, by recurrence to the Constitution, that the Judicial power extended to Treaties, [Bee] was then satisfied that the Judges might be called on where circumstances rendered it proper, to take the necessary steps, in order to have the Treaty carried into effect, as by issuing a warrant to secure the fugitive, until the determination of the government could be known, and after that was promulgated, giving the necessary orders for carrying the determination into effect." The Virginia Federalist Marshall pronounces, "With this qualification, the opinion of the Judge was correct." Virginia Federalist (Richmond, Va.), Sept. 7, 1799, at 3, col. 4; also in 4 THE PAPERS OF JOHN MARShaLL, supra note 421 , at 28.

432.

The gentleman from Pennsylvania contends that, although this should be properly an Executive duty, yet it cannot be performed until Congress shall direct the mode of performance. He says that, although the jurisdiction of the courts is extended by the Constitution to all cases of admiralty and maritime jurisdiction, yet if the courts had been created without any express assignment of [this?] jurisdiction, they could not have taken cognizance of cases expressly allotted to them by the Constitution. The Executive, he says, can, no more than courts, supply a legislative omission.

It is not admitted that, in the case stated, courts could not have taken jurisdiction. The contrary is believed to have been the correct opinion.

10 ANNALS OF CONG., 6th Cong., 1st Sess. 614 (Mar. 7, 1800) (bracketed word added). Even without the bracketed addition, this view of the self-execution of Article III seems to go beyond Marshall's later position in Durousseau. The analogy he is drawing here is to the Presidency, and the President was expressly assigned other duties by federal legislation from which express assignment Marshall takes no negative inference.

433. See Virginia Federalist (Richmond, Va.), Sept. 7, 1799, at 3, col. 2; also in 4 THE PAPERs OF JOHN MARSHALL, supra note 421, at 28 ("giving the necess.ry orders for carrying the [government's] determina- 
an initial Presidential role, to decide whether a treaty request would be honored. The judgment of the President was necessary for the "personal safety of individuals." ${ }^{\text {"434 }}$ The judge himself had required an inquiry to the Executive before he would proceed. ${ }^{435}$ But Virginia Federalist Marshall goes beyond this to intimate that the interpretation of the treaty may belong exclusively to the Executive. Marshall repeatedly dramatizes the judiciary as an "inferior authority" and "inferior department," in contrast to the President who acts as "chief magistrate." 436 Treaty performance was a "mere question of state, and all questions relative to the affairs of the nation emphatically belong to the government to decide upon"; the judiciary was an "inferior authority" whose "subordinate officers ... do not represent the general national concerns." Marshall explains why Adams' use of the words "advise and request" is unobjectionable: "it will surely be admitted that the word 'advise' is at least as harmless as the words 'command' and 'at your peril' which are to be found in the warrant of every superior to his inferior officer throughout the United States." ${ }^{438}$ Virginia Federalist Marshall speaks of the judge as "issuing a warrant to secure the fugitive, until the determination of government could be known, and after that was promulgated, giving the necessary orders for carrying the determination into effect." ${ }^{\$ 39}$ Marshall's apparent view may be likened most plausibly to present-day political question doctrine or to assignment of matters to unreviewable administrative agency decision. ${ }^{440}$ Our modern sensibility rebels, because of our belief that a question of personal liberty should never be solely for the Executive. The seductiveness of Marshall's suggestion lies in its analogy to an Executive function more familiar to us--treaty commissioners' task of settling claims to money and property. If individual property claims can be settled by Executive determination, why not questions of personal status and liberty? Liberty always has the protection of habeas corpus, but the scope of inquiry a court will make on habeas corpus depends in turn upon its

tion into effect"). Virginia Federalist Marshall appears to doubt that the judge has to make any independent legal determination after the Executive speaks.

434. Id. at 25 .

435. "[T]he matter never was, nor could be regularly fully before the Judge, until he had received" Pickering's letter which was "handed to the counsel on both sides, plainly as the authority on which he proceeded." "Till then he had no authority to act definitively upon the question." Id. at 27.

436. Id. at $25,26$.

437. Id.

438. Id. at 27 (emphasis in original).

439. Id. at 28.

440. Virginia Federalist Marshall's argument could be understood as one of several claims: (a) Aruicle II of the Constitution assigns determinations of a certain nature to the Executive (such as setting the bounds of national jurisdiction), at least absent legislation to the contrary; (b) a treaty can assign certain determinations to the Executive, at least absent legislation to the contrary; or (c) a treaty and Article II may act in combination: the constitutional duty of faithful execution may require the Executive to act upon legal determinations when there is no jurisdiction to hear the matter in court. This last comes in two variants: (i) Article $m$ of the Constitution is self-executing, but it excludes certain matters from the courts, and hence they must be resolved by the Executive; (ii) Article III is not self-executing, legislation has failed to assign the necessary jurisdiction to the courts, and hence certain determinations must be made by the Executive. 
theory of foreign affairs power and the procedural and substantive prerequisites of due process. The Alien Act of 1798 assigned deportation of aliens exclusively to the Executive; the Chinese exclusion cases of the late nineteenth century would allow the same assignment; if this could be done by statute, why not by treaty as well? ${ }^{441}$ American courts continue to this day to regard a claim of violation of an extradition treaty as belonging solely to the signatory government, not the defendant, when a criminal defendant is brought into the United States for trial from abroad by irregular means. Only where the foreign country protests a treaty violation can the defendant raise the treaty claim as a justiciable defense, unless perhaps where there has been a gross violation of minimum standards of decency. ${ }^{442}$ In that sense the treaty provision does not create any right in the individual, unless the pertinent government chooses to raise the claim. Virginia Federalist Marshall's claim is simply the converse. If treaty rights belong to a government to raise or not in protest before the court of its treaty partner, if treaties create no rights in propria vigore in individuals brought to the United States, then how could they create any right in an individual being removed from the United States? What Marshall misses, of course, is that the right in the individual challenging removal from the United States stems from the Constitution, not the treaty alone. The only "law" by which the party can be deprived of his liberty within the United States is the treaty, and one might have thought it was the peculiar province of the judiciary to say what the law is, most surely in matters of liberty. ${ }^{443}$

Congressman Marshall proceeds initially by more modest means, by a strategy of exclusion, apparently more sensitive to the charge of improper interference with judicial function. Article III is to be taken as a strict and unforgiving text, limiting the federal judiciary to the jurisdiction plainly provided. ${ }^{44}$ By narrowly confining Article III, Congressman Marshall works to

441. See Fong Yue Ting v. United States, 149 U.S. 698, 713-14, 730-31 (1893). Five Justices of the Fuller Court concluded that the power to expel aliens could be regulated by treaty and "exercised entirely through executive officers" unless (in this age when self-executing Article III was no longer touted) Congress chose to call "in the aid of the judiciary to ascertain any contested facts" on which an alien's right to remain in the country was made to depend. "It is no new thing for the law-making power, acting either through treaties made by the President and Senate, or by the more common method of acts of Congress, to submit the decision of questions, not necessarily of judicial cognizance, . . . to the final determination of executive officers." Id. at 714. The example chosen by Justice Horace Gray to illustrate the point, so late in the nineteenth century, was Jonathan Robbins. Absent legislation to the contrary, the "surrender, pursuant to treaty stipulations, of persons residing or found in this country, and charged with crime in another, may be made by the executive authority of the President alone, when no provision has been made by treaty or by statute for an examination of the case by a judge or magistrate. Such was the case of Jonathan Robbins . ..."Id.

442. See Ker v. Illinois, 119 U.S 436 (1886); United States v. Toscanino, 500 F.2d 267, 270 (2d Cir. 1974); United States ex rel. Lujan v. Gengler, 510 F.2d 62, 67 (2d Cir.), cert. denied, 421 U.S. 1001 (1975); quaere, United States v. Noriega, No. 88-0079CR (S.D. Fla. 1988) (trial pending). But see Cook v. United States, 288 U.S. 102 (1933) (treaty limiting jurisdiction to seize British vessel enforced against libellant).

443. Still one might ask why American courts should have no interest in giving effect to the guarantees of personal liberty provided under foreign law and foreign constitutions.

444. This beginning point might attract Jeffersonians, who so greatly feared the theory of federal common law, which seemed to allow the exercise of extraordinary powers by a politicized federal judiciary, 
clear a path for the unavoidable exercise of Article II powers-or Article I/II powers, since here the President would execute a treaty whose ratification was consented to by the mediately democratic Senate. ${ }^{445}$ If a particular dispute in treaty enforcement is by its nature outside of Article III, then it must be given another constitutional domicile, such as a system of treaty commissioners or treaty tribunals.

Marshall's attempt to prove that the dispute fell outside Article III is the least successful (or may one say, salvageable) part of his House argument. It turned largely upon the executory nature of an act of delivery, and extraterritoriality. Marshall correctly pointed out that, contrary to the solecism of Livingston's motion in the House of Representatives, ${ }^{446}$ federal judicial power does not extend to "all questions" arising under the Constitution, treaties, and laws of the United States. Article III extends judicial power to "all cases in law and equity" arising under these sources of law. But then, Marshall proceeds $e x$ cathedra: Extradition is not a case. ${ }^{447}$

A case in law or equity was a term well understood, and of limited signification. It was a controversy between parties which had taken shape for judicial decision. ... To come within this description, a question must assume a legal form for forensic litigation and judicial decision. ${ }^{448}$

Marshall's excision was not so self-evident as pretended, since the committal of an extradition prisoner in many ways resembles traditional "forensic litigation." Binding-over for foreign trial does not differ functionally in the nature of the judge's task from committing for domestic trial except for the dilemma of coordinating the interpretations of a treaty by two independent branches, disposing of defenses that would not be heard by the foreign tribunal, and ultimately ceding jurisdiction of the prisoner to the foreign sovereign. But with rhetoric that claimed the inexorability of what is to follow, Marshall asserted this binding-over was quite unlike determining title to land, or setting a punishment for a crime.

A case in law or equity proper for judicial decision may arise under a treaty, where the rights of individuals acquired or secured by a treaty

\footnotetext{
displacing the function of state judicial authority in ordinary matters of police.

445. The treaty power is recognized in Article II, section 2, but the function of advice and consent to ratification evidently depends upon the character of the Senate, set out by Article I.

446. Livingston's motion of censure complained Adams had failed to heed that "the Judiciary power shall extend to all questions arising under the Constitution, laws, and treaties, of the United States." 10 ANNALS OF CoNG., 6th Cong., 1st Sess. 532-33 (Feb. 20, 1800).

447. Marshall chose to ignore the clauses of Article III, section 2, that also extend federal judicial power to "Controversies . . . between a State, or the Citizens thereof, and foreign States" and to "Controversies to which the United States shall be a Party."

448. 10 ANNALS OF CONG., 6th Cong., 1st Sess. 606 (Mar. 7, 1800).
} 
are to be asserted or defended in court. ... But the Judicial power cannot extend to political compacts; as the establishment of the boundary line between the American and British dominions; the case of the late guarantee in our Treaty with France, or the case of the delivery of a murderer under the twenty-seventh article of our present Treaty with Britain. ${ }^{449}$

We may take this as simply an inarticulate argument about lack of finality, or inability to enforce the law even-handedly between parties to the litigation. If the Executive has the power to refuse delivery regardless of the judge's decision, is the judge's opinion not merely advisory? ${ }^{450}$ What if a judge were to set conditions on the surrender-for example, in modern extradition law, a condition of "specialty" (that the surrender is made only for trial of certain crimes), or a condition that certain punishments not be inflicted. The foreign officials applying for custody will not remain within the control of the court; extraterritorial enforcement of the conditions of surrender will depend on political and diplomatic sanctions and persuasion. In what sense, then, is the matter really justiciable at all? It looks like a case insofar as it involves a probable cause determination, but it bears little resemblance to a case in the efficacy of "judgment" that follows from the finding of probable fact. But Marshall did not rest upon this.

Marshall's main defense against the suggestion of interference with Article III courts, or of improper failure to await implementing legislation from Congress, is a confabulated argument concerning a water's edge limit for federal judicial power. Marshall argues that the law of nations placed limits on United States prescriptive, adjudicative, and enforcement jurisdiction and this barred the courts from taking any part in a rendition:

What power does a court possess to seize any individual and determine that he shall be adjudged by a foreign tribunal? Surely our courts possess no such power, yet they must possess it, if this article is to be executed by the courts.

... It has already been shown that the people of the United States have no jurisdiction over offences committed on board a foreign ship against a foreign nation. Of consequence, in framing a Government for themselves, they cannot have passed this jurisdiction to that Government. ${ }^{451}$ The law, therefore, cannot act upon the case. ${ }^{452}$

449. Id. at 606-07 (Mar. 7, 1800).

450. But one might reply: the Executive has the power to cease prosecution of a domestic criminal case, yet this does not make merely advisory a judge's decision on probable cause for domestic binding-over.

451. Marshall's argument hinged on the same claim made by Wilson in his grand jury charge: the law of nations imposes a mandatory limit on American domestic law. Neither Constitutional Convention nor Congress could exceed United States prescriptive jurisdiction as set by the law of nations. No nation "has any jurisdiction at sea, but over its own citizens or vessels, or offences against itself," id. at 598, and murder by an assumedly British sailor on a British frigate was neither of these. Marshall's account of prescriptive jurisdiction was narrower than Wilson, denying Congress the right to punish foreign nationals on foreign 
So using international law as the limit on judicial jurisdiction is sleight of hand. Even assuming the flag country has exclusive prescriptive, adjudicative, and enforcement jurisdiction over the conduct of its own nationals on board its ship on the high seas, this does not forbid another country from acting in aid of that jurisdiction in ancillary proceedings, through delivery of fugitives or production of evidence. If the President can be assigned power to act, why can't a court? Marshall may have in mind a distinction similar to Locke's between the powers of domestic governance and the federative power (the power to act internationally). The former is law, the latter is politics, and courts can only act pursuant to law. But this is nominalism.

As an alternate strategy, however, Congressman Marshall makes an argument about the Presidency that is close to Hamilton's Pacificus in its generous account of the President's function, and to Virginia Federalist Marshall in its notion of political questions in treaty law. Wide awake to Marshall's penchant for lacing the drink with unannounced minor premises, we may reconstruct him as follows. The President is to decide certain issues not only by process of elimination because courts lack jurisdiction over extraterritorial crime, but by an affirmative Constitutional assignment of responsibility. It is not merely the President's abstract duty to execute the law that is key here, but his responsibility to guard the nation from harm. If a foreign nation makes a demand, and it is improperly refused, the consequences can include the threat and use of force. Certain sorts of questions cease to be justiciable because, potentially, they involve international safety. If a treaty partner has agreed to have disputes determined in a court of law, that is well and good. But if a treaty only specifies a national duty to be performed by the United States, a treaty partner is not bound to accept the adjudication of an American court, and can take retaliatory action should the United States fail to perform the international obligation. Hence the President has a duty to see that the state-to-state undertaking is carried out-it is not enough to apply to a coordinate branch for execution.

[T] he casus foederis, under the twenty-seventh article of the treaty with Great Britain, is a question of law, but of political law. The question to be decided is, whether the particular case proposed be one in which the nation has bound itself to act, and this is a question depending on principles never submitted to courts.

vessels for any crime other than piracy, even where Congress has not varied from the law of nations in defining the crime.

The statutory piracy defined by Congress' Act of April 1790, which encompassed murder and mutiny on the high seas, could not be read to include foreign actors, Marshall asserted, lest it cover a shipboard revolt that might occur during a battle between English and French ships of war. The act of indictment in New Jersey could not settle the jurisdictional question, Marshall said, sailing silently past the Charles Lee opinion. Id. at 604-605 (Mar. 7, 1800).

452. Id. at 607 (Mar. 7, 1800) (footnote added). 
The case was in its nature a national demand made upon the nation. The parties were the two nations. They cannot come into court to litigate their claims, nor can a court decide on them. Of consequence, the demand is not a case for judicial cognizance.

The President is the sole organ of the nation in its external relations, and its sole representative with foreign nations. Of consequence, the demand of a foreign nation can only be made on him.

$$
* * * *
$$

The Executive is not only the Constitutional department, but seems to be the proper department to which the power in question may most wisely and most safely be confided.

The department . . . entrusted with the whole foreign intercourse of the nation, with the negotiation of all its treaties, with the power of demanding a reciprocal performance of the article, which is accountable to the nation for the violation of its engagements with foreign nations, and for the consequences resulting from such violation, seems the proper department to be entrusted with the execution of a national contract, like that under consideration. ${ }^{453}$

Marshall rests upon the President's responsibility for the consequences of failed performance-as the department "entrusted with the whole foreign intercourse of the nation," and "accountable to the nation for the violation of its engagements with foreign nations, and for the consequences resulting from such violation." 454 In our own age, in the jurisprudence of a powerful country that has less to fear from foreign retaliatory action, the Presidency's special capacity for monitoring foreign affairs and operational responsibility for foreign policy have not sufficed to differentiate a justiciable treaty term from a nonjusticiable term. But we should not make light of the origin of Marshall's idea of "political questions" within treaty interpretation. The Supreme Court has no sword nor purse, and, in a dangerous world, no armed ranks to protect national safety. At a time when violation of the law of nations or breach of a treaty promise could give cause for war, the President's responsibility for conserving the peace could be seen as strong reason to accept Presidential determination of some treaty questions as final. Even beyond the danger of war, in our own age of great power, the unavoidable effect of any domestic construction on how a foreign partner will read its reciprocal obligation, and the rule of international law that domestic constitutional structure does not excuse failure to keep a pact,

453. Id. at 613-14 (Mar. 7, 1800).

454. Id. at 614 (Mar. 7, 1800). Finally, too, was Marshall's sense that cooperation in treaty relations required tempered policy and prudence, rather than judicial clear-cutting. Treaty relations involved questions of "political power" and a "political compact." Id. at 606 (Mar. 7, 1800). There were times when "policy may temper the strict execution of the contract."

"[W]here may that political discretion be placed so safely as in the department whose duty it is to understand precisely the state of the political intercourse and connexion between the United States and foreign nations, to understand the manner in which the particular stipulation is explained and performed by foreign nations, and to understand completely the state of the Union?" Id. at 614-15 (Mar. 7, 1800). 
could be offered to create a limited doctrine of "political questions" within treaty interpretation-reading a treaty as assigning some particular legal determinations exclusively to the President. Even when seized of a case under Article III, a court might exercise jurisdiction only to determine that the President had such an assignment of authority and, perhaps, that the limits of the assignment were not exceeded. Sensibility would be least offended by such a notion if the treaty terms assigned to the Executive were relatively distant from moral and individual concerns. Once it is conceded that crimes committed within foreign land territory are properly subject to extradition and foreign trial, does the remaining question of shipboard jurisdiction as within or without the treaty have any important connection to norms of fairness? Isn't this the kind of arbitrary determination that should be settled by considerations of convenience and comity-albeit handled consistently? ${ }^{455}$

Marshall's preference for Executive interpretation of treaty terms seems least troubling if we can conceive of some treaties that are not intended to create rights in the individual. ${ }^{456}$ Rather, the treaty exists as a compact between countries. It happens by unique operation of Article VI to be incorporated into domestic law as well, but is intended to have as its beneficiaries the nation as a whole rather than individuals immediately affected by its operation. But in the Robbins case, the individual's enjoyments did not exist by virtue of the treaty. Marshall's Cardozean slide and shuffle is to suggest that a treaty could serve as the basis for de jure action against the common law and constitutional entitlements of an individual, with arrest and loss of liberty, and yet be outside the law that a court could construe. The Supreme Court has abided this possibility in regard to actions against property, and against aliens, at least where it is the Congress delegating authority to the Executive, ${ }^{457}$ but the rub here was its application against a citizen's liberty without any assent by the House.

By Congressman Marshall's lights, one might ask with renewed wonder why Judge Bee was involved at all, since Article III stopped at water's edge, and political questions were for the Executive. To Marshall, it may have been activity out of doors. Marshall (as we know by his personal example) did not hold that Article III judges had to remain in a social sacristy, removed from all other works. In a young Republic, where the size of the judicial task was not yet sketched, and where court was held only at settled terms in the year, it may have been less dissonant to conceive of Article III as a part-time office, and to conclude that persons who happen to be judges might serve also as treaty commissioners or aides to the exercise of Executive power. ${ }^{458}$ We may

455. One's reaction is more heated if it were proposed to allow the Executive to determine what constituted "murder" under the treaty-whether, for example, resisting impressment was a legal defense. 456. Id, at 606 (Mar. 7, 1800).

457. See Murray's Lessee v. Hoboken Land \& Improvement Co., 59 U.S. (18 Wall.) 272 (1855); Fong Yue Ting v. United States, 149 U.S. 698 (1893).

458. Even forty years after Jay, Ellsworth, and Marshall, when Secretary of State Daniel Webster 
conclude that, just as some still believed in a federal common law of crimes that could protect the vital functions of federal governance, so there was to be an out-of-school federal magistracy to act as ministerial auxiliary to constitutional Executive functions. In an older distinction between courts and judges (familiar when a district judge and Supreme Court Justice each sat in at least two capacities), Marshall's claim may be that the judiciary can act as judges but not as courts in execution of decisions that are constitutionally committed to the Executive. ${ }^{459}$ Extraterritoriality and the public consequences of failed performance would forbid inquiry into the merits of the treaty law questions, but a judge would be permitted the ancillary function of finding facts in execution of the Executive's jurisdictional determinations. As Marshall so oddly puts it, the Executive acts "independent of judicial aid, which may, perhaps, in some instances, be called in."

Marshall attempted to buffer these views of the Executive power by supposing that it may reduce to a question of action in the first instance. The question of liberty might be inquired into on habeas corpus. With italics supplied by the astonished twentieth century reader, Congressman Marshall noted, "[I]f the President should cause to be arrested under the treaty an individual who was so circumstanced as not to be properly the object of such an arrest, he may perhaps bring the question of the legality of his arrest before a judge, by a writ of habeas corpus." 461 In the House debate, this may have been a philosophical parry for the Federalists, but it was unconvincing on the facts, if only because Judge Bee was entertaining a writ of habeas corpus in hearing argument on July $25,1799,462$ and Lieutenant Jump's quick dispatch prevented application for habeas corpus to any other judge. The effect of inquiry on habeas corpus must also depend upon what view a judge takes of Executive power to execute and interpret treaty terms.

Rightly or wrongly, Marshall claimed that the execution of the Treaty was properly consigned to the Executive, at least in the absence of implementing

wished to draft a new extradition article with the British, he called upon Justice Story for aid in his drafting. Story sent Webster a "sketch of three Articles" on "fugitives from Justice" using "the [2]7th Article of Jay's Treaty" as his guide; Webster thanked Story for the drafts, "of great use to me, and come in exact season." See Letter from Joseph Story to Daniel Webster (Apr. 19, 1842) (emphasis omitted), and Letter from Daniel Webster to Joseph Story (Apr. 25, 1842), in 1 THE PAPERS OF DANIEL WEBSTER: DIPLOMATIC PAPERS 537, 538, 542-43 (K. Shewmaker, C. Wiltse \& H. Moser eds. 1983). Justice John Marshall Harlan the senior was appointed an Arbitrator by President Harrison in the Behring Sea Fur-Seal Arbitration and missed part of the 1892 Term, see 149 U.S. iii n.l (1893), and Justice Robert Jackson served two years as Nuremberg prosecutor. One only marvels that Arthur Goldberg felt compelled to resign from the Court before his United Nations service. But see infra note 489.

459. By Article III, the judicial power of the United States is vested in courts, not judges.

460. 10 ANNALS OF CONG., 6th Cong., 1st Sess. 615 (Mar. 7, 1800) (emphasis added).

461. Id.

462. Robbins was produced in court by a writ of habeas corpus in order to entertain a motion by the British consul for his turn-over; in initiating the proceeding for the turn-over by habeas corpus, Judge Bee was at least initially wearing a judicial hat and in his own estimate, he kept on this chapeau throughout. Decision of the British motion, in the face of defense objection, squarely raised the issue of the treaty's scope. 
legislation. In his willful geometer's fashion, who boldly pronounces the theorem as proved and waits for the student to acknowledge self-evidence, Marshall concluded:

It is then demonstrated, that, according to the principles of the American Government, the question whether the nation has or has not bound itself to deliver up any individual, charged with having committed murder or forgery within the jurisdiction of Britain, is a question the power to decide which rests alone with the Executive department. ${ }^{463}$

Marshall is sketching a potentially radical refocusing of constitutional power-permitting the Executive and treaty power magistracy to make legal determinations and to affect the dearest of domestic entitlements, to detain persons who may happen to be citizens and deliver them into the custody of foreign governments. If one took this truncated view of Article III powers, and allowed some sort of moonlighting magistracy to act in execution of Executive determinations, without any implementing statute or jurisdictional legislation, Congress' control of the Executive would seem much more fragile.

Marshall's view may be cabined as a bluff, designed to persuade a House of Representatives jealous of the treaty power that declining to pass implementing legislation would only enhance Executive power. But his extended praise of the virtues of Executive decision makes it hard to rest with this view. It is striking that Marshall did not defend Adams on the narrower facts of his involvement, spurning the possible argument that Adams' "advice and request" was only precatory, a litigant's motion. Rather, Marshall defends a Presidential role as conceived by Pickering and Hamilton-with treaty determinations to be made by the President and merely carried out by the judge. As in Holmes' excesses in Missouri $v$. Holland ${ }^{464}$ there is the suggestion that perhaps foreign affairs power is not constrained by the ordinary rules of domestic constitutional law.

Modern critics of Executive power have paid little heed to this John Marshall. It is clear that Marshall had a far more radical theory of Executive power than is realized by these contemporary writers. Marshall's view of the Presidency as "the sole organ of the nation in its external relations"465 was not just a statement about passing along diplomatic messages, as Professors Edward

463. Id. at 615 (Mar. 7, 1800).

464. 252 U.S. 416 (1920). The eternal puzzle of Missouri v. Holland is, of course, why Holmes went out of his way to intimate that treaty power is not limited by the Constitution's ordinary rules of federalism. Holmes could have demurely placed controls on migratory birds within regulation of interstate and foreign commerce, and then decided only that treaty power extends at least as far as Congress' enumerated legislative powers.

465. 10 ANNALS OF CONG., 6th Cong. 1st Sess. 613 (Mar. 7, 1800). For the full passage, see supra pp. 347-348. 
Corwin, Leonard Levy, and Harold Koh have mistakenly suggested. ${ }^{466}$ And this, in turn, may render Justice Sutherland's modern reiteration of Marshall's position in United States v. Curtiss-Wright Export Corp. ${ }^{467}$ a more radical opinion as well.

The immediate question that remained in the 1800 political controversy was how young Budd could have been saved from Vere's decision. Marshall, who was later to be called trimmer between Federalists and Republicans, did his best to side-step the claim that only directly elected or participatory organs of government could give proper weight to revolutionary principles. In Marshall's argument we may see the partial victory of a Republicanized common law, though not a Republican decision structure. Marshall argued implicitly that it did not require a jury, or grand jury, or the House of Representatives to properly credit the right of resistance against tyranny. Rather, a President, judge, or treaty commissioner would have the same ends. Judge Bee's proper performance of the duties delegated to him by the President should have resolved the case rightly. The mishap, if any, occurred because of technical mistake. The opinion given by the President had been predicated on the seaman's apparent British citizenship, and "if a new circumstance occurred, which would essentially change the case decided by the President, the Judge ought not to have acted under that decision, but the new circumstance ought to have been stated."468 Animus furandi was central. Judge Bee was asked to pass on the sufficiency of evidence, ${ }^{469}$ and the question of sufficiency must be tested against a reformed common law. An impressed American seaman making his escape could not be bound over for trial as a murderer because he lacked guilty intention. Marshall took a substantive view of lawful resistance closer to the Aurora than to Peter Porcupine:

466. See E. CORWIN, THE PRESIDENT: OFFICE AND POWERS, 1787-1984, at 178 (4th ed. 1957) (“Clearly what Marshall had foremost in mind was simply the President's role as instrument of communication with other governments.") (emphasis in original); L. LEVY, ORIGINAL INTENT AND THE FRAMERS' CONSTITUTION 52 (1988) ("John Marshall's 1800 declaration ... meant nothing more than that only the President communicates with foreign nations; he is the organ of communication."); $\mathrm{H} . \mathrm{KOH}$, THE NATIONAL SECURTY CONSTITUTION: SHARING POWER AFTER THE IRAN-CONTRA AFFAIR 81 (1990) ("when Congressman (later Chief Justice) John Marshall rose on the floor of the House in 1800 to call the president 'the sole organ of the nation in its external relations,' his remarks were uncontroversial, not because Congress had accepted a broad presidential monopoly over all foreign relations, but because it had largely acquiesced in the president's narrower dominance over diplomatic communications.").

467. 299 U.S. 304 (1936). Curtiss-Wright addressed Congress' delegation to the President of power to limit the export of arms; the breadth of the delegation was sustained in light of the President's inherent authority in foreign affairs. The subtext of Curtiss-Wright is loud and clear, at least in a Federalist reading: it cannot be unconstitutional to delegate to the President an authority he may already possess. See also United States v. Pink, 315 U.S. 203, 229-30 (1942); Youngstown Sheet \& Tube Co. v. Sawyer [The Steel Seizure Case], 343 U.S. 579, 684-85, 702 (1952) (Vinson, C.J., dissenting).

468. 10 ANNALS OF CoNG., 6th Cong., 1st Sess. 617 (Mar. 7, 1800).

469. The President had "directed Thomas Nash to be delivered to the British Minister, if satisfactory evidence of the murder should be adduced. The sufficiency of the evidence was submitted entirely to the Judge." Id. 
Had Thomas Nash been an impressed American, the homicide on board the Hermione would, most certainly, not have been a murder.

The act of impressing an American is an act of lawless violence. The confinement on board a vessel is a continuation of the violence, and an additional outrage. Death committed within the United States, in resisting such violence, would not have been murder, and the person giving the wound could not have been treated as a murderer. Thomas Nash was only to have been delivered up to justice on such evidence as, had the fact been committed within the United States, would have been sufficient to have induced his commitment and trial for murder. Of consequence, the decision of the President was so expressed as to exclude the case of an impressed American liberating himself by homicide. ${ }^{470}$

Thus a theory of political resistance was to be introduced by choice of law, governing the relations on board a British ship by American rules against impressment. For treaty purposes, impressing an American was "an act of lawless violence," even though impressment might be allowable under British law.

This knitting of natural rights within the fabric of American common law, to legalize revolution by technical elements of animus furandi is, if you like, what ensnarled District Judge Thomas Bee. In a common law system, arrest and binding-over for trial does not ordinarily involve a hearing of all the evidence; both parties are present, but full investigation of possible defenses is saved for the occasion of trial. The standard of evidence sufficient for binding-over is merely probable cause. But with substantially conflicting legal systems, the problems are obviously different. On the issue of a natural law or American common law right of resistance against impressment, the Charleston hearing was all the trial there ever would be. Certainly no drumhead courtmartial in Jamaica was likely to recognize a claim of justifiable homicide to escape impressment, or the necessary lack of mens rea or animus furandi in an escape attempt. Bee was Robbins' only recourse if truly Robbins was another furious Liberty Boy "commit[ting] homicide for the purpose of liberating himself from the vessel in which he was confined."471 Hence, a full hearing by the standards necessary for conviction should have been supplied if the defense was to be available. And since the hearing had to be held in America, why then should not the ordinary finders of fact in criminal matters-the jury - have sway? In framing a natural rights defense wholly within the speech of the common law, perhaps Marshall, like Bee, failed to understand how ordinary procedures could not suffice. A more defiant sense of the difference in American law may have been necessary to warn against the inadequacy of ordinary procedure, and a new legal rhetoric needed to summon resistance.

471. Id. 


\section{THE ELECTION OF 1800}

The House debate did not close the issue for John Adams and the Republicans. The familial historian of the Adams administration reports a canard that Marshall's speech quieted all opposition. Henry Adams, great-grandson of President John, wrote that Albert Gallatin was asked by House Republicans to make a reply, and according to a "tradition in Virginia," Gallatin muttered "answer it yourselves." 472 Henry Adams thought the story "probably true."473 But Gallatin's own papers show what appear to be running notes of Marshall's speech, and several points of rebuttal in the right hand margin. The Republicans' motion to censure Adams was defeated by 61 to 35, the day after Marshall's speech, ${ }^{474}$ but the House vote is not easily interpreted as embrace of Marshall's theory; on March 6, sitting as a Committee of the Whole, the day before Marshall spoke, the House had already voted down the Republican motion of censure by a similar margin. ${ }^{475}$ Marshall did not persuade the House that Adams deserved any vote of confidence; Bayard's motion of approbation was laid aside rather than put to test. ${ }^{476}$

Marshall's House speech did not persuade Jefferson. On a copy of the speech printed in pamphlet form, Jefferson wrote in continued dissent:

1. It was Pyracy by the law of nations, \& therefore cognisable by our courts. 2. if alleged to be a murder also, then whether he was an impressed American was an essential enquiry. 3. tho' the President as a party subordinate to the court might enter a Nolle pros, a requisition in the style of a Superior was a violation of the Constitutional independancy of the Judiciary. ${ }^{47}$

472. HENRY ADAMS, THE LIFE OF GALLATIN 232 (1880) (emphasis omitted); see also JOSEPH STORY, A DISCOURSE UPON THE HONORABLE JOHN MARSHALL, AT THE REQUEST OF THE SUFFOLK BAR 44 (Boston 1835) (Marshall's speech "placed him at once in the first rank of constitutional statesmen. . . . as was said of Lord Mansfield's celebrated Answer to the Prussian Memorial, it was Reponse sans replique . . . . It silenced opposition, and settled then, and for ever, the points of national law upon which the controversy hinged.").

473. HENRY ADAMS, THE LIFE OF GALLATIN, supra note 472, at 232.

474. 10 ANNALS OF CoNG., 6th Cong., 1st Sess. 619 (Mar. 8, 1800).

475. The vote was 58 to 34. Id. at 595 (Mar. 6, 1800). Albert Beveridge's account is thus misleading at best. See 2 A. BEVERIDGE, supra note 238, at 473 ("Marshall's argument was conciusive. It is one of the few speeches ever delivered in Congress that actually changed votes from one party to the other in a straight-out party fight.").

476. 10 ANNALS OF CONG., 6th Cong. 1st Sess. 621 (Mar. 10, 1800). Bayard's resolution was not "strongly adopted"; 4 THE PAPERS OF JOHN MARSHALL, supra note 421, at 36, is mistaken in the point.

477. Handwritten inscription by Jefferson on verso of last page of printed pamphlet SPEECH OF HON. JOHN MARSHALL, DELIVERED IN THE HOUSE OF REPRESENTATIVES OF THE UNITED STATES ON THE RESOLUTIONS OF THE HON. EDWARD LIVINGSTON, RELATIVE TO THOMAS NASH, ALIAS JONATHAN ROBBINS (Virginia Historical Society, Political Pamphlets, I, no. 7), in 4 THE PAPERS OF JOHN MARSHALL, supra note 421, at 109 n.1. (Jefferson's inscription includes the crossed-out phrases "he could not countrol the court as" and "by requisition"). Jefferson credited Marshall's skill, nonetheless, remarking that "Livingston, Nicholas, \& Gallatin distinguished themselves on one side, \& J. Marshall greatly on the other." Letter from Thomas Jefferson to James Madison (Mar. 4, 1800), in 7 THE WRITINGS OF THOMAS JEFFERSON, supra note 18 , at 432 . 
Other Republican voices were not lacking during or after the House debate. It was intimated that British Minister Robert Liston had been skulking about the Congress and perhaps influenced the proceedings. "Private whispers, words, and blinks, to the members, excite suspicion, and give occasion for remarks about secret service money... . Is it proper that a minister of a foreign nation should evidence such consummate familiarity with American legislators?" asked the Philadelphia Aurora. ${ }^{478}$ The Aurora made mock of the Federalists for introducing a copy of the British extradition statute during the House proceedings: it showed that the monocratic President presumed more power even than would the English throne; "the President did what that king could not do without an act of parliament." 479 The call for legislation to regulate the Executive's use of the extradition article was still heard. Said the Virginia Argus, "It is highly necessary that a law should be passed, elucidating the article of the British treaty, and establishing a construction of it, consistent to the immutable rights of Americans." ${ }^{480}$ Marshall's speech was deemed "ingenious and specious" ${ }^{\prime 81}$ in its defense of the Executive's part in the proceeding, though the Aurora took great comfort from Marshall's agreement that an impressed American sailor could legitimately use violence to escape from his captivity.

The animus of Republican newspaper comment did begin to change, leaving off direct attack on Adams' intention in the Robbins affair and focusing instead on Pickering as the counsellor who misled the prince. ${ }^{482}$ The Aurora worried

478. Aurora (Philadelphia, Pa.), Mar. 8, 1800, at 2, col. 1 (emphasis in original).

479. Duane cackled:

How unlucky for Mr. Bayard that he proved two things instead of one-that he should have proved by one and the same instrument, that the British king, in the plenitude of all his power, required a law of parliament to direct him in the execution of this article, and that the President of the United States should assume to himself a power of carrying it into effect, not by a law of Congress, but by a law of his own! No one will say that the powers of the President are constitutionally equal to the powers of the king of Great Britain, and yet we see, that the President did what that king could not do without an act of parliament _-

Id. (emphasis in original).

480. Argus (Richmond, Va.), reprinted in Aurora (Philadelphia, Pa.), Mar. 6, 1800, at 2, col. 2. Said the Albany Register, reprinted in Aurora (Philadelphia, $\mathrm{Pa}$ ), Mar. 14, 1800, at 2, col. 4:

The Judiciary have the sole power of deciding in the first instance on all cases arising under treaties as laws of the land. But suppose from the peculiar nature of a case, the occurrence of such doubts respecting the construction and application of a treaty clause, as the Judiciary could not of themselves remove; it would then become their duty to apply to Congress for a declaratory law on the subject.

481. Aurora (Philadelphia, Pa.), Mar. 10, 1800, at 2, col. 1 (emphasis omitted).

482. "Pickering's letter [was sent] to Judge Bee, in the name of the President, but without his privity or knowledge," deflected the Aurora, May 23, 1800, at 2, col. 2. "Mr. Adams is said to have denied that he had authorized this letter dictating to the judiciary which would be a violation of the constitution," a later report mildly jibed. Id., Aug. 22, 1800, at 2, col. 3; also in Virginia Argus (Richmond, Va.), Sept. 2, 1800 , at 3 , col. 2 .

Meanwhile, Pickering attempted to wrap himself in Marshall's speech, claiming his own prior authorship of a theory of lawful resistance against impressment, and blaming Judge Bee for what had misfired. See Letter of Timothy Pickering to James Winchester [District Judge of Maryland] (Mar. 17, 1800) (emphasis in original), in PICKERING PAPERS, supra note 157, roll 13, at 281:

I never received an official statement of the proceedings in the case of Nash. I take it that he was committed, on the complaint of the British consul at Charleston, for mutiny and murder 
aloud that Marshall's speech "made in the minds of some people, a very satisfactory defence of the conduct of the President and Judge Bee." 483 Pickering was removed from the Cabinet on May 10, 1800, but Adams was, at the least, still deemed guilty of negligence in failing to restrain Pickering's acts. ${ }^{484}$ Adverse comment continued from another self-inflicted wound of the Federalists; in spring 1800 two editors were indicted for seditious libel of the President. The Scottish editor James Callender was prosecuted in Richmond for, inter alia, calling Adams a "man whose hands are reeking with the blood of the poor friendless Connecticut sailor." Callender's trial arrayed the prominent Republican bar of Virginia against the cram-down power of Justice Samuel Chase, with attendant publicity. ${ }^{485}$ Republican editor Thomas Cooper's comment on the Jonathan Robbins case to readers of the Sudbury and Northumberland Gazette, reprinted in the Aurora ${ }^{486}$ also received wide attention upon his trial at Philadelphia before Chase. ${ }^{487}$ In a burst of overkill, Chase instructed the Cooper jury that John Marshall's account of Executive power was true as a matter of law. ${ }^{488}$ As Senator from South Carolina, Charles Pinckney also

\footnotetext{
perpetrated on board the Hermione British frigate. - In a luminous speech, Mr. Marshall has endeavored to show, and I believe he has shown, that mutiny \& murder, or any other offence than piracy under the law of nations, committed on the high seas, in a foreign ship, are not punishable in the United States. The expression any person, in several sections of the Act of Congress for the punishment of certain crimes (passed April 30, 1790) he considered as applicable only to the people of the U.States. But [Marshall] averred the opinion, that American citizens impressed by the British ships, and committing the offenses in question, in the act of regaining their liberty, ought not to be delivered up under the 27th article of the British treaty. If this opinion be correct ['tis' one I had long ago expressed repeatedly to $\mathrm{Mr}$. Liston] was not an enquiry into the national character of Nash pertinent, on the return of the Habeas Corpus? Had there been any ground to believe him an American, I presume no order or advice for his delivery up would have been given by the Executive.
}

483. Aurora (Philadelphia, Pa), Apr. 22, 1800, at 2, col. 5. Adams' gentler treatment by Republican voices likely also followed from the attacks upon him by the High Federalists for firing Pickering in May 1800 and for his restraint toward France. Adams' renewed diplomatic mission sailed to France in late 1799. A new treaty was signed with France on September 30, 1800. See Convention of Peace, Commerce, and Navigation, United States-France, 8 Stat. 178, T.S. No. 85 (ratified Feb. 18, 1801; proclaimed Dec. 21, 1801).

484. See Aurora (Philadelphia, Pa.), Aug. 8, 1800, at 2, col. 2 ("The president of the United States, his salary is 25,000 constitutional dollars a year, for which he is sworn to discharge the duties of his office faithfully. Last year he spent nearly nine months snug in Braintree, leaving to his good man Timothy, the fate of Jonathan Robbins ....") (emphasis in original).

485. See United States v. Callender, 25 F. Cas. 239 (C.C.D. Va. 1800) (No. 14,709); J. SMITH, supra note 205, at 334-58; J. MilleR, supra note 205, at 211-20.

486. Aurora (Philadelphia, Pa.), Nov. 19, 1799, at 2, col. 5, and at 3, col. 1. Cooper had balladed the melancholy case of Jonathan Robbins, a native citizen of America, forcibly impressed by the British, and delivered up, with the advice of Mr. Adams, to the mock trial of a British courtmartial, [which] had not [at an earlier date] yet astonished the republican citizens of this free country. A case too little known, but of which the people ought to be fully apprised before the election, and they shall be.

487. See United States v. Cooper, 25 F. Cas. 631 (C.C.D. Pa. 1800) (No. 14,865); J. SMITH, supra note 205, at 307-33; J. MILLER, supra note 205, at 203-10; D. MALONE, THE PUBLIC LIFE OF THOMAS COOPER, 1793-1839, at 120-36 (1926).

488. United States v. Cooper, 25 F. Cas. at 641-42. Chase's verbal abuse of counsel at the trial was later made an article of Chase's impeachment. See Articles of Impeachment, REPORT OF THE TRIAL OF THE HON. SAMUEL CHASE, ONE OF THE ASSOCIATE JUSTICES OF THE SUPREME COURT OF THE UNITED STATES, 
provided a continuing reminder of the Robbins affair in his proposal to forbid federal judges from accepting appointment to any other federal or state office. ${ }^{489}$

Federalist thetoric hailed the 1800 elections in changing tones, by turn confident, disdainful, and resigned. On March 16, 1800, John Marshall wrote privately, with optimism, that the "violent effort" in Congress to criminate Adams' conduct in the Robbins affair "was for the purpose principally of affecting the next election of President, but I believe it has completely faild of its object." ${ }^{\text {"49 }}$ Marshall put "the chances ... more than two to one in favor of the re-election of Mr. Adams." ${ }^{\prime 41}$ The Federalist New Jersey Gazette coruscated "disorganizers of the federal government" who saw "The important election of President and Vice-President ... near at hand," the "Democratic Vampires" who hoped to "damn[ ] the reputation of the Executive." 492 "[E]nemies of your country" "have erected Telegraphs (or that which answers the same purpose, republican newspapers,)" warned the Salem Gazette. ${ }^{493}$ Reprinting Marshall's House speech, the Salem editors railed that "Of all the measures of Jacobinism ... none . . . appeared more promising or better calculated to act with force upon the feelings of the people, than the affair of Nash the pirate. TRUTH and JUSTICE . . . ever superior to the mean arts of the foul-mouthed monster, Calumny, have crushed this illegitimate offspring in its cradle." ${ }^{494}$

BEFORE THE HIGH COURT OF IMPEACHMENT 9-10 (Baltimore, Charles Evans reporter, 1805).

489. Pinckney originally proposed this ban on riding two horses as a Constitutional amendment, then recast it as a statutory amendment to the 1789 Judiciary Act. Skirting the edges of life tenure and Article III, Pinckney's statute provided that a judge's acceptance of another office "shall vacate his appointment as a Judge of the United States." The bill was defeated in the Senate by a vote of 14 to 12 on April 3, 1800. See 10 ANnals of Cong., 6th Cong., 1st Sess. 41, 67, 95, 150 (Feb. 3, Mar. 4, 5, Apr. 3, 1800); Aurora (Philadelphia, Pa), Jan. 4, 1800, at 2, col. 2; Mar. 18, 1800, at 2, col. 2; June 16, 1800, at 2-3; June 18, 1800 , at 2 , col. 3 . The text of Pinckney's statute is available among the few papers of the Sixth Congress to survive the British burning of the Capitol in 1814. See National Archives Record Group SEN 6A-B1 (S. 64). The text is also reproduced with slight variations in the June 16,1800 Aurora.

490. Letter of Congressman John Marshall to Reuben George (Mar. 16, 1800), in 4 THE PAPERS OF JOHN MARSHALL, supra note 421, at 114-15. See also Letter of Virginia Congressman Leven Powell to Major Burr Powell (Mar. 5, 1800), in 1 JOHN P. BRANCH HISTORICAL PAPERS OF RANDOLPH-MACON CoLlEge 237, 238 (1907) ("We are yet employed with the business of Jonathan Robbins . . . the object of the thing is so plain that those who Run may Read." "[I]t [has] produced a Cry out of doors that [House Republicans arel canvassing for the Election of Mr. Jefferson at the expense of $\$ 1000$ per day to our Constituents.").

491. Letter of Congressman John Marshall to Reuben George (Mar. 16, 1800), in 4 THE PAPERS OF JOHN MARSHALL, supra note 421, at 114-15. Marshall's private view of the underlying merits of the Robbins case was unequivocal: "The case really was that he was an irishman who had committed a horrid murder on board a british frigate for which he was given up. After he had been several months in prison he was induced to declare himself an American seaman in the hope that this untruth would save him." Id. at 114.

492. The Federalist New Jersey Gazette (Trenton, N.J.), Mar. 17, 1800, at 2-3 (reprinting article from Salem Gazette). The "base miscreants" represented "that we were not safe in our own doors; that we were liable to be tom from our wives and children, to be sent away, like 'poor Robbins,' and hung in chains, to satiate the savage revenge of the British! ... [The people had] been led to believe that their liberty was not safe in the hands in which it was entrusted." Id.

493. Salem Gazette (Salem, Mass.), Mar. 18, 1800, at 3, cols. 2-3 (emphasis in original).

494. Id., May 6, 1800, at 1, col. 2 (emphasis in original). 
The Philadelphia Gazette and Universal Daily Advertiser pursued a spiritualist theme, mocking "The Grand Conjuror of the House of Representatives, with his puppets, [who] have labored hard to call up the spirit of poor Nash from the 'vasty deep,' in order to secure his vote at the next election for Electors. It is thought, however, that . . . the election of Mr. Jefferson will, in future, be conducted without any spiritual aid."495 Republicans had deserted the House "since the appearance of the Castle Spectre-the frequent hauntings by Robbins' ghost having already reduced their forms to mere shadows."496

Federalist confidence dissolved at the New York elections. On May 6, 1800, the Philadelphia Gazette dolefully reported that a British frigate had arrived in New York harbor on the day of the state legislative elections, a balloting that would effectively determine New York's vote for President.

Of the people of New-York at least three fourths were decided Federalists, until, on the very day of the Election the unfortunate arrival of a British frigate in our harbour gave an opportunity to the Jacobins to circulate with success the most atrocious falsehoods. A number of men in the habit of sailors were paraded through every street \& alley, proclaiming, as they passed, that they had recently escaped from British press-gangs, and from on board the British frigate then at the watering place-that in consequence of new orders from England . . . all our seamen [are] to be subject to impressment .... .

These, and a thousand other lies gained belief among the too credulous citizens, and effectively turned the election. ${ }^{497}$

The Philadelphia Gazette was moved enough by the event to print another full page defense of Adams' conduct, ${ }^{498}$ abandoning spectral humor.

In April 1800, the House engaged in further brief debate on how to confine the Jay Treaty for any future case. Virginia Republican John Nicholas proposed to "preserve inviolable the Constitutional right of trial by jury" by barring the delivery of "any person for offences, for the trial of which any Courts of the

495. Philadelphia Gazette and Universal Daily Advertiser (Philadelphia, Pa.), Mar. 10, 1800, at 3, col. 3 (emphasis in original).

496. Id., Apr. 12, 1800, at 3, col. 3. Fenno supplemented the record with poesie for "Nash's Ghost," in the Gazette of the United States (Philadelphia, Pa.), Mar. 27, 1800, at 2, col. 4 (emphasis in original) ("Listen to my aweful story / (I'm the murderer Nash, he cries) / Fool, that think'st to purchase glory / By impeachment of the wise" "But soft, I scent the gales of morning! / Tin Gallat, Blinkynie and Ned, / Pray heed, betimes, my earnest warning / Ere you, like me, hang by the head! // From your own crimes seek ablution / Aim not at your country's life; / Prophane no more the Constitution, / Cease to foment civil strife.").

497. Philadelphia Gazette and Universal Daily Advertiser (Philadelphia, Pa), May 6, 1800, at 3, col. 3 (emphasis in original); also in Gazette of the United States (Philadelphia, Pa.), May 16, 1800, at 2, col. 5. John Fenno's paper gloomed that "the Republican faction have carried every point at New York." The "result gives a dead majority to the Republicans in the State Legislature; and ascertains the election of Mr. Jefferson to the Presidency...." Gazette of the United States (Philadelphia, Pa.), May 5, 1800, at 3, col. 1.

498. See Considerations on the Case of Thomas Nash, falsely called Jonathan Robbins, Philadelphia Gazette and Universal Daily Advertiser (Philadelphin. Pa.), May 13, 1800, at 2, cols. 2-4. 
United States are competent." ${ }^{3499}$ Nicholas fell short, 42 to $45 .^{500}$ Congressman Marshall, flirting again with his theory of political questions within the treaty power, proposed that the House should recognize in the President the power to make jurisdictional determinations, intimating that the President's decision should be a sufficient condition for foreign delivery of an offender. ${ }^{51}$ Marshall's proposal was allowed to linger and die, too strong even for a Federalist Congress. ${ }^{502}$

Republican newspapers continued their attack on Adams for his philosophical unsuitability. The Republican Virginia Argus addressed itself "To THE ELECTORS OF THE UNITED STATES" offering "brief and dispassionate reasons; why the President Adams should not be re-elected." Reason V followed: "No man is fit for a president who either wilfully or ignorantly encroaches upon the constitutional authority of the other branches of the government" which "Mr. Adams has done ... in the case of Jonathan Robbins." The public should "prefer some candidate more decisively republican in his principles and con-

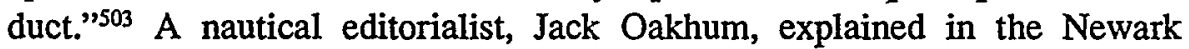

499. 10 ANNals of CONG., 6th Cong., Ist Sess. 654-55 (Apr. 2, 1800). Nicholas also proposed that any person arrested under the Jay Treaty should be able to defend against delivery on the ground that he was "an American and impressed into the British service," and should "be able to send for testimony to prove the facts of his claim"; a defendant was to be discharged "if it should appear he was impressed and kept on board a British ship, contrary to his desire." Id. See MR. NICHOLAS's MOTION, FOR AMENDING THE BILL TO PROVIDE FOR THE EXECUTION OF THE 27TH ARTICLE OF THE TREATY OF AMTTY, COMMERCE, AND NAVIGATION WTTH GREAT BRTAIN (Philadelphia 1800), available in EARLY AMERICAN IMPRINTS, 16391800, supra note 116 (Evans No. 38793).

500. 10 ANNALS OF CONG., 6th Cong., 1st Sess. 691 (Apr. 28, 1800). See Philadelphia Gazette (Philadelphia, $\mathrm{Pa}$ ), Apr. 29, 1800, at 2, cols. 2-3 ("it was contended on one side, that this House had no right to put a construction on the treaty; and on the other, that no treaty could deprive a man of the right of trial by jury, nor wrest from our courts the absolute Jurisdiction given by the constitution").

501. Marshall proposed that upon any Treaty request, "testimony should be taken in writing and transmitted to the Secretary of State, and by him laid before the President of United States, whose opinion should decide whether the matter was cognizable in any court of the United States or whether the offender should be delivered up." 10 ANNALS OF CONG., 6th Cong., 1st Sess. 654 (Apr. 2, 1800) (emphasis added). See also Philadelphia Gazette (Philadelphia, Pa), Apr. 3, 1800, at 2, col. 3. The original text of Marshall's BILL TO PROVIDE FOR THE EXECUTION OF THE TWENTY-SEVENTH ARTICLE OF THE TREATY OF AMITY, COMMERCE, AND NAVIGATION WITH GREAT BRTAIN (Philadelphia 1800), is available in EARLY AMERICAN IMPRINTS, 1639-1800, supra note 116, indexed in R.P. BRISTOL, SUPPLEMENT TO CHARLES EVANS' BIBLIOGRAPHY (1970) (Bristol No. B11154, mictoprint 49158); also in 4 THE PAPERS OF JOHN MARSHALL, supra note 421 , at 120 .

502. See 10 ANNALS OF CoNG., 6th Cong., 1st Sess. 691 (Apr. 29, 1800). Marshall also moved to limit the number of witnesses a judge had to call on behalf of a prisoner to explore a claim of impressment; an English agent would be allowed to adduce "counter testimony" disputing a fugitive's claim of American citizenship and impressment. See MR. NICHOLAS'S MOTION FOR AMENDING THE BILL TO PROVIDE FOR THE EXECUTION OF THE TWENTY-SEVENTH ARTICLE [WITH THE AMENDMENTS OF MR. MARSHALL THERETO] (Philadelphia 1800), available in EARLY AMERICAN IMPRINTS, 1639-1800, supra note 116 (Evans No. 38794). Marshall's amendments were "somewhat opposed," and the bill went no further. See 10 ANNALS OF CoNG., 6th Cong., 1st Sess. 691 (Apr. 29, 1800).

503. Virginia Argus (Richmond, Va.), Mar. 18, 1800, at 3, cols. 1-4. "What are the fruits of JoHN ADAMS' Administration?" asked the Virginia Argus on April 22. The answer was clear: a standing army, direct tax, alien and sedition laws, four million dollars or more for a navy, and, to boot, "He has given orders to one of our judges to deliver up Jonathan Robbins . . . in direct contradiction to the laws of nations, and of our constitution." Id., Apr. 22, 1800, at 3, col. 2 (emphasis in original). 
Centinel of Freedom, why he would not vote for Adams. "[T] he crew of the Federal ship will shortly be piped on deck to choose a commander for the next quadrennial voyage," but Jack Oakhum "would not [be] holding up my hand for John Adams, our present commander" who "suffered an enemy to board us, press part of our hands, and rob us of our provisions, insult our flag, and abuse the crew, without even remonstrating with the captain of the enemy, or shewing any resentment." ${ }^{.504}$ In October 1800, as the choice of Presidential electors came immediately to hand, Philip Freneau, as Robert Slender, appeared once again in the Aurora to remind readers that Adams had never received a vote of confidence from the House.

It is a fact, not denied, that our executive interfered in this case with the judiciary department, and thereby undoubtedly acted unconstitutionally. It is also, a fact, that Judge Bee considered it of no consequence, whether [Robbins] was or was not an American citizen; and it is also a fact, that in this case he was condemned without the benefit of a trial by jury ... there never was a more disgraceful thing done by any country which had the least claim to independence. If this had not been so considered even by those opposed to republicanism in Congress, can any man of common discernment think that Congress would have dismissed the matter as they did?-If they had approved of the president's conduct, judge Bee's behaviour, and Timothy's impartiality, would they not have agreed to Bayard's motion? Would they not have exculpated our president . . . and would they have dismissed the subject in the manner they did . . ? ? 505

The 1800 election is famous for requiring the House of Representatives to cast 36 ballots to break the tie for President between Republican candidates Jefferson and Burr-the dependence of the Presidency on the House that High Federalists had feared. But the electoral numbers against John Adams were decisive: 73 for Jefferson, 73 for Burr, and 65 for Adams. As Jefferson had

Republican critics offered an unkind opinion of Marshall's personal prospects: "John Marshall used sometimes to brag that he would one day be chosen Vice-President. Believe me, sir, that at this day he could not keep his seat in the event of a new election for Congress. The last election cost him five or six thousand dollars for barbecues; and this was the man who complained of French bribery! Was there ever such another farce?" Letter from a correspondent in Richmond to William Duane, Examiner (Richmond, Va.), reprinted in Salem Gazette (Salem, Mass.), June 20,1800, at 2, col. 2 (castigated by Salem editor as "FOREIGN INCENDIARISM").

504. Aurora (Philadelphia, Pa.), Aug. 22, 1800, at 2, col. 5 (reprinting Newark Centinel of Freedom).

505. Aurora (Philadelphia, Pa), Oct. 2, 1800, at 2, col. 4 (emphasis in original). See also Letter of John Fowler, Member of Congress from the State of Kentucky, To His Constituents, in Aurora (Philadelphia, Pa.), June 9, 1800, at 3, col. 4; also in Carolina Gazette (Charleston, S.C.), July 10, 1800, at 2, col. 4 ("all that could be said in defence of the president ... was urged on the floor of Congress, but it failed, to prove this advice and request was not an unconstitutional interference on the part of the executive, with the judiciary department."); Letter of Virginia Congressman Anthony New to William Latane (Apr. 8, 1800), in 1 CIRCULAR LETTERS OF CONGRESSMEN TO THEIR CONSTITUENTS, 1789-1829, at 194, 196 (Noble E. Cunningham, Jr., ed. 1978); also in Gazette of the United States (Philadelphia, Pa.), May 10, 1800, at 3, col. 1 (motion of approbation in Robbins debate "was withdrawn by the President's friends, as being rather too much to ask even of his devoted majority"). 
predicted, the loss of New York and the split of electors in Pennsylvania were crucial, bringing Jefferson even with Adams. With the count of electors standing 65 to 65, Adams' final hope rested in South Carolina. Despite the pairing of South Carolinian Charles Cotesworth Pinckney as Adams' vice-president and an even split between parties for South Carolina's Congressional seats, the South Carolina legislature chose Republican electors for the Presidency. ${ }^{506}$ John Adams went home, with bitterness, to Quincy.

Following the Federalist defeat in the 1800 election, a number of interesting things happened. In 1801, before he left office, Adams named Judge Bee as the Chief Judge of the newly created Circuit Court for South Carolina; Bee declined the appointment. ${ }^{507}$ In 1810, when admirers of Judge Bee issued a collection of his opinions, they included Marshall's speech in the House and a version of Bee's summary order-but not Judge Bee's extended explanation of his decision, though it was the most famous he was to deliver. ${ }^{508}$ The extradition article of the Jay Treaty was allowed to lapse in 1807, and no other extradition treaty was ratified until the Webster-Ashburton Treaty in $1842 .{ }^{509}$ In the interim, American border states occasionally delivered fugitives back to Canada by use of state police power or informal means, but the federal Executive eschewed any formal power to act upon the law of nations in the absence of Congressional statute. The Republican view was ascendent.

\section{AfTER THE FALL}

To the end of his life, John Adams never forgot the purpose and force of the Republican attack asserting the power of the House. Even years after the event, Adams was unreconciled to Livingston's "lying Villany in his fictitious fabricated Case of a Jonathan Robbins who never existed," 510 the "Terrorism" when "Ned Livingston was threatening me with Impeachment for the murder

506. Cunningham concludes that Adams' break with the High Federalists cannot alone explain the South Carolina vote. See Cunningham, The Election of 1800, in 1 HISTORY OF AMERICAN PRESIDENTIAL ELECTIONS 126-31 (A. Schlesinger, Jr. \& F. Israel eds. 1985); see also South Carolina in the Presidential Election of 1800, 4 AM. HIST. REV. 111, 114 (1899).

507. 2 THE DOCUMENTARY HISTORY OF THE SUPREME COURT OF THE UNITED STATES, 1789-1800: THE JUSTICES ON CIRCUT, 1790-1794, supra note 37, at 103 n.3.

508. See Reports of CASES AdJUdged IN THE District COURT OF SOUTH CAROLINA BY the HoN. THOMAS BEE, supra note 279 , at 266 \& n.*.

509. See Treaty to settle and define the boundaries between the territories of the United States and the possessions of Her Britannic Majesty in North America, for the final suppression of the African Slave Trade, and for the giving up of criminals, fugitive from justice, in certain cases [Webster-Ashburton Treaty], United States-Great Britain, art. 10, 8 Stat. 572, 576, T.S. No. 119 (signed Aug. 9, 1842; ratified Aug. 22, 1842). Even then, legislation to give federal judges "power, jurisdiction and authority" to issue warrants and to determine sufficiency of the evidence in extradition was not enacted until 1848. See An Act for giving Effect to certain Treaty Stipulations between this and foreign Governments, for the Apprehension and delivering up of certain Offenders, 9 Stat. 302 (1848).

510. Letter from John Adams to Thomas Jefferson (May 1, 1812), in THE ADAMS-JEFFERSON LETTERS, supra note 19 , at 300 . 
of Jonathan Robbins."511 Though there was plentiful other cause for losing the 1800 election, Adams came to see that his understanding of Executive power was not shared at large, and certainly, that formal allocation of the treaty power to the President and Senate could not insulate foreign affairs from the mandate of popular politics and the course of popular passions. "Terrors," to use Adams' word, would be excited by both parties to win elections and to discourage certain types of constitutional claims. ${ }^{512}$ Though metaphor can turn brittle, one may see Adams as a second martyr in the tableau. Adams was without any intentional misfeasance in the Robbins affair, yet Adams' excoriation and defeat was desired as constitutional lesson, to dissuade future Executives from acting on-shore without the concurrence of House and jury. "In Adams' fall, we sinned all," the Aurora chided. ${ }^{513}$ The textual Constitution and politics' constitution were worlds apart.

Adams' defeat also held a lesson, we may suppose, for John Marshall in his new office. In scruple at having dared too far in defense of John Adams, or in electoral chastening, Chief Justice Marshall in 1803 places a far different cast on the powers of the Presidency. The Chief Justice's opinion in Marbury v. Madison ${ }^{514}$ is usually read as the Supreme Court's declaration of its power

511. Letter from John Adams to Thomas Jefferson (June 30, 1813), in id. at 346, 348.

512. See id. at 347 :

The real terrors of both Parties have allways been, and now are, The fear that they shall loose the Elections and consequently the Loaves and Fishes; and that their Antagonists will obtain them. Both parties have excited artificial Terrors and if I were summoned as a Witness to say upon Oath, which Party had excited, Machiavillialy, the most terror, and which had really felt the most, I could not give a more sincere Answer, than in the vulgar Style "Put them in a bagg, and shake them, and then see which comes out first."

Adams saw the fault of histrionics in his own party as well as the Republicans:

No party, that ever existed, knew itself so little, or so vainly overrated its own influence and popularity, as ours. None ever understood so ill the causes of its own power, or so wantonly destroyed them. If we had been blessed with common sense, we should not have been overthrown by Philip Freneau, Duane, Callender, Cooper, and Lyon, or their great patron and protector. . . . we have no Americans in America. The federalists have been no more Americans than the anties. Letter from John Adams to Benjamin Stoddert (Mar. 31, 1801), in 9 THE WORKS OF JOHN ADAMS, supra note 193 , at 582 .

513. Aurora (Philadelphia, Pa), June 4, 1800, at 2, col. 2. Aurora publisher William Duane repeated the moral in 1803 in the songbook of THE AMERICAN REPUBLICAN HARMONIST, supra note 369. See Robbins's Lament (set to the tune of The Galley Slave), in id., at 43-44 (emphasis in original) ("alas! by the judge, who my birth-right deny'd, / When for trial by jury, I pray'd, / By the executive power, who advised-he sigh'd, / He sighed, I by these was betray'd. // . . . // To Jamaica far over the turbulent wave, / Where the sun darts its vertical ray, / By executive influence, RoBBINS the brave, / Was a sacrifice, borne away. // In the hands of his foes, a sad victim of state, / As a martyr he yielded his breath; / Ye sons of Columbia, O! think on his fate-/ He resolv'd to have freadom or death."). See also The Duke's Retreat to Braintree (set to the tune of $I$ followed him to Glasgow Town), in id., at 15-17 (emphasis in original) ("JOHN ADAMS was a President, / And fain he would again be; / But Jefferson we chose instead, / And sent the Duke to Braintree. / Tol lol der rol. //... .// Sad thoughts by day, while on the way, / And sleeping he could plain see, / Poor Robbins' sprite on ev'ry night, / He journey'd on to Braintree. / Tol lol der rol. //... .// Of Harper, Pickering, Bee, and Chase, / And colleagues, does complain he, / As cause of all his sad disgrace, / And his retreat to Braintree. / Tol lol der rol. / . . . // One hundred years or more to come, / But yet I would not vain be, / This song may chance again be sung, / Call'd the Duke's retreat to Braintree. / Tol lol der rol.").

514. 5 U.S. (1 Cranch) 137 (1803). 
against the Congress. We may see the more crucial passages of Marbury as those treating the Executive. Marbury is an ambivalent opinion, preserving a strong doctrine of political question. On the facts, Marshall pronounces only upon the ministerial act of delivering a commission of office. Still the language and logic run further, structuring the appointments process within the Executive branch, assessing that a right to office may vest before the President has imagined, pronouncing the exercise of Presidential power to be eminently justiciable when directed against a person's rights of property or liberty. ${ }^{515}$ Marbury may be taken to discourage any extension of unreviewable government powers addressed to the entitlements of men.

By the constitution of the United States, the president is invested with certain important political powers, in the exercise of which he is to use his own discretion, and is accountable only to his country in his political character, and to his own conscience. ... The subjects are political. They respect the nation, not individual rights, and being intrusted to the executive, the decision of the executive is conclusive.

**** *

But where a specific duty is assigned by law, and individual rights depend upon the performance of that duty, it seems equally clear, that the individual who considers himself injured, has a right to resort to the laws of his country for a remedy. ${ }^{516}$

Yet wish to or not, we must learn to read Marshall with open eyes-making sense of his youthful career, when he took a view of Executive power far closer to Hamilton, Adams, and High Federalists than one would ever imagine from his words on the bench.

The Robbins affair carries grave import as well for the law of nations in American jurisprudence. We wonder why the Enlightenment's idea of the law of nature and nations becomes less pronounceable by American jurists as the nineteenth century proceeds - the idea of a mandatory law, deduced from reason as much as from practice, obligatory on all members of a universal community, a jus gentium that may govern internal conduct as well as external relations, a law admired as slowly convergent with a law of reason. The tenuous survival of the natural law of nations is about many things, of course. Romanticism succeeds classicism; will succeeds reason. Historicism sees law as an expression of nationalism and national ethos. The competition for territory and influence may foster a view that law should serve national advantage, not a common interest. Ideological schism concerning revolutionary claims is central. But part of the reason for change in our sources of law is the difficulty posed by democracy, which reinforces positivism by demanding reference to the immediately expressed will of legislators, masking any natural law reference behind 
the psychological act of will. Marshall's defense of John Adams was based on a potentially radical theory of Executive power. In Congressman Marshall's compass, the President can take any measures suggested by the "nature of things" to fulfill his duty to execute the laws. Only by narrowing the notion of what counts as "law" and by limiting the President's ability to enlist agents of his power, can such a power of execution be kept within republican bounds. It would be conceivable to view the President as enjoying inherent Article II authority to execute any perfect obligations under the law of nations-those duties that no polity could properly refuse and that could be the subject of retaliatory sanction. Even imperfect obligations (duties that could not be policed by force) or actions based on comity (acting beyond duty to sustain good relations with foreign interlocutors) might be seen as within the President's authority where legislation had not been exercised. By Marshall's lights, the President might act without any legislative ratification, through executive warrants and commissioners under the law of nations. Marshall's theory of a strong power of execution mandates, at least for a republican, a counterbalancing restriction on what counts as law within the domestic government. The law of nations may be a source of law to fill lacunae and to inform interpretation, but only comfortably in areas where the interpreter already possesses authority by democratic acclamation.

The consequences of this are serious. In our attempts to govern American power in the world, we have been blind to how the narrowing of our ideas of law has so conveniently left us without law when we act upon others. Confining the law of nations to a narrow scope, supposing that it does not impose mandatory duties, is a posture comforting to a democratic republican who worries about Executive power acting at home; the tension is that it leaves action abroad without the pretense of legal constraint. The idea of a law of nations, derived not only from custom and actual consent but from reason, inferences of what a reasonable nation would agree to, may intrigue a neoKantian or a game-theorist, but is not a category of thought extant in international law or American constitutional law. One may see Congress' push to manage foreign relations as reflecting the sense that some law-like norms must underlie policy. Having blinded the Executive to the unwritten law of nations, lest the Presidency draw domestic strength from it through the power of execution, the only alternative to govern foreign action is legislative politics, with its passions and inconsistencies. The push for shared daily management of foreign affairs, reminiscent of Philadelphia's early thought of placing Executive powers in the Senate as much as in a President, finds its roots in a fear of unregulated power, and to understand how Executive power lost its constraints we must in turn see how the natural law of nations met its death as a category of thought.

An equally striking aftermath is the retreat of treaty power before the advancing armies of direct democracy. To be sure, John Marshall and Joseph 
Story would intimate in Marbury and Martin that federal courts should protect their adjudicative jurisdiction against legislative interference. But deference to legislative power was shown by restricting the reach of treaties as rules of decision. In 1829 John Marshall acknowledged in Foster \& Elam $v$. Neilson,,$^{517}$ and again in 1833 in United States v. Percheman, ${ }^{518}$ that some treaties are not self-executing but depend upon legislative implementation. In 1831, Marshall arranged through the artful constructions of Cherokee Nation v. Georgia ${ }^{519}$ to withdraw Article III jurisdiction from the citizens of that "domestic dependent nation," as if he understood that treaty power would not survive another encounter against popular if wholly illiberal sentiment. In Cherokee Tobacco ${ }^{520}$ and The Head Money Cases $^{521}$ the Supreme Court allowed that treaties could be displaced as domestic law by last-in-time statutes-overthrowing the claims of John Jay in Federalist No. 64 and Alexander Hamilton in The Defence No. $38^{522}$ that treaties were sacrosanct and not subject to legislative supersession. Sounding like Jeffersonian judges transported to the late nineteenth century, the Head Money Court rebuffed the claim that the deliberative capacity of the Senate entitled its treaty decisions to be shielded from judgment by the House of Representatives: "Nor is there anything in its essential character, or in the branches of the government by which the treaty is made, which gives it . . . superior sanctity. . . . If there be any difference . . . it would seem to be in favor of an act in which all three of the bodies participate." ${ }^{223}$ By then, the movement for direct election of Senators was in high season; the difference between chambers would be whittled down to term, district size, and small-state disproportion. ${ }^{524}$ With the House frequently entrusted with treaty implementation, representing the public's most recent will, the claim of a special dignity for treaty law receded. Since then, the courts have guarded the sanctity of treaties with a clear statement rule, ${ }^{525}$ but where the popular voice of Congress unequivocally utters its will to disregard treaty promises, then courts comply and treaties yield. One may wonder, in the face of this, whether it would not be sounder to have treaties ratified by both Houses

517. 27 U.S. (2 Pet.) 253 (1829).

518. 32 U.S. (7 Pet.) 51 (1833).

519. 30 U.S. (5 Pet.) I (1831).

520. The Cherokee Tobacco, 78 U.S. (11 Wall.) 616 (1870) (plurality opinion).

521. Edye v. Robertson (The Head Money Cases), 112 U.S. 580, 597-99 (1884). See also Taylor v. Morton, 23 F. Cas. 784, 786 (C.C.D. Mass. 1855) (No. 13,799) (Curtis, Circuit Justice), aff'd, 67 U.S. (2 Black) 481 (1862); Whitney v. Robertson, 124 U.S. 190, 194 (1888).

522. 20 THE PAPERS OF ALEXANDER HAMILTON, supra note 78 , at $22,24,25 \mathrm{n} . *$.

523. The Head Money Cases, 112 U.S. at 599 (Miller, J.).

524. See 1 G. HAYNes, THE Senate of THE UNITED STATES 96-117 (1938); G. Haynes, The ELECTION OF SENATORS 100-20 (1906); ClaRA KERR, THE ORIGIN AND DEVELOPMENT OF THE UNTED STATES SENATE 19-20 (1895); L. ROGERS, THE AMERICAN SENATE (1926).

525. See, e.g., United States v. Palestine Liberation Org., 695 F. Supp. 1456 (S.D.N.Y. 1988) (Palmieri, J.). 
of Congress, so that each House might feel its institutional honor to be more immediately at stake in observance of international pacts. ${ }^{526}$

To the constitutional historian the virulent rhetoric of the Robbins affair leaves the most difficult question. Was there any true danger of constitutional instability? Were the apparitions of monarchy and popular violence summoned by Republican and Federalist editors simply electoral lampoons, or did they represent real fears and actual possibility? In reading the newspapers and correspondence of the times, one has the sense that even the participants weren't sure. Certainly there were catalysts for reaction, and some of these were purged only by chance events. The 1787 Constitution thwarted Hamilton's great energies and ambitions, foreign birth placing the Presidency out of reach; despite his own adventurism, Aaron Burr may have ballasted American politics by ending Hamilton's career in the Weehawken duel in 1804. War with France posed a great danger. If Adams had not sent an additional diplomatic mission to the Directory, open war with the French was probable. This would have allowed High Federalists the license of war emergency, and left Republicans associated in popular mind with a declared enemy. Instead, peace with France was maintained, by the act of statesmanship for which Adams in his usual ill fortune would receive no acclaim, yielding the 1801 treaty. ${ }^{527}$ By war avoidance, Adams reversed the polarity of American politics, and diminished its charge, allowing American Republicanism to avoid association with any foreign enemy. Adams' act of diplomacy was the more striking for its personal cost; Adams lost High Federalist support, and lost the election.

Impressment would make the monocratic British constitution an easy opponent for the next forty years; and movement in early nineteenth century England toward electoral reform and a confined prerogative would drain even the English constitution of the princely dispatch and resolve that High Federalists desired. On the Republican side, Napoleon's ascension from general to consul to emperor served to dampen attraction to the French example. How could one prefer French Republicanism when the real choice was emperor or king in parliament? A nativism for American law and politics became easier to sustain.

A claim of this essay has been that it did not require any overt change in text to alter the tenor of government; one could (and can) attain Federalist or Republican readings of the same seven constitutional articles, with exceedingly different results. A working constitution is recast repeatedly over the interpre-

526. One can pose a Federalist alternative: reviving the view of Jay and Hamilton that treaties are not subject to legislative supersession. To be politically tenable in the modern age, one would have to add a dollop of Madison by distinguishing among types of treaties. The immediate occasion for the Supreme Court's announcement of the last-in-time rule-the violation of a treaty with the Cherokee Nation--might yield surprising allies.

527. Convention of Peace, Commerce, and Navigation, United States-France, 8 Stat. 178, T.S. No. 85 (signed at Paris, Sept. 30, 1800; proclaimed Dec. 21, 1801). 
tive course of decades, and the rhetoric of the Robbins affair had a part in those interpretive choices. How to honor the ethos of a revolutionary past yet manage foreign affairs to advantage is not at all clear, even now. Philip Freneau's poetic victory was to make palpable how less democratic institutions of government had misfired in the event or come close to it. A mediately elected President and an unelected federal judge might take proper account of liberty and a natural right of resistance, as John Marshall argued. But the outcome of the Robbins case seemed to show the fallibility of leaders who had much else on their minds, who could be inclined to balance the right of resistance against the demands of good neighborhood with a foreign partner. For Republicans, only popular institutions, irregular and willful though they might be, could give suitable weight to the claims of a revolutionary origin.

The political uproar at Adams' exercise of Executive power also taught the wisdom of avoiding rhetorical provocation. Adams' actions were read without charity, in part because Adams had made ingenuous remarks on the forms of balance in government in the Defence and Discourses. Adams piously did not realize that free philosophical speculation and practical politics cannot always be combined. Arguments for Executive decision in matters of state would be made with a new sort of humility, working in oblique motion. The flirtations of Missouri v. Holland, ${ }^{528}$ the obiter of Curtiss-Wright, ${ }^{529}$ the hankering after text in Belmont, ${ }^{530}$ Pink, $^{531}$ and Dames \& Moore ${ }^{532}$ (cadenzas on the President's power to receive ambassadors, in ways that would have astonished Madison), ${ }^{533}$ have reflected this lesson of tact. Though one might resort to that "delicate, plenary and exclusive power" 534 of the Presidency when necessity required, it was to be spoken of in hushed tones, shrouded in indirection; the President would gain precedence by his capacity for action and initiative, rather than by de jure claim, politely treating acquiescence as authorization. ${ }^{535}$

For friends of Executive power, an unavoidable lesson of the Robbins affair is that action without legislative approval will lack latitude for error and misjudgment. The missteps that affect citizens should be taken with their recent permission. Another is the necessity of democratic regard, recognizing the

528. 252 U.S. 416 (1920).

529. United States v. Curtiss-Wright Export Corp., 299 U.S. 304 (1936).

530. United States v. Belmont, 301 U.S. 324 (1937).

531. United States v. Pink, 315 U.S. 203 (1942).

532. Dames \& Moore v. Regan, 453 U.S. $654,682-83$ (1981).

533. See U.S. CONST. art. II, § 3. The survival of some portion of the Federalist medel is shown in the twentieth century view that the President's duty to receive ambassadors also imports the unilateral power to establish or break relations with foreign governments, and to enter momentous pacts such as the Litvinov agreement as part of diplomatic recognition. This was not Madison's view. See J. MADISON, Helvidius No. 3, in 15 THE PAPERS OF JAMES MADISON, supra note 57, at 95, 96, 98 ("little if any thing more was intended by the clause, than to provide for a particular mode of communication"; "a right to refuse to acknowledge a new government cannot be implied by the right to refuse a public Minister.").

534. United States v. Curtiss-Wright Export Corp., 299 U.S. at 320.

535. Cf. Dames \& Moore v. Regan, 453 U.S. at 686. 
dignity of ordinary men even where one would decide against their counsel. Presidents would learn to invoke national interest; courts would learn to reify the demands of the law; but the lesson of the 1790's and the Robbins affair was that in American politics one could not trumpet the claim of possessing greater wisdom than the people or their immediate representatives.

Since the nineteenth century, the Robbins affair has been forced into two distinct traditions: cast in polarized light by Monocrat and Jacobin, Federalists and Republicans, Whigs and Democrats, adherents of Executive and Congressional power. The first have celebrated Marshall's claimed vindication of the Presidency before the House of Representatives, perhaps without thinking through the full reach and radical character of Marshall's theory. The latter have pointed to the extra-Congressional storm of popular rhetoric and ridicule that helped bar Adams' re-election; political debacle impeaches delivered opinion, and establishes the opposite as "practical" precedent. To the post-lapsarian critic, Jonathan Robbins and John Adams' closed careers are democratic tell-tale of what may happen should a Monocrat forget America's revolutionary origin and the Constitutional claims of popular voice. ${ }^{536}$

536. Public Record Office materials are Crown copyright, used by permission of the Controller of Her Majesty's Stationery Office. The letters of Pickering and Adams are reproduced by permission of the Massachusetts Historical Society; Gallatin's notes are used by permission of the New-York Historical Society. I appreciate the courtesy of Louis Tucker, Peter Drummey, and Virginia Smith of the Massachusetts Historical Society, Richard Alan Ryerson of the Adams Papers, and Jean Ashton and Margaret Heilbrun of the New-York Historical Society, in permitting me to compare the microfilm editions to the original papers of Pickering, Adams, and Gallatin as required for an accurate text. Original spellings and punctuation have been preserved. The American Antiquarian Society provided the September 3, 1799 Aurora for Figure B. Thanks also to Margaret Durkin of the Yale Law Library, to Paddy Rawlinson and the staff of the Public Record Office, and to the Charleston Library Society and the South Caroliniana Library for references from their fine collections. Ever thanks to my colleagues: Bruce Ackerman, Akhil Amar, Guido Calabresi, Stephen Carter, Willie Fletcher, Harold Koh, Tony Kronman, Kate Stith, Whit Cobb, and members of the Faculty Workshop of Yale Law School and the Faculty Fellowship of the Yale Institution for Social and Policy Studies. 